\title{
TURBELLARIA BRASILEIROS (8)
}

\author{
por Ernesto Marcus
}

\author{
(com 34 estampas)
}

A minha Esposa, Excelentíssima Senhora D. Eveline DU Bors-ReyMond Marcus, e eu, apresentamos, nas páginas seguintes, os resultados dos nossos continuados estudos sôbre Turbelários marinhos colecionados na costa de São Paulo.

Agradecemos à Comissão de Pesquisa Científica da Universidade de São Paulo (Presidente : Sr. Prof. Dr. Ernesto de Souza Campos) o auxílio que nos concedeu para várias estadias no litoral e à Dra. D. Diva Diniz Corrêa a colaboração e companhia nestas, assim como a revisão linguística do manuscrito.

Somos também reconhecidos às Sras. Dra. D. Marta Vannucci e D. Helena Villaça, pelas amostras de areia que a nós trouxeram, e ao Prof. Dr. A. Remane de Kiel, Alemanha, pela chave dos Proseriata copiada do manuscrito de J. Meixner, complementar à obra dêste, de 1938.

\section{Í N D I C E}

Acoela

\begin{tabular}{|c|c|c|}
\hline & & \\
\hline Haploposthia microphoca. & & \\
\hline $\begin{array}{l}\text { Paraproporus xanthus } \\
\text { Childia pansa }\end{array}$ & & \\
\hline Childia pansa . .. & & \\
\hline Kuma brevicauda & & \\
\hline $\begin{array}{l}\text { Mecynostomum tenuissimum } \\
\text { (West.).. }\end{array}$ & & \\
\hline Paraphanostoma westbladi & $\ldots$ & \\
\hline Aphanostoma orphinum & .. & \\
\hline Convoluta divæ! $\quad \ldots$ & & \\
\hline Amphiscolops sargassi $\mathrm{Hy}$ & n... & \\
\hline
\end{tabular}

Macrostomida

Microstomum gabriellæ $\ldots \ldots \quad 21$

Microstomum trichotum .... 24

Microstomum ulum ..... 26

Macrostomum evelinæ Marc. 28

Dolichomacrostomum mortenseni 28

Rhabdocoela

Lurus evelinæ $\quad \ldots . \ldots . . . \quad 33$

Proschizorhynchus atopus... $\quad 34$

Schizorhynchoides martæ $\quad \ldots \quad 37$

Holocoela

Rosmarium evelinæ

Cylindrostoma netsicum
Cylindrostoma ibeenum
Monoophorum tigacum ....
Puzostoma evelinæ .....

Págs.

45

46

49

Seriata

Promonotus erinaceus .... 51

Monocelis tabira..... $\ldots . .54$

Mesoda gabriellæ Marc. $\quad$. 56

$\begin{array}{llll}\text { Necia sopha } & \ldots & \ldots & 57\end{array}$

Peraclistus itaipus ..... 60

Philosyrtis eumeca ... 63

Kata leroda $\quad \ldots \quad \quad \ldots . \quad 65$

Nematoplana asita $\quad \ldots .6 \quad 67$

Tabaota curiosa ... $\quad \ldots . \quad 72$

Polycladida

Adenoplana evelinæ ..... $\quad 76$

Tabela das Latocestidæ... 78

Hoploplana divæ .. ... $\quad 79$

Pseudoceros evelinæ $\quad \ldots . .81$

Cycloporus gabriellæ ...... 89

Larva sexuada de C. gabriellæ. $\quad 91$

Prosthiostomum matarazzoi $\quad 94$

Prosthiostomum gilvum $\quad 98$

Prosthiostomum cynarium $\quad 99$ 


\title{
Ordo : Acoela Uljanin 1870
}

\section{Subordo : Opisthandropora-Abursalia Westblad (1948, p. 52)}

Família : Haploposthiidæe Westblad (ibid.)

\author{
Genus : Haploposthia An der Lan (1936, p. 318-319)
}

Nêste gênero, completamente estudado por Westblad (1945, p. 10, $46 ; 1946$, p. 3, 37), existem três tipos de sexualidade : 1) espécies hermafroditas com zona germinativa mixta difusa ; 2) espécies hermafroditas com testículos e ovários ; 3) uma espécie de sexos separados. Para evitar repetições, damos apenas a chave do primeiro grupo, ao qual a nova espécie do nosso material pertence.

1 Glândulas frontais fracamente desenvolvidas, não atingindo o estatocisto. ... ... ... ...... brunea An der Lan (1936, p. 321)

- Glândulas frontais muito desenvolvidas, atingindo a zona germinativa

2 Corpo cuneiforme, posteriormente alargado ; glândulas rabditógenas numerosas ; com penis cuticularizado.... . . rubra (An der Lan 1936, p. 323)

- Corpo com forma de foca, posteriormente atenuado ; poucas glândulas rabditógenas; sem penis. $\quad . . \quad \ldots \quad \ldots$ microphoca

\section{Haploposthia microphoca, spec. nov. (Fig. 1-2)}

Os vermes medem 0,14 $\mathrm{mm}$. de comprimento, no estado fixado e, com isso, pertencem aos menores Acoela conhecidos. Enquanto vivos, ficaram aquém de $0,3 \mathrm{~mm}$. A forma do corpo lembra, de certo modo, a de uma foca em escala minúscula, sendo roliço, anteriormente cônico-obtuso e atenuado posteriormente. Esta forma discorda da das outras espécies de gênero, que pertencem, todas, a outros biótopos, vivendo ou bentonicamente ou na areia. H. microphoca, a primeira espécie de Haploposthia que nada livremente, entre algas do litoral superior, evidencia-se, pela configuração de gota, adaptada a êste biótopo.

A côr é amarela doirada e condicionada pelas glândulas rabditógenas (r), i. é, de secreção mucosa bacilar, cuja estrutura se modifica na fixação. Estas glândulas são pouco numerosas, mas "muito aprofundadas. Afora a reentrância do órgão frontal (f) e o orifício do aparêlho masculino (t) não se reconhecem outros poros, pois a bôca (b), que é ventral, é muito pequena e apenas marcada pela posição, aí superficial, do endocício (n).

No epicício não se distinguem limites inter-celulares, e os núcleos são pouco numerosos. Por baixo da zona das raízes dos cílios encontram-se alguns grânulos de pigmento, amarelado-acastanhado nos cortes corados com hematoxilina-eosina. São algo mais numerosos na região anterior do corpo, nomeadamente (p) na desembocadura comum (f) das glândulas frontais. Estas são volumosas (g) e atingem as zonas germinativas (o). Além dos grânulos de pigmento, observa-se, no orifício do órgão frontal, certa acumulação de secreção, menos espessa que a de $H$. rubra (Westblad 1945, p. 16). A musculatura cutânea e a do parênquima são fracas. O ectocício é rico em núcleos e menos vacuolizado que nas outras espécies de Haploposthia. O endocício (n), porém, é, como nestas, finamente granuloso e de 
núcleos escassos. O estatocisto (e) situa-se dentro do volumoso cérebro (c), que pertence ao ectocício, não parcialmente ao epicício, como foi descrito de $H$. brunea (An der Lan 1936, p. 304-305). Células sensoriais de Luther (m) vêem-se na extremidade anterior.

Nos dois lados do estatocisto existem dois olhos pretos (Fig. 1), sem cristalino, cujo pigmento não se conservou nos cortes. Não ocorrem olhos nas outras espécies do gênero. H. microphoca, habitante do litoral superior, revela-se, pelos olhos, mais uma vez especialmente adaptada. Segundo Westblad (1948, p. 25), somente espécies litorais dos Acoela possuem olhos.

As gônadas dispõem-se difusamente nos dois lados do corpo, entre as grandes glândulas rabditógenas (r). Ovogônias e espermatogônias não se diferenciam. As zonas germinativas (o) são principalmente dorso-laterais. Orgãos auxiliares femininos faltam, como sempre, em Haploposthia. A via eferente masculina corresponde, aproximadamente, ao tipo de $H$. viridis, desenhado por An der Lan (1936, f. 12 na p. 311) e, com pormenores, por Westblad (1945, f. 9 B, no texto da p. 23). O ectocício concentra-se, assumindo estrutura fibrilar, e forma uma vesícula seminal simples (s) que desemboca no átrio masculino tubuloso (a). Algumas fibras musculares anelares circundam o átrio que é revestido por cílios. Bastonetes cuticulares, pouco numerosos, ressaltam-se na parede do átrio.

Ocorrência : Ilha de São Sebastião, entre algas do litoral superior ; 2 exemplares maduros em novembro de 1949.

\section{Genus : Paraproporus Westblad $(1945$, p. 8, 46)}

No nosso material há uma espécie dos Opisthandropora-Abursalia, caracterizada como pertencente às Haploposthiidæ pela ausência da faringe que ocorre nas Proporidæ e Diopisthoporidæ. Orgão copulador impar, com bastonetes cuticulares, existe, dentro da família indicada, somente em Paraproporus. A única espécie dêste gênero, até agora conhecida, é avermelhada-violeta, tem glândulas frontais não concentradas e ovos de até $0,15 \mathrm{~mm}$. de diâmetro. $P$ xanthus, a nova espécie, apresenta dimensões semelhantes do corpo, mas o diâmetro dos ovócitos não ultrapassa 0,05 mm. ; as glândulas frontais formam um órgão frontal, e a côr é amarelada. Outros distintivos, de menor importância, serão mencionados na diagnose seguinte.

\section{Paraproporus xanthus, spec. nov. (Fig. 3-5)}

Os vermes opacos teem o corpo ventralmente achatado, alongado e atenuado para trás. Acusam $0,3 \mathrm{~mm}$. de comprimento, nos cortes. A côr é amarelada e condicionada por grânulos situados no epicícioł(h). Nêste reconhecem-se os territórios das células em cortes tangenciais (Fig. 4). As células epiciciais diferem no seu conteúdo de grânulos e são, por isso, ora mais claras, ora"mais escuras, formando um mosáico. Possivelmente, cresce a quantidade de pigmento com a idade das células, cuja substituição periódica acontece normalmente. Glândulas (g), de secreção mucosa, atravessam o epicício.

As glândulas frontais (f), aprofundadas até à região do cérebro (c), desembocam em comum, com poro terminal, constituindo, destarte, um 
órgão frontal. A musculatura é melhor desenvolvida que em $P$. rubescens, tanto a cutânea, anelar (m) e longitudinal (l), quanto a parenquimática, dorso-ventral (k). O comprimento dos ćlios é de 4 micra ; o do epicício, inclusive os músculos cutâneos, de 8,5 micra, medidos no dorso, ao nível da bôca (b). O ectocício (j) forma, como em rubescens, uma camada estreita aposta ao epicício, mas é nítido também na região posterior do verme (Fig. 5). A maior parte do corpo é ocupada pelo endocício (i), atravessado pelos músculos parenquimáticos, por pontes plasmáticas, e contendo Diatomáceas (d).

A bôca (b), que é provida de músculos dorso-ventrais (k), situa-se um pouco anteriormente ao meio do ventre. O estatocisto (e), de $0,012 \mathrm{~mm}$. de diâmetro, é circundado pelo cérebro (c), em cuja proximidade células sensoriais de Luther são reconheciveis.

As gônadas são impares. O ovário é pouco volumoso, acusando os ovócitos mais crescidos (o) diâmetro de $0,05 \mathrm{~mm}$. São envolvidos por baixas células foliculares. $\mathrm{O}$ testículo (t) compõe-se de pequenos folículos, apostos ao ectocício. Os espermatozóides filiformes reunem-se na vesícula seminal (s) de 12,5 micra, ao comprido. Ao longo do átrio masculino (a), de comprimento de 19 micra, dispõem-se os bastonetes cuticulares do penis (p). O conjunto dos bastonetes lembra um guarda-chuva incompletamente fechado. O poro masculino é terminal.

Ocorrência : Ilha de São Sebastião, no lodo, em ca. de $5 \mathrm{~m}$. de profundidade; 12 exemplares em novembro de 1949.

O biótopo em que $P$ xanthus foi encontrado corresponde, ao que parece, ao sueco de $P$. rubescens, na costa do Skagerak ("verwesender Detritusboden"). Provavelmente, ocorre também $P$. rubescens no lodo da costa da ilha de São Sebastião. Do material aí colhido com a draga-trenó, segundo Mortensen (1925), foram isolados alguns exemplares rosáceo-roxos, dos quais apenas um foi re-encontrado nos tubinhos de transporte. Os cortes dêste verme mostram um ovócito grande e glândulas frontais difusas. Mas, visto que a região caudal é defeituosa, e o epicício apresenta territórios celulares separados, hesitamos ainda em assinalar $P$. rubescens Westbl. como elemento da fauna brasileira.

\section{Genus : Childia Graff (1911, p. 23-24)}

\section{Childia pansa, spec. nov. (Figs. 8-9)}

O corpo do verme vivente, ligeiramente comprimido, apresenta-se largamente arredondado, na região anterior, e bicúspide na extremidade posterior, conforme aos dois órgãos copulatórios. O comprimento é de 0,625 $\mathrm{mm}$., no estado vivente, não comprimido ; a largura do verme ligeiramente comprimido é de $0,4 \mathrm{~mm}$. A extremidade anterior pode enrolar-se ventralmente. $\mathrm{O}$ animal é incolor ; o estatocisto (e) situa-se no fim do primeiro quinto do corpo. A bôca (b) encontra-se um pouco atrás do meio do ventre. Este é ligeiramente côncavo, na região anterior; o dorso é convexo. A natação procede uniformemente, sem interrupção por saltos.

Os ćlios locomotores são de 6 micra, ao comprido, na parte anterior, e de 8-9 micra na posterior. Os núcleos do epicício (h) são aprofundados no corpo inteiro ; os territórios celulares reconhecem-se, algumas vezes, alusi- 
vamente, nos cortes tangenciais. Glândulas cutâneas (g) são muito escassas, ocorrendo esporádicas na face ventral. Westblad (1945, p. 32) assinalou diferença topográfica das glândulas mucosas em Ch. groenlandica (Lev.) da baía finlandeza e da costa escandinava ocidental, mas nos dois materiais, estas glândulas são ricamente desenvolvidas. Um órgão frontal falta. Mesmo um único exemplar vivente, comprimido, e mais ainda a série de cortes teriam evidenciado a desembocadura comum das glândulas frontais, se existisse, como em Ch. groenlandica (Graff 1911, t. 2 f. 5 ; Luther 1912, f. 3 no texto da p. 11 ; Westblad 1945, f. 16 B no texto da p. 33). A presença de glândulas frontais avulsas, na espécie atual, não pode ser excluida, pois parece imaginável que, por acaso, não se tingiram, na única série de cortes disponível. Seguramente, porém, inexistem na forma concentrada de um órgão frontal.

A musculatura corresponde à de Ch. groenlandica, descrita por Luther (1912, p. 7). São nítidas as fibras longitudinais externas, as anelares, dispostas em vários planos, e as longitudinais internas (m) que não continuam no dorso. Outros músculos são os retratores da extremidade anterior, que saem dos músculos cutâneos ventrais, as fibras dorso-ventrais (k), frequentes nos dois lados do plano mediano, e os músculos bucais, anelares e radiais.

$\mathrm{O}$ ectocício (j) coere, em parte, com a camada dos núcleos epiciciais, em parte, é vacuolizado. Vacúolos separam ainda o ectocício do endocício (i), que contém pequenas Diatomáceas e é igualmente vacuolizado. A bôca (b), marcada pelos divaricadores radiais no verme vivente (Fig. 8), é inconspícua nos cortes (Fig. 9). Aí é indicada por ligeira reentrância do integumento, interrupção dos núcleos do epicício e pelas fibras esfinctéricas.

O cérebro (c) parece-se, evidentemente, com o de Ch. groenlandica (Westblad 1945, f. 15 no texto da p. 32), mas os cortes sagitais não se prestam para o estudo pormenorizado. O estatocisto (e) é formado pela cápsula nucleada e a célula formadora do estatolito. $O$ órgão post-cerebral, que Westblad viu em muitas séries da espécie setentrional, falta na nossa, mas ainda não pode ser considerado como seguramente ausente na espécie atual. Dentro do integumento anterior e por baixo dêste observam-se células flageladas tácteis (d; “Tastgeisselzellen"), cujos citosomas são aprofundados (Luther 1912, p. 9).

Os testículos ( $\mathrm{t}$ ) são dorso-laterais e começam ao nível do cérebro. Ao lado e atrás das espermatogônias dispõem-se os vários estádios da espermatogênese. De cada lado, corre um trato de espermatozóides para as vesículas seminais (s), não completamente esféricas, devido a um achatamento caudal. A estrutura do penis é a mesma como em Ch. groenlandica (Westblad 1945, p. 34-37). O estilete (p), de 0,045 mm. ao comprido (groenlandica : $0,068 \mathrm{~mm}$., Graff 1911, p. 23), compõe-se de fibras cuticulares que circundam o duto ejaculatório. O átrio masculino (r) que Westblad chama de "Penisscheide" é musculoso. As glândulas atriais (a), ectais, vistas por Luther (1912, f. 3, dr., no texto da p. 11), não por Westblad (l. c., p. 37), re-encontram-se na espécie aqui em mãos.

Os ovários (o) apresentam o sinal disjuntivo principal entre Ch. groenlandica e Ch. pansa. As descrições e figuras de groenlandica, publicadas por Graff, Luther e Westblad concordam quanto à posição das zonas germina- 
tivas ováricas, pouco atrás do cérebro. Em $C h$. pansa, porém, os ovários começam ao nível da bôca. O espécime presente carece de ovócitos completamente crescidos, mas isto não invalida a diferença mencionada. As zonas germinativas de pansa aproximam-se à linha mediana (Fig. 8,o) ; as séries dos ovócitos divergem mais para os lados.

Ocorrência : No lodo do canal de Bertioga, perto de Santos ; 1 exemplar, em outubro de 1949. A salinidade da localidade oscila muito, devido aos afluentes de água doce dos manguezais adjacentes. Durante as horas da enchente penetra a água do mar; durante a vasante, a água torna-se salobra.

\section{Discussão de Childia pansa}

A nova espécie distingue-se de $C h$. groenlandica (Lev.) pela ausência de um órgão frontal, pela escassêz de glândulas cutâneas e pela posição posterior dos ovários, cujas zonas germinativas se situam ao nível da bôca. Foram unicamente êstes caracteres morfológicos que obrigaram à separação específica do material brasileiro. Razões zoogeográficas não são admissíveis na sistematização dos Acoela. Depois de ter Meixner (1925, p. 333 nota) reunido as espécies de Woods Hole (spinosa Graff) e da Finlândia (baltica Luther) com a da Groenlândia, esta foi encontrada não sómente no Atlântico setentrional, mas também na Adria (Steinböck 1933, p. 4).

O canal de Bertioga, até agora a única localidade, em que $C h$. pansa foi verificada, constitue um biótopo muito semelhante aos da costa ocidental da Escandinávia, nos quais Westblad (1945, p. 31, 52) obteve Ch. groenlandica: Reetrâncias rasas do mar, com fundo de detrito ("Mudder"), frequentemente com cheiro de gás sulfídrico.

\section{Genus : Kuma, gen. nov.}

Haploposthiidæ com grandes glândulas frontais, átrio masculino curto, sem penis ou cuticularização atrial. Ovários pares, ventrais. Epicício com núcleos nitidamente aprofundados em toda a região anterior do corpo.

Tipo do gênero: Kuma brevicauda, spec. nov.

A posição quasi terminal do poro masculino (Fig. 12,q) e a ausência de uma bursa identificam os vermes presentes como Opisthandropora-Abursalia. Não havendo faringe, pertencem às Haploposthiidæ. O gênero Haploposthia, com glândulas rabditógenas coloríficas, não pode abranger a nova espécie. Tão pouco Paranaperus, com penis e átrio espaçoso ; Paraproporus, com bastonetes peniais, ou Childia, com dois órgãos copulatórios masculinos. Do gênero Afronta, o único representante, A. aurantiaca Hyman (1944), é grande $(2 \mathrm{~mm}$.), alaranjada com manchas acastanhadas, tem rabditos, estatocisto tripartido, fusiforme, testículos situados anteriormente aos ovários e glândulas frontais indistintas, possivelmente ausentes. Impõe-se, com isso, a introdução de um novo gênero.

$\mathrm{O}$ aprofundamento pronunciado dos núcleos epiciciais, em quasi toda a metade anterior do corpo, foi mencionado na diagnose de Kuma. Não é, porém, sinal disjuntivo importante. Segundo Westblad (1948, p. 13, 16), os núcleos do epicício da extremidade anterior são mais ou menos aprofundados nos Acoela em geral. Apenas a extensão da região do aprofundamento em Kuma parece significativa. Por outro lado, são os núcleos de outro gênero 
das Haploposthiidæ, Childia, aprofundados no corpo inteiro (Luther 1912, p. 5). Dá-se o mesmo, dentro dos Proandropora-Bursalia, em Paraphanostoma (Westblad 1942, p. 14). Em outro representante das Convolutidæ, Amphiscolops sargassi Hym., os núcleos são aprofundados na maior parte do corpo (veja p. 19).

\section{Kuma brevicauda, spec. nov. (Figs. 10-13)}

Os pequenos vermes cilíndricos, incolores, não mostram, no seu aspecto externo (Fig. 10), sinais dignos de nota, afora o orifício principal das glândulas frontais (f), o estatocisto (e) e o endocício da região caudal, vacuolizado (j). Animais jovens, de $0,1 \mathrm{~mm}$., ao comprido, nadam livremente ; os adultos, de longura de $0,35 \mathrm{~mm}$. e diâmetro de $0,06-0,07 \mathrm{~mm}$. (no estado vivente), deslizam sôbre o substrato, sem pular ou aderir aos grãos de areia. A largura é aproximadamente a mesma em todo o corpo. Também as extremidades anterior e posterior apresentam-se do mesmo modo arredondadas. Os cílios (3-4 micra) batem sincronicamente em linhas espirais (Fig. 10). Os cílios anteriores são os mais compridos ; os posteriores, os mais curtos.

$\mathrm{O}$ epicício (Fig. 13) é tênue e orlado pela camada das peças basilares (d) dos cílios ("Cilienfussstücke"), seguida pelos grânulos basilares (z) dos mesmos. O epitélio epicicial (p) mostra membrana basilar fina. Os músculos cutâneos anelares (m) e longitudinais( $\mathrm{y}$ ) dispõem-se como na maioria dos Acoela. Do nível da bôca (b) para diante, os núcleos (w) do epicício são aprofundados, apondo-se, entalmente, à musculatura cutânea longitudinal (y). Na região post-oral do corpo, êstes núcleos são intra-epiteliais. Glândulas de secreção mucosa $(\mathrm{u})$, que ocorrem em pequeno número, aprofundam-se mais ainda que os núcleos epiciciais da parte anterior. Além destas glândulas, destaca-se o grupo volumoso, não completamente concentrado, das glândulas frontais (f). Desembocam no centro da extremidade anterior e na região vizinha (Fig. 12). A altura do integumento, medida das pontas dos cílios até aos núcleos aprofundados, é de 8,5 micra. Rabditos não existem. A musculatura parenquimática (h) atravessa o endocício (i) com numerosas fibras dorso-ventrais. O ectocício $(\mathrm{k})$ forma uma camada pouco profunda, mas rica em núcleos.

O cérebro (c), situado no ectocício, compõe-se de dois pares de gânglios, o par superior, visível nas Fig. 11-12, e o inferior. Vários nervos anteriores saem do cérebro e, pelo menos, um de cada lado (n), que corre para trás. O estatocisto (e), de diâmetro de 12 micra, contém um núcleo do estatolito e dois, da cápsula. Olhos não ocorrem, nem células sensoriais distintas.

A bôca abre-se no fundo de uma reentrância provida de cílios compridos e situa-se um pouco anteriormente ao meio da face ventral. Os divaricadores bucais (g) são mais fortes que os constrictores, em conformidade com as necessidades funcionais. $O$ endocício (i), de núcleos somente periféricos, abriga Diatomáceas e Ciliados e deixa livre (j) a região caudal do verme.

Os testículos ( $\mathrm{t}$ ) dispõem-se dorso-lateralmente, no último terço do corpo. Os feixes de espermatozóides filiformes descem nos lados e formam dois tratos' (r) que convergem ventralmente para a vesícula seminal mediana (s). Esta comunica-se com o átrio masculino bulboso, (a) que é curto e revestido por células altas. O poro masculino (q) encontra-se terminalmente, aproximado ao ventre. 
Os ovários (o) são látero-ventrais, ocupando o nível entre a bôca e os testículos. O tamanho dos ovócitos aumenta de diante para trás. O material não contém ovócitos completamente crescidos.

Ocorrência: Cananea, ca. de $200 \mathrm{~km}$. ao sudoeste de Santos, em areia lodosa. A salinidade da água é inferior à do mar aberto. Da fauna acompanhadora destacaram-se Schizorhynchoides martae (Fig. 61-66), Gastrotricha Macrodasyoidea e o Tardígrado Batillipes pennaki Marc. A maioria dos vermes aquí descritos achou-se imatura, em agosto de 1949. Os animais mantiveram-se durante várias semanas no aquário não arejado.

\section{Subordo : Proandropora-Bursalia Westblad (1948, p. 52, 57)}

\section{Família : Convolutidæ Graff $(1905$, p. 4, 10)}

\section{Genus : Mecynostomum Van Beneden (1870, p. 18); Westblad (1948, p. 57)}

\section{Mecynostomum tenuissimum (Westbl.) (Figs. 14-15)}

Aphanostoma tenuissimum Westblad 1946, p. 41 f. 8, 29.

Os vermes, que são incolores e transparentes, atingem, quando completamente estendidos, comprimento de $1 \mathrm{~mm}$. No material escandinavo e no nosso, ocorrem natação livre, correr por meio dos cílios ventrais e fixação periódica com a terminação caudal do pedúnculo posterior $(0,3 \mathrm{~mm}$.). A extremidade anterior é largamente arredondada e côncava no meio da face ventral. Estereocílios (e) são escassamente distribuidos nos bordos do corpo (Fig. 14).

Os núcleos (n) do epicício são raros e de posição normal, intraepitelial, nas regiões média e posterior do verme ; na parte anterior, aproximadamente até ao nível da bôca (b), são mais numerosos e aprofundados. Nêste pormenor, o material brasileiro difere do nórdico, em cuja figura 8 se reconhece um núcleo intra-epitelial no epicício da região pré-oral. Glândulas cutâneas (g), de secreção mucosa, são escassas ; nos espécimes escandinavos não existem. Possivelmente são glandulares e grudadoras as células (x) que formam o espessamento no ectocício caudal. Rabditos faltam. O ectocício (k) abrange uma camada periférica, rica em células e outra, central, extensa, que é vacuolizada. As glândulas frontais (f) destacam-se mais do que no material sueco e norueguês, formando um cône distinto, embora pouco profundo. Os retratores da região posterior (hrm da figura 8 de Westblad) não conseguimos vêr no material atual que apresenta, aí, músculos dorso-ventrais (h). Os dois gânglios do cérebro (c) circundam o estatocisto $(\mathrm{y})$.

O endocício (i) é nitidamente demarcado e contém Diatomáceas (d). A bôca (b) pertence ao quarto anterior do corpo e destaca-se pela reentrância fortemente ciliada do integumento. O epicício do tubo oral pertence ainda à região, cujos núcleos são aprofundados.

As zonas germinativas dos ovários (o), começam, aproximadamente, ao nível do estatocisto (y) e ventralmente a êste. Os ovócitos mais crescidos são contíguos com a vesícula seminal (s). Bursa seminal não existe, como em $M$. macrospiriferum Westbl. e $M$. agile Jensen $(1878$, p. $31=$ 
Aphanostoma rhomboides Westblad 1946, p. 39 ; 1948, p. 2). Massas difusas de espermatozóides no ectocício atrás dos ovários não observámos. A vesícula seminal (s) é volumosa e abriga o penis musculoso (p), introvertido na vesícula. Glândulas cianófilas ocorrem, como no material escandinavo, ao redor do orifício masculino. Os testículos (t) são laterais, post-cerebrais e dorsais em relação aos ovários.

Ocorrência : Ilha de São Sebastião, no lodo, em ca. de $5 \mathrm{~mm}$. de profundidade ; 6 exemplares em novembro de 1949 ; muitos em junho de 1950.

As glândulas cutâneas mucosas e as frontais são, no material brasileiro, mais desenvolvidas que no escandinavo; os retratores caudais são inconspícuos ou ausentes, e os núcleos epiciciais da região pré-oral são aprofundados. Estes pormenores, porém, não justificam, por enquanto, a denominação de uma forma especial.

\section{Genus : Paraphanostoma Westblad (1942, p. 11)}

Como no gênero precedente, a bursa carece de apêndice musculoso (Aphanostoma) ou de palheta cuticularizada (Convoluta). Distingue-se de Mecynostomum pelo aprofundamento dos núcleos do epicício e pela inversão das camadas da musculatura cutânea, cujas fibras longitudinais são externas ; as anelares, internas.

Conforme a presença ou ausência de vesícula seminal musculosa e de duto espermático, dois grupos de espécies de Paraphanostoma podem ser separados. A nova espécie, denominada em honra de Dr. Einar Westblad, pertence ao primeiro. Por isso, tem de ser comparada, principalmente, com o tipo do gênero, $P$. macroposthium (Steinböck 1931, p. 4) e com $P$. brachyposthium Westblad (1942, p. 42). Da última espécie (3-4 mm., ao comprido) difere westbladi pelo tamanho $(1,5 \mathrm{~mm}$.) menor, pela posição do poro feminino (v) menos distante da bôca (b) que do poro masculino (r), em contraste com a equidistante de brachyposthium, e pela maior aproximação do poro masculino à extremidade caudal. A distância iguala a um décimo do comprimento do corpo, em westbladi; a um oitavo, em brachyposthium.

$P$. macroposthium, cujo tamanho total concorda com o de westbladi, distingue-se dêste pelo apêndice posterior da bursa, pelo comprimento maior dos bastonetes peniais, e pela posição sub-terminal do poro masculino. O cérebro de macroposthium e brachyposthium, embora não especialmente descrito, deve parecer-se com o tipo fundamental do gênero (Westblad 1942 , p. 23), a ser resumido na diagnose seguinte. P. westbladi possue cérebro completamente diferente. Finalmente, logo singularizam-se os cortes de westbladi pelos núcleos grandes de todos os tecidos. Geralmente, acusam diâmetro de 8 micra e são escassamente distribuidos. Nas outras espécies do gênero e, entre estas, em macroposthium e brachyposthium, os núcleos são menores e mais numerosos. Se, p. e., $P$ macroposthium possuisse núcleos tão volumosos quão westbladi, deveriam ser de $2 \mathrm{~mm}$. na figura 2 da estampa 1 de Westblad (1942). O grande número de cromosomas, ca. de 40, contáveis nas divisões das espermatogônias, corresponde ao volume dos núcleos, sendo 20-30 os números normais dos poucos Acoela da lista de Ruebush (1938, p. 322). Em Aphanostoma orphinum há sómente 8 cromosomas, na fase diplóide. 


\section{Paraphanostoma westbladi, spec. nov. (Figs. 16-18)}

Os vermes são cilíndricos, incolores e anteriormente cuspidatos. O tamanho não ultrapassa ca. de $1,5 \mathrm{~mm}$., no estado vivente. Nos maiores cortes que obtivemos, o verme é de $1,025 \mathrm{~mm}$., ao comprido, e de largura de $0,22 \mathrm{~mm}$. A natação procede uniformemente.

Os cílios locomotores são curtos e densos ; as fibras musculares cutâneas, bem desenvolvidas. A disposição externa dos músculos longitudinais (m) e a interna dos anelares (n) já foi mencionada. O estrato dos núcleos aprofundados (k) do epicício (h) passa sem limite ao parênquima do ectocício (j). Também cortes tangenciais não mostram células separadas do epicício. O endocício é pobre em núcleos. A musculatura dorso-ventral é fraca, e os músculos longitudinais (Westblad 1942, p. 17) e transversais (p. 19) de $P$. brachyposthium faltam. Como nas outras espécies do gênero (ibid., p. 16), as glândulas cutâneas mucosas (g) são ricamente desenvolvidas no dorso. Ventralmente, são numerosas apenas na região anterior ; no meio e posteriormente são, no ventre, escassas. Das glândulas frontais (f) reunem-se os dutos de algumas, mas a maioria desemboca isoladamente, no bordo anterior. A bôca (b) situa-se no meio da face ventral, no fundo de uma pequena concavidade.

O cérebro (c) discorda do tipo pouco diferenciado descrito por Westblad (1942, p. 23). Nas espécies $P$. crassum e $P$. submaculatum, pesquisadas pormenorizadamente, existe cérebro em forma de ponte ("brückenförmiges Gehirn", id. 1948, p. 23). As células nervosas acumulam-se atrás do estatocisto, de onde se estendem, de cada lado, dorsal e anteriormente. $O$ cérebro de $P$. westbladi, porém, compõe-se de 2 pares de gânglios, os internos ou dorsais, situados mais para diante, e os externos ou ventrais, situados mais para trás. Forma-se, dêste modo, um anel, póstero-ventralmente fechado apenas pela comissura dos gânglios externos. Isto é o tipo do cerebro de Anaperus tvaerminnensis (Luther 1912, p. 29 ; Westblad 1948, f. 3 B no texto da p. 24). O estatocisto (e), de diâmetro de 0,02 $\mathrm{mm}$., apõe-se ao bordo caudal da comissura entre os gânglios internos.

Os testículos são folículos látero-dorsais que começam ao nível do estatocisto. O diâmetro dos núcleos das espermatogônias (l) é de 10-12 micra. Os tratos (t) dos espermatozóides reunem-se na vesícula seminal (s), que se parece com a de P. macroposthium (Westblad 1942, p. 33 f. 17 no texto). Re-encontram-se o epitélio e os músculos (d) da vesícula, como também o esfíncter (x). Os bastonetes cuticulares (p), que constituem o penis, são de 0,13-0,16 mm., ao comprido. As células circunjacentes (a) são, segundo Westblad (p. 34), glandulares, provavelmente, grânulo-secretoras. $\mathrm{O}$ orifício masculino $(\mathrm{r})$ é um pouco rostral em relação à extremidade caudal (q) do átrio masculino e comunica-se com a parte ental, aproximadamente horizontal, do átrio, por um fino canal quasi vertical.

Os ovários são látero-ventrais e começam pouco antes da bôca. Entre os ovócitos (o) e ao redor dêles encontram-se células foliculares (i). Como em macroposthium e brachyposthium, e em oposição à maioria das espécies de Paraphanostoma, o núcleo dos ovócitos contém 3-4 nucléolos. Os ovócitos mais crescidos, ainda providos de folículo, são volumosos, p. e., de 0,1 mm., ao comprido (extensão ântero-posterior) e de altura (dorso-ventral) de 0,16 $\mathrm{mm}$. $P$. brachyposthium possue ovócitos relativamente pequenos (Westblad 
1942, p. 27). O poro feminino (v) aproxima-se mais à bôca (b) do que ao poro masculino (r), como em macroposthium. O átrio feminino (w) é de estrutura esponjosa, vacuolizada, e continua, para dentro, com uma vesícula epitelial, encurvada para diante, a bursa $(u)$. Nesta vêem-se espérmios, como ocorrem (y) também em um vacúolo do endocício atrás do ovócito (o) mais crescido. Células enfileiradas formam o duto espermático (z) que sáe da constrição entre átrio e bursa. Esta inserção do duto difere da exclusivamente bursal em macroposthium e brachyposthium. Tão pouco quão nestas espécies (Westblad 1946, p. 30), o duto espermático de $P$. westbladi mostra um lume nos cortes.

Ocorrência : Ilha das Palmas, baía de Santos ; entre algas, em outubro de 1946. Ilha de São Sebastião; entre algas do litoral superior (janeiro de 1948) e no lodo, em ca. de $5 \mathrm{~m}$. de profundidade (novembro de 1949). No total, 6 espécimes. 0 material de outubro achou-se só masculinamente maduro; o de novembro e janeiro, também femininamente.

\section{Genus : Aphanostoma Örsted $(1845$, p.' 417)}

O gênero abrange, na definição atual (Westblad 1946, p. 2, 29, 50 ; 1948 , p. 2, 57), duas espécies da família Convolutidæ, providas de vesículas coloríficas ectociciais e de bursa com apêndice musculoso, mas sem palheta cuticular.

A título de ensáio, acrescentamos aquí uma espécie, cujos caracteres não concordam com os supracitados, mas apenas se aproximam dêles : As. vesículas coloríficas existem, mas são epiciciais e o apêndice da bursa delimita-se desta apenas por um esfíncter.

A estrutura da comunicação entre bursa e ovário da nova espécie apresenta-se mais diferenciada do que em Mecynostomum e menos complicada que em Convoluta. Da alternativa, incorporação em Aphanostoma ou introdução de um novo gênero, preferimos a primeira possibilidade, porque dispomos somente de um único exemplar maduro.

\section{Aphanostoma orphinum, spee. nov. (Figs. 19-20)}

$\mathrm{O}$ verme acastanhado tirante a oliváceo, de côr semelhante à das algas que habita, é de forma cilíndrica, com ligeira diminuição do diâmetro para diante e para trás. A largura máxima encontra-se aproximadamente no meio do corpo. O comprimento do exemplar fixado é de $0,3 \mathrm{~mm}$. ; grossura, de $0,09 \mathrm{~mm}$. A bôca (b) situa-se no meio do ventre.

A longura dos cílios é de 3 micra; a das peças basilares dêles, de 1 micron. Outros 9 micra cabem ao epicício (h) juntamente com a musculatura cutânea $(\mathrm{m})$. Os núcleos epiciciais são intra-epiteliais no corpo inteiro. $\mathrm{Na}$ região anterior, são especialmente numerosas as vesículas (v) que contêm, no verme vivente, a substância colorífica. A altura das vesículas pode igualar à do epicício ; muitas delas, porém, deixam a base do epicício livre e, com isso, também, os núcleos epiciciais ; acusando assim as vesículas a altura de ca. de 7 micra. Todo o integumento do corpo é rico em glândulas (g) de secreção mucosa, cujos núcleos se situam no ectocício (j). Este último forma uma camada bem estreita. Os músculos cutâneos longitudinais condicionam a disposição enfileirada das glândulas cutâneas e desta provém o desenho claro, estrelado, na região anterior do verme (Fig. 19). 
As glândulas frontais (f) reunem os seus dutos ao nível do estatocisto (e) e desembocam no meio do bordo anterior. Os citosomas do órgão frontal formam um pacote compácto, no plano mediano; de cada lado, notam-se um lóbulo dorsal e outro ventral, entre os quais os testículos (t) se intercalam. Os lóbulos dorsais atingem, para trás, as zonas germinativas dos ovários (o). A musculatura parenquimática é fraca. O estatocisto (e) situa-se atrás do cérebro (c) que é atravessado pelos dutos das glândulas frontais (f). O endocício (i) é indistintamente delimitado e pobre em núcleos ; torna-se superficial na bôca (b).

Os testículos ( $\mathrm{t}$ ) são laterais e aproximadamente equidistantes do dorso e do ventre. $\mathrm{O}$ início dêles, entre os lóbulos dorsal e ventral do órgão frontal, já foi mencionado. $\mathrm{O}$ diâmetro dos núcleos das espermatogônias é de 8 micra ; o mesmo das células somáticas não ultrapassa 3,5 micra. Nas divisões das espermatogônias reconhecem-se 8 cromosomas. A vesícula seminal (s) delimita-se bem contra o parênquima, e a parede dela é grossa. Orgão copulatório masculino (penis) inexiste. A vesícula comunica-se abertamente com o tubo que representa o átrio masculino (d), por sua vez ligado ao átrio genital comum (a), igualmente tubular. O poro genital (p) é ventral, e mais perto da bôca (b), que da extremidade caudal.

Os ovários (o) são dorsais e, em relação aos testículos, mediais. As zonas germinativas confinam, como foi dito, com os lóbulos dorsais do órgão frontal. Os ovos maduros atingem o nível do poro genital. São tão volumosos que preenchem todo o espaço entre as camadas dorsal e ventral do ectocício (j). A bursa (q) sáe do átrio comum, anteriormente à vesícula seminal (s). A parede interna da bursa é engrossada. Constitue êste espessamento o apêndice bursal (r). A direção mais dorsal que rostral dêste parece condicionada pelo volume colossal do ovo maduro. Entre o lume da bursa e o apêndice existe um esfíncter formado por várias fibras, cujos mioblastos se dispõem na periferia do apêndice.

Ocorrência: Ilha de São Sebastião, entre Sargassum stenophyllum, crescido nas rochas do litoral superior. Além de vários exemplares imaturos, não registrados, foi obtido um espécime maduro, em novembro de 1949.

\section{Discussão de Aphanostoma orphinum}

A phanostoma diversicolor Örst. distingue-se do A. orphinum pela separação dos orifícios masculino e feminino e pela presença de um penis protráctil. A. virescens Örst. apresenta átrio genital comum, mas êste é uma fenda transversal (Steinböck 1931, p. 7), não um tubo. Também A. virescens é provido de um penis (Jensen 1878, t. 1 f. 6) e, além disso, de apéndice bursal muito volumoso, até com acúleos cuticulares.

A forma do corpo das duas espécies de Örsted não se parece com a da espécie atual, e a substância colorífica delas é, como foi dito, ectocicial, não epicicial. Com isso, evidencia-se que a classificação genérica de $A p h a$ nostoma orphinum ainda não pode ser considerada suficientemente assegurada.

\section{Genus : Convoluta Örsted (1843, p. 567)}

As 9 espécies nórdicas foram agrupadas na chave de Westblad (1946, p. 44) conforme a presença e ausência de olhos e de algas simbiônticas. O 
grupo sem olhos e sem algas, que abrange 7 destas espécies, foi dividido segundo a união ou separação dos poros genitais. C. divæx, sem olhos e sem algas e com um único poro genital tem, com isso, o seu lugar definido, no sistema de Convoluta.

Comparámos, naturalmente, também as espécies de Convoluta e de Monochoerus (sinônimo de Convoluta) não contidas na chave citada, mas não encontrámos espécies mais semelhantes à atual que as do sub-grupo mencionado.

Salientamos, nesta ocasião, a existência de uma espécie com olhos, sem algas, mas com pigmento, Convoluta lineata (Peebles 1915, p. 298). Nesta ocorre também o órgão glandular, segundo Westblad (1946, p. 21), de veneno, apôsto à vagina como em $C$. flavibacillum Jens. A autora não menciona o órgão na descrição de lineata, mas êste vê-se na figura 8 (na p. 300), onde se abre nitidamente na vagina ("genital duct").

\section{Convoluta divæ, spec. nov. (Figs. 6-7, 21-23)}

Os vermes têem forma de sola, sendo anteriormente arredondados, posteriormente truncados (Fig. 6). O comprimento é de $0,84 \mathrm{~mm}$., no estado vivente. $O$ endocício é verde-azul, mas os outros tecidos são incolores. Durante a natação enrolam os animais frequentemente as partes ântero-laterais para o lado ventral. Não pulam na água, mas aderem ao substrato, provavelmente por meio da secreção cianófila das glândulas caudais (Fig. 21, d).

O epicício (Fig. 23,h) é provido de núcleos intra-epiteliais e de rabditos (r) dispostos em séries (Fig. 7). A camada celular do ectocício (Fig. 23,j) é muito estreita e, nomeadamente na cabeça e na cauda, seguida por vacúolos, atravessados por pontes plasmáticas. Estes vacúolos circundam o endocício (i), por sua vez vacuolizado e nitidamente delimitado. Diatomáceas reconhecem-se como inclusões alimentares (Fig. 21). A bôca (b), na metade anterior do corpo, é marcada por glândulas bucais (k), cianófilas, e pela supressão dos vacúolos ectociciais. A supressão dêstes permite aproximar-se o endocício à superfície do ventre. Outras glândulas cianófilas são as glândulas (g) ao redor do gonóporo (z) e as do órgão frontal (f). As últimas são principalmente desenvolvidas ventralmente ao cérebro (c) e ao estatocisto (e), possivelmente em consequência do grande vacúolo ântero-dorsal do ectocício. Os dutos das glândulas frontais desembocam reunidos em uma reentrância do integumento da face anterior. Tanto a musculatura cutânea quanto a parenquimática são fracas.

Os testículos (t) são dorso-laterais (Fig. 6, 21). Os tratos dos espermatozóides dilatam-se ao nível do gonóporo (z), formando as chamadas vesículas seminais falsas (l). Os espermatozóides acumulam-se na cavidade interna da vesícula seminal (Fig. 23,s). Aí encontra-se ainda secreção granulosa (u), eritrófila, fornecida por células parietais (v) da vesícula. A parede da última possue fortes músculos longitudinais $(\mathrm{ms})$, cuja contração provocará a evaginação do penis (p). Aquela parte da vesícula seminal que abriga o penis chama Westblad de saco do penis ("Penissack"). O órgão copulador masculino é formado por músculos anelares (w) e epitélio (x). As células epiteliais mostram pelos núcleos lobulados o aspecto típico de células em atividade secretora. Produzem a secreção penial (y) eritrófila e semelhante 
à granulosa (u). A vesícula seminal (ou saco do penis) solda-se ao átrio (a). Este, assim como o gonóporo $(\mathbf{z})$ e a vagina (q), são ciliados. As glândulas (g) do gonóporo formam dois tufos que se estendem, principalmente, para trás, nos dois lados da vesícula seminal (Fig. 6). Provavelmente a secreção basófila destas glândulas cola os vermes durante a copulação (Westblad 1948, p 42). O gonóporo é provido de um esfíncter (sr).

Os ovários (o) são látero-ventrais. A curta vagina ciliada (q) que sáe do átrio (a) abre-se em uma bursa volumosa, esférica (m), nitidamente demarcada da vagina. A parede da bursa é sólida, evidentemente cuticularizada. A pequena palheta cuticular da bursa (Fig. 22) apresenta-se diversamente, nos vários vermes examinados, conforme a sua contração e dilatação. A palheta revela-se, com isso, muito elástica. Atraves da palheta passam os espermatozóides da bursa à vesícula parenquimática (Fig. 21, n), a "Spermienblase" (sb) das figuras de Westblad (1946, p. 53). Esta vesícula é encravada entre os ovócitos mais crescidos.

Ocorrência: Ilha de São Sebastião, na areia grossa, abaixo da linha da vasante regular; ca. de 20 exemplares, em novembro de 1949.

A espécie é dedicada à nossa estimada companheira de trabalho Dra. D. Diva Diniz Correa.

\section{Discussão de Convoluta divæ}

Dentro do sub-grupo mencionado, no comentário relativo ao gênero, duas espécies possuem órgão copulatório masculino volumoso : C. saliens Graff (nomenclatura antiga; veja Westblad 1948, p. 3) e C. norvegica Westbl. O penis de C. saliens é formado por alongamento da vesícula seminal que se torna tubulosa. A palheta da bursa de saliens é comprida. O órgão copulador de $C$. norvegica dirige-se para trás, é protráctil, mas não evaginável. A bursa de norvegica é indistintamente separada da vagina. C. flavibacillum Jens. possue o órgão masculino mais próximo do de divæ, mas tem vagina comprida, olhos e algas simbiônticas. C. lineata (Peebles) distingue-se de $C$. divæ pelos olhos, as células pigmentadas do parênquima, a vagina comprida e a ausência de glândulas frontais.

\section{Genus : Amphiscolops Graff (1905, p. 25)}

Amphiscolops sargassi Hym. (Figs. 24-32)

Amphiscolops sargassi Hyman 1939, p. 5 t. 2 f. 7.

Os vermes achatados atingem $3 \mathrm{~mm}$. de comprimento; os menores, numerosos no material presente, são todos imaturos. Dois lóbulos látero-caudais são constantemente desenvolvidos ; de resto, variam tanto a forma como a proporção entre comprimento e largura consideravelmente (Fig. 25). A côr acastanhada, "havana", é condicionada por algas geralmente chamadas de Zooxantelas, mas, segundo Buchner (1930, p. 134), não definidas sistematicamente. Em alguns vermes grandes, concrementos formam ainda faixas claras dorso-medianas, dorso-laterais e ao redor da extremidade anterior (Fig. 24). São de extensão variável, como em outras espécies de $A m$ phiscolops. 
Os simbiontes (Fig. 32) teem diâmetro de 0,012-0,028 mm., mais frequentemente, 0,014-0,018 mm. São esféricos e delimitados por contôrno nítido, talvez uma membrana plasmática (Buchner 1930, p. 129). O plasma tem côr de azeitona pálida, nos cortes corados com hematoxilina-eosina. Circunda um grande vacúolo, em cujo centro se situa um corpúsculo estrelar, provavelmente o pirenóide, nos cortes, vermelho. De resto, o vacúolo apresenta-se vazio. No plasma periférico encontra-se o núcleo. A grossura dêste torna muitas vezes excêntrica a posição do vacúolo. Ao lado do núcleo ocorrem os cromatóforos. A maioria dos simbiontes (z) ocupa o ectocício (parênquima externo) do dorso, situando-se entre os núcleos aprofundados da epiderme (c) e internamente a êstes. Menos numerosas são as algas no ectocício ventral (Fig. 29) ; algumas ocorrem ainda no endocício (parênquima interno). Em toda a parte são seguradas por células do Turbelário. Este alimenta-se dos simbiontes que se aproveitam dos produtos finais do metabolismo animal (Buchner 1930, p. 196-197) p. e., dos concrementos acima mencionados, nos cortes, dissolvidos.

Os cílios (Fig. 26) dispõem-se em séries longitudinais e são um pouco mais compridos (7 micra) que o diâmetro da camada cobertora (epicício) e da musculatura cutânea juntas (6 micra). Os núcleos (c) do epicício são aprofundados na maior parte do corpo, mas, em um ou outro verme ocorrem também núcleos intra-epiciciais (Fig. 29, c), p. e., ao redor da bôca e na extremidade caudal. Limites intercelulares não se vêem, nem mesmo em cortes tangenciais. Glândulas cianófilas (g) mucosas (Westblad 1948, p. 14) situam-se internamente aos núcleos aprofundados e à musculatura cutânea ; a secreção azul-negra amorfa sobrepõe-se aos cílios. Rabditos não existem. As glândulas frontais desembocam, por via de regra, separadamente no bordo anterior; excepcionalmente coalescem alguns dutos eferentes delas, simulando um órgão frontal. Fosseta frontal não ocorre. A musculatura anelar (a) é forte e compõe-se de fibras intervaladamente dispostas. As fibras longitudinais são mais raras e não formam músculo marginal especial.

O ectocício é denso, rico em células; o endocício (i), vacuolizado e frouxo. Apesar de músculos dorso-ventrais (m) traspassarem o parênquima digestivo, êste incorpora presas em grande quantidade (Fig. 28). De Copépodos e Turbelários (Enterostomula evelinæ e Cylindrostomum netsicum dos Holocoela) até 6 podem ser encontrados simultaneamente no endocício, apresentando várias fases de digestão. Um $A$. sargassi de comprimento de $0,8 \mathrm{~mm}$. e largura de $0,5 \mathrm{~mm}$. continha, além de 4 Copépodos, ainda um Amphípodo 0,4 mm., ao comprido, e de largura de $0,35 \mathrm{~mm}$. O endocício atinge a superfície no meio do ventre. Aí delimita-se a bôca (b) por interrupção do ectocício, mas não há faringe nem esfíncter bucal. O endocício alcança os lóbulos látero-caudais.

$\mathrm{O}$ cérebro (Fig. 27, e) situa-se no ectocício da região ântero-dorsal e compõe-se de dois gânglios largamente concrescidos. Dos três pares de nervos que saem do cérebro para trás, como na maioria dos Acoela (Westblad 1948, p. 23), os laterais (n) são os mais fortes. Internamente a êstes dispõem-se os nervos ventrais (f) e, menos distantes do plano mediano, os dorsais (d). Os nervos laterais são reunidos por comissura pré-cerebral (j) por sua vez ligada ao cérebro (e) por numerosos conectivos (h). Orgãos sensoriais de Luther ( $\mathrm{s}$ ) ocorrem nos bordos anterior e laterais, em comunicação com a comissura pré-cerebral (j) e os nervos laterais (n), respecti- 
vamente. Estatocisto não existe, como em A. evelinx. Dois olhos castanhos situam-se ao lado do cérebro (Fig. 28) no parênquima externo. São imperceptíveis nos cortes, como em Convoluta pelagica. Nesta espécie ocorrem ao nível do estatocisto, portanto também no ectocício. Assim sendo, revela-se inadequada a denominação "olhos epiteliais" (Löhner \& Micoletzky 1911a,p. 395). Esta parece aplicável em espécies como Otocelis rubropunctata (Brinkmann 1905, p. 41 : "öjnene ere diffuse indlejringer af pigment i epitheliet").

As gônadas e os órgãos copulatórios encontram-se na região ventral do endocício. Os vermes são proterândricos, pois testículos jovens ocorrem já em animais de $1 \mathrm{~mm}$., ao comprido. Os testículos (t) são laterais. O achatamento do corpo torna inconspícua a diferença entre "dorsal" e "ventral", mas os testículos são, em oposição à regra (Westblad 1948, p. 26), na sua maioria mais ventrais que dorsais. No material presente que abrange somente poucos exemplares aproximadamente maduros, os testículos compõem-se de pequenos grupos de poucas células volumosas que começam ao nível do cérebro (e). Os tratos de espermatozóides que representam os chamados "dutos eferentes" ainda não são desenvolvidos. Interna e caudalmente aos testículos ocorrem os ovários (o). Na região dos ovócitos em crescimento distinguem-se células germinativas e células (Fig. 29, r) que formam a parede e o estroma ováricos. Correspondem ao estroma descoberto por Westblad (1940, p. 19) na região ovárica do ovariotestis de Diopisthoporus longitubus Westbl. A parede de cada ovário prolonga-se para trás como cordão grosso (v), em que 2-3 palhetas bursais (q) penetram. Ligado na região mediana ao cordão do outro lado (Fig. 30), cada cordão concresce, além disso, com o integumento ventral, de cada lado da bursa. Nos pontos (w) em que os cordões se soldam com o epicício, apresenta-se êste interrompido. Possivelmente os ovos serão eliminados nestes pontos. Se fosse assim, os cordões (v) funcionariam como ovidutos; seriam os únicos representantes de vias eferentes femininas preformadas entre os Acoela.

No poro feminino (x) começa a vagina (l), um tubo grosso, de epitélio ciliado e núcleos aprofundados, dotado de musculatura anelar forte. A bursa (y) é atravessada pelo endocício e indistintamente delimitada dêste ; forma dois divertículos que divergem da vagina para os dois lados e se dirigem anterior e ventralmente. Cada divertículo contém 2-3 palhetas (q) que penetram no cordão ovárico (v) do lado correspondente. A palheta (Fig. 31) começa com base encurvada e larga, de cutícula anelada e termina com ponta reta, estreita, de cutícula lisa.

$\mathrm{O}$ órgão copulador masculino dista longamente do orifício $(\mathrm{x})$ da vagina. O compartimento interno (k) contém secreção granulosa. Se houvesse espérmios maduros no material disponível, tais alojar-se-iam, presumivelmente, também nesta vesícula. O trecho seguinte, ciliado, de núcleos aprofundados e de parede musculosa, é evaginável e representa o órgão copulatório (am) propriamente dito. Corresponde ao átrio evaginável de Haploposthia (Westblad 1945, p. 11, 22). A dobra póstero-caudal (u) consideramos homóloga ao guia espermático ("sperm guide" Hyman 1937, p. 323 f. 3, 7) de Amphiscolops langerhansi.

Ocorrência: Litoral superior da ilha de São Sebastião, entre algas (Sargassum stenophyllum) crescidas nas rochas. Os vermes ocorrem aí durante o ano inteiro, mas vermes aproximadamente maduros obtivemos, até agora, somente em meados de abril de 1949. 


\section{Discussão de Amphiscolops sargassi}

As Convolutidæ com palheta cuticularizada da bursa abrangem, segundo Westblad (1948, p. 57), três gêneros. Convoluta Örst. tem uma palheta; Amphiscolops Graff e Polychoerus Mark, duas ou mais palhetas. Os dois últimos gêneros distinguem-se pela presença (Polychoerus) e ausência ( $\mathrm{Am}$ phiscolops) de apêndices caudais, filiformes e contrácteis. São as seguintes as espécies válidas de Amphiscolops:

1) cinereus (Graff 1874, p. 151) ; 2) langerhansi (Graff 1882, p. 234); 3) australis (Haswell 1905, p. 426) ; 4) fuligineus Peebles (1915, p. 304); 5) bermudensis Hyman (1939, p. 3) ; 6) sargassi Hyman $(1939$, p. 5) ; 7) evelinæ Marcus (1947, p. 159). Estas espécies podem ser determinadas pela chave seguinte :

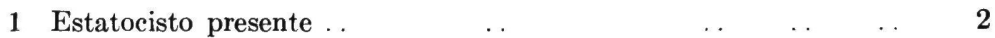

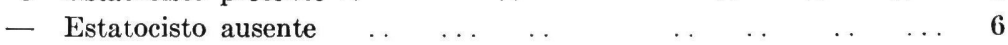

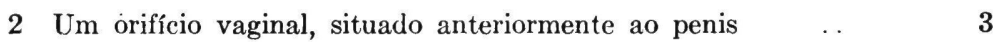

- Dois orifícios vaginais, situados nos dois lados do penis. .bermudensis

3 Dois lóbulos látero-caudais, projetados para trás $\quad \ldots \quad 4$

- Sem lóbulos látero-caudais proeminentes _. 5

4 Bursa esférica, central, com um grupo mediano de palhetas

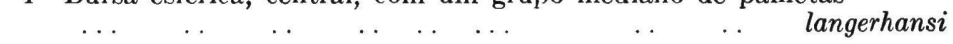

- Bursa bipartida com dois grupos de palhetas, largamente separados

5 Cinzento-azulado, esverdeado ou verde pálido ; ântero-lateralmente orelhado .. .. $\quad . . .4$. . cinereus

- Acastanhado, anteriormente branco e aí arredondado, sem orelhinhas ... $\quad . \quad$.. fu! igineus

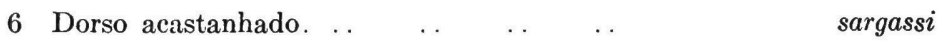

- Dorso lateralmente branco, no meio amarelo com escudo côr de anil

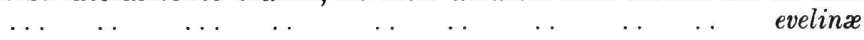

A. sargassi foi descrito sem órgãos reprodutivos. A falta do estatocisto, a côr, os lóbulos caudais, o tamanho e a forma do corpo tornam muito provável tratar-se, no material presente, da espécie descrita das ilhas Bermudas. Aí foi encontrada entre Sargassum flutuante, cuja origem pelágica ou nerítica não se conhecia.

\section{Ordo : Macrostomida Meixner $(1924$, p. $19 ; 1938$, p. 3)}

\section{Família : Microstomidx Vejdovsky (1882, p. 54; Luther 1907, p. 718) Genus : Microstomum O. Schmidt (1848, p. 56) Microstomum gabriellæ, spec. nov. (Figs. 33-38)}

Vermes viventes teem até $3 \mathrm{~mm}$., ao comprido; conservados, não mais que $1 \mathrm{~mm}$. e diâmetro de $0,12 \mathrm{~mm}$. Reconhecem-se até 7 zoóides nas cadeias vivas ; nas fixadas dá-se, em traços gerais, o mesmo, mas primórdios ulteriores ocorrem ainda. A côr é avermelhada; duas manchas oculares, granulosas, côr de tijolo, ressaltam-se na cabeça dos animais viventes (Fig. 33 , o), mas não se vêem mais nas preparações totais e nos cortes. A extremidade anterior termina com ponta obtusa. Na posterior, notam-se células adesivas (h) em grande número. Os dutos eferentes destas células glandu- 
lares saem fora da epiderme. A parte extra-epidérmica (Fig. 35,h) pode alcançar a altura dos cílios. Quanto a $M$. gabriellæ, não concordamos com Hofsten (1907, p. 465-466) que opinou a respeito das papilas adesivas de Microstomum baseado nos seus cortes de Dalyellia e Castrada. Confirmamos o achado de Wagner (1891) que foi repetido no "Bronn" (Graff 1904-08, p. 2023). Os dutos com a secreção ("Sekretpfröpfe") destacam-se entre os ć́lios. Somente o número das células adesivas da espécie atual é muito maior do que o da pesquisada por Wagner, $M$. lineare, em que há 10-30 caudais. Já em zoóides jovens de $M$. gabriellæ, há ca. de 60 papilas adesivas ; em zoóides mais desenvolvidos, ca. de 200, e na extremidade posterior do zoóide mais velho (Fig. 33), inúmeras. Espalhadas na superfície inteira observam-se, no verme total, ainda mais células adesivas e outras, com rabditos (Fig. 34,r). As fossetas ciliadas (Fig. 37,w), pequenas mas profundas, situam-se à altura do bordo posterior do cérebro. A bôca (b) é uma fenda longitudinal ; o intestino (i) termina pouco antes da extremidade posterior.

O comprimento dos cílios locomotores $(0,007 \mathrm{~mm}$.) ultrapassa a altura da epiderme $(0,005 \mathrm{~mm}$.). Os núcleos epidérmicos são, na sua maioria, intra-epiteliais (Fig. 34,x); nas fossetas ciliadas (Fig. 37,w) e em toda a região entre estas e a extremidade anterior, são aprofundados (v). Os limites entre as células da epiderme evidenciam-se em cortes tangenciais. As células epidérmicas rabditógenas ( $\mathrm{r}$ ) são duas vezes tão altas $(0,011 \mathrm{~mm}$.) quão as ciliadas ; salientam-se na superfície e deprimem, na base, as camadas subjacentes, i. é, a membrana basilar e a musculatura anelar (a). Os feixes de 10-20 rabditos perpendicularmente dispostos tingem-se pouco; são ligeiramente acidófilos. Estes rabditos dermáticos, escassos, mas distribuidos em todo o corpo, contrastam com as observações relativas a outras espécies do gênero (Graff 1904-08, p. 2034, nota ; Hofsten 1907, p. 396 ; Riedel 1932, p. 39 t. 1 f. 2). Nematocistos não ocorrem.

A membrana basilar, que é tênue, constitue o primeiro índice do desenvolvimento de uma zona de divisão, pois ela se dobra para dentro, formando assim o septo separador. Fases iniciais, em que os septos ainda não atingem o intestino, mostram esta origem dos mesmos ; não proveem da musculatura esplâncnica (Wagner 1890, p. 366). A disposição do tubo músculo-dermático não concorda com a de $M$. lineare (Hofsten 1907, p. 397), onde as fibras anelares e longitudinais são regularmente contíguas. Em $M$. gabriellæ intercalam-se entre os músculos anelares (Fig. 35,a) e longitudinais (d) várias glândulas. 1) Glândulas adesivas, eritrófilas (h), numerosíssimas na cauda, mas escassamente espalhadas nas outras partes. 2) Glândulas cianófilas pequenas (s), mais frequentes na região anterior que na posterior. 3) Grandes glândulas eosinófilas, de diâmetro de 0,015-0,03 mm., as mais das vezes vazias (l) nos cortes, frequentemente vistas com dutos intra-epidérmicos, e, em alguns casos, com conteúdo homogêneo (u). Estes vacúolos faltam nas zonas em que as constrições separadoras entre os zoóides se esboçam. Correspondem às glândulas mucosas de $M$ lineare (Graff 1904-08, t. 10 f. 3 , hd), mas são muito maiores. Até além da musculatura longitudinal aprofundam-se as glândulas cefálicas (k) que atingem o cérebro (c). Em parte são cianófilas, em parte eritrófilas. Os dois tipos desembocam na extremidade anterior. Aí os seus orifícios formam dois círculos concêntricos ; os basófilos, o externo, os acidófilos, o interno. O parênquima ocupa 
o espaço entre os músculos anelares e longitudinais, assim como a região internamente aos últimos. Fazem parte do parênquima as células formadoras (t) que são cianófilas e providas de núcleos volumosos. As fibras da musculatura cutânea longitudinal (d) são nítidas apenas nas regiões em que não confinam com a musculatura esplâncnica, p. e., nas partes em que há elementos do sistema nervoso interpostos, ou glândulas faríngeas, ou células formadoras das zonas de divisão, ou ainda glândulas adesivas caudais. Existem ca. de 12 destas fibras longitudinais que são fortes.

A bôca (b) situada ventral não anteriormente à faringe (f) constitue o orifício do saco faríngeo que é dobrado e muito dilatável. O epitélio da faringe é ciliado; os núcleos são, em parte, intra-epiteliais (z), em parte, aprofundados $(\mathrm{y})$. A certa distância da bôca, no limite entre o terço externo e o médio da faringe, desembocam glândulas eritrófilas (g). Na mesma região, mas também em outras partes da faringe, abrem-se glândulas cianófilas (j), de maneira que não há trechos extensos da faringe que estejam isentos de glândulas. A musculatura da faringe é fraca e de posição inversa à da cutânea (literatura: Marcus 1945, p. 30). A faringe é provida de um anel nervoso (p) completamente fechado. Este anel é ligado ao cérebro (c) por dois nervos curtos e tênues. A topografia corresponde aos achados de Wagner (1890, t. 24 f. 29, phr), completados por Luther (1904, p. 76, nota 1) e apresentados por Graff (1904-08, p. 2167 f. 36 no texto) e Hofsten (1907, p. 401-402). Kepner \& Taliaferro (1912, p. 43) não reconheceram a configuração anelar do suprimento nervoso da faringe e, por isso, falam só de uma comissura post-faríngea, entre os nervos "ventro-laterais" Estes nada mais são do que os dois finos nervos cérebro-faríngeos descobertos por Luther (= phn da figura citada do "Bronn").

$\mathrm{O}$ epitélio intestinal é finamente ciliado, notando-se, na base dêste, células substituidoras. A musculatura intestinal já foi mencionada. Algumas células claviformes de Minot ocorrem entre as células ciliadas, mas a maior parte das clavas acumula-se na bôca intestinal, situada dorso-caudalmente à bôca faríngea. As clavas podem projetar-se para fora, i. é, para dentro da cavidade faríngea, formando uma tampa, sem dúvida eficiente na lubrificação da presa. O mesmo "piston" foi visto por Kepner \& Helvestine (1920, p. 311) que o combinaram com o modo de alimentação de $M$. caudatum (Leidy). Esta espécie engole a presa por sucção. A julgar por alguns Copépodos esvasiados dos seus tecidos, que observámos no lume do intestino do nosso material, digere $M$. gabriellæ extra-celularmente, como Stenostomum, e é também engulidor ("Schlinger"). Sucção e macrofagia de presas volumosas ocorrem combinadas também em Stenostomum (Marcus 1945, p. 35). O intestino prolonga-se, para diante na forma de um ceco sólido, até além do cérebro (c). Não vimos órgãos excretores e reprodutivos.

Ocorrência: Entre algas, principalmente Sargassum stenophyllum, crescidas em pedras do litoral da ilha de São Sebastião, na zona da linha da vasante regulir. Ca. de 50 espécimes, todos em divisão, sem gônadas; abril, junho e novembro de 1949 .

A espécie foi denominada em homenagem à memória da nossa querida aluna, Dra. Gabriella P. Zuccari. 


\section{Discussão de Microstomum gabriellæ}

Do gênero Microstomum conhecem-se 14 espécies marinhas, encontradas na Arctis, no Atlântico septentrional (costas europeas e americanas), no mar do Norte e no Báltico, nos mares Mediterrâneo e Negro. A monografia de Graff (1913, p. 36-46) abrange as espécies seguintes:
1) davenporti Graff
2) groenlandicum (Lev.)
3) lineare (O. F. Müll.)
4) lucidum (Fuhrm.) 5) mundum Graff
7) ornatum Uljanin
8) rubromaculatum (Graff)
6) papillosum (Graff)
9) septentrionale (Sabuss.).

Destas espécies sómente 2) e 3) têem olhos. O olho de 2) é uma única mancha vermelha oval, transversalmente sobreposta ao cérebro ; o intestino de 2) é provido de divertículos laterais, por sua vez, secundariamente lobulados. Espécie 3) possue rabditos sómente na região anterior do corpo ; o ceco pré-oral não se estende além das fossetas ciliadas para diante.

Depois da publicação citada foram ainda descritas outras espécies marinhas, a saber :

10) dermophthalmum Riedel (1932,p.73)

12) melanophthalmum Steinböck (1933,p.9)

11) jenseni Riedel (1932,p.75)

14) tortipenis Steinböck $(1938, p .7)$.

13) mortenseni Riedel (1932,p.77)

Espécies com olhos são 10) e 12). Em 10) são covinhas epiteliais ; em 12), olhos pretos combinados com células refrativas (cristalinos). As células rabditógenas da espécie 10) restringem-se, principalmente, às extremidades anterior e posterior.

Stenostomum sieboldii Graff, que se aproxima ao gênero Microstomum (Meixner 1924, p. 19 ; Nuttycombe \& Waters 1938, p. 217), não tem olhos.

\section{Microstomum trichotum, spec. nov. (Figs. 39-41)}

Os vermes viventes (Fig. 39) lembram os do gênero Alaurina (Reisinger 1934, f. 2), mas a extremidade anterior é densamente ciliada (Fig. 40), não desenvolvida como proboscis provida de papilas e, por isso, trata-se, evidentemente, de uma espécie de Microstomum. O comprimento de uma cadeia vivente de 3 zoóides é de ca. de $0,5 \mathrm{~mm}$. ; a grossura, de ca. de 0,06 $\mathrm{mm}$. A côr é branca. Os feixes dos rabditos (r) adenais, até 28 micra, ao comprido, no verme virente, ressaltam-se na superfície de um modo muito característico. Olhos não ocorrem, pelo menos não se notam nos vermes viventes. A extremidade anterior é cônica; a posterior, arredondada ou truncada, e provida de ca. de 20 papilas adesivas (Fig. 41,k), de 5 micra de altura. As papilas diferem das da espécie precedente, pois são, como Hofsten (1907, p. 397) supôs, cêlulas epiteliais que se salientam. São alinguetadas ou fungiformes, sem cílios.

Nos cortes corados com hematoxilina-eosina, os rabditos (r) são de côr vermelha. Os feixes compõem-se de 6-8 rabditos e são, nos cortes, ca. de $0,022 \mathrm{~mm}$., ao comprido, cabendo $0,014 \mathrm{~mm}$. à parte sub-epidérmica ; 0,008 mm., à intra-epidérmica e à saliente para fora. O epitélio da epiderme mostra limites inter-celulares nítidos e núcleos em posição normal. A altura da epiderme é de 4-5 micra, na região anterior, e de 2-2,5 micra mais para trás. Também os cílios anteriores são bem maiores (ca. de 8 micra) que os do corpo restante (4-5 micra). Nematocistos não ocorrem. A membrana 
basilar é fina, mas nítida; a musculatura cutânea, pouco distinta. De glândulas cutâneas notam-se grandes, cefálicas (g), que desembocam isoladamente na região anterior. O parênquima (n) é rico em núcleos, acumulando-se as células formadoras ("neoblastos", "Stammzellen") nas zonas de divisão.

O cérebro (c) apresenta-se arredondado, nos cortes sagitais, e circundado por células ganglionares, numerosas na calota posterior. Os nervos principais, ventro-laterais, e a comissura caudal dêles foram reconhecidos. Além disso, notaram-se dois tratos anteriores de fibras nervosas revestidas por células ganglionares. Suprem dois botões (a) intra-epiteliais, situados entre os feixes de rabditos. A altura dos botões é de 9 micra; a largura, de 10 micra. São convexos e providos de curtos cílios, cujos grânulos basilares são distintos. Um núcleo e grânulos ligeiramente negrejantes pertencem a cada um dêstes botões, que se parecem, ainda que só remotamente, com os olhos epiteliais de Alaurina (Brinkmann 1905, t. 2 f. 10, 17), não com os de Microstomum dermophthalmum Riedel (1932, p. 54). As fossetas ciliadas são apenas ligeiras concavidades da epiderme.

O nível da bôca (b) corresponde, aproximadamente, ao do bordo posterior do cérebro (c) ; o tubo oral dilata-se, formando a faringe (f), caracterizada por epitélio de núcleos aprofundados e cílios compridos. Glândulas de secreção eritrófila (y) desembocam pouco entalmente à boca. A musculatura faríngea é tênue. Ao redor da entrada intestinal dispõem-se numerosas clavas de Minot (m). O intestino (i) estende-se com o seu ceco préoral até ao terço anterior do cérebro. As células intestinais, destituidas de cílios, incluem granulações de vários tipos ; o intestino contem Diatomáceas.

Os órgãos reprodutivos masculinos ocorrem no material aquí em mãos. $\mathrm{O}$ testículo (t) é impar, compacto e apõe-se à vesícula seminal (s), cujo estilete encurvado se projeta no pequeno átrio. Em uma das zonas de divisão existe o primórdio da gônada, provavelmente da masculina, composto por três grupos separados de células germinativas. As cadeias vistas por nós não contiveram mais que 3 zoóides.

Ocorrência: Ilha de São Sebastião, entre algas calcáreas (Corallinaceæ, Jania rubens L.), perto da linha da vasante ; 6 cadeias em junho de 1949.

\section{Discussão de Microstomum trichotum}

A proboscis táctil, destituida de cílios, das duas espécies planctônicas de Alaurina, A. composita e $A$. prolifera, a última ainda com cerdas simétricas, exclue estas, sem delongas, das proximidades de Microstomum trichotum. Alaurina alba, porém, possue tromba curta, cônica, ciliada, que passa sucessivamente, sem alargamento súbito, ao corpo restante. Brinkmann (1905, p. 57) considera-o concluidamente errado ("afgjort galt") chamar os órgãos adesivos da tromba de $A$. alba "papilas"; as figuras respectivas (l. c., t. 2 f. 4,5, x) sugerem tratar-se de botões de secreção fornecida por glândulas aprofundadas. Estas faltam na proboscis de Microstomum trichotum. Tão pouco existem, na espécie presente, os tratos de ramnitos de de $A$. alba. Os rabditos adenais desta não se salientam de tal modo na superfície como em .M. trichotum. 
O estado da literatura torna-o provável que apenas composita Metschn. e prolifera Busch pertencem a Alaurina. A independência de prolifera foi posta em dúvida (Brinkmann 1905, p. 66, nota 1), mas sendo prolifera o tipo do gênero, o nome de composita teria de desaparecer.

Outra espécie mal definida das Microstomidæ é Stenostomum sieboldii Graff (1878, p. 459, nota). Assemelha-se a Microstomum trichotum pelos pacotes piriformes de rabditos, mas distingue-se seguramente pela extremidade anterior largamente arredondada (Graff 1913, f. 38), as fossetas ciliadas profundas e as glândulas no bordo ental da faringe.

Restringe-se, destarte, a discussão de $M$. trichotum às outras espécies de Microstomum, cuja literatura já foi indicada na separação da espécie precedente. A chave de Graff (1913, p. 36-37) leva ao número 10. Aí encontramos $M$. davenporti, com tratos anteriores de rabditos; $M$. lucidum com rabditos não salientes e extremidade anterior arredondada; $M$. mundum com fossetas ciliadas profundas; $M$. ornatum anterior e posteriormente arredondado ; e $M$. punctatum, da água doce, com extremidade anterior cuneiforme e cauda cuspidata. Das espécies descritas posteriormente ao "Tierreich" comparamos apenas as sem olhos com a espécie presente, a saber, $M$. jenseni, com dois cecos intestinais posteriores e estilete comprido $(0,08 \mathrm{~mm}$.) ; $M$. mortenseni com fossetas ciliadas profundas (Riedel 1932, p. 55) ; e $M$. tortipenis, com estilete torcido e fossetas ciliadas distintas.

\section{Microstomum ulum, spec. nov. (Figs. 42-48)}

Os vermes, que formam cadeias de até 4 zoóides (Fig. 42), alcançam, no estado vivente, um pouco mais de um milímetro de comprimento e 0,12 $\mathrm{mm}$. de diâmetro. São incolores e destituidos de olhos. As fossetas ciliadas (w) são ovais transversais ; a bôca (b) apresenta-se como abertura circular. A extremidade anterior do verme vivente é bulbiforme, cuspidata e delimitada do corpo restante por uma constrição ao nível das fossetas ciliadas. Daí para trás, a largura continua uniforme até ao sulco separador da placa caudal, espatulada (Fig. 43) ou arredondada (Fig. 42). Glândulas grudadoras (k) guarnecem o bordo da placa. Os citosomas destas são aprofundados ; a secreção é eritrófila.

A altura da epiderme varia; no tronco, pode ser de 7 micra, inclusive os cílios ; na região cefálica, pode atingir 14 micra, cabendo 8 ao epitélio, 6 aos cílios. Os limites inter-celulares são distintos ; os núcleos, intra-epiteliais, também na ponta anterior. Em alguns exemplares, é verdade, faltam aí os núcleos ou tingem-se muito pouco, mas, ao que parece, são involuidos, não aprofundados.

Feixes de rabditos (r) são numerosos na região anterior, mas ocorrem também nas outras partes do corpo. As células rabditógenas aprofundam-se, devido ao seu grande tamanho (25 micra), e atingem a parede do intestino (i). Cortes tangenciais permitem avaliar em 50 o número de rabditos eritrófilos contidos em uma destas células. Lembram o aspecto dos rabditos de $M$. trichotum. Ainda ocorrem outras células (y), com secreção em forma de bastonetes grossos, espalhadas na parede do corpo. São fracamente tingíveis e, possivelmente, de secreção adesiva. Assemelham-se às células tidas por rabditógenas de $M$. gabriellæ, cujas células adesivas são diferentes. Em 
pequeno número, encontram-se nematocistos (Fig. 45, 48, s) em $M$. ulum. No integumento, associam-se sempre às células de bastonetes grossos (y). Nestas, um ou dois nematocistos ocorrem, com o polo da descarga para fora e o fio enrolado. Alguns nematocistos foram vistos no parênquima ; outros, com o fio desenroscado, grudados (u) entre os ćllios de uma preparação total (Fig. 45). Poderiam provir de hidrozoos tocados pelo turbelário ou do próprio Microstomum. No último caso, a descarga deveria ter sido condicionada químico-fisicamente, pela conservação com "Susa" quente, como parece ter acontecido no material de Riedel (1932, p. 50). Seja lembrado que os nematocistos de Microstomum, destituidos de cnidocílio, não explodem espontaneamente (Meixner 1923, p. 569). Glândulas cefálicas (h), de secreção basófila, desembocam avulsamente na extremidade anterior.

A membrana basilar é fina ; a musculatura cutânea, muito tênue. $O$ parênquima (o) é rico em células formativas (neoblastos), cujas acumulações com mitoses indicam os futuros planos de divisão $(x, z)$. O cérebro (c) ressalta-se, na preparação total (Fig. 45), pela cápsula nitidamente demarcada. Wagner $(1890$, p. 373) já relatou uma membrana ao redor do cérebro de $M$. lineare (Müll.). Os cortes mostram numerosas células ganglionares extracapsulares (Fig. 46, c) e algumas intra-capsulares, consistindo a massa intracapsular principalmente de neuropilema. Dos nervos posteriores (Fig. 45, n) há, pelo menos, dois pares, de cada lado. Como nas outras espécies do gênero, existe o anel nervoso faríngeo (Fig. 46, p). Ao nível do bordo posterior do cérebro situam-se as fossetas ciliadas (w), cuja entrada se estende, principalmente, em direção transversal. Os sacos profundos dêstes órgãos convergem atrás do cérebro. No bordo anterior das fossetas nota-se um tufo de cílios compridos que pertence a uma almofada de células (Fig. 47, t), com núcleos aprofundados, do tipo descoberto por Luther (1912, f. 10, c, d). Um dos nervos laterais (n) passa dorsalmente a esta almofada, muito perto dela.

A bôca (b) abre-se na faringe pequena (f) e pauci-glandular, revestida por cílios grossos e epitélio de núcleos normais. As glândulas faríngeas (g) são acidófilas. $\mathrm{Na}$ passagem da faringe ao intestino (i) ocorrem algumas células claviformes de Minot (m). O intestino pré-oral (q) é curto. As células intestinais podem apresentar-se individualizadas e agrupadas ao redor de um lume central ou coalescidas e formando uma massa cheia de grânulos. Hydrozoa e, uma vez (Fig. 44), o saco de ovos (e) de um Copépodo, foram encontrados no intestino. Gônadas não são desenvolvidas no material presente.

Ocorrência : Ilha de São Sebastião, na areia grossa com tufos de $\mathrm{Pa}$ dina, abaixo da linha da vasante regular. Na fauna acompanhadora destacam-se grandes Gyratrix hermaphroditus Ehrbg. e Dolichomacrostomum mortenseni (Fig. 49-52).

\section{Discussão de Microstomum ulum}

$M$. ulum precisa ser diferenciado das outras espécies marinhas do gênero que não possuem olhos. São estas, em ordem cronológica : ornatum: possue rabditos somente na região anterior do corpo. papillosum: o ceco pré-oral atinge quasi a extremidade anterior. lucidum: os rabditos não proeminam; as fossetas ciliadas são fracamente desenvolvidas. 
septentrionale: bôca uma fenda longitudinal ; glândulas cefálicas volumosas; terminação caudal sem papilas.

mundum : intestino com dilatações laterais, por sua vez, providas de lóbulos menores.

davenporti : com tratos de rabditos na extremidade anterior e fossetas ciliadas rasas.

jenseni: as fossetas ciliadas são minúsculas, reconhecíveis somente com aumento máximo: o intestino possue dois cecos látero-caudais.

mortenseni: de côr vermelha; o ceco pré-oral estende-se muito além do cérebro.

tortipenis: a extremidade anterior é cônica, sem constrição separadora do trecho seguinte do corpo.

trichotum : possue apenas 6-8 rabditos por célula rabditógena ; as fossetas ciliadas são ligeiras concavidades da epiderme.

Stenostomum sieboldii Graff (1878, p. 459, nota 1), de extremidade anterior arredondada, tem papilas em forma de acúleos moles, flexíveis, mas imóveis. Esta descrição parece excluir a possibilidade de se tratar de nematocistos explodidos. A expulsão do fio dos nematocistos, que se conhece como consequência da pressão nas preparações comprimidas, foi observada por Graff (l. c. ; 1904-08, p. 2042 ; 1913, p. 29). Isto torna mais improvável ainda que êle tenha confundido as papilas com fios de nematocistos.

Família : Macrostomida Van Beneden (1870, p. 129, 133)

\section{Genus : Macrostomum O. Schmidt (1848, p. 54 ; pro Macrostoma Örsted 1843)}

\section{Macrostomum evelinæ Marc.}

Macrostomum evelinx Miarcus 1946, p. 18 t. 3 f. 10-13.

Esta espécie até agora conhecida apenas da areia de uma localidade puramente marinha, que mesmo durante a vasante continua coberta pela água do mar aberto, obtivemos, em junho de 1949, na Ilha de S. Sebastião, na areia do bordo de um córrego de correnteza rápida que desemboca no mar. A água é doce durante as horas da vasante, mas a enchente penetra no córrego e a água torna-se salobra.

\section{Genus : Dolichomacrostomum Luther (1947, p. 29)}

\section{Dolichomacrostomum mortenseni, spec. nov. (Figs. 49-52)}

Os vermes adultos medem até 1,1-1,2 $\mathrm{mm}$. de comprimento e $0,2 \mathrm{~mm}$ de largura. A grossura (altura) não é ou quasi não é inferior à largura, mas os bordos laterais são um tanto acentuados, pois o corpo é aí ligeiramente achatado. Dá-se o mesmo com as extremidades anterior e posterior que são, além disso, cuspidatas. Da côr geral amarelada ressaltam-se os olhos pretos, juxtapostos. Anteriormente a êstes, um sulco circunda a ponta anterior; as células do sulco igualam às da epiderme restante. 
Os animais aderem ao substrato, por meio de células rabditígenas adenais (h), na cauda. Exemplares jovens nadam; adultos, não.

Os tecidos lembram os de $D$. lutheri Marcus (1948, p. 118) pela fraca tingibilidade dos núcleos, naquela espécie ainda mais pronunciada. A epiderme é lisa, não dobrada, como em D. uniporum Luther (1947, p. 30) e relativamente alta, acusando 6-14 micra, sem os cílios. Contém rabditos dermais (r) em grande número, ausentes em D. uniporum e D. lutheri. Ocorrem, além disso, rabditos adenais (h) tanto caudais, grudadores, quanto cefálicos. Os tratos dos últimos proveem de células situadas dorsalmente à faringe (f), ao nível da passagem desta ao intestino (i). Glândulas cefálicas, como existem em $D$. lutheri, são ausentes, faltando também cerdas tácteis. Os núcleos epidérmicos são intra-epiteliais. A camada das raizes dos cílios é alta e homogênea. A variação da altura da epiderme acima indicada deve-se mais à contração diversa dos músculos cutâneos que a diferenças na: várias regiões. A grossura dos músculos mencionados é de 3 micra.

O cérebro (c) sobrepõe-se à faringe e passa látero-caudalmente aos nervos longitudinais posteriores. Os olhos arredondados situam-se no bordo caudal do cérebro.

A bôca longitudinal (b) e a faringe (f) correspondem ao tipo conhecido de Macrostomum. Existem glândulas faríngeas eritrófilas, que são externas, e cianófilas, internas. A altura do epitélio ciliado que reveste a faringe é de 8 micra. Perto da passagem da faringe ao intestino ocorrem várias células claviformes de Minot, sendo estas raras nas partes posteriores do trato alimentar. O intestino é nitidamente delimitado contra o parênquima e provido de musculatura, reconhecível com imersão. Os contornos do intestino são lisos ; o epitélio é ciliado. Geralmente, ocorre um lume, em que notámos, principalmente, Diatomáceas, mas também Crustáceos e ovos. O intestino é comprido, pois atinge quasi o reservatório da secreção granulosa (w).

O volumoso testículo (t) é impar, como nas duas outras espécies do gênero, e, como nestas, situado no lado direito. O fino duto eferente (d) entra na vesícula seminal (v), seguida pelo reservatório da secreção granulosa (w). Tanto a vesícula quanto o reservatório são musculosos. A calota caudal do reservatório recebe a secreção das glândulas grânulo-secretoras, cujos citosomas (k) se dispõem dorso-lateralmente ao reservatório. Da calota rostral dêste sae o canal genital masculino (n) que continua ao redor do estilete ou tubo principal da terminologia de Luther $(1947$, p. 32). O órgão copulatório principal (p) corre no lado esquerdo, em direção ântero-ventral, como tubo cuticular, adelgaçado para fora. Termina em forma de gancho. A parede do canal masculino é tênue. $O$ gancho do estilete entra no átrio (Fig. 50, a) que é comprido, ciliado e dirigido para trás. Perto do gonóporo (g) que dista pouco da extremidade caudal do verme, encontram-se glândulas argamassadoras eritrófilas (j).

Dorsalmente ao início do tubo principal (p), sae o tubo secundário (q) do canal genital masculino (n). O percurso do tubo secundário é mais complicado que em $D$. uniporum ; em $D$. lutheri falta. Em $D$. mortenseni, êste tubo cuticular circunda, no seu início, o tubo principal no lado esquerdo, dirigindo-se, depois, dorsalmente. No trecho que sobe, é envolvido por musculatura (m) disposta em espiral. Ao atingir o seu ponto mais dorsal, o tubo apresenta uma espécie de articulação (Fig. 51), semelhante à descrita de 
D. uniporum Luther (1947, p. 33 f. 54) e comparável à do único tubo cuticular de Paramacrostomum tricladoides Riedel (1932, p. 66 f. 19 no texto da p. 65). Rostralmente à articulação (ou regulador do fluxo dos espermatozóides), o tubo secundário, agora mais largo, desce e entra em um órgão saculiforme (l). Este é internamente dobrado e membranoso, externamente glandular (Fig. 52). No lume do órgão glandular sobe o tubo secundário novamente, mas, aí, sem cúticula. Ao sair do saco, o tubo apresenta-se fortemente cuticularizado. Em forma de meia lua encurva-se esta parte (Fig. 50 , e) para o lado direito e para o ventre. Segue na extremidade ânteroventral da meia lua, uma dilatação (s), que desemboca no átrio por meio de um tubinho reto, anulado $(\mathrm{u})$. A parte dilatada e a reta, anulada, lembram respectivamente a ampola e a palheta de uma bursa. Também o ponto em que o tubo secundário termina, perto do ovócito mais crescido, no orifício interno do átrio, sugere a comparação com bursa e duto espermático. A única função imaginável do tubo secundário já foi, com toda reserva, suposta por Luther (1947, p. 34) : Seria um aparêlho que asseguraria autofecundação, se não houvesse fecundação por outro indivíduo. Infelizmente, tingem-se os espermatozóides, já na vesícula seminal, tão pouco, que não é possivel definir o conteudo da dilatação terminal do duto.

Os ovários (o) são pares, em oposição a $D$. uniporum e $D$. lutheri, e situam-se nos dois lados do intestino (i). Apõem-se intimamente a êste, como em Myozona evelinæ Marcus (1949, p. 21) e recebem, destarte, as substâncias alimentícias, diretamente. Anteriormente ao orifício interno do átrio, existe um único ovócito crescido de cada vez. Reencontram-se, em D. mortenseni, os órgãos auxiliares femininos de $D$. uniporum ou sejam, as glândulas produtoras da massa de secreção que contém peças cuticulares. As glândulas (y) situam-se rostralmente às grânulo-secretoras (k). São massiças, sem o lume canalicular revestido por epitélio ciliado, presente em $D$. uniporum. A disposição da massa de secreção (z) é a mesma como em uniporum, i. é, dorsal em relação ao canal genital masculino e ao tubo principal (p), caudal aos ovários (o). As peças cuticulares (x) das duas espécies são diferentes. As de uniporum são retas e dilatadas nas duas extremidades (Luther 1947, p. 35). As de mortenseni são enroscadas em uma das extremidades, de onde se estende um tubo reto ou quasi reto. Mesmo com esta forma singular poderiam ser envólucros de espermatóforos, mas, como o eventual conteudo delas não se tinge, nos cortes, ignora-se a função das peças cuticulares.

Ocorrência : Ilha de São Sebastião, na areia grossa com tufos de $\mathrm{Pa}$ dina e outras algas, abaixo da linha da vasante regular. Juntamente com Microstomum ulum (Fig. 42-48) e Gyratrix hermaphroditus Ehrbg. colhemos ca. de 40 exemplares da nova espécie, em vários estádios de idade.

Sendo esta a primeira espécie que obtivemos com a draga-trenó de Mortensen (1925), dedicámo-la gratamente ao nosso Mestre e velho Amigo, Dr. Th. Mortensen de Köbenhavn.

\section{Discussão de Dolichomacrostomum mortenseni}

A espécie difere de uniporum pelos ovários pares, pelo duto masculino secundário mais complicado e pelas glândulas do aparêlho feminino massiças, não epiteliais. Diferem, além disso, as peças cuticulares contidas na secreção feminina, o átrio comprido e largamente aberto e os rabditos dermais. 
D. lutheri é mais distante de mortenseni que uniporum, pois lutheri não tem tubo secundário e possue dois órgãos femininos, o ovóide ligado ao glandular e êste em comunicação com o átrio. O ovário de lutheri é impar. Além disso, existem glândulas cefálicas em lutheri e rabditos faltam completamente.

\section{Ordo : Rhabdocoela Graff (1882 ; Neorhabdocoela Meixner 1938 ;. Karling 1940)}

\section{Subordo : Dalyellioida Bresslau (1933, p. 261, 265; Dalyelliida Meixner 1924, p. 18)}

\section{Familia : Provorticidae Beklemischev (1927, p. 130)}

Adotando o âmbito da família, como foi definido por Karling (1940, p. 233-234), com excepção de Prorhynchopsis Beauchamp (1913, p. 299), apresentamos a chave seguinte dos gêneros das Provorticidæ:

1 Gônada feminina impar ou com vitelário impar $\quad \ldots \quad \ldots 2$

- Vitelários e ovários ou germovitelários pares $\quad . \quad 4 \quad \ldots .44$

2 Vitelário impar ; ovários pares. ... . . Pilgramilla Sekera (1911, p. 12 ; gênero incerto)

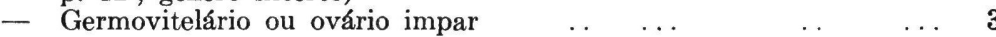

3 Germovitelário saculiforme ; duto ejaculatório fracamente cuticularizado. .. . . . . Archivortex Reisinger (1924a, p. 3)

- Ovário ramificado, quando adulto; vitelário reticulado; estilete penial flanqueado por dois acúleos curvos. .. Kirgisella Beklemischev (1922, p. 277 ; 1927, p. 113)

4 Testículos saculiformes, impares ou pares $\ldots \begin{array}{lllll} & \ldots & \ldots & \ldots & 5\end{array}$

- Testículos concrescidos, formando uma ferradura. . . $\quad \ldots$. Baicalellia Nassonov (1930, p. 727)

5 Orgão copulador masculino com um único bulbo $\ldots \begin{array}{llll}\ldots & \ldots & 6\end{array}$

- Orgão copulador masculino com vesícula seminal seguida por vesícula granulorum

6 Germovitelários cujas zonas germígenas passam às vitelógenas ; órgão masculino sem cuticularização. ... ... Haplovortex Reisinger (1924b, p. 232, 290)

- Ovários e vitelários separados, às vêzes contíguos ; penis circundado por tubo cuticular

7 Com útero, bursa e duto espermático; sem receptáculo seminal Provortex Graff (1882 ; Karling 1940, p. 233)

- Sem útero, bursa e duto espermático; com receptáculo seminal .. $\quad \ldots \quad$ Provortex virginiensis Ruebush \& Hayes $(1939$, p. 136)

8 Sem estilete Oekiocolax Reisinger (1929, p. 64)

- Com estilete ... ... ... . . .

9 Sem estatocisto $\begin{array}{lll}\cdots & \ldots & \\ . & \ldots & \text { Lurus, gen. nov. }\end{array}$

- Com estatocisto Hange-

10 Faringe com dutos glandulares intra-faríngeos. thellia Karling $(1940$, p. 14, 98, 233)

Faringe sem dutos glandulares internos
Graff (1905a, p. 73, 103; Luther 1948, p. 4) ${ }^{\text {- }} \quad$ Vejdovskya

Prorhynchopsis minuta, com germovitelários (Beauchamp 1913, p. 300), foi incluida nas Hypoblepharinidæ Böhmig (1914, p. 3) por Meixner (Stummer-Traunfels \& Meixner 1930, p. 3483). Também Hypoblepharina possue 
germo-vitelários (Meixner 1926, p. 596, nota 2 da p. 595). Karling (1940, p. 219, 234) coloca Prorhynchopsis nas Provorticidæ. O aspecto geral favorece isto, mas o material conservado, o único que se conhece das Hypoblepharinidæ, não proporciona uma idéia suficiente do hábito dêstes vermes, em estado vivente. A restrição dos cílios locomotores de Prorhynchopsis a uma faixa ventro-mediana e à região circum-oral ocorre também nas Hypoblepharinidæ. Parece-me que êste caracter excepcional pesa mais que a semelhança geral. A desembocadura do duto comum no átrio, ventralmente (rostralmente) ao duto ejaculatório, outro sinal importante das Hypoblepharinidæ, ainda não foi verificado em Prorhynchopsis, conhecida apenas de preparações totais. A bursa existe em Prorhynchopsis e nas Hypoblepharinidæ; o receptáculo seminal da primeira pode ser reconhecido na figure de Beauchamp. Com isso, prefiro, por emquanto, a sistematização da Meixner.

Pilgramilla Sekera é incerta. A diagnose não informa a respeito do órgão copulador masculino, afirma a existência de um vitelário indiviso e não define, univocamente, a gônada feminina como formada por dois ovários e um vitelário ou por germovitelários ("als ob sie ein einheitliches Organ bildeten" Sekera 1911, p. 11). Nestas circunstâncias, discordamos de Graff (1913, p. 78) e Ruebush \& Hayes (1939, p. 136) que incluiram Pilgramilla sphagnorum, sem delongas, no gênero Provortex.

O "Provortex affinis (Jensen 1878, p. 43)" descrito por Ruebush (1935, p. 305) não é esta espécie (Karling 1940, p. 113). O nome foi modificado em Provortex virginiensis Ruebush \& Hayes (1939, p. 136). O órgão definido como receptáculo, na diagnose original (1935), foi chamado "bursa seminalis", em 1939, mas não descrito novamente. A presença ou ausência "according the condition of the animal" (Ruebush 1935, p. 306) é invulgar para a bursa musculosa dos Dalyellioida. Por isso, mantivemos, na chave precedente, a terminologia original da organização de $P$ virginiensis, apontando, destarte, a posição sistemática ainda não completamente esclarecida dêste primeiro representante puramente límnico do gênero Provortex.

As Mesovorticidæ foram introduzidas sem quaisquer cortes (An der Lan 1939, p. 208) e são, por isso, mal conhecidas (Karling 1943, p. 18). A questão "germovitelário ou ovário e vitelário" necessita, na maioria dos casos, de cortes. Vê-se isto pela descrição da gônada feminina de Provortex pallidus Luther (1948, p. 17). No estado atual, existe ainda a possibilidade de se tratar, em Mesovortex stancovici, apenas de uma Dalyellia.

\section{Genus : Lurus, gen. nov.}

Provorticidæ com estatocisto, separação das vesículas seminal e granulorum e grande parte do comprido duto ejaculatório cuticularizada ; ovários e vitelários separados; bursa e duto espermático presentes.

Tipo do gênero: Lurus evelinæ, spec. nov.

Como único gênero dos Rhabdocœla com estatocisto, Lurus distingue-se suficientemente das Provorticidæ restantes. Os órgãos reprodutivos combinam caracteres desta família. Dentro das Provorticidæ, Lurus pertence ao grupo com separação da vesícula seminal e da vesícula granulorum, mas não se aproxima especialmente a um dos três outros gêneros, Vejdovskya, Oekiocolax e Hangethellia, dêste grupo. 


\section{Lurus evelinæ, spec. nov. (Figs. 53-57)}

Os vermes são incolores, alongados e esbeltos; no estado vivente (Fig. 53) teem $0,4 \mathrm{~mm}$., ao comprido e $0,04 \mathrm{~mm}$. de diâmetro. Anteriormente são cônicos; posteriormente arredondados, sem atenuação da largura. A transparência do corpo permite reconhecer, nos exemplares viventes um pouco comprimidos entre lâmina e lamínula, a topografia geral dos órgãos principais. Estereocílios sensoriais observam-se ao redor das extremidades anterior e posterior, havendo ainda alguns no corpo restante. A bôca (b) é terminal ; o gonóporo $(\mathrm{g})$, ventral, sub-terminal.

Nos cortes, reconhecem-se os limites das células epidérmicas, cujos núcleos alongados e muitas vezes horizontalmente dispostos são intra-epiteliais. Inclusões não se notam na epiderme. As únicas glândulas cutâneas são as caudais (Fig. 56, m), de secreção eritrófila, grudadora. A membrana basilar e o tubo músculo-dermático são finos. O cérebro (c) é de volume regular. Entre os lóbulos cerebrais posteriores situa-se o estatocisto (e) com dois estatolitos internos e 1-2 pequenos concrementos cristalóides, extracapsulares (Fig. 55), dissolvidos nos cortes. Aos poucos Turbelários com dois estatolitos (Westblad 1937, p. 86) junta-se ainda Rhynchoscolex evelinæ Marcus (1945a, p. 66). Olhos faltam na espécie presente.

Da bôca (b) sáe o tubo bucal (ir), comprido e fino, que se dilata, formando a bolsa faríngea, que é caudal ao estatocisto. A faringe (f), em forma de tonel (pharynx doliiformis), tem orla lisa (Fig. 54) e lume triangular. Tanto o epitélio interno quanto a musculatura da faringe são nucleados ; a musculatura radial é especialmente forte. A secreção das glândulas (h) na passagem da faringe ao intestino é cianófila ; não são clavas de Minot. Estas não se reconhecem nem no próprio intestino (i) que é curto, não se estendendo além dos ovários (o) para trás. O intestino é sincicial, sem lume e sem limites celulares distintos. Ocasionalmente foram encontradas Diatomáceas na massa intestinal.

Os dois compactos testículos (t) situam-se ventralmente à faringe. As vezes, são bem separados, outras vezes, aproximam-se um do outro e podem até coalescer. Sempre, porém, ocorrem dois dutos eferentes (Fig. 57, d) que se reunem na vesícula seminal (s), de parede tênue. Da vesícula sáe o duto ejaculatório $(\mathrm{u})$ e atravessa o reservatório $(\mathrm{k})$ da secreção granulosa. Aí os grânulos dispõem-se em pilhas. As numerosas glândulas grânulo-secretoras (j) são volumosas e preenchem grande parte da região póstero-ventral do corpo. Caudalmente ao reservatório continua o duto masculino (u), entalmente como canal de parede membranosa, ectalmente com cuticularização forte. Enrosca-se e forma uma espiral com duas circumvoluções. O calibre do duto continua o mesmo também no último trecho que é retamente dirigido para trás, onde entra, com dobras, na calota dorsal do átrio comum. Uma grande célula (z), formadora da cutícula, apõe-se à parte cuticularizada do duto ejaculatório. Lembra a célula que produz o estilete de Proschizorhynchus oculatus Meixner (1928, f. 8, bk) e a mesma de Togarma evelinæ Marcus (1949, f. 58, eu).

Os vitelários (Fig. 53, v) são caudais e látero-dorsais aos testículos (t). Compõem-se de 6-12 células enfileiradas, de cada lado. Desembocam na dilatação interna (ental) do canal genital feminino, o oótipo (Fig. 56, y) da terminologia de Luther (1948, p. 11). Nesta dilatação abrem-se também os 
ovários (o); as zonas germinativas dêstes dirigem-se dorso-caudalmente. As glândulas da casca (r), cuja secreção é derramada na mesma dilatação, salientam-se mais nos vermes viventes que nos cortes, sendo nêstes inconspícuas. O canal genital feminino (w) é frouxo. Desemboca no átrio (a), ventralmente ao duto ejaculatório $(\mathrm{u})$. O gonóporo $(\mathrm{g})$ é circundado por glândulas argamassadoras eritrófilas $(\mathrm{x})$. Ao lado da entrada do duto ejaculatório, sáe a bursa tubulosa (p) do átrio. A parte ental desta é ligeiramente dilatada e revestida por cutícula distinta. Possue dois orifícios, um lateral (q) e outro, sub-terminal, interno (n). A abertura lateral dirige-se para o parênquima. Talvez permita a saida de um eventual excesso de espermatozóides, que possivelmente passariam ao intestino. Mas, além da existência do orifício, não dispomos de observações. A abertura sub-terminal apresenta a palheta (n) fortemente cuticularizada do duto espermático (ds), que estabelece a comunicação da bursa com o chamado oótipo (y).

Ocorrência : Baía de Santos, práia José Menino, na areia fina, de côr cinzenta, entre as linhas das marés; ca. de 30 exemplares, em dezembro de 1949.

Subordo : Kalyptorhynchia Graff (1905a, p. 70)

Sectio : Schizorhynchia Meixner (1928, p. 230)

Família : Schizorhynchidæ Graff (1905a, p. 73)

Genus : Proschizorhynchus Meixner (1928, p. 237)

Proschizorhynchus atopus, spec. nov. (Figs. 58-60)

$\mathrm{O}$ verme maduro tinha, no estado conservado, 1,4 mm., ao comprido, e largura de aproximadamente $0,14 \mathrm{~mm}$. $O$ animal vivente não se diferenciou dos Seriata, juntamente com os quais foi capturado. O corpo é anteriormente mais esbelto que posteriormente. As pontas dorsal e ventral da proboscis (l) proeminam da bainha da tromba à maneira de hastes de uma tenaz (Fig. 58). Os olhos (a) são pequenos; pertencem ao tipo duplo, comum nos Kalyptorhynchia (Meixner 1925, p. 287-288), e são providos de células visuais, globosas e altamente refrativas, frequentemente descritas como "cristalinos" Pela sua coloração azul nos cortes tingidos com hematoxilina-eosina ressaltam-se duas cinturas de células adesivas (j) situadas na parte posterior do corpo.

A epiderme tem cílios curtos, núcleos lobulados e muitos vacúolos intercelulares, hialinos ("wasserklare Räume"). A membrana basilar é grossa ; as camadas anelar e longitudinal da musculatura cutânea são fortes. As glândulas adesivas emitem a sua secreção cianófila e bacilar através da epiderme, crivando-a em larga extensão. $O$ comprimento da tromba, que não tem núcleos, é de $0,17 \mathrm{~mm}$., nos cortes. Entre o grupo de retratores proboscidiais situa-se um tufo de glândulas da tromba (m) que quasi atinge o cérebro (c).

A faringe (f) é volumosa e de lume triangular. Encontra-se um pouco anteriormente ao meio do corpo e inclina-se nitidamente para diante. Da musculatura faríngea são especialmente fortes as fibras transversais e as anelares internas, menos as longitudinais externas. Músculos locomotores 
faríngeos ocorrem. O epitélio viloso do tubo oral passa ao ectalmente ciliado da faringe. No último faltam núcleos. As glândulas faríngeas eritrófilas circundam a bôca faríngea e a entrada do intestino, respectivamente. Alguns núcleos podem ser atribuidos ao trecho esofágico, caracterizado pela nítida membrana basilar acastanhada. O início do intestino é marcado por um anel de células claviformes de Minot. O lume do intestino (i) é obliterado e contém cerdas de Enchytræidæ, comuns na região da linha da enchente regular, em que o Schizorhynchio foi capturado.

Entre o cérebro (c) e a faringe (f) encontram-se os quatro testículos (t) ; os dois direitos são um pouco mais anteriores ; os esquerdos, algo mais posteriores. Os dutos eferentes alargam-se caudalmente à faringe, formando duas vesículas seminais (s), de paredes tênues. As vesículas emitem dutos que se reunem ventral e um pouco caudalmente à vesícula granulorum (k). O duto ejaculatório entra nesta vesícula que se dispõe perpendicularmente, em direção ventro-dorsal. Na vesícula da secreção granulosa ocorrem quatro núcleos internos, como foram desenhados de Schizorhynchoides diplorchis Meixner (1928, f. 9). A vesícula estreita-se e encurva-se para trás, formando uma papila penial. A bainha do penis (Fig. 59, q) e o estilete cuticular (ca. de $0,028 \mathrm{~mm}$., ao comprido) proeminam para dentro do átrio. $\mathrm{O}$ epitélio dêste é anfractuoso (y). Dois pequenos pacotes de glândulas eritrófilas desembocam na parede anterior do átrio.

O ovário (o) impar situa-se no lado esquerdo, caudalmente ao gonóporo (u). No lado direito forma o átrio uma bolsa dobrada caudal que não foi desenhada nas nossas figuras. Os vitelários (v) ocupam os dois lados da região entre a faringe (f) e a cintura posterior das glândulas adesivas (j) Dos vitelodutos vimos somente o esquerdo (w) que se reune com o curto oviduto. O duto feminino comum (d) apresenta-se como pequena dilatação tubulosa do átrio. No ponto da reunião do oviduto com os vitelodutos abre-se ainda o receptáculo seminal (r), órgão volumoso, aproximadamente globoso. A parede do receptáculo é formada por músculos grossos. Perto do receptáculo, encontra-se o orifício interno da vagina (x), igualmente musculosa. A desembocadura externa, atrial, da vagina é circundada por uma roseta de glândulas eritrófilas, talvez argamassadoras.

Como se vê pelo corte horizontal (Fig. 60), reunem-se os vários órgãos femininos um pouco à esquerda do plano mediano. Do ponto de encontro para trás sae mais um canal (e), cujo percurso encurvado acompanha a parede posterior do receptáculo seminal (r). E o canal da bursa. Como bursa consideramos o tufo de células cianófilas (b), presas à parede caudal do canal. Este é circundado por anel cuticular (n). Cuticularização do canal da bursa ou da entrada dela (palheta ; duto espermático) ocorre em muitos Kalyptorhynchia. Como exemplos dos Eukalyptorhynchia menc onamos somente duas espécies de Cicerina (Meixner 1928, p. 235, 236), Paulodora matarazzoi (Marcus 1948, p. 134-135) e Alcha evelinæ (id. 1949, p. 32) ; dos Schizorhynchia, em que dutos espermáticos cuticulares são a regra (Meixner 1928, p. 237), Paraschizorhynchus arenarius (Beauchamp 1927, p. 5) e Diascorhynchus borealis (Meixner 1928, p. 250). No caso presente, não é possivel estabelecer a analogia entre a palheta da bursa dos Acœla (Meixner 1938, p. 62) e o anel cuticular do canal da bursa, nem chamar êste canal de "duto espermático" A bursa de Proschizorhynchus atopus só pode ter função de "bursa resorbiens", não a de "bursa copulatrix" O canal continua além 
da inserção das células bursais ainda em direção dorsal. Este trecho (z) mede $0,02 \mathrm{~mm}$., ao comprido. Deve ser chamado canal bursa-intestinal, pois abre-se no tecido intestinal (i). Espermatozóides passam do canal ao intestino (Fig. 59). O gonóporo (u) é provido de dois esfíncteres.

Ocorrência : Ilha de São Sebastião, na areia fina, pouco abaixo da linha da enchente regular. Um exemplar iscado com peixe em abril de 1949.

\section{Discussão de Proschizorhynchus atopus}

As duas espécies certas que se conhecem, até agora, de Proschizorhynchus são $P$. oculatus Meixner (1928, p. 237, 239) e $P$ færoensis Meixner (1929, p. 766 ; 1938, f. 67). A primeira descrição ilustrada de $P$. færoensis, a de Steinböck (1931, p. 13), não concorda com a de Meixner (1929, p. 767) : "a vagina vinda de trás abre-se no átrio comum" Estas palavras caracterizam færæeensis suficientemente. Não está certo que Steinböck a chame de "nomen nudum" de Meixner e a descreva como "nov. spec." O nome deve ser færoensis Meixner.

A vagina de $P$ oculatus desemboca independentemente do átrio comum, atrás dêste ; em færæeensis, no átrio, segundo Meixner. O último tipo repete-se na espécie presente. Ambas as espécies anteriormente descritas teem testículos indivisos e são desprovidas de receptáculo seminal.

Em 1928, Meixner separou (p. 237) dois grupos das Schizorhynchidæ, cada um definido por vários caracteres. Dêstes, porém, somente a posição anterior ou posterior da faringe parece taxonomicamente aplicável, pois testículos indivisos ocorrem combinados com faringe anterior e posterior (Marcus 1949, p. 33-34). Testículos bipartidos, até agora só conhecidos do grupo com faringe posterior, ocorrem na espécie aquí em mãos que tem faringe anterior.

Com a reserva necessária em uma família ainda pouco conhecida definimos o $1 .^{\circ}$ grupo pela faringe anterior e, por isso, colocamos a nova espécie neste. Carcharodorhynchus Meixner (1938, p. 137) possue tromba com dentes cuticulares ; a posição da faringe e os testículos não foram descritos. Três gêneros perfazem o $1 .^{\circ}$ grupo, Proschizorhynchus Meixner, Paraschizorhynchus Meixner e Trapichorhynchus Marcus. $\mathrm{O}$ último gênero com aparêlho masculino muito singular não precisamos discutir. Dos dois outros, ambos com testículos indivisos, Paraschizorhynchus possue receptáculo seminal (Beauchamp 1927, p. 5 ; Marcus, l. c.) ; Proschizorhynchus, não. Apesar disso, não incorporamos o novo material em Paraschizorhynchus, pois, a peça cuticular masculina de $P$ arenarius (Beauch.) é complicada, não um estilete infundibuliforme simples; a vesícula seminal é impar, e a bursa compõe-se de duas partes: uma bolsa sincicial, bilobada, e uma vesícula.

A combinação de faringe anterior, testículos bipartidos e presença de receptáculo e bursa teriam, talvez, recomendado introduzir um novo gênero. Hesitamos em proceder assim, porque as espécies da Seç̧ão Schizorhynchia são poucas e heterogêneas. Ainda não se evidenciam nelas critérios sistematicamente aproveitáveis em número suficiente. 


\section{Genus : Schizorhynchoides Meixner (1928, p. 237) \\ Schizorhynchoides martæ, spec. nov. (Figs. 61-65)}

Os vermes filiformes, brancos e destituidos de olhos, lembram, pelo hábito geral e mesmo pelos movimentos, de certo modo, Nematodes. Frequentemente aderem com a extremidade posterior ao substrato, farejando com a anterior (Fig. 63), como foi desenhado por Meixner (1938, p. 12 f. 11 C. 1 , D. 1, D 2, F). O comprimento máximo de vermes viventes é de $1 \mathrm{~mm}$. (Fig. 62). Animais conservados atingem ca. de $0,55 \mathrm{~mm}$., ao comprido. A forma do corpo é grandemente variável : um exemplar, de comprimento de $0,8 \mathrm{~mm}$. e diâmetro de $0,04 \mathrm{~mm}$., acusou, quando contraido, $0,3 \mathrm{~mm}$., ao comprido, e diâmetro de $0,1 \mathrm{~mm}$. (Fig. 63). A faringe (Fig. 65, f) encontrase na metade posterior do corpo ; o gonóporo (g), anteriormente ao anel adesivo (k). Este é formado por uma série de células, que são crivadas pelos dutos de glândulas cutâneas aprofundadas.

A epiderme apresenta-se, mesmo em vermes fixados em estado estendido, transversalmente anelada, nas preparações totais e nos cortes. Os aneis são tão estreitos, que se vêem até em cortes transversais um pouco oblíquos (Fig. 61). De cortes tangenciais depreende-se que cada anel corresponde a ca. de 4 fibras anelares da musculatura cutânea; cada sulco epidérmico inter-anelar, a duas. Vermes estendidos teem aneis de ca. de 6 micra de largura (distância entre dois sulcos sucessivos) ; animais contraidos, muito mais estreitos (2,5 micra). Os núcleos epidérmicos, que são muito escassos, situam-se normal, i. é, intra-epitelialmente. Os cílios são uniformes, de ca. de 3 micra, ao comprido, com excepção de uma corôa de cílios maiores (ca. de 10 micra), ao redor do orifício da tromba. A membrana basilar é fina, mas ressalta-se pela côr acastanhada-preta, nos cortes corados com hematoxilina-eosina. Os músculos anelares são muito finos, mas cerradamente dispostos. Os músculos longitudinais são largos, correspondendo ca. de 3 fibras dêles ao espaço ocupado por 4 anelares, no verme estendido. Fibras diagonais não existem. A secreção pegajosa das glândulas adesivas, eliminada através das células (k) do anel pré-caudal, é cianófila. A própria cauda contém uma almofada de altas células (h), evidentemente de função mecânica, que são ligeiramente eritrófilas.

A bainha (Fig. 65, d) da tromba abre-se terminalmente, na ponta de um botão cônico, as mais das vezes separado da região seguinte por uma constrição. A bainha possue somente 2 núcleos, como em Sch. diplorchis Meixner (1928, p. 241). As duas metades da tromba (e) são cilíndricas, sendo cada uma circundada por membrana cuticularizada, como em Trapichorhynchus tapes Marcus (1949, p. 35). O comprimento da tromba é de ca. de $0,06 \mathrm{~mm}$., em um verme conservado de $0,56 \mathrm{~mm}$., de comprimento total. As glândulas proboscidiais (q) são da mesma longura como a tromba. O aspecto das glandulas dos vermes viventes e das preparações totais difere muito do nos cortes, em que, evidentemente, a secreção ficou completamente dissolvida. Esta é granulosa e racimiforme, pertencendo cada trato de secreção a um dos 6 núcleos (n) periféricos, situados no fundo da glândula. As glândulas teem fino envoltório muscular e desembocam na base da bainha (d). Retractores (j) da tromba inserem-se na ponta posterior do eixo proboscidial. 
No cérebro (c) ressalta-se a grande quantidade de células ganglionares, que revestem, ao que parece, os quatro tratos nervosos anteriores que saem do cérebro.

A posição da faringe (f) corresponde à em Sch. diplorchis. Concordam ainda o lume triangular do órgão, no corte transversal e a ausência de núcleos na bolsa e ao redor do lume. Faltam, porém, na espécie presente, os espessamentos epiteliais da bolsa (Meixner 1928, f. 9, ew) e as glândulas cianófilas faríngeas. A orla abocanhadora da faringe de Sch. martæ é cuticularizada ; os músculos longitudinais internos são fortes ; os radiais, fracos. As massas da secreção eosinófila preenchem quasi tôda a faringe. $O$ intestino (i), destituido de lume, contém células claviformes de Minot (Fig. 61, $\mathrm{m})$, ao redor da entrada intestinal e ainda em outros pontos da região anterior, mas não na posterior, que é, no total, reduzida pelos órgãos reprodutivos volumosos.

Os testículos (t) são ventrais e compõem-se de 6-8 ou mais folículos, juxtapostos e sucessivos, no plano mediano. O mesmo folículo pode abrigar várias fases da espermatogênese. Os testículos começam a certa distância do cérebro (c) e atingem a faringe (f). Imediatamente atrás desta aparecem duas largas vesículas seminais (s), de percurso sinuoso, que desembocam separadamente na vesícula (Fig. $66, \mathrm{r}$ ) ental da bolsa do cirro (z). A vesícula aludida tem carater de reservatório da secreção granulosa. A bolsa do cirro é musculosa e contém alguns núcleos (n) internos, a saber, 6 ao redor das desembocaduras das vesículas seminais e outros, perto do septo que separa o cône ectal da bolsa da vesícula granulorum. O duto ejaculatório apresenta-se como cirro (p), provido de finas cerdas fracamente basófilas, mais nítidas no verme vivente que nos cortes. $\mathrm{O}$ comprimento do cirro é de $0,05 \mathrm{~mm}$. ; o órgão estreita-se para fora, onde se ressalta da bolsa e se projeta para dentro do átrio (a).

Os vitelários (v) são laterais e começam, aproximadamente, ao nível do bordo posterior do cérebro (c). Estendem-se, nos dois lados do corpo, para trás, até além do gonóporo (g). Aí encurvam-se em direção mediana, estreitam-se e formam vitelodutos (vi). Estes desembocam, juntamente com o ovário (o), no canal genital feminino (y), de parede tênue. A posição do ovário impar, em relação ao gonóporo, varia muito. A gônada situa-se uma vez anteriormente ao poro, outra vez, posteriormente, apesar das duas ligações dos dois órgãos, constituidas pelo canal feminino (y) e pela via copulatória $(\mathrm{u}, \mathrm{w}, \mathrm{x})$. A última começa com a vagina $(\mathrm{u})$, comprida e ampla, de parede grossa, sem núcleos. Tinge-se, nos cortes, com o mesmo tom acastanhado-preto exibido pela membrana basilar. Evidentemente, trata-se, como na vagina de Trapichorhynchus tapes Marcus (1949, p. 36) de uma camada externa protoplasmática, um epitélio sem núcleos, que produz uma cutícula. Esta, por sua vez, emite vilosidades internas, plasmáticas. A vagina dirige-se para diante, quasi até à altura da vesícula granulorum. Aí encurva-se para trás, desembocando na bursa seminal (w), de parede frouxa. Um canal estreito, mas de paredes distintas, cuticulares, o duto espermático $(\mathrm{x})$, estabelece a comunicação entre a bursa e o ovócito mais crescido do ovário (o). Na desembocadura do duto espermático notam-se dois pequenos tufos de glândulas (ev), os únicos elementos talvez comparáveis com glâdulas argamassadoras ou glândulas da casca. Tão pouco quão a secreção das glândulas proboscidiais reconhece-se a destas glândulas nos cortes. O 
gonóporo (g) possue divaricadores e constrictores, mas é desprovido de glândulas.

Ocorrência : Cananea, ca. de $200 \mathrm{~km}$. ao sudoeste de Santos, em areia lodosa e de salinidade inferior à do mar aberto. Ca. de 30 exemplares foram vistos. Durante 8 semanas viveram os vermes em um aquário não arejado.

$\mathrm{O}$ nome da espécie refere-se à colecionadora da areia, a nossa estimada colaboradora, Sra. Dra. D. Marta Vannuccr.

\section{Discussão de Schizorhynchoides martæ}

A indicação "órgão copulador masculino com estilete cuticular" que se encontra na diagnose da família Schizorhynchidæ, formulada por Meixner (1928, p. 237), deve ser suprimida, pois Trapichorhynchus tapes Marcus (1949, p. 34) possue órgão masculino inerme e Schizorhynchoides martæ, um cirro. A diagnose aludida contém ainda os dizeres "testículos pares" A espécie presente, porém, não permite distinguir testículos direitos e esquerdos. Apresenta-se, destarte, a alternativa de introduzir uma nova família ou de ampliar a diagnose das Schizorhynchidæ. Preferimos acrescentar à passagem de Meixner as palavras "ou com testículos foliculares, múltiplos, ventro-medianos", pelas razões seguintes : Até agora, as famílias dos Kalyptorhynchia Schizorhynchia foram separadas por caracteres da tromba. Além disso, há duas espécies das Schizorhynchidæ com testículos subdivididos em dois, de cada lado, a saber, Proschizorhynchus atopus e Schizorhynchoides diplorchis Mx.. Nestas duas espécies, os dois testículos direitos situam-se um pouco mais para diante que os esquerdos, talvez porque o corpo filiforme impossibilite simetria completa. A posição mediana dos testículos múltiplos de Schizorhynchoides martæ torna-se, com isto, menos estranha.

Se parecer aceitável incluir a espécie presente nas Schizorhynchidæ, apenas os dois gêneros Schizorhynchus e Schizorhynchoides, com faringe na metade posterior do corpo, entram em discussão. Schizorhynchus com testículos indivisos afasta-se mais da forma aqui em mãos que Schizorhynchoides. Sch. diplorchis, o tipo dêste gênero, é verdade, possue vagina externa. Mas, Meixner $(1938$, f. 67$)$ incluiu færoeensis, com vagina atrial, no gênero Proschizorhynchus, apesar de o tipo, $P$. oculatus, possuir vagina externa. Assim, parece viável reunir, genericamente, Schizorhynchoides diplorchis e Sch. martæ.

\section{Ordo : Holocoela Graff (1904-08, p. 2010, 2504, 2548)}

(Cummulata Reisinger 1924, p. 147 ; Prolecithophora Karling 1940, p. 217, 231)

\section{Subordo : Combinata Karling (1940, p. 231)}

\section{Sectio : Combinata Opisthoporata Reisinger (1924, p. 148)}

No sistema de Karling foram os Allœocœla fragmentados. Os Lecithoepitheliata Reisinger (l. c.) e os Holocœla figuram como Ordens e os Metamerata Reisinger (1. c.) (Proseriata Meixner 1938, p. 6, 142) como Subordem Proseriata (veja Karling 1940, p. 227) dos Seriata, cuja outra Subordem são os Tricladida.

A Ordem Holocœla abrange duas Subordens, Combinata e Separata, os últimos com as famílias : Plagiostomidæ, Multipeniatidæ, Baicalarctiidæ, 
Gastropharyngidæ. Reisinger (l. c.) distinguiu, entre os Combinata, dois grupos de famílias, os Proporata e os Opisthoporata, cuja separação é útil para a primeira orientação. Sem esquecer a aproximação das Pseudostomidæ, que são Proporata, às Cylindrostomidæ, que são Opisthoporata (Karling 1940, p. 213 e seg., 240), apresentamos a chave seguinte dos Opisthoporata, i. é, dos Holocœla com orifício oro-genital (Combinata) situado na parte posterior do corpo:

1 Cílios restritos à face ventral trichina Calandruccio 1897)

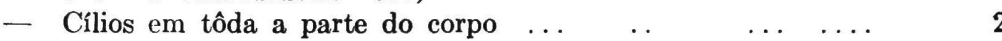

2 Esôfago curto, tubular $\ldots \ldots \ldots \ldots$... 3 (Cylindrostomidæ)

- Esôfago comprido, ectalmente tubular, entalmente saculiforme $\quad \ldots . \quad \ldots . \ldots . \quad 8$ (Scleraulophoridæ)

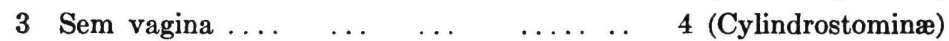

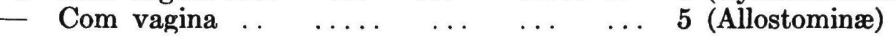

4 Ovário (par ou impar) post-cerebral ; desembocadura do ovoviteloduto caudalmente ao penis. . . . .Cylindrostoma Örsted 1845

- Ovário impar, pré-cerebral ; desembocadura do ovoviteloduto rostralmente ao penis... $\quad . . \quad$ Pregermarium Stirewalt, Ferguson \& Kepner 1942

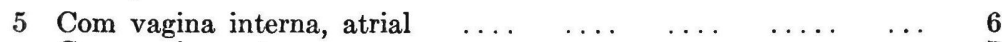

- Com vagina externa
-

6 Duto espermático (palheta da bursa) com lamelas cuticulares; sem olhos ..... Euxinia Graff 1911

- Duto espermático sem lamelas cuticulares; com 2 pares de olhos .. ... Monoophorum Böhmig 1890

7 Dutos espermáticos pares ... ... Allostoma Van Beneden 1861

- Duto espermático impar .. . . Enterostomula Reisinger 1926

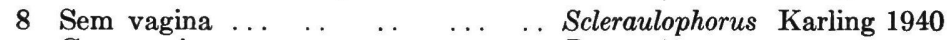

- Com vagina .. $\quad \ldots . \quad \ldots \quad \ldots . .$. Rosmarium, gen. nov.

A supressão das Allostominæ Bresslau (1933, p. 278), proposta por Karling (1940, p. 215), não foi adotada aquí, pois a presença de uma vagina, seja atrial ou externa, separa a entidade suficientemente das Cylindrostominæ. O achado de uma espécie com esôfago do tipo de Scleraulophorus, mas provida de vagina, mostra o paralelismo das estruturas femininas em Cylindrostomidæ e Scleraulophoridæ e aconselha considerar as Scleraulophorinæ de Karling como família. Urastoma cyprinæ (Graff), incluido no gênero Cylindrostoma por Reisinger (1924, p. 138 ; 1926, p. 444), mantemos, com Karling (1940, p. 214), à parte.

\section{Família : Scleraulophorida}

\section{Rosmarium, gen. nov.}

Scleraulophoridæ com quatro olhos, um único sulco ciliado, vesículas seminais pares e com penis. O ovário é impar. Vagina atrial presente.

Tipo do gênero : Rosmarium evelinæ, spec. nov.

Os caracteres de Rosmarium diferem consideravelmente dos de Scleraulophorus, sem olhos, sem penis e sem vagina, com dois sulcos ciliados, vesícula seminal impar e ovários pares.

A configuração singular do esôfago, sem paralelo entre os Turbelários (Karling 1940, p. 58), justifica a reunião dos dois gêneros na mesma família. 


\section{Rosmarium evelina, spec. nov. (Figs. 67-69)}

Os 4 vermes presentes foram identificados sómente em cortes seriados feitos de Holocoela Opisthoporata fixados em comum, de maneira que a forma e as medidas puderam ser depreendidas apenas de reconstruções. Os animais são arredondados, caudalmente algo cuspidatos, e teem a sua largura máxima atrás do meio. O comprimento é de $0,2 \mathrm{~mm}$.; a largura e a altura (direção dorso-ventral) são de $0,14 \mathrm{~mm}$. De elementos pigmentados reconhecem-se sómente os cálices pretos dos quatro olhos.

O sulco ciliado (Fig. 68,w), apenas ventralmente desenvolvido, dista 12 micra da desembocadura (j) das glândulas cefálicas e acusa comprimento de 50 micra. Na fosseta cefálica (j) abrem-se os feixes das glândulas frontais (h) em comum, havendo um dorsal eritrófilo e outro, ventral, cianófilo. Das glândulas cutâneas restantes são as cianófilas maiores e muito mais numerosas que as eritrófilas. Volumosas glândulas argamassadoras (g), de secreção alaranjada, entremeiam-se com as cutâneas azuis, ao redor do orifício oro-genital (b).

O comprimento (7 micra) dos cílios locomotores ultrapassa a altura da epiderme ( 5 micra). Os limites das células epidérmicas não se reconhecem ; os núcleos são intra-epiteliais. Muitas vezes são de tal modo envolvidos pela secreção azul das glândulas cutâneas que se reconhecem dificilmente. A membrana basilar é muito grossa (2 micra), como em Scleraulophorus cephalatus. Ao redor da fosseta cefálica é a epiderme mais alta $(7,5$ micra) e os cílios são mais compridos (11 micra) que no corpo restante (veja Fig. 69). As fibras da musculatura cutânea anelar são nítidas e separadas umas das outras ; a musculatura longitudinal do ventre é mais grossa (4 micra) que a do dorso (2 micra).

A cápsula do cérebro (c) é tênue. A forma do cérebro modificou-se, possivelmente, pela contração no momento da fixação ; o comprimento é de 30 micra ; as duas outras direções são de 46 micra. Estas medidas mostram ser o cérebro de Rosmarium evelinæ relativamente grande, como o de Scleraulophorus cephalatus Karling (1940, p. 149). Em oposição a este, desprovido de olhos, ocorrem na espécie presente, os 4 olhos típicos dos Holocoela Combinata, 2 anteriores, simples e 2 posteriores, duplos.

A distância entre o orifício oro-genital (b) e a extremidade caudal iguala a um sexto do comprimento do corpo. Em direção dorsal estende-se, dêste orifício, a bolsa faríngea (Fig. 69,k), que é profunda e circunda toda a faringe (f). Esta pertence ao tipo "plicatus" A bolsa é pobre em núcleos ; a faringe, sem êstes, afora alguns situados no parênquima ental do órgão. Os epitélios faríngeos são destituidos de cílios, em oposição a $S$. cephalatus (Karling 1940, p. 57). A sequência da musculatura é a mesma como nesta espécie, seguindo, de fora para dentro, epitélio externo, musculatura anelar, musculatura longitudinal, parênquima, musculatura longitudinal, musculatura anelar, epitélio interno. As fibras anelares internas são enormes; as outras, fracas. Os citosomas das glândulas faríngeas situam-se fora da faringe ; as desembocaduras delas circundam a bôca faríngea. O lume da faringe é de 20 micra, na direção dextro-sinistral; na ântero-posterior, é menor.

Entalmente à faringe segue o trecho tubuloso do esôfago (Fig. 68, e) e, mais para dentro, o saculiforme (d), em cuja parede se situam, provavelmente, os corpos das glândulas faríngeas. Mas os cortes sagitais, até agora 
disponíveis, não permitem a análise histológica dos dois trechos esofágicos, que não se situam no plano mediano, mas dobram-se obliquamente para o lado (Fig. 68). A forma da parte dilatada do esôfago parece-se muito com a de $S$. cephalatus nas figuras 5 B e 5 C de Karling (1940, p. 56, oes 2). As células intestinais, altas ou baixas conforme o estado da digestão, formam um epitélio homogêneo. Diatomáceas foram encontradas como conteudo intestinal.

Os testículos (x) são pequenos órgãos, como em S. cephalatus, e, como aí, situados ântero-lateral e dorsalmente ao cérebro. Dutos eferentes preformados parecem ausentes, como em $S$. cephalatus. Em oposição a êste, existem duas vesículas seminais (s) volumosas e dispostas simétricamente, de cada lado do plano mediano. Os espermatozóides maduros contidos nas vesículas são pobres em cromatina, ricos em citoplasma. Das vesículas, os espérmios passam à vesícula granulorum (r), um órgão esférico, de parede musculosa. O epitélio que a reveste é formado por grandes células repletas de grumos de côr azul escura, nos cortes corados com hematoxilina-eosina. Secreção granulosa dêste tipo, pronunciadamente basófila, ocorre raramente entre os Turbelários. As células grânulo-secretoras (n) situam-se ao redor da calota ental da vesícula. Em Scleraulophorus cephalatus, a vesícula granulorum comunica-se com o átrio por meio de um poro, sem que haja órgão copulador. Em Rosmarium evelinæ, invagina-se uma papila penial (p) para dentro da vesícula. Este penis dobrado, sem núcleos e tênue, é separado do átrio (q) por uma bainha penial $(\mathrm{m})$, também sem núcleos. $\mathrm{O}$ epitélio atrial é nucleado e destituido de cílios.

Os vitelários (v) não teem túnica própria e são dorso-laterais. Flanqueiam o intestino (i) que atinge o integumento dorsal na região mediana. Dorsal e ventralmente ao cérebro reunem-se os vitelários. Caudalmente ao intestino são ligados pelo ovário (o) mediano, sendo os vitelários contíguos com as zonas germinativas ováricas direita e esquerda. De cada lado do corpo continua um alongamento caudal dos vitelários até além da vagina, aproximando-se às glândulas da casca (a) vaginais. Estes alongamentos cilíndricos, que funcionam como ovovitelodutos (vi), desembocam, vindos dos dois lados, na vagina (u), perto do orifício atrial desta. A vagina corre do átrio à zona de crescimento do ovário, no plano mediano. É um tubo de parede grossa, sem núcleos e sem cílios.

Ocorrência: Ilha de São Sebastião, entre algas um pouco acima da linha da vasante ; 4 exemplares em junho de 1949.

\section{Família : Cylindrostomidx Reisinger (1924, p. 148) \\ Genus : Cylindrostoma (Örsted 1845, p. 416 ; Reisinger 1926, p. 444) Cylindrostoma netsicum, spec. nov. (Figs. 70-72)}

Os vermes são muito semelhantes a Enterostomula evelinæ Marcus (1948, p. 138), espécie da sua fauna acompanhadora. São pequenos, pois o menor exemplar acusa, nos cortes apenas $0,11 \mathrm{~mm}$., ao comprido, inclusive os cílios anteriores e posteriores. O maior exemplar cortado não ultrapassou $0,35 \mathrm{~mm}$. de comprimento. Vermes viventes são algo mais longos e, por outro lado, não tão altos e grossos ( $0,24 \mathrm{~mm}$., nos cortes). Quanto à forma, apresentam-se anteriormente arredondados e posteriormente um pouco caudatos. O 
sulco ciliado, regular nas Cylindrostomidæ, inexiste, como foi verificado nos animais viventes e nos cortes. A côr do corpo é amarela-clara ; a do intestino, tirante a acastanhado. Os cálices ópticos são pretos.

As glândulas são frontais (cefálicas), ventrais e caudais ; o dorso carece de glândulas. Os dutos das glândulas frontais (Fig. 70,h), de secreção eritrófila, reunem-se em pequenos grupos (e) que se abrem na face anterior, separados uns dos outros. Concentração maior há nas glândulas cianófilas ventrais (j), cujos dutos desembocam em uma concavidade de diâmetro de $0,022 \mathrm{~mm}$. O complexo das glândulas ventrais existe já em vermes jovens, sem gônadas. Numerosas glândulas eritrófilas ocorrem no ventre (y), em redor do orifício oro-genital (b) e na região caudal (z).

Os núcleos da epiderme são aprofundados. Os cílios locomotores que são compridos (6 micra) batem em ondas sincrônicas, como se depreende de cortes transversais, em que a superfície lembra uma roda denteada. Limites inter-celulares não se observam na epiderme, cujo plasma é estriado verticalmente. A camada epidérmica basilar é mais densa que a superficial. A membrana basilar é relativamente grossa. Dos músculos cutâneos são as fibras anelares finas e as longitudinais mais tênues ainda, quasi incognoscíveis. A secreção vermelha, das glândulas ventrais, acima mencionadas (y), aparece em alguns cortes como extensamente derramada ao longo do ventre.

O cérebro (e) é envolvido por uma cápsula e situa-se a pequena distância da face anterior, com certa aproximação ao ventre. A forma do cérebro, mais larga que comprida, pode ser condicionada pela contração do verme, no momento da conservação. Dentro da cápsula cerebral dispõem-se os 4 olhos, dois anteriores, simples, mais pertos um do outro, e dois posteriores, duplos, mais distantes entre si. As dimensões do cérebro de vermes pequenos e maiores diferem pouco. As medidas são, em micra : largura 30, altura 28, comprimento 20 .

$\mathrm{O}$ orifício oro-genital (b) equidista, aproximadamente, da fosseta ventral (k) e da extremidade caudal. Para êste orifício estreito convergem a faringe cilíndrica (f) e o átrio genital (a). A bolsa faríngea (x) é profunda e formada por epitélio fino, baixo, de núcleos intra-epiteliais. A faringe, um "pharynx plicatus", é externa e internamente revestida de cílios, dos quais os internos são compridos. Os núcleos dos epitélios faríngeos são aprofundados. Os músculos longitudinais externos e internos são sub-epiteliais ; os anelares, confinantes com o parênquima. Esta disposição corresponde à de C. vanhöffeni Reis. e C. gaussi Reis. Fibras radiais muito finas ocorrem. Músculos fixadores e locomotores que se originam no integumento do corpo atravessam o intestino e inserem-se no fundo da bolsa faríngea. O anel nervoso localiza-se na parte externa da faringe. Os citosomas das glândulas são, na sua maioria, extra-faríngeos, mas todos desembocam na orla livre da faringe, entre os epitélios externo e interno.

$\mathrm{O}$ revestimento interno da faringe projeta-se tubiformemente no lume estreito do intestino (i). Este ocupa sómente um pequeno espaço do corpo ; o seu epitélio é alto, de limites inter-celulares indistintos, mas separado dos órgãos adjacentes por grossa membrana basilar. Os únicos organismos ingeridos por nossos vermes foram algumas Diatomáceas.

Os testículos (Fig. 71,t) dispostos um de cada lado do cérebro (c) são envolvidos por túnica própria, como na maioria das Cylindrostomidæ. A 
túnica alonga-se para trás, formando os dutos eferentes (d). Estes encurvam-se em direção medial e dilatam-se. Nas vesículas seminais (s) assim originadas veem-se feixes compridos de espermatozóides. As duas vesículas reunem-se, constituindo o duto seminal que tem forma de pequena ampola. $\mathrm{O}$ trecho seguinte, o reservatório da secreção granulosa (q), é globoso e recebe a secreção das glândulas grânulo-secretoras, entremeiadas com as faríngeas. Para dentro do reservatório proemina o curto penis (p) no estado invaginado. Glândulas peniais $(r)$ eliminam a secreção eritrófila através da parede grossa do duto ejaculatório. Bainha penial não ocorre. A parte ental do átrio (a), que poderia ser chamada de átrio masculino, é espaçosa e revestida de altas células ciliadas.

Os vitelários (v), cuja configuração se vê na Fig. 72, são sacos látero-dorsais, ligados dorsal, anterior e posteriormente. Os ovários (Fig. 71, o) dispõem-se nos dois lados da faringe (f), dentro da túnica dos vitelários. Quanto à topografia, poder-se-ia falar em ovários e vitelários, mas anatomicamente trata-se de germovitelários. Espermatozóides alheios (w), quer dizer, adquiridos na copulação, encontram-se entre os gonócitos femininos e na proximidade dêstes, no germovitelário. O envoltório de cada germovitelário espessa-se em direção caudal e forma os dois ovovitelodutos. Estes não são ciliados. Encurvam-se ventralmente e reunem-se imediatamente antes da sua entrada no átrio (a). O orifício do duto comum abre-se no meio de uma proeminência formada pelas desembocaduras das glândulas argamassadoras $(\mathrm{m})$.

Ocorrência : Ilha de São Sebastião, numerosos exemplares entre Sargassum stenophyllum, juntamente com Microstomum gabriellæ Marc., Enterostomula evelinæ Marc. e outros Turbelários. As algas foram colhidas entre as linhas da vasante regular e da mais baixa. Dois vermes de Cylindrostoma netsicum foram verificados no parênquima digestivo de Amphiscolops sargassi Hym.

\section{Discussão de Cylindrostoma netsicum}

Desde Jensen (1878, p. 61), o nome do gênero aparece, em várias publicações, na forma "Cylindrostomum", mas esta inovação não se justifica. C. vanhöffeni Reinsinger (1926, p. 445) distingue-se da espécie presente pela faringe horizontalmente disposta, inserida anteriormente ao meio do corpo, e pelo grande órgão masculino que é bulbiforme. C. gaussi Reisinger (1926, p. 448) possue vesícula seminal impar, de enormes dimensões. A vesícula granulorum de gaussi compõe-se de dois compartimentos. O menor é o ental, que Reisinger chamou de "äussere", por que se situa fora do bulbo copulatório. O maior é o ectal, que se encontra dentro do bulbo. C. monotrochum (Graff), re-estudado por Ritter-Záhony (1908), distingue-se de netsicum pelos núcleos intra-epiteliais da epiderme e pela abundância das glândulas cutâneas em todo o integumento. Os cílios faríngeos internos e externos possuem comprimento igual. Os ovários, metidos entre os testículos e o intestino, situam-se mais para diante que em $C$. netsicum. Os testículos não são, como nêste, compactos, mas há duas massas testiculares num dos lados do corpo ; uma, no outro. As vesículas seminais, compridas em C. netsicum, são globosas em monotrochum, que ainda possue sulco ciliado. Este ocorre também em $C$. elongatum Lev. O pigmento reticulado do parênquima e as algas simbiônticas das células intestinais separam zooxanthella (Graff) de netsicum. 
Jones (1939, p. 35) incluiu Monoophorum triste Graff (1911, p. 81) no gênero Cylindrostoma. A espécie possue muitos testículos e vesícula seminal impar. Diferem, além disso, a forma da vesícula granulorum e a do penis da dos órgãos correspondentes de $C$. netsicum.

\section{Cylindrostoma ibeenum, spec. nov. (Fig. 73-77)}

Os vermes ocorrem juntamente com Cylindrostoma netsicum e são ainda menores, pois o comprimento dos exemplares conservados, medidos em óleo de cravo, atinge, ao máximo, $0,22 \mathrm{~mm}$., sendo o diâmetro de $0,14 \mathrm{~mm}$. O corpo (Fig. 73) é anteriormente arredondado; posteriormente provido de cauda curta. O sulco ciliado (Fig. $75, \mathrm{~h}$ ) situa-se um pouco antes do cérebro (c) e é nítido ventral e lateralmente ; mais para o dorso, extingue-se por completo. Os vermes são brancos com numerosas glândulas amarelas. Destaca-se, além disso, o conteudo intestinal escuro, em alguns exemplares. Os 4 cálices oculares são pretos.

As glândulas, amarelas no verme vivente, são aprofundadas e de secreção grumosa, cianófila. As glândulas cefálicas (r) formam um órgão frontal, composto de glândulas eritrófilas, centrais, e cianófilas, periféricas. Os citosomas das últimas estendem-se até além do cérebro (c) para trás ; os das eritrófilas são mais curtos. As desembocaduras (e) dos dois tipos apresentam-se concentradas. Glândulas eritrófilas, do carater das argamassadoras (m), circundam o orifício oro-genital (b).

Os cílios locomotores são muito compridos (6-9 micra); rabditos não ocorrem. Os núcleos epidérmicos são intra-epiteliais ; o citoplasma é colunar. Os limites inter-celulares da epiderme não se reconhecem, mesmo em cortes tangenciais. A membrana basilar é bastante grossa, assim como a musculatura cutânea. A grossura desta deve-se ao seu componente anelar, cujas fibras são finas, mas muito numerosas.

O cérebro (c), envolvido por cápsula, aproxima-se ao ventre e é separado da extremidade anterior pelos pacotes das glândulas frontais (r). Os olhos são intra-capsulares (Fig. 74) e correspondem aos de Cylindrostoma netsicum.

O orifício oro-genital (b) encontra-se perto da extremidade caudal. O ovoviteloduto $(u)$ desemboca na região ectal do átrio masculino (a), ao nível da reunião dêste com a bolsa faríngea (x). Esta é profunda, em comparação com o corpo faríngeo, e revestida por epitélio muito baixo, de núcleos (Fig. $76, \mathrm{k}$ ) ressaltados. A faringe (f) é largamente ovóide e provida de curtos ćlios externos e internos. Pertence ao tipo do "pharynx plicatus", mas difere da faringe de Cylindrostoma netsicum em pormenores dos epitélios e da musculatura. Os núcleos epiteliais faríngeos situam-se extra-faringealmente, como em Enterostomula dura (Karling 1940, p. 47) e E. evelinæ (Marcus 1948, p. 139-140). Os músculos correspondem ao primeiro tipo das Cylindrostomidæ descrito por Karling (l. c., p. 49), pois de fora para dentro seguem : epitélio externo, músculos anelares (j), músculos longitudinais (n), parênquima com os dutos das glândulas, músculos anelares (j), músculos longitudinais (n) e epitélio interno. As camadas mais grossas são a musculatura longitudinal externa e anelar interna. Os citosomas das glândulas faríngeas (g), eritrófilas e cianófilas, desembocam na orla livre da faringe. 
O lume faríngeo dilata-se na entrada do intestino (Fig. 75), mas êste mesmo (i) apresenta-se, em todos os exemplares examinados, sem lume e sem limites inter-celulares nítidos. Contem Diatomáceas (Fig. 74) e estende-se mais nas direções dorso-ventral e dextro-sinistral do que em direção ântero-posterior.

Os 2-6 pequenos folículos testiculares (t) situam-se látero-dorsalmente ou, em alguns casos, dorso-medianamente ao cérebro (c). 'Túnica testicular falta. Os cromosomas, que se reconhecem, p. e., nas divisões das espermatogônias, são 12 ; 10 menores e 2 maiores. Os dutos eferentes (Fig. 77,d) são destituidos de músculos; desembocam, sem reunião prévia, no ápice da vesícula (s) que chamamos "vesícula comum", pois contém espérmios e, na parte ectal, células (q), provavelmente armazenadoras de secreção granulosa. As próprias glândulas grânulo-secretoras não conseguimos distinguir das glândulas peniais (w), devido à pequenez das estruturas em questão. A parede da vesícula comum é musculosa. O penis (p) da Fig. 77 é maximamente retraido e separado do átrio (a) pela bainha penial (y). Em outros exemplares, a papila penial projeta-se para o átrio (Fig. 74), e a bainha forma apenas uma dobra anelar inconspícua no ponto, em que o átrio coere com a vesícula. Para êste ponto convergem os dutos das glândulas peniais (w), de secreção eritrófila. O átrio masculino (a), na terminologia de Karling (1940, p. 203), canal genital masculino, é tubuloso e ciliado.

Os vitelários (v) são órgãos pares, laterais. Reunem-se dorsalmente ao cérebro (c) e à faringe (f). A última reunião é formada pelo trecho germinativo impar das gônadas femininas, o ovário (Fig. 73,o), cujas zonas germinativas se originam na extremidade caudal de cada um dos vitelários. Túnica vitelárica e ovárica inexistem. Os ovócitos crescidos já são inseminados no ovário. O ovoviteloduto impar (u) corre no plano mediano em direção caudal e ventral. $\mathrm{O}$ seu último trecho torna-se canal genital feminino, pois recebe a secreção das glândulas argamassadoras (m) antes da sua desembocadura no átrio. Outro grupo destas glândulas circunda o orifício oro-genital (b).

Ocorrência : Entre algas crescidas nas pedras da práia da ilha de São Sebastião, ca. de 20 exemplares, juntamente com Cylindrostoma netsicum, Enterostomula evelinæ Marc., espécies de Microstomum, Plagiostomum e outros gêneros.

\section{Discussão de Cylindrostoma ibeenum}

Todas as espécies de Cylindrostoma mencionadas na discussão de $C$. netsicum possuem ovários pares. Segundo Graff (1913, p. 407), a única excepção talvez existente é $C$. elongatum Camble (1893, p. 385 t. 41 f. 19). Esta espécie caracteriza-se pelo corpo muito alongado e estreito, por pseudorabditos, bordo da faringe crenulado, secreção granulosa disposta radialmente e penis piriforme, cuja porção distal é nitidamente atenuada em comparação com o bulbo proximal.

\section{Genus : Monoophorum Böhmig (1890, p. 469)}

\section{Monoophorum tigacum, spec. nov. (Figs. 78-82)}

O único verme disponível é, nos cortes, de 0,25 mm., ao comprido e de largura de $0,15 \mathrm{~mm}$. A forma é ovóide, anteriormente mais arredondada, posteriormente mais cuspidata. A fenda ciliada ventral (Fig. 79,r), provida 
de glândulas eritrófilas (j), estende-se nos dois lados até ao nível do cérebro (c). As glândulas frontais (e), também eritrófilas, desembocam reunidas com um poro comum (h).

Os núcleos da epiderme (Fig. 82) são intra-epiteliais. Os cílios locomotores são compridos ; na epiderme ocorrem muitas glândulas (g) de secreção vermelha amarelada (coloração: hematoxilina-eosina). Rabditos ou formações semelhantes faltam. A membrana basilar é forte ; a musculatura cutânea, fina. Os 4 olhos apõem-se ao cérebro (c) que é circundado por cápsula espessa.

O orifício oro-genital (Fig. 79,b) é sub-terminal, ventral. Do orifício para dentro situam-se o átrio masculino (a), que é dorsal, e a bolsa externa da faringe (x), mais para diante. O epitélio da bolsa (Fig. 80) é nucleado. A faringe (f), curta e larga, projeta-se com dois terços do seu comprimento na bolsa. O tipo da faringe é o do "pharynx plicatus" Os núcleos dos epitélios faríngeos externo e interno são aprofundados, havendo cílios escassos apenas no interno. Os músculos anelares internos são fortes ; os outros, fracos, destacando-se na face externa ainda fibras radiais oblíquas desenhadas na Fig. 80. A bôca faríngea interna pode ser fechada por esfíncter grosso. O corpo faríngeo é entalmente delimitado por uma dobra, a bolsa faríngea interna, que lembra o órgão correspondente de Plicastoma (Marcus 1947 , t. 20 f. $90,92,94)$. Os citosomas das glândulas são extra-faríngeos ; as desembocaduras delas encontram-se na bôca faríngea externa. $\mathrm{O}$ anel nervoso (n) situa-se no terço ectal da faringe.

$\mathrm{O}$ alto epitélio do intestino (Fig. 79,i) segue imediatamente ao da bolsa faríngea interna. Algumas células claviformes de Minot (m) são espalhadas entre as células ressorventes. Clavas ocorrem também em $M$. ruseri Reisinger (1926, p. 450), mas, em geral, não são desenvolvidas nos Holocoela (Cumulata). Se o intestino não fosse estreitado pelos vitelários (v), seria mais largo que comprido.

Os testículos ( $\mathrm{t}$ ) são pré-cerebrais e ocupam um plano entre o ovário (o), mais dorsal, e as glândulas frontais (e), na sua maioria mais ventrais. Túnica própria testicular inexiste ; cada folículo é formado por células germinativas na mesma fase. Os grupos de células provindas da mesma espermatogônia (espermatogemas) foram re-encontrados (Marcus 1948, p. 140). Os dutos eferentes (d) dilatam-se dorsalmente à faringe, formando 2 vesículas seminais, de parede epitelial, nucleada, mas, evidentemente, sem músculos. Pela reunião destas vesículas accessorias origina-se a vesícula seminal principal (Fig. 81,s), cuja parede é musculosa. O penis (p) apresenta-se como curta papila cônica, com nucleos, cuja base abriga a secreção granulosa (q). A bainha penial (z) é um pequeno anel epitelial, sem parênquima. Cílios curtos encontram-se no trecho ectal do duto ejaculatório, na face externa da papila penial e na parede do átrio (a).

O ovário (o) que é impar situa-se entre as extremidades anteriores dos vitelários (v) e dorsalmente aos testículos (t). Com os últimos confina a zona germinativa ovárica (Fig. 82). A túnica própria dos vitelarios envolve também o ovário. Os vitelários são órgãos laterais, reunidos no meio, debaixo do cérebro. Os ovos que se soltam do ovário passam pelos vitelários e entram no átrio (Fig. 81,a). Um tufo de glândulas, talvez glândulas da casca (k), derrama a sua secreção eritrófila, na desembocadura dos ovovitelodutos, no átrio. Como ovovitelodutos designamos a parte posterior estreitada e 
pérvia dos vitelários, cuja túnica já foi mencionada como manto comum da gônada feminina inteira, dos germovitelários. Outras glândulas eosinófilas, provavelmente argamassadoras (l), existem ao redor do orifício oro-genital (b).

A vagina (u) é curta $(0,02 \mathrm{~mm}$.) e sobe dorso-caudalmente do átrio. Ela conduz espermatozóides alheios à bursa volumosa (w), em que massas de espérmios se aglomeram (Fig. 79). No lume da calota interna da bursa começa o duto espermático cuticular (y), cujo início ectal, a palheta da bursa, é subdividido em túbulos paralelos, lembrando o órgão correspondente de $M$ striatum (Böhmig 1890, p. 446 t. 19, f. 10, 11). Para diante continua o duto espermático com numerosas alças e atinge o ovário. $\mathrm{O}$ orifício ental do duto aproxima-se dos ovócitos mais crescidos situados no lado posterior do ovário.

Ocorrência: Ilha de São Sebastião, entre algas da linha da vasante regular; junho de 1949.

\section{Discussão de Monoophorum tigacum}

A espécie distingue-se de $M$. striatum (Graff) e $M$. ruseri Reis. pela ausência de rabditos e pela presença da fosseta cefálica (h ; "Kopfgrube"), onde as glândulas frontais desembocam em comum. Em $M$. tigacum é a faringe mais larga que comprida, dando-se o contrário em striatum e ruseri. Nos últimos equidista o ovário, aproximadamente, dos polos anteriores e posterior do corpo. A bursa de striatum aproxima-se do ovário, sendo o duto espermático correspondentemente curto e a vagina, comprida. Em ruseri encontramos vagina curta e duto comprido, mas êste não forma alças, nem começa com palheta subdividida em tubinhos. O penis de ruseri é muito singular; o de striatum corresponde, por princípio, ao da espécie presente. Tanto em striatum quanto em ruseri reunem-se os trechos terminais dos vitelários (germovitelários, Böhmig 1890, p. 445). Em ruseri existe até reunião dos dois ovovitelodutos, os prolongamentos da túnica germo-vitelárica e, destarte, um ovoviteloduto comum (duto glandular, Reisinger 1926, p. 452), que recebe as glândulas da casca.

\section{Família : Plagiostomidæ Graff $(1907$, p. $2010 ； 1908$, p. 2549)}

\section{Puzostoma, gen. nov.}

Plagiostomidæ cujas gônadas se compõem de dois ovariotestes e dois vitelários ; os ovariotestes são ligados à vesícula comum. A faringe do tipo "pharynx plicatus" é seguida pelo esôfago comprido, cuticularizado.

Tipo do gênero: Puzostoma evelinæx, spec. nov.

Bresslau (1933, p. 114) ainda escreveu: "as células germinativas dos Turbelários encontram-se sempre em gônadas separadas" A primeira excepção desta regra foi encontrada em Diopisthoporus longitubus Westblad (1940, p. 4), representante de uma família especial dos Acoela Opisthandropora. Nesta espécie, a parte anterior da gônada é um ovariotestis situado no plano mediano da metade anterior. Para trás, separam-se o testículo dorsal e o ovário ventral. Puzostoma evelinæ é o primeiro Turbelário, cujas gônadas são um par de ovariotestes completos. 
Grupos difusos em que as células germinativas dos dois sexos ocorrem em comum ("gemeinsame diffuse Keimlager") são frequentes entre os Acoela. Um único exemplo fornecem também os Turbellaria "coelata", em Prolecithoplana lutheri Karling (1940, p. 15). Neste caso, como nos Acoela em geral, não se trata de uma gônada saculiforme com túnica (Karling 1940, p. 21). Ao lado dos grupos mixtos impares, que são a regra, existem pares, ântero-laterais, em Polysolenoposthia porsildi, pertencente aos Acoela (An der Lan 1936, p. 309), mas pouco conhecida (Westblad 1948, p. 58).

Puzostoma pertence à família Plagiostomidæ, na vizinhança de Plicastoma Graff (1904-08, p. 2010, nota ; p. 2550 ; Marcus 1947, p. 154). Ovariotestes de uma forma dos Cumulata (Prolecithophora Karling) Separata não podem, sem delongas, ser relacionados com grupos germinativos difusos mixtos de um representante dos Cumulata Combinata, como é Prolecithoplana lutheri. Os grupos da última espécie são até menos diferenciados, porque abrangem ainda elementos vitelógenos.

$O$ esôfago de $P$. evelinæ lembra, de certo modo, o epitélio cuticularizado do intestino anterior intensamente dobrado de Plicastoma bimaculatum (Böhmig 1890, p. 399-400 t. 14 f. 9). Muitas Plagiostomidæ possuem bolsa faríngea interna, que pertence, histologicamente, à faringe (Böhmig 1914 , p. 24 ; Karling 1940 , p. 74 ; Marcus 1947, p. 155). Os esôfagos de Scleraulophorus cephalatus Karling (1940, p. 58) e de Prolecithoplana lutheri (ibid., p. 19) não são histologicamente semelhantes ao de Puzostoma, que é cuticularizado, de núcleos aprofundados, muito musculoso, e sem glândulas.

\section{Puzostoma evelinæ, spec. nov. (Fig. 83-88)}

Os vermes cujas particularidades se revelaram apenas depois da sua conservação, juntamente com Cylindrostomidæ e outras Plagiostomidæ, acusaram, nêste estado, comprimento de até $0,7 \mathrm{~mm}$. e largura de $0,4 \mathrm{~mm}$. Sulco ciliado não ocorre, como se evidenciou pela compressão de animais viventes e pelos cortes. A côr é cinzenta com largas faixas mais escuras, parcialmente coalescidas nos dois lados e separadas por regiões mais claras, de largura menor (Fig. 83). Uma faixa ventro-mediana é isenta de qualquer pigmentação. O pigmento ferrugíneo dos 6 cálices ópticos, situados um perto do outro na parte anterior do cérebro (Fig. 84,c), conserva-se nos cortes.

Apesar da fixação adequada com "Susa" quente, a epiderme apresentou-se dobrada nos cortes e, em muitos trechos, afastada do pigmento subjacente. Permite, todavia, reconhecer alguns núcleos intra-epiteliais e os cílios, cujo comprimento é menor que a altura das células. Pequenas clavas de pigmento (r) encontram-se na superfície da epiderme, sendo estas ligadas à rede subepitelial. Vacúolos entre as células, os espaços hialinos, dutos de glândulas com secreção eritrófila, e outros com cianófila, ocorrem na epiderme. Os núcleos das glândulas são aprofundados. Anterior e dorsalmente à bôca (b) desembocam reunidas as glândulas frontais (g), de secreção ígnea, nos cortes corados com hematoxilina-eosina. As células dêste volumoso órgão frontal estendem-se até além do cérebro (c) para trás.

A musculatura cutânea anelar é cerrada ; a longitudinal, muito fraca. Grânulos de pigmento vêem-se no parênquima e no epitélio do intestino (i). $\mathrm{O}$ cérebro (c) é mais largo que comprido e destituido de cápsula. De cada lado, há três olhos entre as células ganglionares que revestem a calota anterior do cérebro. 
A bôca (b) é ântero-ventral e desprovida do anel formado pela membrana basilar, conhecido de outras Plagiostomidæ (Marcus 1948, p. 143, 151). A bôca abre-se com tubo curto e largo na profunda bolsa faríngea, que atinge a raiz da faringe. Alguns núcleos notam-se na região anterior do epitélio fino da bolsa. A faringe (f), ora mais cônica, ora mais campaniforme, é revestida por epitélio não-ciliado, de núcleos aprofundados. As poucas glândulas são eritrófilas e desembocam na orla da faringe. Os músculos longitudinais, externos e internos, confinam com os epitélios ; os anelares, com o parênquima. A musculatura interna é grossa. A ausência de um septo que separe o parênquima faríngeo do parênquima circunjacente caracteriza a faringe como "pharynx plicatus"

O trecho seguinte, muito musculoso, é o esôfago (e), um largo tubo de paredes dobradas, evidentemente muito dilatável e revestido por cutícula. Esta é fornecida por células aprofundadas. A roseta de células relativamente grandes (m), na passagem do esôfago ao intestino (i), mostra-se, nos cortes, rosácea, mas não são clavas granulosas típicas. Segundo a nomenclatura de Hofsten (1918, p. 20), o esofago de Puzostoma evelinæ seria um "esôfago verdadeiro ectodérmico", diferente dos trechos entre faringe e intestino que se conhecem de outras Plagiostomidæ (Brandtner 1934, p. 112-113 ; Karling 1940, p. 74, 79).

O intestino (i) preenche toda a metade posterior do corpo, com excepção das regiões ocupadas pelos órgãos reprodutivos. Estes modificam os contornos do saco digestivo, entalhando-os irregularmente. No lume intestinal viu-se, uma vez, um pequeno Crustáceo. As células intestinais altas e destituidas de cílios carecem de limites distintos. Conteem numerosos nematocistos (n), de vários tipos, que não transmigram ao integumento como nas Microstomidæ, nos Polycladida e em Archimonocelis (Meixner 1938, p. 20).

Os ovariotestes (o) situam-se látero-caudalmente. São compactos e separados do parênquima por membrana fina, coerente com a parede da vesícula comum (Fig. 86,w). Ignora-se a origem desta membrana, como em geral a das túnicas das gônadas dos Turbelários (Reisinger 1926, p. 451-452). Entre as Plagiostomidæ e os Separata restantes constitue gônada com envoltório uma excepção (Karling 1940, p. 81, 90, 232). Núcleos não foram vistos na membrana dos ovariotestes de Puzostoma evelinæ. Os espermatozóides dirigem-se medialmente na gônada. Aí apresenta a parede da vesícula comum, de cada lado, uma interrupção, que permite a passagem dos gonócitos masculinos. Conhecemos êstes sómente nos cortes, em que se assemelham aos tipos desenhados de Plagiostomum porsildi Brandtner (1934, t. 1 f. 11) e $P$. acoluthum Marcus (1948, t. 9 f. 55). Teem forma de cenoura e carecem de apêndice flageliforme. Os trechos cromático e acromático não se distinguem, sendo ambos eosinófilos, como em Acmostomum dioicum (Karling 1940, p. 82).

A parede da vesícula comum (w) contém pigmento. O órgão é esférico e recebe a secreção das glândulas grânulo-secretoras (Fig. 87,x), que desembocam medialmente às comunicações da vesícula com os ovariotestes. A separação entre a vesícula e o saco distal (y) é completa. O órgão copulador corresponde ao tipo de $\mathrm{Pl}$. makropharynx Brdt. (Karling 1940, p. 88 f. 10 F no texto da p. 87). Sendo o penis da espécie presente mais curto que em makropharynx, presta-se para o confronto especialmente $P l$. hartmeyeri Weiss (1910, t. 15 f. 11-13), do mesmo tipo (Karling, l. c.). O epitélio do saco 
distal contém núcleos e secreção ; a superfície é irregular, como em Plicastoma norvegicum Karling (1940, p. 86 : "gerunzelt"). O penis invaginado (p) proemina no saco distal ; no epitélio grosso do duto ejaculatório entra a secreção eritrófila das glândulas peniais (z). A extremidade ectal do penis é circundada pela bainha (q), cujo parênquima é pigmentado. Núcleos ocorrem no epitélio da bainha e no do átrio (a). O gonóporo (k) encontra-se ventro-caudalmente, desembocando glândulas eritrófilas ao redor dêle (Fig. 88).

Os ovócitos dirigem-se, à medida do seu crescimento, sempre mais para as partes dorsal e rostral dos ovariotestes. Saem dêstes e localizam-se entre intestino (Fig. 85,i) e vitelário (v). Aí correm, no lado mediano dos vitelários, os vitelodutos ciliados (Fig. 88,u). Nestes entram os ovos, cuja fecundação deve realizar-se durante a sua migração dos ovariotestes para os ovovitelodutos. As vilosidades dos ovócitos em crescimento de Puzostoma evelinæx lembram as de $P l$. oyense Beauchamp $(1921$, p. 170) ou, mais ainda, as menores de Vorticeros auriculatum (Böhmig 1890, p. 327 t. 16 f. 13, 15, ps). A superfície de ovócitos jovens e a de completamente crescidos, os chamados óvulos, é lisa. Os dois ovovitelodutos reunem-se, constituindo o ovoviteloduto (ou duto) comum (d). Este entra no átrio (a) pela parede dorsal. Pacotes de glândulas argamassadoras (j) derramam a secreção eritrófila ao redor da desembocadura do ovoviteloduto comum.

Ocorrência : Ilha de São Sebastião, entre algas abaixo de linha da vasante regular. Ca. de 12 indivíduos, em abril de 1949 e vários em junho do mesmo ano.

\section{Ordo : Seriata Westblad $(1935$, p. 74 , nota) \\ Subordo : Proseriata Meixner (1938, p. 6)}

Família : Monocelididæ Hofsten (1907, p. 626)

Subfamília : Promonotinæ Marcus (1940, p. 37)

Genus : Promonotus Beklemischev (1927, p. 91)

Promonotus erinaceus, spec. nov. (Figs. 89-90)

O comprimento dos vermes maiores, medidos em óleo de cravo, é de $1,05 \mathrm{~mm}$. ; a largura, de $0,16 \mathrm{~mm}$. São incolores, sem olhos. A extremidade anterior é arredondada; a posterior, mais ou menos cuspidata e provida de papilas adesivas (h) que aí substituem os cílios, ausentes na cauda. O corpo é cilíndrico e dilata-se ao nível do cérebro (c). Esta dilatação varia conforme o estado alimentício do verme. A faringe (f) situa-se atrás do meio, e os órgãos copulatórios ocupam o centro da região post-faríngea, sem que atinjam a faringe ou a cauda. Se a extremidade posterior fôr contraida, a distância entre ela e os órgãos aludidos torna-se menor que na Fig. 89.

Os núcleos da epiderme são aprofundados. O comprimento dos cílios iguala ao diâmetro da camada cobertora inclusive os músculos cutâneos. Limites entre as células epidérmicas não se reconhecem. A membrana basilar é muito fina. Rabditos faltam. Secreção eritrófila atravessa a epiderme filiformemente, em todas as partes do corpo. Algumas glândulas cefálicas 
(g), de secreção cianófila, desembocam na extremidade anterior em um círculo. A secreção das papilas adesivas mantem-se incolor nos cortes corados com hematoxilina-eosina. A musculatura cutânea anelar é muito fina ; a longitudinal, bastante distinta.

O cérebro (c) não tem cápsula ; os seus elementos celulares são numerosos ; as fibras, o neuropilema, escassas. O estatocisto (e), pequeno e esférico, de diâmetro de 0,017-0,022 mm., é circundado completamente por células ganglionares cerebrais e mostra dois núcleos de células estatolitógenas. Os nervos ventro-laterais posteriores são fortes ; os nervos restantes, indistintos.

A faringe (f) dilata-se claviformemente da sua raiz à extremidade caudal. A posição da bôca (b) varia ; pode situar-se no limite entre o segundo e o último terço da faringe. $\mathrm{O}$ epitélio da faringe é ciliado nos lados externo e interno, sendo os núcleos todos aprofundados. A musculatura faríngea é fraca e corresponde, de resto, à da faringe de $P$ villacae Marc. As glândulas, de côr rósea e azul, desembocam sómente na orla livre da faringe, não no lume. $\mathrm{O}$ anel nervoso (n) encontra-se no terço ectal da faringe. A região ental tem carater de um esôfago, pois faltam aí os cílios, e alguns núcleos intra-epiteliais ocorrem.

As células claviformes de Minot (Fig. 90,m) são raras e irregularmente distribuidas no intestino (i). O parênquima pré-cerebral é vesiculoso, mas não corresponde à estrutura do intestino cefálico, como existe em outros Seriata. O intestino estende-se do cérebro até à região post-copulatória. Os órgãos copulatórios penetram no lume intestinal e são, aí, revestidos por uma lamela fina de tecido intestinal. Uma estrutura notável é o septo (z) na base da faringe. $\mathrm{E}$ formado por músculos locomotores e glândulas faríngeas e separa o intestino anterior e posterior, ligados por uma perfuração dorsal do septo.

Dois a seis folículos testiculares (Fig. 89,t) ocorrem de cada lado da região pré-faríngea. Cada folículo contém várias fases da espermatogênese e possue túnica própria. As cabeças dos espermatozóides são curtas ; as caudas, compridas e grossas. Os dutos eferentes não se reconhecem. A vesícula seminal (Fig. 90,s) é alongada e segurada por um ligamento suspensório (j) no meio da região post-faríngea. Um manto de 6 micra de grossura, constituido por músculos espiraladamente dispostos, circunda a vesícula, cujo comprimento é de $0,085 \mathrm{~mm}$. ; o diâmetro, de $0,04 \mathrm{~mm}$. A parte anterior e ectal da vesícula seminal poderia ser chamada vesícula da secreção granulosa (r), mas não é separada externamente da parte ental. Os núcleos situados anteriormente à vesícula granulorum pertencem às glândulas grânulo-secretoras ; os outros visíveis na Fig. 90, à musculatura. O trecho seguinte (d), o duto ejaculatório, é tubuloso e comprido (ca. de $0,07 \mathrm{~mm}$.). O seu diâmetro é de $0,012 \mathrm{~mm}$., inclusive a musculatura que o envolve. $O$ canal encurva-se para trás e para o lado ventral. O lume é revestido por uma camada côr de rosa, cuja natureza, cílios ou acúleos minúsculos, nem com imersão pôde ser definida. O canal termina circundado por um anel de núcleos. Para dentro do profundo átrio masculino (w), que é ciliado, projeta-se o penis (x), de base bulbosa, com acúleos e de tubo terminal mole. O revestimento interno do duto ejaculatório intrapenial é róseo, granuloso, e tem carater de secreção. Todo o penis é desprovido de núcleos. O átrio 
estende-se para trás e para o lado ventral, abrindo-se com o poro masculino $(p)$.

Os ovários (Fig. 89,o) são grandes, de $\mathbf{0 , 0 7} \mathrm{mm}$., ao comprido e de altura de $0,04 \mathrm{~mm}$. Situam-se anteriormente à faringe (f) e atrás dos testículos (t). Espermatozóides alheios ocorrem entre os ovócitos. Túnica própria celular circunda os ovários. Os vitelários (v) começam ao nível dos testículos, dorso-lateralmente a êstes. Passam nos dois lados da faringe e terminam à altura da calota caudal da vesícula seminal (s). Os ovovitelodutos (u) são canais grossos que correm perto do lado ventral e se reunem sómente atrás do átrio masculino. O poro feminino (q) dista $0,02 \mathrm{~mm}$. do masculino e é circundado por uma roseta de glândulas argamassadoras (a), de secreção eritrófila.

Ocorrência: Ilha de São Sebastião, na areia da região da desembocadura de um riacho, ca. de 30 exemplares colecionados com isca. A água da região indicada é doce, nas horas da vasante ; salobra durante a enchente.

\section{Discussão de Promonotus erinaceus}

Beklemischev (1927, p. 97) considera a porção estreita do órgão copulador de Promonotus orientalis e P. hyrcanus como "cirrus", comparando-o com o órgão correspondente de Archiloa rivularis Beauch. e da espécie hoje chamada Archilopsis unipunctata (Fabr.). Também Meixner (1943, p. 465) diz : "einen Cirrus wie die Promonotus-Arten" A meu vêr P. schultzei Mx. é a única espécie do gênero que possue um cirro verdadeiro, i. é, um duto ejaculatório (ou mais corretamente, canal genital masculino) tubuloso e evaginável, situado livremente dentro de uma cavidade especial, a bolsa do cirro. Esta ocorre, a julgar pela figura esquemática de Meixner (1943, f. 6 na p. 465), em $P$. schultzei. Unicamente nesta espécie existem ainda massas de células, ao redor dos ovovitelodutos, homologas a uma bursa anterior ou seminal. Com os caracteres indicados separa-se $P$. schultzei da espécie atual. $P$ villacae Marcus (1949, p. 39) tem átrio masculino muito curto, penis tubuloso e provido de acúleos ao longo de toda a sua extensão, ovários situados de cada lado da faringe e bôca mais posterior que $P$ erinaceus. A vesícula seminal alongada e o duto ejaculatório comprido entre a vesícula granulorum e o bulbo penial distinguem $P$. erinaceus de $P$. orientalis (Bekl.) e P. hyrcanus Bekl. (l. c.).

As cinco espécies de Promonotus aqui mencionadas ocorrem em águas de mares ou lagos, cuja salinidade é inferior à do oceano aberto. As descrições das três espécies de procedência puramente marinha (Steinböck 1932, p. 329) não foram publicadas, de maneira que ignoramos, se pertencem, realmente, a Promonotus.

\section{Subfamília Monocelidinæ Midelburg (1908, p. 104)}

Os achados de duas Monocelididæ com vagina, que não se enquadram na chave publicada no ano passado, obrigam a emendar esta :

1 Faringe na metade posterior do corpo, longe da extremidade anterior do intestino. $\ldots \ldots \ldots \ldots \ldots \ldots \ldots$

- Faringe no terço anterior do corpo, na extremidade anterior do intestino . . . .... Coleophora Steinböck (1932, p. 328). Steinböck \& Reisinger (1930, p. 22) confirmaram a posição da faringe, como 
foi descrita na diagnose original do tipo (hirudo Levinsen 1879). Não obstante, incluiu Steinböck (1. c.) Monocelis alba Lev., com faringe no último terço do corpo, em Coleophora, tornando, destarte, o gênero incompreensível. Na discussão do gênero Peraclistus Steinb. motiva-se a aplicação do nome do autor para êste e Coleophora.

2 Orifício vaginal ventral

- Orifício vaginal dorsal. .. Togarma Marcus $(1949$, p. 43$)$

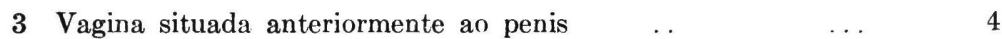

- Vagina situada posteriormente ao penis $\quad \ldots .96$

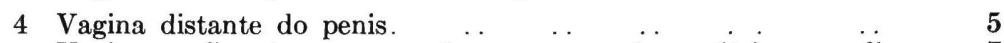

- Vagina confinante com o penis ou começando no átrio masculino. 7

5 Epiderme de núcleos intra-epiteliais. _. $\quad$ Meidiama Marcus (1946, p. 115)

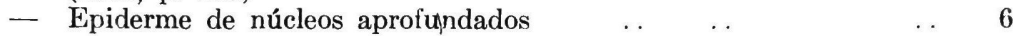

6 Com órgão músculo-glandular situado anterior (insularis Meixner 1928 a, p. 605) ou posteriormente (evelinæ Marcus 1946, p. 120) ao penis. . . Minona Marcus (1946, p. 120)

- Sem órgão músculo-glandular .. Monocelis Ehrenberg (1831; Graff 1913, p. 423)

7 Vagina externa, i. é, com poro no integumento $\quad$. $\quad$ Mesoda Marcus (1949, p. 49)

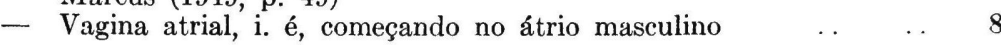

8 Vagina em comunicação direta com a bursa pré-penial ... Archiloa Beauchamp (1910, p. 211) com 2 espécies, uma com a bồca no meio do corpo (rivularis Beauch.); a outra, com a mesma no início do último terço do corpo (spinosa Jensen 1878, p. 69 ; Maristo 1938 emend.)

- Vagina em comunicação direta só com a bursa post-penial Archilopsis Meixner (1938, p. 6, 58)

9 Sem órgão músculo-glandular ; faringe muito comprida Necia, gen. nov.

- Com órgão músculo-glandular, perto do orifício feminino ; faringe de comprimento médio . . . . Peraclistus Steinböck (1932, p. 329)

\section{Genus : Monocelis Ehrenberg (1831 ; Graff 1913, p. 423)} Monocelis tabira, spec. nov. (Figs. 91-95)

$\mathrm{O}$ comprimento dos vermes viventes é de 1,5-2,4 $\mathrm{mm}$.; os fixados não ultrapassam $1 \mathrm{~mm}$. ; a largura é de 0,12-0,2 mm. A grossura máxima encontra-se no meio do corpo, que daí se atenua sucessivamente para diante. A extremidade caudal é espatulada. O corpo é incolor, sem manchas pigmentárias. Há dois olhos, de cálices acastanhados escuros ou pretos. A faringe (Fig. 92,f) encontra-se atrás do meio do corpo, frequentemente no início do último terço. Os órgãos copulatórios situam-se no espaço entre a extremidade posterior da faringe e o bordo caudal do corpo. O intestino (Fig.94,i) começa ao nível do cérebro (c) e termina atrás do poro feminino (Fig. 91,q).

Os cílios são curtos, um pouco maiores na cabeça, e ausentes na margem da placa caudal (Fig. 95). Aí são substituidos por papilas adesivas (h), de secreção vermelha, e dirigidas para diante. Esta direção das papilas e a sua forma apincelada lembram as de exemplares jovens de Minona evelinæx (Marcus 1946, p. 1'20 t. 23 f. 137 A). As células epidérmicas não conteem rabditos ; os seus núcleos são aprofundados em todo o corpo. Limites inter-celulares não se vêem. Glândulas de secreção cianófila ocorrem na cabeça (Fig. 94,g), e são numerosas também nas outras regiões do corpo. A mem- 
brana basilar e os músculos cutâneos anelares são finos ; os longitudinais, nítidos e no ventre mais fortes que no dorso.

A cápsula do cérebro (c) é indistinta. No bordo cerebral anterior situam-se, entre as células ganglionares, o estatocisto e, nos dois lados dêste, os olhos. O estatocisto contém dois núcleos de células litógenas. Cada ôlho compõe-se de um cálice unicelular, hemisférico e uma célula visual globosa. Esta salienta-se do cálice, é homogênea e cristalinóide.

A faringe (Fig. 91,f) de 0,13-0,14 mm. de comprimento dilata-se para trás. Os seus epitélios externo e interno são ciliados e de núcleos aprofundados. Os cílios internos acabam a certa distância (z) do início do esôfago (k). Os músculos longitudinais da faringe confinam com os epitélios ; os anelares, com o parênquima. Os citosomas das glândulas de secreção eritrófila e cianófila (d) situam-se extra-faringealmente e desembocam, todos, na orla da faringe, não no lume. $\mathrm{O}$ anel nervoso (n) encontra-se no quarto ectal do corpo faríngeo. A posição da bôca (b) varia entre o meio e o terço externo. O quarto ental da faringe separa-se do resto por uma dobra anelar e tem carater de esôfago (k). Aí faltam os cílios, e os núcleos das células altas são intra-epiteliais. O lume do intestino (i) pode obliterar-se em vermes no auge da digestão. O alimento observado nos animais presentes, colecionados com isca, consistia em sangue de peixe. Nos lados dorsal e ventral da parede intestinal dispõem-se as células claviformes de Minot (Fig. 91,m) em séries irregulares.

Os testículos (Fig. 93,t) são fracamente desenvolvidos em todo o nosso material que abrange ca. de 50 exemplares. Ocorrem 2-8 pequenos folículos ventro-medianos, que formam 1-2 séries entre o cérebro e a raiz da faringe. Os dutos eferentes são incognoscíveis. O órgão copulador masculino (Fig. 91) situa-se aproximadamente no meio entre o bordo posterior da faringe e a extremidade caudal do corpo e dispõe-se verticalmente à face ventral. O órgão é pequeno, de comprimento de $0,03 \mathrm{~mm}$., de largura de 0,02 mm., e piriforme. Começa internamente com a vesícula seminal (s), cuja parede é tão larga quão o lume. A parede compõe-se, de fora para dentro, de músculos longitudinais, fibras anelares, e epitélio. Vesícula granulorum separada inexiste; as glândulas grânulo-secretoras desembocam na parte ectal da vesícula seminal. $O$ duto ejaculatório, a continuação externa do lume da vesícula, corre dentro do penis, um pequeno cône pontudo, sem estilete, que penetra no diminuto átrio masculino.

Pouco anteriormente à faringe (f) situam-se os ovários (Fig. 93,o), providos de túnica celular. Alguns ovócitos ainda nos ovários encontramos já iseminados. Os vitelários (v) estendem-se da região post-cerebral até ao nível do poro feminino (q). Os ovovitelodutos reunem-se atrás da faringe (Fig. 95). Aí passa o ovoviteloduto comum (u) pela vagina e continua para trás, correndo lateralmente ao órgão copulador masculino. Bursa posterior não existe. O último trecho do duto comum post-bursal torna-se canal genital feminino, pois é circundado pelas glândulas argamassadoras (a) ; desemboca com o poro feminino (q), um pouco atrás do masculino (p).

Equidistantemente dêste, mas para diante, abre-se a vagina (Fig. 91,e) com curto tubo ciliado. Do ponto em que a vagina se encontra com o ovoviteloduto comum $(\mathrm{u})$, penetra a bursa $(\mathrm{r})$, representada por algumas células vacuolizadas, no tecido da parede intestinal ventral. A exiguidade desta 
bursa anterior (seminal, copulatória) parece ser carater específico, não consequência de determinado estado da maturidade sexual, pois é menos desenvolvida ainda em vermes com vitelários incipientes do que nos descritos, plenamente maduros. Em um indivíduo da nossa coleção existem dois poros vaginais, um maior e outro menor, situados simetricamente de cada lado da linha mediana ventral. As duas vaginas reunem-se antes da sua entrada no duto comum.

A duplicação descrita das vias copulatórias femininas lembra Monocelis balanocephala (Böhmig 1902, p. 29), Pseudomonocelis ophiocephala (Schmidt) Meixner (1943, p. 462) e as duas espécies de Kata, K. evelinæ Marcus (1949, p. 55) e $K$. leroda (Fig. 111-115), a primeira com vias copulatórias femininas completamente separadas, a segunda com reunião parcial das mesmas, da bursa para fora.

Ocorrência : Baía de Santos; ilha de São Sebastião, na areia fina da práia, perto de Ilhabela, imediatamente ao sul da Ponta Sta. Tereza; Rio de Janeiro, baía da Guanabara.

\section{Discussão de Monocelis tabira}

As espécies do gênero Monocelis podem ser divididas em três grupos: 1) órgão copulador masculino um penis inerme ; 2) órgão copulador masculino um penis armado ; 3) órgão copulador um cirro dentro de uma bolsa (cirrifera Mx., scalopura Marc.). Apenas as espécies do $10^{\circ}$ grupo precisam ser comparadas com .1 tabira. São estas : 1) lineata (Müll.), o tipo do gênero. Tem mancha ocular transversal e 500-600 folículos testiculares. 2) longiceps (Ant. Dug.) com rabditos e numerosos testículos, estendidos da raiz da faringe até à região pré-cerebral (Graff 1904-08, t. 24 f. 8). 3) balanocephala (Böhm.) sem olhos, com penis tubuloso e dois poros vaginais. 4) fuhrmanni Midelb. com distância muito grande entre o orifício vaginal e o poro masculino. 5) fasciata Graff, até $6 \mathrm{~mm}$., ao comprido, e com 2 olhos estrelares circundados por mancha pigmentada transversalmente estendida sôbre o dorso. 6) gamblei Graff, sem olhos, com rabditos, e os testículos, em parte, situados ao lado da faringe. A espécie foi re-encontrada por Southern (1936, p. 65), mas não pormenorizadamente descrita. 7) Menos certa ainda é viridirostris (Sabuss.), também sem olhos e com cauda fina, frequentemente torcida em espiral.

\section{Genus : Mesoda Marcus (1949, p. 49)}

\section{Mesoda gabriella Marc. (Fig. 96)}

Mesoda gabriellæ Marrus 1949 , p. 50 t. 11 f. 65-69

A espécie foi encontrada, pela primeira vez, num dia de sol, de março de 1948, na areia da práia da Ilha de S. Sebastião, acumulada debaixo da nadadeira de um cação. O lugar do achado original pertencia à região da enchente regular; a areia era bastante sêca, e a salinidade deve ter sido alta, devido à exposição ao sol durante várias horas. Em junho de 1949, colhemos material na água salobra e uma dúzia de exemplares maduros na areia da água doce formada por um riacho quasi sem correnteza, habitado por girinos e pequenas Cyprinodontidæ (guarús). A água não tinha comunicação com o mar, mas enchentes altas levadas por ventos fortes podem atingi-la. $\mathrm{Na}$ época da colheita do material, a salinidade eventualmente 
existente na água achava-se aquém da perceptibilidade pela língua humana $(0,175 \%)$; tinha o paladar de água doce, e a qualidade olfativa ligeiramente pantanosa. Mesmo lembrando a maior conservação da salinidade dentro da areia do que na água acima desta (Milne 1940, p. 114, 136, 137), Mesoda gabriellæ merece ser chamada de muito eurihalina.

Em outros espécimes, obtidos na areia da água de salinidade normal, observámos uma extensão da bursa ressorvente (Fig. 96, r) ainda não registrada. O órgão estende-se em direção ventral até ao tubo músculo-dermático, e o fundo desta bursa encontra-se, com isso, circundado pelas glândulas argamassadoras $(\mathrm{g})$.

\section{Genus : Necia gen. nov.}

Monocelididæ com vagina (Monocelidinæ) que corre caudalmente ao órgão copulador masculino, abrindo-se juntamente com êste. Sem bursa seminal (anterior) e sem bursa posterior. O órgão masculino é um bulbo minúsculo com duto ejaculatório. Núcleos epidérmicos aprofundados em todo o corpo. Faringe muito comprida; alongamentos intestinais sólidos, cefálico e caudal, faltam.

Tipo do gênero: Necia sopha, spec. nov.

$\mathrm{Na}$ descrição de $M e s o d a$, discutimos, há pouco, o grupo dos gêneros das Monocelidinæ, cujas espécies possuem os poros vaginal e masculino vizinhos ou reunidos (Marcus 1949, p. 49). Com êste grupo convem comparar Necia. $\mathrm{O}$ orifício comum da vagina e do órgão masculino, aproxima Necia mais a Archilopsis e Achiloa que a Mesoda, onde os dois poros são separados. Archilopsis distancia-se de Necia pela ausência de comunicação entre vagina (duto vaginal ou vagina secundária da terminologia de Meixner) e ovoviteloduto (duto comum).

Resta portanto, para o confronto especial, o gênero Archiloa Beauchamp (1910, p. 211). Como foi dito (Marcus 1949, p. 37), deve-se eliminar dêste gênero A. wilsoni Stirewalt, Kepner \& Ferguson (1940) que pertence às Promonotinæ. Não possue vagina, e a chamada "bursa seminal" (l. c., p. 129) é um órgão músculo-glandular anexo ao átrio masculino, sem ligação com as vias femininas (f. 1, 3, 7, b). Das duas espécies de Archiloa, $A$. rivularis Beauch. e $A$. spinosa (Jens.), distingue-se Necia pelos caracteres da diagnose que se referem à posição da vagina, ao órgão copulador masculino à bursa anterior e à faringe.

A vagina de Necia sopha, situada caudalmente ao penis, constitue, sem dúvida, um sinal disjuntivo importante do novo gênero. Outra espécie, Peraclistus itaipus (Fig. 104), com órgão músculo-glandular armado, perto do orifício feminino, levou-nos à comparação com Monocelis oofaga Friedmann (1924). A anatomia desta não foi, evidentemente, entendida na descrição original, como será exposto na discussão de Peraclistus. A nosso vêr, Peraclistus possue a mesma posição da vagina em relação ao penis, como Necia, mas distingue-se desta pelo órgão músculo-glandular, o penis evaginável, e a faringe de comprimento médio.

\section{Necia sopha, spec. nov. (Figs. 97-102)}

$\mathrm{O}$ comprimento dos vermes, medido dos exemplares conservados e aclarados em óleo de cravo, é de 0,7-1, $3 \mathrm{~mm}$. ; a largura, de 0,1 mm. São apro- 
ximadamente cilíndricos, possuindo região pré-cerebral comprida e atenuada e cauda espatulada (Fig. 97). São brancos, sem olhos. A faringe (f) pertence à metade posterior do corpo ; a bôca (b) situa-se na extremidade caudal da faringe, abrindo-se o poro masculino e vaginal imediatamente atrás desta. $\mathrm{O}$ orifício feminino (q) distancia-se mais do poro masculino (p) que da extremidade posterior.

O corpo é revestido por cílios de comprimento medíocre. Os núcleos (Fig. 102, j) da epiderme (k) são aprofundados no corpo inteiro. Raramente reconhecem-se os limites entre as células epidérmicas que não conteem rabditos. Escassas glândulas de secreção eritrófila ocorrem na cabeça. As glândulas do corpo, de secreção cianófila, começam ao nível da raiz da faringe e tornam-se mais densas em direção caudal. $\mathrm{Na}$ própria cauda são cerradas. Aí encontram-se numerosas glândulas (z), cujos citosomas se situam internamente à musculatura cutânea. A sua secreção basófila é baciliforme. Entre estas glândulas existem outras, de secreção acidófila (y). Ocupam principalmente os bordos da espátula caudal, mas algumas vêem-se também nas faces dorsal e ventral da cauda. Os pinceis de secreção destas glândulas, vermelhas nos cortes corados com hematoxilina-eosina, formam papilas adesivas que correspondem às descritas no trabalho de Midelburg (1908, p. 83-84 t. 6 f. 2, 6). A membrana basilar é mediocremente desenvolvida. Os músculos cutâneos anelares são finos ; os longitudinais (1), mais grossos.

O cérebro (Fig. 100, c) é circundado por cápsula nítida. O estatocisto é pré-cerebral, extra-capsular e contíguo a células ganglionares cerebrais. Os nervos látero-ventrais (n) reunem-se na cauda (Fig. 98) e suprem células sensoriais piriformes, que se tingiram nos cortes.

A direção principal da faringe (Fig. 101, f) coincide com a do corpo. $\mathrm{O}$ epitélio da bolsa faríngea é baixo. A faringe é muito comprida $(0,25 \mathrm{~mm}$.) e dilata-se para fora. $O$ epitélio faríngeo externo tem núcleos aprofundados nos três quartos ectais da sua extensão e cílios nos dois terços ectais. O último quarto ental do epitélio externo mostra núcleos em posição normal. $\mathrm{O}$ epitélio interno tem núcleos aprofundados na sua metade ectal e cílios no primeiro quarto ectal (d). Epitélio alto, de núcleos normais, caracteriza a metade ental da faringe como esôfago (e). Nas partes faríngeas revestidas por epitélio de núcleos normais, existe musculatura inconspícua ; nas outras partes, apõem-se as fibras longitudinais aos epitélios ; as anelares, ao parênquima. As últimas são mais fortes no lado interno. O parênquima contém numerosos núcleos e também os dutos das glândulas faríngeas, de secreção eritrófila e cianófila, cujos citosomas (h) são extrafaríngeos. As desembocaduras das glândulas encontram-se na orla da faringe, onde os cílios faltam. $\mathrm{O}$ anel nervoso (a) situa-se no oitavo ectal da faringe.

$\mathrm{O}$ intestino (i) estende-se do cérebro (c) até à extremidade caudal. $\mathrm{O}$ seu lume oblitera-se no auge da digestão. As células claviformes de Minot (m) são raras e irregularmente distribuidas.

Os testículos (t) apresentam-se como folículos ventrais, irregulares. Geralmente, há 2-6 folículos, mas em um verme foi encontrado um único testículo. A túnica própria testicular é nítida. Os dutos eferentes são muito finos. O órgão copulador masculino é pequeno (comprimento $0,04 \mathrm{~mm}$.) e dista pouco da faringe. O órgão compõe-se de uma vesícula musculosa (Fig. 99, s) e um duto ejaculatório curto. A vesícula contém entalmente esper- 
matozóides ; ectalmente, secreção granulosa (r). O duto é revestido por cutícula tênue e indistintamente separado do minúsculo átrio masculino. Pela parede dorsal dêste entra a vagina $(\mathrm{u})$, e de trás desemboca no átrio um tufo de glândulas (x). O poro masculino (p) e o orifício bucal (b) são providos de esfíncteres (es).

Os ovários (o) situados pouco antes da faringe (f) são envolvidos pela sua túnica. Os vitelários (v) começam a certa distância do cérebro (c) e atingem posteriormente quasi o poro feminino (q). Os ovovitelodutos reunem-se (wi) caudalmente à faringe. O epitélio baixo dêles continua na vagina (u), que ocupa um plano transversal situado atrás do órgão copulador masculino. A vagina é circundada por alto cilindro de músculos anelares, separados das fibras da vesícula comum (s). Apenas um anel baixo, ectal, envolve em comum a vagina e o átrio masculino. Caudalmente à entrada da vagina torna-se o epitélio da via feminina mais alto, de maneira que se recomenda denominar o trecho caudal de canal genital feminino (w). Nem nêste, nem no trecho pré-vaginal, no duto comum, encontrámos qualquer estrutura que possa ser comparada a uma bursa. Espermatozóides foram vistos nos ovovitelodutos da região pré-faríngea. Torna-se, destarte, indispensável admitir a subida imediata dos espermatozóides ejaculados na vagina, para os ovários, sem armazenamento em bursa seminal. O canal genital feminino continua para trás e abre-se com o poro feminino (Fig. 98, q), no meio de grandes tufos de compridas glândulas argamassadoras (g).

Ocorrência: Os vermes vivem entre algas da zona da ressaca, abaixo da linha da vasante média. Ca. de vinte exemplares foram obtidos, successivamente, na baía de Santos (ilha das Palmas e costão do Forte Itaipú ; X. de 1947, VII. 49) e na ilha de São Sebastião (IX. 48, IV., VI. e XI. 49).

\section{Peraclistus Steinböck (1932, p. 329)}

Monocelididæ com vagina (Monocelidinæ) que desemboca caudalmente ao órgão masculino, juntamente com êste ou a pequena distância do mesmo. Penis um tubo evaginável, inerme. Anteriormente ao orifício feminino, um órgão músculo-glandular com estilete encurvado, cuticular. Sem bursa seminal (?) e sem alongamento intestinal sólido, cefálico ou caudal. Núcleos epidérmicos aprofundados. Faringe de comprimento médio.

Tipo do gênero: Peraclistus oofagus (Friedmann 1924, p. 81).

Monocelis oofaga foi descrita sem verificação dos dutos eferentes. Friedmann tomou, por isso, o órgão provido de estilete por órgão copulador masculino. A ausência de espermatozóides e de secreção granulosa no suposto órgão copulador considerou (p. 89) condicionadas pelo estado reprodutivo do material. Chamou "flagellum" o duto ejaculatório e, citando uma das figuras de Beauchamp (1920, f. IV), comparou-o com o flagelo que ocorre nos Tricladida Paludicola (Bresslau 1933, p. 135). Friedmann estranhou, é verdade, a presença de um órgão conhecido no penis dos Tricladida, no aparêlho feminino de uma Monocelis. Até aqui, não temos dúvidas a respeito da nova interpretação de Peraclistus oofagus (Friedm.).

Chamamos "vagina antralis" o órgão que Friedmann designou como "bursa copulatrix" O ajuntamento de vagina e penis, em $P$ oofagus, aproxima êste a Necia sopha. O órgão músculo-glandular, os caracteres do penis e da faringe recomendam, porém, separar $P$ oofagus de Necia e reuni-lo 
com a espécie a ser descrita em seguida. Os "saquinhos accessórios" da "bursa" de $P$. oofagus não podem ser interpretados. A posição dêles não corresponde à de vesículas accessórias de uma bursa seminal, talvez ligadas ao intestino. Tais vesículas situam-se dorsalmente ao ovoviteloduto. $\mathrm{O}$ calibre dos saquinhos é bem maior que o de dutos eferentes, como tais desembocam na vesícula seminal de Peraclistus itaipus (Fig. 105, d). Todavia, as ilustrações de Friedmann não são tão boas que se prestem ao entendimento imediato. Assim parece difícil imaginar que um verme de corpo filiforme se apresente na forma da figura 1, mesmo admitindo contração intensa na fixação e compressão forte no intermédio aclarador. $O$ tipo do gênero continua, destarte, não completamente inteligível.

Steinböck (l. c.) e Bresslau (1933, p. 227, 279) apõem aos gêneros Coleophora e Peraclistus "Fügenschuh 1933" como nome de autor e ano da descrição. Mas, o trabalho de Fügenschuh nunca foi publicado, de maneira que o nome de Steinböck e o ano de 1932 devem ser combinados com os dois gêneros. Ambos são precários; Coleophora, pelas razões expostas na chave das Monocelidinæ (veja p. 53) ; Peraclistus, devido à analise, a meu ver errada, do tipo. A cada um dos dois gêneros acrescentou Steinböck (l. c.) ainda dois "nomina nuda", cuja descrição por Fügenschuh não saiu.

Ectocotyla paguri Hyman (1944, p. 2) já foi aproximada a Monocelis oofaga (Westblad 1948, p. 18-19). A posição da faringe de Ectocotyla combina com a de Monocelis hirudo Lev., o tipo do gênero Coleophora.

\section{Peraclistus itaipus, spec. nov. (Figs. 103-105)}

O hábito geral dos vermes assemelha-se ao de Minona evelinæ Marcus (1946, p. 120), mas êles alcançam maturidade com comprimento muito menor. Também Necia sopha apresenta traços em comum com a espécie presente, cuja faringe, de tamanho médio, constitue o primeiro sinal disjuntivo. O comprimento dos vermes viventes atinge $1,5 \mathrm{~mm}$.; a largura, $0,2 \mathrm{~mm}$. As medidas correspondentes de animais fixados são $1,1 \mathrm{~mm}$. e $0,15 \mathrm{~mm}$. Da extremidade anterior dos exemplares viventes distam : o estatocisto 0,2 $\mathrm{mm}$. ; o bordo posterior do cérebro (c) $0,27 \mathrm{~mm}$. ; a raiz da faringe 0,94 $\mathrm{mm}$.; a orla desta $1,18 \mathrm{~mm}$. A largura máxima encontra-se ao nível da faringe (f) ; a cauda é espatulada (Fig. 103). Os vermes são incolores e destituidos de olhos.

O comprimento dos cílios acusa o duplo da altura da camada cobertora da epiderme, cujos núcleos se encontram em baixo da musculatura cutânea. Rabditos não ocorrem. Glândulas cianófilas formam uma corôa volumosa na cabeça, havendo outras, relativamente numerosas, na extremidade caudal. No corpo restante, são escassas (k). Algumas glândulas eritrófilas notam-se na região anterior. As papilas adesivas (h) da parte post-faríngea do corpo são menos desenvolvidas que em Necia. Corresponde isto ao habitat mais protegido de Peraclistus itaipus, entre os tubos sólidos de Terebellidæ e dentro dos mesmos, emquanto Necia sopha vive entre algas do litoral superior, batidas pelas ondas. A musculatura cutânea, anelar (rm) e longitudinal (l) é mediocremente desenvolvida.

A cápsula cerebral é fraca. Evidentemente inclue o estatocisto, aposto ao neuropilema e circundado pelas células ganglionares da calota cerebral 
anterior. Os nervos ventro-laterais (Fig. 105, n) são grossos, como o é a comissura caudal dos mesmos (Fig. 104).

A bôca (b) coincide com o bordo posterior da faringe (f). A bolsa faríngea (e) é revestida por epitélio nucleado. Este é substituido pelo faríngeo, na região da raiz da faringe. Aí passa a parede externa do corpo faríngeo à bolsa. $\mathrm{O}$ comprimento da faringe corresponde, aproximadamente, à metade da longura faríngea de $N$ sopha. Vermes viventes de $P$. itaipus mostram a faringe quasi sempre dobrada em ângulo reto (Fig. 103, f), dispondo-se a raiz paralela, o cálice perpendicularmente à direção longitudinal do corpo. A faringe é de 0,12-0,15 mm., ao comprido, nos vermes conservados. $O$ seu epitélio interno é ciliado e de núcleos aprofundados, na parte ectal, caliciforme; sem cílios e de núcleos normais, na ental, tubular. Os músculos acompanham apenas o trecho ciliado. O epitélio faríngeo externo é aprofundado em toda a sua extensão e provido de músculos ; os cílios, porém, não atingem a raiz, nem ocorrem na parte adjacente, topograficamente pertencente à bolsa. Os músculos longitudinais são interna e externamente sub-epiteliais ; os anelares, apostos ao parênquima, sendo as duas camadas igualmente tênues. As glândulas (j) desembocam todas na orla, da qual o anel nervoso (Fig. 104, n) dista apenas $0,028 \mathrm{~mm}$. Dorsalmente à faringe corre o tubo que estabelece a comunicação entre o intestino pré-faríngeo (i) e o post-faríngeo. O intestino total estende-se do bordo anterior do cérebro (c) até às glândulas argamassadoras (g). As células intestinais apresentam-se individualizadas, como se vê no corte transversal (Fig. 105, i) ; as clavas de Minot (m) são raras.

Os testículos (Fig. 103, t) são pequenos e situados entre o cérebro e os ovários (o). Os folículos são circundados por túnica própria nítida, em oposição às indicações de Friedmann $(1924$, p. 89$)$ a respeito de $P$ oofagus. Os testículos são pouco numerosos ; todavia ocorrem, excepcionalmente, até 3 folículos em um corte transversal. Várias fases da espermatogênese vêem-se no mesmo folículo. O duto eferente não foi visto na parte prê-faríngea, onde deve ser impar, mediano. Bifurca-se para passar nos dois lados da faringe, entre os citosomas aprofundados das glândulas faríngeas (j). Atrás da faringe aparecem os dois dutos eferentes (d) ventralmente aos nervos principais (Fig. $105, \mathrm{n})$. Entram separadamente na calota anterior da vesícula seminal (s) que contém espermatozóides. A vesícula é um órgão esférico, de diâmetro de 0,04-0,045 mm., revestido por epitélio nucleado e circundado por grosso manto de músculos. Para dentro da vesícula invagina-se o penis (Fig. 104, p), um tubinho estreito, inerme, cuja raiz é concrescida com o integumento ao redor do poro masculino (q).

Os vitelários (Fig. 103, x) são laterais ; começam ao nível do cérebro e estendem-se até ao do orifício vaginal externo (r), aproximadamente. Os ovários (Fig. 104, o), pré-faríngeos, são volumosos. Vê-se, nêles, um feixe de espermatozóides apôsto ao ovócito mais crescido. Os ovovitelodutos (u) correm dorsalmente aos nervos principais (n) e reunem-se imediatamente atrás do nível da vesícula seminal (s). Aí entra a vagina estreita (v) no ovoviteloduto, sem formar uma dilatação que possa ser chamada bursa seminal. O orifício vaginal externo (r) encontra-se caudalmente ao poro masculino (q), muito perto dêste. $O$ ovoviteloduto comum continua para trás, onde a sua parede grossa forma um espessamento especial (w), encravado na parede intestinal. Havendo espermatozóides nêste apêndice, tra- 
ta-se nêle, evidentemente, de um órgão fagocitário de espermatozóides excedentes, uma bursa ressorvente. Os espermatozóides são daí, possivelmente, transmitidos para o intestino. Glândulas argamassadoras eritrófilas (g) desembocam, em parte, no último trecho do duto feminino comum, em parte, ao redor do poro feminino (z), situado a pequena distância da extremidade caudal.

Anteriormente a êste poro, mas com orifício externo próprio (y), abre-se o órgão músculo-glandular. E esférico e tem diâmetro de 17-20 micra, dos quais 4 micra, de cada lado, cabem à parede musculosa. Contém secreção granulosa, fracamente eritrófila. Um estilete cuticular, ventralmente encurvado, de 12 micra, ao comprido, e de 6 micra de largura, na base, projeta-se na reentrância do integumento, que estabelece a comunicação entre o órgão e a face ventral. O órgão parece-se com o de Minona evelinæ Marc. e de Peraclistus oofagus Friedm.; o de Minona insularis Meix. tem estilete reto e situa-se anteriormente ao penis. Os órgãos correspondentes das Promonotinæ "Archiloa" wilsoni Stirew., Kepn. \& Ferg. ("rather a nidamental gland than a bursa seminalis") e Digenobothrium inerme Pal. não teem estilete.

Ocorrência : Perto de Santos, não costão do Forte Itaipú, 6 exemplares entre tubos de Terebellidæ, na linha da vasante maxima; 24. VIII. 1949.

\section{Família : Otoplanidæ Hallez (1892, p. 108) \\ Genus : Philosyrtis Giard (1904, p. 1065)}

Otoplanidæ cuja faringe é curta, tem forma de colar e se dirige ventralmente. $\mathrm{O}$ intestino é indiviso. A extremidade anterior demarca-se por um sulco transversal, ventral, nem sempre distinto. Os núcleos epidérmicos são aprofundados, na região da sola rasteira ; intra-epiteliais, no corpo restante. As papilas adesivas são digitiformes. O órgão copulador masculino contém 6 pares de cerdas.

O gênero Philosyritis foi, originalmente, incluido, com reserva, nos Gastrotricha aberrantes. No início, Remane (1926, p. 631) era ainda da mesma opinião, mas chegou, no decorrer das suas pesquisas, a definir a verdadeira posição de Philosyrtis nas Otoplanidæ (l. c., p. 690). A localização da faringe, o estatocisto, e a ausência de bôca e anus terminais da espécie presente não nos deixaram em dúvida quanto à sistematização geral da mesma.

A definição genérica, porém, devemos à tabela póstuma de Meixner, mencionada na introdução do trabalho atual. Nesta tabela, encontra-se a descrição sumária de uma espécie, certamente congenérica com a presente. Silenciamos o nome e a procedência da espécie de Meixner, pois ela ainda não foi publicada. Pela mesma razão, não pormenorizamos a diferença entre a espécie de Meixner e a nossa, a qual reside nas cerdas peniais. Da organização do tipo do gênero, $P h$. monotoides Giard, conhece-se somente o suficiente, para incluir a espécie de Meixner e a atual, com reserva, no mesmo gênero. Parece, porém, fácil re-examinar $P h$. monotoides que vive na costa de Ambleteuse (Pas-de-Calais, França), na areia fina, pouco movimentada, coberta por manchas acastanhadas de Diatomáceas e Peridíneas (Meixner 1938, p. 128). 


\section{Philosyrtis eumeca, spec. nov. (Figs. 106-110)}

Vermes adultos atingem ca. de $0,8 \mathrm{~mm}$. de comprimento e 0,06-0,1 $\mathrm{mm}$. de largura. $\mathrm{O}$ volume do corpo de $P$ h. eumeca corresponde, assim, à milésima parte do de Parotoplana moya Marc. O corpo tem forma de faixa, mas é atenuado nas duas extremidades, achatado no ventre e convexo no dorso. A região anterior, hemisférica, é separada da parte seguinte por um sulco transversal ventral, mais ou menos pronunciado. De cada lado do corpo, ocorrem ca. de 8 papilas adesivas (k), havendo, além disso, 4-8 caudais, diversamente agrupadas. Cada papila representa uma célula alongada, com núcleo basilar, intra-epitelial (Fig. 109, k) ; as terminações apinceladas adesivas das papilas laterais dirigem-se para diante, como nos indivíduos jovens de Minona evelinæ (Marcus 1946, f. 136 A) ; as das caudais, para trás, lembrando, no seu aspecto individualmente variável, as papilas de Meidiama lutheri (ibid., f. 123). A cada papila pertence uma glândula aprofundada, que fornece a secreção pegajosa.

Os vermes são enormemente móveis, delizam "correndo sôbre os cílios", pulam dentro da água, como Stylonychia, aderem aos grãos de areia, contraem-se e enrolam-se. São incolores e transparentes; os vitelários (v) destacam-se como fitas brancas, opacas, à luz refletida. A diferença do aspecto dos vermes adultos (Fig. 106) e jovens (Fig. 107) provém da posição da faringe (f). Esta dista pouco $(0,05 \mathrm{~mm}$.) da extremidade caudal dos indivíduos jovens e aproxima-se invulgarmente à terminação anterior (distância : $0,275 \mathrm{~mm}$.), nos adultos.

O botão cefálico é provido de estereocílios (Fig. 106, sc) compridos, frequentemente curvados. Alguns longos cílios encontram-se ainda nas regiões laterais e caudal. Os cílios da sola rasteira são de 6 micra, ao comprido; a própria sola $(\mathrm{x})$ é larga $(0,05 \mathrm{~mm}$.) até à bôca (b). Daí para trás, os cílios ventrais ocupam um sulco mais estreito, que termina no gonóporo (go), à distância de $0,1 \mathrm{~mm}$. da extremidade caudal. $\mathrm{O}$ sulco que separa a região anterior é ciliado. Dêle estendem-se dois curtos campos ciliados (w) lateral e um pouco dorsalmente, sem atingir a região dorso-mediana.

A epiderme é muito fina (ca. de 1 micron); os núcleos são normais, com excepção do sulco cefálico, dos campos ciliados laterais e da sola rasteira, onde são aprofundados. Rabditos (r) eritrófilos, de 6-7 micra, ao comprido, ocorrem nos dois terços anteriores do corpo e são especialmente cerrados no botão cefálico. Os corpúsculos refrativos de $\mathrm{Ph}$. monotoides Giard (1904, f. 2 ; descrição : p. 1065) são, provavelmente, rabditos cefálicos. No terço anterior, até à faringe, foram vistas glândulas rabditógenas (q) aprofundadas. As fibras anelares da musculatura cutânea são finas ; as longitudinais, um pouco mais grossas, mas, em consideração à agilidade dos vermes, os músculos parecem relativamente fracos.

$\mathrm{O}$ cérebro (c) é volumoso e atinge $0,11 \mathrm{~mm}$. de comprimento, inclusive dois lóbulos anteriores (l) que flanqueiam o estatocisto (e). Sendo acumulações de células ganglionares, os lóbulos lembram as massas granulosas ("äussere Körnerhaufen”) dos Polycladida. Em Otoplanidia endocystis Meixner (1938, p. 9 f. 7 F, F 1) ocorre posição semelhante do estatocisto, sendo apenas os lóbulos anteriores da espécie aludida, não retos, mas encurvados para o plano mediano. Na espécie presente existem, além de núcleos da cápsula do estatocisto ainda dois grupos de células formadoras do estatolito, 
cada grupo com 5 núcleos (Fig. 108). Giard (l. c.) acentuou a ausência das "pierres accessoires" em $P h$. monotoides. Células ópticas não ocorrem na espécie aquí em mãos.

A faringe (Fig. 106, f) é curta, ectalmente estreita, entalmente larga e circundada por bolsa (Fig. 109, j) profunda. O epitélio interno é provido de cílios compridos e de núcleos aprofundados ; o externo, sem cílios, tem núcleos normais. O anel nervoso (n) faríngeo é ental. Os lumes da faringe e do intestino (i) são separados por um diafragma (h). As células intestinais são baixas, havendo algumas clavas de Minot (m) no assoalho do intestino, na proximidade da faringe. A parede do intestino é muito tênue, nos lugares em que se sobrepõe às gônadas e ao órgão copulador. Bolsas do intestino (d) penetram no espaço entre as gônadas femininas (o, v) e o integumento, como em Parotoplana moya (Marcus 1949, p. 61).

Os dois testículos (Fig. 106, t), dos quais um pode faltar, emitem dutos eferentes, cada um com várias dilatações $(\mathrm{y})$, vesículas seminais accessórias, na região post-faríngea. Mais para trás ainda, os dutos entram na vesícula seminal principal (s), vindos de trás. A região anterior, ectal, da vesícula é revestida por células grânulo-armazenadoras (sg).

O duto ejaculatório é provido de doze cerdas (Fig. 110) que se apõem ao lado interno da parede membranosa do duto, reforçando-a. Estas cerdas pertencem a três tipos; o conjunto delas forma um semicírculo ventral e lateral. $\mathrm{O} 1 .^{\circ}$ tipo abrange um par de cerdas maiores (34 micra) e três pares de menores, quanto às hastes. As bifurcações de todas estas cerdas terminam com uma ponta distal e outra, proximal, encurvada para trás. As cerdas maiores são as mais caudais-externas ; as menores formam uma série arqueada que se estende ventralmente às cerdas externas. Ao $2 .^{\circ}$ tipo pertence um par de cerdas (21 micra) reunidas dorsalmente ao duto ejaculatório, no meio. As pontas distais das bifurcações destas cerdas entrelaçam-se. O $3 .^{\circ}$ tipo é representado por um par de cerdas anteriores $(26$ micra). Terminam sem bifurcação, com ponta simples, ligeiramente encurvada em forma de S. Estas cerdas salientam-se rostralmente, além das restantes. $\mathrm{O}$ aparêlho inteiro projeta-se para dentro do átrio (a).

Os ovários conteem poucos ovócitos (o), em parte, já inseminados (Fig. 109), emquanto se encontram ainda na sua posição original, posteriormente aos testículos (t), anteriormente à faringe (f). Caudal e lateralmente aos ovários, estendem-se os vitelários (v), metidos na parede do intestino (i), cujos divertículos (d), entre o integumento e as gônadas, já foram mencionados. Os ovovitelodutos reunem-se ventralmente ao penis (Fig. 106, p), no ponto (z) em que desembocam no átrio (a). Cada ovoviteloduto recebe a secreção de algumas glândulas argamassadoras (g), no seu trecho mais ectal. Outras glândulas do mesmo tipo abrem-se ao redor do gonóporo (go).

Ocorrência : Baía de Santos, ilha Porchat, na areia fina (diâmetro dos grãos : ca. de 0,2 mm.), misturada com fragmentos de conchas, abaixo da linha da vasante regular (XI. 1948 ; IX., X. 1949). Além da rica população de Philosyrtis eumeca houve, na mesma areia, ainda Acoela em forma de faixa, evidentemente novos, Monocelididæ (Meidiama lutheri), Nematoplanidæ (Nematoplana naia), Kalyptorhynchia, um Nemertino e vários Copépodos. Nos fragmentos das conchas encontrou-se Phoronis ovalis Str. Wright (du Bois-Reymond Marcus 1949). 


\section{Nota sôbre o crescimento de Philosyrtis eumeca}

$\mathrm{O}$ material era rico em indivíduos jovens ; os menores dêstes com 0,2 $\mathrm{mm}$., ao comprido. Notou-se, novamente, quão pouco crescem o cérebro e a faringe, na vida post-embrionária. $O$ cérebro de um verme jovem de 0,2 $\mathrm{mm}$., de longura total, acusou comprimento de $0,1 \mathrm{~mm}$., sendo o dos vermes adultos de $0,11 \mathrm{~mm}$. Outro indivíduo jovem, cujo corpo foi de $0,25 \mathrm{~mm}$., teve faringe de $0,05 \mathrm{~mm}$., ao comprido. A mesma medida ocorre nos vermes adultos, cuja faringe é apenas mais larga que a dos jovens. $O$ crescimento atinge, principalmente, a região post-faríngea, cuja longura, de $0,05 \mathrm{~mm}$. nos jovens, aumenta para $0,5 \mathrm{~mm}$., nos adultos. Esta parte do corpo abriga os vitelários volumosos e, caudalmente a êstes, ainda o aparêlho copulador masculino, de comprimento de $0,07 \mathrm{~mm}$.

\section{Genus : Kata Marcus (1949, p. 55)}

\section{Kata leroda, spec. nov. (Figs. 112-115)}

Os vermes brancos foram colecionados juntamente com outras (Otoplanidæ, Kata evelinæ e Parotoplana moya (veja Marcus 1949, p. 55, 59), das quais pouco se distinguem no seu hábito geral. Anatômica e histologicamente são bem diferentes. Kata leroda é de $2 \mathrm{~mm}$., ao comprido, no estado vivente ; $K$. evelinæ, até $8 \mathrm{~mm}$. Os vermes da espécie atual tiveram, quando fixados, comprimento de $1 \mathrm{~mm}$., e largura de 0,18-0,22 $\mathrm{mm}$.. A região anterior com o lóbulo cefálico, os 2 pares de tufos ciliados (Fig. 113, y, z), inseridos em fossetas que podem ser protraidas, formando então papilas, e os dois campos de cílios, que circundam as papilas, correspondem aos mesmos órgãos em $K$. evelinæ. Também o cérebro (c) envolvido pela cápsula, com 2 olhos sem pigmento no quadrante dorso-caudal, e o estatocisto (e) situado anteriormente ao cérebro são semelhantes em ambas as espécies.

A posição da faringe (Fig. 112, f), a extensão do complexo dos órgãos copulatórios, e a configuração da metade posterior do corpo, diferem em $K$. leroda e $K$. evelinæ. A faringe da última insere-se no limite entre o $20^{\circ}$ e o último terço do corpo ; a de leroda, no entre o $3 .^{\circ}$ e o $4 .^{\circ}$ quinto, portanto mais para diante. Não obstante é a região caudal, i. é, a entre o orifício da vagina (va) e a extremidade posterior em leroda muito curta $(0,05$ $\mathrm{mm}$.). Corresponde a um vigésimo da longura total em leroda ; a um sexto desta, em evelinæ. O complexo dos órgãos copulatórios é relativamente mais comprido na nova espécie.

A faringe (f) cilíndrica, cuja direção funcionalmente principal se dispõe paralelamente à face ventral, e a bôca (b), no início do último quarto da faringe, repetem caracteres de evelinæ. A extensão da sola ciliada (u) difere nas duas espécies : em evelinæ não ultrapassa a raiz da faringe ; em leroda atinge $o$ gonóporo $(\mathrm{g})$.

A largura da sola ciliada é de $0,07 \mathrm{~mm}$. (em evelinæ: $0,12 \mathrm{~mm}$.) ; o comprimento dos cílios desta, de 0,011 mm. (evelinæ: 0,012 mm.). As glândulas adesivas (k) são muito mais raras que em evelinæ; mesmo na ponta caudal é mistér procurá-las. Os rabditos (r), que faltam na região da sola ciliada (como em evelinæ), são menos numerosos e menores (6 micra, contra 10-20 em evelinæ). Algumas glândulas adesivas ocorrem também no lóbulo 
cefálico, mas as glândulas cefálicas cianófilas de evelinæ não existem em leroda.

Todos os núcleos epidérmicos são aprofundados, como em evelinæ. Repetem-se também os botões fungiformes de secreção cianófila, que devido à sua pequenez não foram desenhados nas nossas figuras, e as células rabditógenas (Fig. 114, q) no parênquima. A musculatura cutânea é mais fraca que em evelinæ, nomeadamente a dorsal. Comparando um verme adulto de $K$. leroda, de largura de $0,2 \mathrm{~mm}$., com um jovem de $K$. evelin $x$, de largura de 0,182 , verificamos a grossura da musculatura dorsal, de 5 micra em leroda, de 11 micra em evelinæ; a da ventral, de 11-14 micra em leroda, de 16-20 micra em evelinæ. Na nova espécie não vimos fibras transversalmente estriadas. Os citosomas com os núcleos (u) das células da sola ciliada (Fig. 114) situam-se, na espécie presente, internamente à musculatura longitudinal, como os elementos correspondentes da epiderme restante. Em evelinæ, encontram-se os núcleos das células da sola entre uma camada externa e outra, interna, dos músculos longitudinais. Os feixes dêstes condicionam, em ambas as espécies, a disposição dos rabditos em séries longitudinais.

$\mathrm{O}$ cérebro (Fig. 113, c) é esférico, de diâmetro de 0,04-0,05 mm.. Reconhecem-se nervos sensoriais anteriores e 3 pares de nervos posteriores longitudinais, os ventrais (n), que são os mais grossos, os laterais (Fig. 114, $\mathrm{nl}$ ) e os dorsais (nd). O estatocisto é volumoso (diâmetro : 0,022-0,028 mm.) e mostra, como o de $K$. evelinx, 2 grupos de 4 células estatolitógenas cada um.

Do aparêlho digestivo mencionamos apenas as diferenças entre $K$. leroda e $K$. evelinæ. São estas : o anel nervoso externo da faringe é mais tênue na espécie atual ; não há, nesta, glândulas cianófilas que desemboquem no lume da faringe ; as clavas de Minot (mi) são espalhadas entre o epitélio intestinal, não concentradas na entrada do intestino; os limites entre as células intestinais são nítidos ; o intestino post-faríngeo é representado por um trecho curto, quasi sem lume, situado dorsalmente ao complexo copulador.

Os testículos foliculares (t) começam atrás do cérebro (c), a pequena distância dêste. Atingem, aproximadamente, a raiz da faringe. Há, de cada lado, vários folículos cerradamente juxtapostos, que alternam com os lóbulos dos vitelários (v). O duto eferente de $K$. evelinæx, que permite a passagem dos espermatozóides aos vacúolos intra-epiteliais do intestino, re-encontra-se em $K$. leroda. Também a bifurcação do duto eferente e a entrada dos 2 dutos, assim originados, na região anterior da vesícula seminal (Fig. 115A, s) é a mesma. As caudas dos espermatozóides parecem grudadas pelas glândulas (vg) no fundo caudal da vesícula. O duto ejaculatório (d) atravessa um bulbo, cujas células parietais armazenam secreção granulosa. Em $K$. evelinæ corresponde ao bulbo uma papila penial cônica, sem secreção granulosa. A bainha penial (p) circunda o aparêlho cuticular (Fig. 115B) que proemina no átrio (a). O aparêlho compõe-se de 22 acúleos (Fig. 115C) que são biscúspides e dispostos ao redor de um estilete central, em forma de funil. O comprimento do último é de $0,02 \mathrm{~mm}$. ; a sua largura ental, de 0,011 $\mathrm{mm}$.

Os ovários (Fig. 112, o), ao nível da raiz da faringe, indicam a terminação caudal da extensão dos testículos (t). Os ovovitelodutos (l) circundam 
o bulbo masculino, reunem-se e formam o ovoviteloduto comum (lc). O trecho externo dêste recebe âs glândulas argamassadoras (h), pouco antes da sua desembocadura no átrio. Cada ovoviteloduto emite, como em $K$. evelinæx, um canal ou ramo ventral (lp), que corre de cada lado do gonóporo (g), para trás. Em $K$. evelinæ, permanecem os dois canais separados, e os órgãos caudalmente seguintes são também pares. Em $K$. leroda, existem apenas canais caudais pares (lp) ; a bursa é impar (w), e a vagina (va), igualmente impar, abre-se com um único poro dorsal (vp).

Ocorrência: Ilha de São Sebastião, na areia fina, juntamente com Kata evelinæ e Parotoplana moya. Ca. de 12 exemplares foram iscados com vísceras de galinha em abril de 1949.

\section{Discussão de Kata leroda}

Os sinais disjuntivos entre a nova espécie e $K$. evelinæx, o tipo do gênero, já foram incluidos na diagnose precedente. Basta, por isso, repetir aqui apenas os mais salientes. São êstes, da morfologia externa, o tamanho muito menor do corpo ; a curteza da região caudal e a extensão maior da sola ciliada. No integumento observam-se : escassez de papilas adesivas ; ausencia de glândulas cefálicas cianófilas ; musculatura cutânea mais fraca, nomeadamente no dorso, e posição dos núcleos da sola ciliada internamente à musculatura longitudinal, não entre uma camada externa e outra, interna, desta. O aparêlho digestivo mostra clavas de Minot irregularmente distribuidas, não concentradas na entrada intestinal e somente um curto trecho post-faríngeo do intestino, aí quasi sem lume e situado dorsalmente ao complexo copulatório. Entre os órgãos masculinos destacam-se a papila penial que é um bulbo curto, não um cône, e as células parietais dêste bulbo que conteem secreção granulosa. Nos órgãos femininos é notável a entrada dos 2 canais caudais dos ovovitelodutos na bursa impar, sendo igualmente impar a vagina que se abre com um único poro dorsal.

\section{Família : Nematoplanidæ Meixner (1938, p. 6) \\ Genus : Nematoplana Meixner $(1938$, p. 9)}

\section{Nematoplana asita, spec. nov. (Figs. 116-127)}

O comprimento dos vermes viventes é de 4-7 mm., a grossura de 0,1 mm.. As medidas do material conservado são $2,2-3,4 \mathrm{~mm}$. e 0,12-0,15 $\mathrm{mm}$., respectivamente. A extremidade anterior é arredondada (Fig. 122). Atrás do cérebro (c) o corpo dilata-se e aumenta paulatinamente de largura, até que atinge o seu máximo atrás da faringe (Fig. 121, f). Daí para trás estreita-se rapidamente, sendo a extremidade caudal cuspidata. Toda a parte anterior e média do corpo é cilíndrica ; a post-faríngea, achatada, foliácea. A côr é branca, afora o conteudo intestinal, de colorido variável. Os cálices ópticos são pretos (Fig. 116). Os cílios são uniformemente desenvolvidos, em toda a parte do corpo, com excepção de uma corôa de cílios maiores (Fig. 122, ci), provavelmente sensoriais, ao redor da cabeça. De cada lado da cauda dispõem-se 8-15 grupos de células glândulares adèsivas (Fig. 126, h), basófilas nos cortes corados com hematoxilina-eosina. Con-, cordam com as glândulas correspondentes de Togarma evelinæ Marcus (1949 p. 44), Nemato plana naia e Tabaota curiosa. 
A faringe de um verme crescido, ainda imaturo, de comprimento do corpo de 2,5 mm., em bálsamo, é de $0,28 \mathrm{~mm}$., ao comprido, i. é, $11,2 \%$ do comprimento total do animal ; a de um exemplar jovem $(0,75 \mathrm{~mm}$.), $0,12 \mathrm{~mm}$. (16\%). No verme de $2,5 \mathrm{~mm}$., a raiz da faringe dista $1,87 \mathrm{~mm}$. da extremidade anterior ; a bôca faríngea, $2,15 \mathrm{~mm}$., sendo a cauda de 0,35 $\mathrm{mm}$. ( $14 \%$ da longura total). Durante a maturação das gônadas femininas degenera a faringe, sendo em um verme maduro, de $3,4 \mathrm{~mm}$. de comprimento, maximamente de $0,12 \mathrm{~mm}$. $(3,5 \%)$ ou, sem as dobras que surgem na faringe regressiva, de $0,06 \mathrm{~mm}$.. A região caudal cresce à custa da faringe, acusando, no verme maduro de $3,4 \mathrm{~mm}$., $0,7 \mathrm{~mm}$. ou $20,6 \%$ do comprimento total.

$\mathrm{O}$ integumento (Fig. 122) é formado por células (altura 6 micra, diâmetro 4-7), de superfície poligonal e de limites distintos. São revestidas por cílios que são compridos (6 micra), nos vermes imaturos, i. é, normalmente alimentados. Os núcleos epidérmicos, de 3 micra de diâmetro, são intraepiteliais. Os rabditos (3 micra), vermelhos nos cortes corados com hematoxilina-eosina, formam séries longitudinais na superfície e deixam livres os limites inter-celulares. Pequenas células substituidoras, de côr azul e isentas de rabditos, são frequentes no epitélio. Lacunas inter-celulares deixam passar a secreção de glândulas eritrófilas (g). A membrana basilar é conspícua. A grossura da musculatura cutânea é de 6 micra, mas esta medida possue apenas valor aproximativo, porque os vermes se contraem no momento da conservação.

Glândulas cefálicas (gc), de secreção granulosa e vermelha, desembocam ao redor da extremidade anterior. Possuem reservatórios dilatados dos seus dutos, situados em baixo da musculatura cutânea. Os citosomas aprofundados penetram, nomeadamente nos dois lados, entre as células do intestino (Fig. 122). Na sua maioria, abrem-se em um círculo circum-cefálico, reconhecível, no verme vivente, pela corôa de cílios (ci) acima mencionada. Algumas das glândulas cefálicas desembocam um pouco atrás dêste círculo. A côr da secreção é muito mais brilhante que a das glândulas cutâneas restantes.

$\mathrm{O}$ cérebro (c) tem de comprimento $0,055 \mathrm{~mm}$. e de largura $0,042 \mathrm{~mm}$. e dista $0,11 \mathrm{~mm}$. da extremidade anterior. A cápsula que é nítida inclue os olhos situados ântero-dorsalmente. A posição e a estrutura dos olhos correspondem ao que se conhece de $N$. coelogynoporoides $\mathrm{Mx}$. e $N$. naia Marc. Há dois cálices muito aproximados um do outro, ou mesmo contíguos (Fig. 116), de 20 micra de extensão ântero-posterior e 18 micra de largura, cada um com uma célula óptica, cuja parte refrativa, cristalinóide, se ressalta fora do cálice. Dos nervos reconhecem-se apenas os dois)ventrolaterais (Fig. 120, n), envolvidos por membrana semelhante à cápsula cerebral. Dêstes nervos saem seguidamente muitos outros menores, para cima e para baixo.

O parênquima é parcamente desenvolvido. Atrás do cérebro (c), parênquima histologicamente peculiar (Fig. 122, pa) preenche a região ao redor das glândulas cefálicas (gc) deixada livre pelo intestino. Esta região vê-se também nas figuras de $N$. coelogynoporoides Meixner (1938, f. 6 D, 44). As pequenas células bem delimitadas, de citoplasma pouco tingível, assemelham-se às do intestino cefálico (ic) e são, talvez, elementos sustentadores. 
A musculatura dorso-ventral reconhece-se nas partes pré-faríngea e postfaríngea do corpo. Orgãos excretórios não foram vistos.

A bôca (Fig. 123, b) situa-se anteriormente ao meio da faringe (f). Esta é oblíqua e tem forma de um tonel alongado. A bolsa faríngea (k), formada por células baixas, circunda a faringe ("pharynx plicatus") até à raiz. $\mathrm{O}$ lume faríngeo estende-se de ântero-dorsal a póstero-ventral, como na espécie seguinte. A forma singular do órgão, aliás muito variável, conforme a contração, torna a parede anterior dêle mais comprida que a posterior. A parede faríngea externa, ciliada, alonga-se para a área da bolsa, especialmente no lado posterior, onde o alongamento se nota mesmo na faringe meio evaginada. Ć́lios ocorrem nos epitélios interno e externo; os núcleos do primeiro são normais; os do segundo, aprofundados. A musculatura acompanha a extensão da parede faríngea para a bolsa e compõe-se de fibras longitudinais, sub-epiteliais e de anelares, apostos ao parênquima. Os últimos são grossos, especialmente os internos. As glândulas (j) dispõem-se em ('́ŕrculos, havendo 3 tipos, as de secreção azul, as vermelhas, e as côr de rosa pálida. Desembocam na orla faríngea ; algumas das azuis, também na face externa. $\mathrm{O}$ anel nervoso (Fig. 123, n) situa-se na metade anterior da faringe. A bôca faríngea interna é estreitada por um diafragma (di), uma dobra anelar, de epitélio baixo. $\mathrm{O}$ orifício da dobra que estabelece a comunicação entre os lumes faríngeo e intestinal situa-se ventralmente ao centro do anel.

No verme plenamente maduro, a faringe apresenta-se reduzida (Fig. 125,127, f) a uma simples dobra cônica. O componente protoplasmático diminue, não o nuclear. Os cílios desaparecem; os núcleos dos epitélios interno e externo são intra-epiteliais ; vestígios da musculatura manteem-se ; as glândulas e o parênquima involuiram.

As células do intestino (i) são sempre individualizadas e projetam-se, muitas vezes, claviformemente para o lume. A altura delas varia nos vários estádios digestivos; em células repletas de bolinhas ressorvidas notam-se ainda dispersos concrementos grumosos, amarelados-acastanhados. As clavas de Minot (m) não são concentradas e, às vezes distinguíveis das glândulas cutâneas ( $\mathrm{g}$ ) encravadas entre as células do trato alimentar, apenas pela secreção mais nitidamente granulosa e a posição mais para dentro. Em vermes contraidos formam-se bolsas intestinais que aproximadamente correspondem aos grupos das glândulas cutâneas. Normalmente os contornos do intestino são lisos. O epitélio intestinal dispõe-se racemosamente ao redor das dobras aludidas. Dorsalmente ao cérebro e à faringe estreita-se o intestino, exibindo, nêstes pontos, membrana própria distinta. Conteudo intestinal passa pelo tubo posterior (Fig. 123, l) para o intestino caudal, como em Togarma e Tabaota. Anteriormente termina o intestino digestivo no cérebro, a cuja face dorsal se sobrepõe um tubo estreito, constituido pela membrana própria com poucas células. Este tubo dilata-se na região précerebral, onde forma o intestino cefálico sólido (ic). As células volumosas e vesiculosas dêste possivelmente solidificam a parte anterior, especialmente solicitada, quando o verme atravessa a areia. Os esfíncteres descritos da base do intestino cefálico de $N$. coelogynoporoides Meixner (1938, p. 46 f. 44, sph) não conseguimos verificar na espécie presente.

Os testículos (Fig. 117, 124, t) começam um pouco atrás do cérebro e formam 2 séries longitudinais, cada uma de vários folículos. Ao se desenvolverem os vitelários (v), que são mais dorsais, comprimem os testículos 
de tal modo que êstes formam uma série ventro-mediana (Fig. 119, t). Emquanto os ovários (o) são jovens (Fig. 117), são ultrapassados, para trás, pelos testículos, que, nesta fase, atingem a bolsa (k) da faringe. Com o progresso do desenvolvimento dos ovários, desaparecem os testículos posteriores, distando então os últimos dêles $0,7 \mathrm{~mm}$. da raiz da faringe. Vários estádios da espermatogênese podem ocorrer no mesmo folículo ; em vermes no auge da fase masculina conteem todos os folículos somente espermatozóides. A túnica testicular é indistinta. Os folículos podem, nos estádios médio e adiantado, penetrar na parede intestinal, aproveitando, com isso, os produtos nutritivos (Fig. 117). Para fora adelgaçam-se os folículos e comunicam-se com os dutos eferentes (Fig. 119, 125, d), que são para-medianos. Desembocam em 2 vesículas seminais (Fig. 124, 125, s), principais (verdadeiras), encurvadas em forma de $\mathrm{S}$. Os núcleos da musculatura destas vesículas são espalhados. Caudalmente a estas situa-se a vesícula seminal accessória (q), sem músculos parietais, um reservatório impar, avolumado por massas de espermatozóides dispostos sem ordem. Dois dutos seminais conduzem os gonócitos das vesículas pares ao reservatório da secreção granulosa (Fig. 127, r), cuja musculatura é tênue. No reservatório insere-se o estilete penial cuticular (p), que é transparente (Fig. 118). Começa com funil largo e continua com ferrão gancheado, cuja parede ventral dilatada lembra o esporão de Togarma e Tabaota. O estilete projeta-se para o lume do átrio, por sua vez, aposto à parede caudal da bolsa faríngea.

A distância entre o cérebro e os vitelários (v) é menor $(0,2 \mathrm{~mm}$.) que a entre êste e os testículos (t). Os vitelários são dorso-laterais e, nos vermes maduros, como que cortados (Fig. 124), à distância de $0,7 \mathrm{~mm}$. da faringe. Aí começam os ovários (o), situados no meio de células (w) que consideramos como modificações dos vitelários. Estas são ligeiramente granulosas e neutrófilas. Na fase feminina jovem (Fig. 117) existem testículos (t) ao lado dos ca. de 10 pares de ovários na região aludida. Dêstes ovários destacam-se apenas ovócitos em crescimento (o). As túnicas ováricas (u) reconhecem-se como envoltórios nucleados na fase feminina madura (Fig. 119), rara no nosso material. Cada ovario contém, nesta fase, apenas um ovócito crescido (o), cujo citoplasma passa por transformações (wi), talvez vitelógenas, emanantes do núcleo e espalhadas para a periferia, como nas Plagiostomidæ (Böhmig 1890, p. 320-328). Na região dos ovários dos vermes maduros desenvolvem-se feixes grossos de músculos transversais (Fig. 120, z). Uma série dêstes é dorsal e apõe-se internamente aos músculos cutâneos longitudinais, a outra situa-se, aproximadamente, ao nível dos dutos eferentes (d). Provavelmente atuam os músculos transversais na ovipostura, empurrando os ovos para fora dos sacos ováricos. Dêstes vimos 6-8, de cada lado, no verme maduro (Fig. 124, 125) e, além disso, sacos vazios constituidos pela túnica ovárica, cujos ovos, evidentemente, já foram postos. Os sacos ováricos comunicam-se com os ovovitelodutos (e) que correm ventralmente e se reunem atrás da faringe, ventralmente ao reservatório da secreção granulosa. O ovoviteloduto comum recebe a secreção das glândulas argamassadoras (a) que o circundam por todos os lados. O poro feminino $(\mathrm{y})$ dista $0,12 \mathrm{~mm}$. do masculino (x). 


\section{Ocorrência de Nematoplana asita e observaçũes biológicas}

Iscando com peixe morto, vísceras de galinha e cadáver de rato, obtivemos a espécie na práia da ilha de São Sebastião na areia grossa, média e fina. Nomeadamente a areia mediocremente fina, habitada por Protodrilus cordero $i$ du Bois-Reymond Marcus (1948, p. 5) e composta de grãos de 0,2-2 $\mathrm{mm}$. de diâmetro mostrou-se riquíssima em indivíduos, em setembro de 1948. Milhares dêstes foram concentrados pela isca, a cabeça de um bagre marinho, colocada perto da linha da enchente regular, a poucos cms. abaixo da superfície da areia. Com as iscas, conseguimos, das fases reprodutivas, apenas a masculina jovem, não a masculina adulta e nada das femininas. Colecionámos no verão (janeiro), no outono (março, abril), no inverno (junho, julho, agosto) e no início da primavera (setembro), obtendo vermes imaturos e alguns estádios masculinos iniciais em todos os mêses. Por conseguinte, a época reprodutiva de Nematoplana asita independe da estação do ano. Vermes no começo do desenvolvimento dos órgãos generativos masculinos trazidos para o laboratório e aí mantidos durante três semanas (23. VII. -11. VIII. 49) revelaram a razão da ausência de vermes maduros na isca. A faringe degenera sucessivamente durante o desenvolvimento progressivo dos órgãos reprodutivos, e os vermes não comem mais. Conhecemos êste fenômenos das Naididæ em entre os Turbelários, de Catenula lemnæ (Marcus 1945, p. 49-50), cuja degeneração somática progride do trato alimentar ao cérebro e ao estatocisto. A degeneração da faringe ocorre também, como verificamos agora, durante o amadurecimento de Nematoplana naia Marcus (1949, p. 63) e em Tabaota curiosa (Fig. 129, 134), também das Nematoplanidæ.

Como alimento de Nematoplana asita encontrámos no seu intestino: suco tissular de vários animais, células branquiais e sangue de peixe, Enchytræidæ, Polychæta e pedicelários de ouriços do mar arrastados à praia.

A espécie mostra fototaxia negativa pronunciada e desliza na bacia inclinada, para baixo (Marcus 1949, p. 48, 66), do mesmo modo como Togarma evelinæ Marc., das Monocelididæ, e Nematoplana naia. A reação dêstes Proseriata sem estatocisto dificilmente poderia ser provocada pela gravitação (geotaxia). Parece consequência da correnteza surgida no declive da areia. Sendo rara a reotaxia negativa no reino animal, o fenômeno merece talvez estudo especial.

\section{Discussão de Nematoplana asita}

O comprimento da nova espécie (até $7 \mathrm{~mm}$.) é intermediário entre o de $N$. coelogynoporoides Meixner $(1938$, p. 9) que ultrapassa $12 \mathrm{~mm}$. e $N$. naia Marcus (1949, p. 63) que atinge apenas $3 \mathrm{~mm}$.. Da morfologia de coelogynoporoides conhece-se pouco ; distingue-se de asita pela epiderme sincial com núcleos filiformes, por dois esfíncteres na base do intestino cefálico e 3-4 ovários, de cada lado. Em naia são os núcleos dos epitélios faríngeos externo e interno aprofundados ; todas as glândulas faríngeas desembocam na bôca faríngea externa; os dutos eferentes abrem-se na vesícula seminal accessória ; a vesícula seminal principal é ímpar ; a parte que topograficamente corresponde ao reservatório da secreção granulosa é um tubo encurvado, e o estilete é formado por dois ganchos. De $N$. naia não se conhecem, até agora, mais que 2 ovários, de cada lado. 


\section{Tabaota, gen. nov.}

Nematoplanidæ sem olhos cerebrais, mas com dois órgãos refrativos post-cerebrais, semelhantes aos de Stenostomum. O intestino caudal estreita-se para trás e termina com uma vesícula dorsal, de parede tênue, aposta ao integumento também adelgaçado, estabelecendo-se, destarte, um poro anal transitório.

Tipo do gênero: Tabaota curiosa, spec. nov.

A descoberta de um representante das Nematoplanidae, sem olhos do tipo comum de ocelo invertido, obriga à restrição do gênero Nematoplana às espécies oculadas. A ocorrência de corpúsculos refrativos ("schüsselförmige Organe"), comparáveis somente às células visuais com faosoma (Marcus 1945, p. 25-26), é muito singular entre os Proseriata. O poro anal, se bem que apenas temporariamente pérvio, é o primeiro caso de um tal órgão entre os Turbelários que não sejam Polycladida.

\section{Tabaota curiosa, spec. nov. (Figs. 128-141)}

O comprimento dos vermes é de $2-18 \mathrm{~mm}$.; a grossura, de 0,1 $\mathrm{mm}$. e menos, em vermes jejuados ; até $0,2 \mathrm{~mm}$., em recem-alimentados. Com excepção do colorido do conteudo intestinal, os animais são incolores. O corpo é cilíndrico até além da faringe (f) e achatado apenas na parte caudal, que é espatulada. Esta região é guarnecida por ca. de 12 grupos de glândulas adesivas (Fig. 134, h), de cada lado. A região anterior (Fig. 128) tem forma de clava alongada. Ao nível do cérebro (ce) ocorre ligeira constrição. Caudalmente a esta dilata-se o corpo sucessiva e inconsideràvelmente, até ao poro feminino $(q)$. O trecho caudal diminue em largura. A faringe ressalta-se no verme vivente (Fig. 129, f) como um cone, cujo ápice se dirige para fora. O órgão é muito mais comprido (Fig. 137) que largo (Fig. 138); do comprimento de 0,3-0,45 mm., no verme crescido, ainda imaturo, reduz-se a $0,025 \mathrm{~mm}$., no animal maduro (Fig. 133). A região post-faríngea, de 0,3-0,4 $\mathrm{mm}$., ao comprido, em vermes estéreis, cresce a 1-1,2 mm., nos férteis.

Vermes viventes mostram, na cabeça (Fig. 130) : 1) uma corôa de cílios, evidentemente sensoriais ; 2) o intestino cefálico (l) opaco, branco à luz refletida, preto, à transmitida ; 3) o cérebro (ce) oblongo ; 4) os dois órgãos refrativos (c), de aparecimento e visibilidade irregulares ; 5) ca. de 12 órgãos terminais (r) do aparêlho excretor, excepcionalmente reconhecíveis.

A epiderme (d) de vermes conservados em estádio estendido é baixa ( 2 micra de altura) e provida de cílios de 4 micra, ao comprido. As células da cabeça são mais altas ( 5 micra) e os cílios um pouco maiores (5 micra). $\mathrm{O}$ diâmetro das células epidérmicas, cuja superfície é poligonal, é de 8-12 micra. Conteem curtos rabditos eosinófilos (2 micra), dispostos em séries longitudinais e ausentes nos limites inter-celulares. Os núcleos epidérmicos são, geralmente, chatos ; às vezes, lobulados (Fig. 136, d). A grossura da membrana basilar varia. A área terminal da cabeça é delimitada por um sulco fino, em que grupos de cílios, grudados entre si, são implantados. Não ocorrem glândulas cefálicas especiais ; as cutâneas (e), aprofundadas e eritrófilas, penetram com os seus citosomas na região entre a musculatura cutânea e o intestino (Fig. 140) ou mesmo entre as células intestinais. A secreção das glândulas adesivas caudais (h) é cianófila. Além dos 12 grupos, de 
cada lado, já mencionados, há mais um sub-terminal (Fig. 139, h). Cada grupo (Fig 136) abrange numerosas células, cujos tratos de secreção passam pelas 10-15 células epidérmicas sobrepostas, crivando-as e circundando os núcleos.

A musculatura cutânea anelar é muito fraca na região anterior, torna-se mais grossa para o meio do corpo e é forte ao redor da bôca. As fibras longitudinais são muito grossas e dispostas em feixes (Fig. 132), mais espessas no ventre que no dorso. Anteriormente ao cérebro, desaparece a musculatura longitudinal ; caudalmente à faringe, torna-se fraca. Músculos dorsoventrais e transversais são raros ; os núcleos do parênquima notam-se, principalmente, nos sulcos entre os feixes das fibras longitudinais.

O cérebro (Fig. 130, ce) é mais comprido que largo e alto, e circundado por cápsula nítida. Membrana semelhante a esta acompanha os nervos látero-ventrais principais (Fig. 135, n), não somente nas raizes, como em certos Holocoela (Karling 1940, p. 149), mas em toda a sua extensão. Verificámos, agora, esta membrana ao redor dos troncos nervosos principais também em Togarma evelinæ e nas duas espécies de Nematoplana que temos em mãos. Não a consideramos como surgida no lugar de células, em consequência de fixação insuficiente (Böhmig 1906, p. 429 : Bdelloura), mas como envoltório realmente não-celular, uma continuação da cápsula cerebral. Parece-nos comparável ao neurilema dos Nemertinos (veja, p. e., Corrêa 1948 , p. 4). Dois gânglios ântero-laterais, extra-capsulares, correspondem às massas granulosas externas ("äussere Körnerhaufen") dos Polycladida. Os órgãos refrativos (Fig. 130, c) situam-se no parênquima da região post-cerebral, perto dos troncos látero-ventrais. Cada órgão é formado por uma célula vesiculosa, cujo aspecto piriforme se deve à fibra nervosa. O órgão cortado (Fig. 135) lembra, com a disposição anelar do seu protoplasma, o núcleo algo saliente e a massa refrativa central, o anel de sinete que o órgão refrativo de Stenostomum amphotum apresenta no corte (Marcus 1945, p. 23).

A bôca (Fig. 137, b), o orifício da bolsa faríngea (z), situa-se no meio da faringe (f). Esta pertence ao tipo do "pharynx plicatus", mas é de forma muito peculiar. Apenas o lume corresponde ao de uma faringe tubulosa, o corpo é dorso-medianamente côncavo e abriga aí o canal (y) que estabelece a comunicação entre os lumes intestinais pré-faríngeo e post-faríngeo. A bôca faríngea externa é estreita ; a interna, mais restrita ainda, é coarctada pela dobra cônica do diafragma (x) aí projetado para o lume faríngeo. A bolsa faríngea, cujo epitélio é invulgarmente rico em núcleos, abrange toda a faringe e ainda o canal de comunicação (Fig. 138, y) acima mencionado. Os epitélios faríngeos externo e interno são ciliados ; os núcleos do externo, aprofundados ; os do interno, normais. Além das fibras musculares longitudinais sub-epiteliais e as anelares, apostas ao parênquima, há ainda radiais, densamente dispostas. $\mathrm{O}$ anel nervoso (w) aproxima-se da orla faríngea. Nesta desemboca também a maioria das glândulas (g), cujos citosomas extrafaríngeos, situados para diante e para trás, distam muito $(0,8-1,2 \mathrm{~mm}$.) da faringe. Várias glândulas faríngeas abrem-se entre as células do epitélio faríngeo externo, dorsalmente à bôca.

$\mathrm{O}$ trecho do intestino $(\mathrm{j})$ situado anteriormente ao diafragma $(\mathrm{x})$ pode ser chamado esôfago, pois é delimitado por células não digestivas. Elementos semelhantes revestem o tubo de comunicação (y). Os limites das células intestinais (Fig. 131, i) são distintos, mesmo quando se alongam e incorporam partículas alimentares, nos casos observados, eritrócitos (pe) de pei- 
xes. O corpo de vermes que comeram, há muito pouco tem̄po, da isca, acusou diâmetro de $0,2 \mathrm{~mm}$., cabendo, dêste diâmetro, 0,176 mm. ao conteudo intestinal e $0,012 \mathrm{~mm}$., de cada lado, às paredes do corpo (7 micra) e do intestino (5 micra). Vermes no auge da resorpção não mostram mais a dilatação máxima do seu corpo e são mais contraidos. As medidas foram : diâmetro total $0,154 \mathrm{~mm}$., cabendo dêste $0,01 \mathrm{~mm}$., de cada lado, ao integumento inclusive a musculatura cutânea. O resto, $0,134 \mathrm{~mm}$., cabe ao intestino, cujo epitélio enormemente alto faz desaparecer o lume do órgão. As clavas de Minot (m) são dispersas, mas, de certo modo, acumuladas ao longo do meio da parede ventral do intestino. A membrana própria do mesmo é grossa. Destaca-se, como em Nematoplana asita, especialmente no canal de comunicação (y) e no fino tubo supra-cerebral, que liga o trato alimentar com o intestino cefálico (l). As células turgescentes dêste condicionam o aspecto claviforme da cabeça do verme vivente. A extremidade anterior torna-se, depois da fixação, frequentemente côncava, devido ao encolhimento do intestino cefálico.

$\mathrm{O}$ epitélio ressorvente do intestino post-faríngeo estende-se longamente para trás (Fig. 139). No último trecho, porém, é substituido por células menos altas, sem inclusões alimentares. O fundo do fino canal terminal dirige-se para o dorso. No verme vivente, nota-se aí uma vesícula retal, de parede atenuada. Grumos fecais, arredondados e pouco volumosos, foram vistos no canal e na vesícula. A epiderme sobreposta a esta apresenta-se, no verme vivente, como membrana fina. Como se vê pelos cortes mediano (Fig. 139) e horizontal (Fig. 140), esta membrana (v) é formada pela camada externa da epiderme com os seus cílios, os grânulos basilares dêstes e os rabditos. Núcleos epidérmicos, membrana basilar e musculatura cutânea faltam. A saliência, visível no animal vivente, transformou-se, no corte, em ligeira reentrância (v), em consequência da contração dos músculos integumentares vizinhos. Evacuação de fezes ainda não vimos ; não obstante, consideramos a estrutura descrita como anus temporariamente em função.

Os testículos (Fig. 132, 133, t) são ventro-laterais, podendo haver 500600 folículos de cada lado. Em um verme (comprimento : $10 \mathrm{~mm}$.), de fase masculina completamente madura e com ovários já bastante desenvolvidos, começam os testículos à distância de $2 \mathrm{~mm}$. da extremidade anterior e estendem-se sôbre $6 \mathrm{~mm}$. do comprimento total. Em um outro exemplar acabam mais para diante, distando os últimos folículos mais da extremidade posterior. Os testículos desaparecem, evidentemente, da região adjacente à raiz da faringe nas fases femininas adiantada e completa, como em Nematoplana asita. Os folículos formam uma série, de cada lado, situadas ventralmente aos troncos nervosos principais (Fig. 132, n). Os folículos de cada série conteem fases diferentes da espermatogênese, e o mesmo folículo pode abrigar células germinativas em estádios diversos. Em parte, os folículos podem penetrar entre as células intestinais, como em Nematoplana asita; nestas condições, os folículos apresentam-se como que pedunculados, pois a sua túnica alonga-se, formando dútulos eferentes. Estes são ligados aos dois dutos eferentes (de), de paredes finas, mas nucleadas. Vêem-se ainda atrás do poro feminino (Fig. 133, q), à distância de $0,4 \mathrm{~mm}$. da extremidade caudal, voltando, daí, novamente para diante. A disposição par dos dutos eferentes continua até ao bulbo (u), em que o estilete cuticular (s) se insere. Os trechos dos dutos entalmente ao bulbo são vesículas granulorum (Fig. 133, k), pois 
armazenam a secreção granulosa de glândulas circunjacentes. Vesículas seminais não foram observadas. Tabaota curiosa combina, estranhamente, a presença de dois reservatórios da secreção granulosa com ausência de vesículas seminais. O lume do bulbo ejaculatório (Fig. 141, u) é revestido por ćlios ; a parede, formada por células altas. O estilete (s), de 0,17 mm., ao comprido, lembra o de Togarma evelinæ, re-encontrando-se o esporão sustentador e até a célula formadora (eu) do estilete. O poro masculino (p) do verme maduro aproxima-se da parede posterior da bolsa faríngea (z) e dista $0,12 \mathrm{~mm}$. da bôca (b).

Os vitelários (Fig. 132, vi) situam-se dorsalmente aos troncos nervosos principais $(\mathrm{n})$. Terminam à distância de $1,2-0,75 \mathrm{~mm}$., aproximadamente, da bôca, i. é, na mesma região em que os testículos na fase de ovários adiantados acabam (Fig. 133). Em ambos os lados do corpo seguem 2 a 3 ou mais gonócitos femininos, os maiores de $0,04 \mathrm{~mm}$. de diâmetro, cujas duas séries ocupam $0,3-0,35 \mathrm{~mm}$. da região pré-faríngea. As túnicas nucleadas definem êstes ovócitos como ovários. As vias eferentes femininas não foram vistas ; desembocam com o poro feminino (q), equidistante da bôca (b) e da extremidade posterior. Aí dispõem-se dois grossos pacotes de glândulas (a), situados no meio da região post-faríngea. São de coloração neutrófila, mas, apesar disso, parecem corresponder às glândulas argamassadoras dos outros Proseriata.

\title{
Ocorrência de Tabaota cửiosa e observações biológicas
}

Os vermes foram iscados em vários mêses (IV, VI, VII, IX) dos anos 1948 e 49, na ilha de São Sebastião, na areia média formada por grãos de 1-2 mm. de diâmetro. Fases sexuais notámos apenas em junho ; tratou-se de estádios masculinos jovens. Vermes imaturos colhidos em junho amadureceram, no laboratório, no decorrer de 4 semanas. Como em Nematoplana naia e $N$ asita, degenera a faringe durante o desenvolvimento da fase feminina. A tigmotaxia positiva de Tabaota curiosa é pronunciada ; os vermes aderem aos grãos de areia por meio das suas glândulas caudais. $\mathrm{Na}$ bacia inclinada, os animais não descem. Reagem de uma maneira especial sôbre a agitação da água e areia no recipiente, saindo com dois terços do seu comprimento para fora da areia. Ao ter a água voltado a ficar calma, os vermes penetram logo, dentro de 20 segundos, aproximadamente, na areia. Animais mutilados na cabeça não se enterram.

\author{
Ordo : Polycladida Lang (1881, p. 188) \\ Subordo : Acotylea Lang (1884, p. 425, etc.) \\ Sectio : Craspedommata Bock $(1913$, p. 56 , etc.) \\ Família : Discocelidæe Laidlaw (1903b, p. 12)
}

Em oposição a Bock (1913, p. 61), consideramos Thalamoplana suficientemente separada de Discocelis para merecer distinção genérica. Adenoplana distingue-se, dos gêneros restantes da família, pela vesícula granulorum e pela ausência de um penis ou de um órgão que, pelo menos, possa ser chamado "papila penial" Mas, a comunicação larga da vesícula granulorum com o átrio masculino, como existe em Adenoplana, e a muscula- 
tura comum que envolve a vesícula e o átrio possibilitam considerar a vesícula como pertencente ao teto do átrio. Não se trata de uma "vesícula granulorum intercalar" (Stummer-Traunfels 1933, p. 3510), pois é antes "terminal" O duto ejaculatório de $A$. obovata (Schmarda) e as vesículas seminais de $A$. evelinæ entram, é verdade, na vesícula. Esta, porém, não emite um duto masculino comum ; o lume continua no atrial. Os gêneros da família podem ser reunidos da maneira seguinte :

1 As vias eferentes masculinas terminam com dilatação revestida por epitélio grânulo-secretor $\quad \ldots \quad$ Adenoplana Stummer- Traunfels $(1933$, p. 3510)

- As vias eferentes masculinas sem dilatação revestida por epitélio $\begin{array}{llllllll}\text { grânulo-secretor } & \ldots & \ldots & \ldots & \ldots & \ldots & \ldots & 2\end{array}$

2 Com vesícula de Lang $\quad \ldots \quad \ldots . . . .3 .3$ Sem vesícula de Lang. . . . Semonia Plehn (1896, p. 157)

3 Orifícios masculino e feminino separados .. Thalamoplana Laidlaw (1903b, p. 5 ; 1904, p. 132)

- Orifícios masculino e feminino reunidos .. ... . . . . .

4 Numerosas vesículas granulorum na parede do penis e na do átrio Discorelis Ehrenberg 1836; Lang (1884, p. 466)

- Vesículas granulorum, em número de 7-11, ao redor do átrio masculino .. Coronadena Hyman (1940, p. 450)

\section{Genus : Adenoplana Stummer-Traunfels (1933, p. 3510)}

\section{Adenoplana evelinæ spec. nov. (Figs. 142-147)}

O maior dos dois vermes capturados acusou comprimento de ca. de 25 $\mathrm{mm}$. e largura de $12 \mathrm{~mm}$., no estado vivente. O animal conservado tem 18 $\mathrm{mm}$., ao comprido e largura de $10 \mathrm{~mm}$.. As medidas indicadas na diagnose seguinte referem-se ao maior dos vermes, em bálsamo (Fig. 142). A forma do corpo é um oval largo ; a côr do dorso é acastanhada clara ; a do ventre esbranquiçada-acinzentada.

Os olhos são marginais, tentaculares e cerebrais. Os marginais (m) circundam o corpo inteiro, em oposição às outras Discocelidae. A faixa dêstes olhos é mais larga $(0,5 \mathrm{~mm}$.) na região anterior que na posterior $(0,25 \mathrm{~mm}$.). Além disso, são os olhos marginais anteriores mais numerosos e maiores (diâmetro até $0,028 \mathrm{~mm}$.) que os posteriores (diâmetro até $0,020 \mathrm{~mm}$.). $\mathrm{O}$ menor dos vermes presentes mostra trechos extensos da zona lateral do corpo, em regeneração, e ainda sem olhos. Os olhos tentaculares (j) ocupam as bases dos tentáculos que são elevações minúsculas. Cada grupo, de contorno quasi circular, abrange 33-37 olhos, dirigidos obliquamente para os dois lados, para diante e para trás. O diâmetro dos maiores olhos tentaculares é de $0,085 \mathrm{~mm}$. O Os olhos cerebrais (c) vêem para cima e para baixo. Atingem diâmetro de $0,042 \mathrm{~mm}$. e formam dois grupos frouxos, alongados, de 60-70 olhos cada um. Estendem-se, para diante, muito além do cérebro. Este situa-se imediatamente antes da faringe (f) e é asimétrico, nos dois vermes disponíveis (Fig. 145, c). Um dos lados é mais comprido $(0,488 \mathrm{e}$ $0,415 \mathrm{~mm}$.) que o outro $(0,305 \mathrm{e} 0,353 \mathrm{~mm}$.). Como as medidas não são correspondentes, a asimetria revela-se condicionada por contração irregular, no momento da fixação. Os gânglios extra-cerebrais e os intra-cerebrais ("innere Körnerhaufen" Hadenfeldt 1929, p. 599, 604 f. 12, 16, ikh) destacam-se nitidamente. 
A bolsa da faringe (Fig. 142, f) possue, de cada lado, 9-10 divertículos, em parte ainda sub-divididos. A faringe é ricamente pregueada e de ca. de $8 \mathrm{~mm}$., ao comprido. A bôca (b) liga-se por um curto tubo bucal à extremidade caudal da faringe $O$ poro masculino $(p)$ dista $1,1 \mathrm{~mm}$. da bôca ; o feminino (q), 2,45 mm. desta. Os divertículos intestinais são arboriformemente ramificados, mas sem anastomoses. $O$ intestino principal não mostra células claviformes de Minot.

A epiderme do dorso e a do ventre apresentam-se com a mesma altura que é pequena, e ambas conteem rabditos. A membrana basilar é grossa e, devido à contração na conservação, em certos trechos, extraordinariamente espessa. A musculatura cutânea ventral é mais forte que a dorsal (Fig. 143).

Os testículos são ventrais e, além disso, mediais em relação aos ovários, o que é excepcional. Os dutos eferentes (Fig. 142, d) correm do nível do poro feminino para diante, acompanham o terço posterior da faringe e encurvam-se, no trecho seguinte, novamente para trás. Esta parte é dilatada, de maneira que vesículas seminais accessórias se formam. Estas são tubos compridos, sinuosos e musculosos, e entram na calota ântero-dorsal da vesícula granulorum (Fig. 143, 144, k). As desembocaduras das duas vesículas seminais distam $0,6 \mathrm{~mm}$. uma da outra. A vesícula granulorum, ampla e de parede dobrada, recebe a secreção de glândulas extra-vesiculares, situadas dentro do manto de fibras musculares entrelaçadas, que envolve o átrio (a) e a vesícula granulorum. A comunicação (s) entre a vesícula e o átrio, o duto masculino comum da terminologia de Bock (1913, p. 39), apresenta-se como uma fenda comprida $(0,42 \mathrm{~mm}$.), na preparação total. Nos cortes sagitais, o duto é estreito, na direção ântero-posterior ; mas largo $(0,4 \mathrm{~mm}$.) na dextro-sinistral. Evidentemente, estas posições diferentes da extensão principal do duto são condicionadas pela contração diversa da musculatura atrial.

Da parede caudal do átrio salientam-se um lóbulo direito e outro, esquerdo, no lume atrial. Nos bordos livres dêstes lóbulos e no teto do átrio ao redor da entrada do duto comum, ocorrem numerosos órgãos músculoglandulares (h). A estrutura dêstes (Fig. 146) corresponde à das "vesiculæ granulorum" de Discocelis tigrina (Blanch.) (Lang 1884, p. 247 t. 29 f. 2-4, 10) e aos "saquinhos glandulares" de Adenoplana obovata (Schmarda) (Stummer-Traunfels 1933, p. 3508 f. 33-35). Geralmente, vários dêstes órgãos são envolvidos por um manto comum de fibras musculares ; as palhetas ("prostomes", "Mundstücke", "nozzles") proeminam no átrio. Orgãos semelhantes ocorrem nas Discocelidæ Thalamoplana Laidlaw (1904, p. 133 f. 4,5) e Coronadena Hyman (1940, p. 452 f. 24b), assim como em outras famílias dos Acotylea (Apidioplanidæ) e Cotylea (Boniniidæ).

$\mathrm{O}$ espaçoso átrio abre-se com o poro masculino (p), cuja largura é de $0,09 \mathrm{~mm}$.. Ao lado dêste, e à distância de $0,3 \mathrm{~mm}$. dêle, situa-se uma invaginação da epiderme (r), cuja extensão ventro-dorsal é de $0,085 \mathrm{~mm}$.; a dextro-sinistral, de $0,042 \mathrm{~mm}$.. Apesar de o ápice desta reentrância atingir o epitélio ventral do átrio masculino, o lume dela não se comunica com o atrial (Fig. 147). Inexiste também a ligação com o orifício do átrio, como ocorre em A. obovata. Stummer-Traunfels (1933, p. 3509) considerou como formação anormal êste poro accessório masculino, mas a presença dêle, nos dois exemplares presentes da segunda espécie do gênero Adenoplana, prova o contrário. I função desse poro ignora-se. 
Os ovários são ventrais e começam lateralmente aos testículos. Como êstes, atingem, medialmente, a bolsa faríngea. Os úteros dos vermes disponíveis reconhecem-se apenas como tubos finos (Fig. 142, u) aos lados da metade posterior da faringe, pois os ovos ainda não entraram nêles. Os úteros reunem-se um pouco antes do nível do poro feminino. O duto uterino comum (Fig. 143, y) é ciliado como o são todas as partes das vias eferentes femininas, com exceção da ampola da vesícula de Lang. O duto uterino entra, vindo de diante, na vagina interna (w). Esta corre para a frente, na região dorsal do corpo. O trecho seguinte, o curto duto das glândulas argamassadoras (x), encurva-se para o lado ventral. A secreção das glândulas argamassadoras $(\mathrm{g})$ é fortemente eritrófila, nos cortes corados com hematoxilina-eosina. As células da vagina externa (v) conteem secreção côr de rosa. As glândulas produtoras desta secreção situam-se, como as argamassadoras, no parênquima, mas não se afastam tanto quanto estas da via eferente feminina. A parede da vagina externa é dobrada e bem musculosa.

$\mathrm{O}$ duto $(\mathbf{z})$ da vesícula de Lang é reto e, topograficamente, um alongamento do duto uterino comum. Os calibres do duto e da ampola (Fig. 144, 1) da vesícula de Lang são os mesmos, mas o epitélio do duto é ciliado e baixo, a musculatura, grossa, ao passo que o epitélio da ampola é alto, sem cílios, e a musculatura, aí, fina. A ampola tem forma de ferradura, cujos braços são de $0,78 \mathrm{~mm}$., ao comprido, cada um.

Ocorrência : Ilha de São Sebastião, entre algas do litoral superior ; 2 exemplares maduros, em novembro de 1949.

\section{Discussão de Adenoplana evelinæ}

Adenoplana obovata (Schmarda), estudada por Stummer-Traunfels (1933, p. 3505-3510), foi colecionada no mar caraiba, na costa da Jamáica. E menor $(13 \mathrm{~mm}$.) e os olhos marginais estendem-se apenas até ao nível da extremidade anterior da faringe. Como foi dito na diagnose de $A$. evelinæ, não se conhece, até agora, outra espécie das Discocelidæ com olhos marginais ao redor do corpo inteiro. Com isso, torna-se obrigatória a modificação correspondente da diagnose da família. O número dos divertículos da bolsa faríngea de $A$. obovata é menor, e a vagina externa é mais curta que na nova espécie. A reentrância da epiderme, ao lado do poro masculino, comunica-se, em $A$. obovata, com o orifício do átrio. Este último é mais espaçoso em $A$. evelinæ, e a sub-divisão do mesmo é mais acentuada. Finalmente, reunem-se, em $A$. obovata, os canais seminais e formam um duto ejaculatório, ao passo que as vias eferentes masculinas de A. evelinæ entram separadas na vesícula granulorum.

\section{Familia: Latocestidx Laidla $\vee(1903 a$, p. 7)}

A chave completa dos gêneros desta família pode ser apresentada da maneira seguinte :

1 Vesícula granulorum presente

- Vesícula granulorum falta.

Tronioplana Hyman (1944a, p. 73)

2 Vesícula de Lang ocorre; dutos vaginais ausentes.

- Vesícula de Lang falta; um ou dois dutos vaginais presentes.

3 Corpo em forma de fita ; o aparêlho copulatório masculino dirige-se para trás

Latocestus Plehn (1896, p. 159) 
- Corpo oblongo, não em forma de fita ; o aparêlho copulatório masculino dirige-se verticalmente para o lado ventral Alleena Marcus (1947, p. 102)

4 Sem vesícula seminal; um duto vaginal mediano sáe da vagina interna, caudalmente ao duto uterino comum .. . . . Trigonoporus Lang (1884, p. 502)

- Com vesícula seminal; dois dutos vaginais divergem da vagina externa para trás Pentaplana Marcus (1949, p. 67)

Família : Hoploplanidæe Stummer-Traunfels (1933, p. 3576, 3585) Genus : Hoploplana Laidlaw (1902, p. 303)

\section{Hoploplana divæ, spec. nov. (Fig. 148-151)}

A forma do corpo é largamente oval, sendo os bordos anterior e posterior arredondados. O comprimento do verme conservado é de $4,4 \mathrm{~mm}$. ; a largura, de 2,8 mm.. As Hoploplanidæ pertencem aos Policladidos pouco pigmentados, transparentes, cuja côr é definida pelos órgãos internos (Stummer-Traunfels 1933 , p. 3596). Assim mostra-se também $H$. divæ côr de rosa pálida, no dorso, vendo-se o intestino vermelho por transparência. A coloração não resistiu aos processos de conservação e montagem.

Os tentáculos (Fig. 150, t), de $0,25 \mathrm{~mm}$., ao comprido, em bálsamo, distam $0,95 \mathrm{~mm}$. da margem anterior e são cuspidatos. Os olhos tentaculares situam-se exclusivamente na base dos tentáculos e dirigem-se obliquamente para os dois lados. O diâmetro máximo dêles é de $0,028 \mathrm{~mm}$.. No único exemplar disponível, ocorrem 19 olhos tentaculares em um lado, 20 no outro. Os olhos cerebrais (n) formam dois grupos frouxos antes do cérebro (c). Dirigem-se para cima e para baixo, e atingem o diâmetro de 0,025 mm.. Cada grupo abrange 16-18 olhos cerebrais.

Toda a epiderme do dorso é provida de papilas aproximadamente cilíndricas (Fig. 149, p; Fig. 151), de comprimento de 0,05-0,1 mm., no verme conservado, e de grossura de ca. de $0,03 \mathrm{~mm}$.. As papilas maiores encontram-se na região posterior do corpo. A distância entre as papilas equivale aproximadamente ao comprimento delas. Como se vê pela Fig. 151, as papilas lembram, no corte, muito as de $H$. villosa (Lang), ultimamente estudadas por Stummer-Traunfels (1933, f. 159 na p. 3579). As papilas de $H$. divæ, porém, possuem rabditos (z) que ocorrem regularmente em 3-8 células da sua epiderme distal e aí se originam. São também dermais os rabditos (z) da epiderme, numerosos no dorso e no ventre. Algumas células de secreção eosinófila, talvez, rabditógenas, ocorrem, além disso, no parênquima, mas não parece admissível responsabilizá-las pela produção do grande número de rabditos dorsais e ventrais. Os rabditos adenais, se houver, contribuiriam apenas aumentando a quantidade dos dermais. Aos poucos casos de rabditos adenais que se conhecem dos Polycladida (Corrêa 1949, p. 179) parece dever ser acrescentada ainda $H$. villosa (Kato 1937a, p. 217).

A bolsa da faringe é sub-dividida por divertículos e abriga a faringe (Fig. 149, f), que é riquissimamente pregueada ("Krausenpharynx"), como nas outras espécies do gênero. A secreção eosinófila da faringe origina-se, pelo menos em parte, extrafaringeamente. A bôca (b) situa-se um pouco antes do meio do corpo, à distância de $1,8 \mathrm{~mm}$. do bordo anterior. Células clavivormes de Minot ocorrem no teto do intestino principal. 
Os testículo: são ventrais. Os dutos eferentes (Fig. 148, e) dilatam-se ao nível dos úteros (u), formando vesículas seminais accessórias (j). Destas saem os canais seminais (d), subindo até meia altura do corpo. Pela reunião dos canais origina-se o curto duto ejaculatório (h), cuja dilatação terminal constitue a minúscula vesícula granulorum (y). Nesta insere-se o estilete (s), de $0,06 \mathrm{~mm}$., ao comprido. O estilete atravessa a pequena bolsa penial, por sua vez, separada do espaçoso átrio masculino (a) pela dobrada bainha do penis (k). O orifício masculino (q) dista $0,9 \mathrm{~mm}$. do bordo posterior do corpo.

Os ovários (Fig. 149, o) situam-se ventralmente Os úteros semilunares são curtos, não atingindo o nível da bôca (b). Os dutos uterinos reunem-se dorso-medianamente, entrando na vagina interna (Fig. 148, w). Esta dirige-se horizontalmente para diante. $\mathrm{O}$ duto das glândulas argamassadoras (x) encurva-se em direção ventral e caudal. A vagina externa (v), que é curta, corre, novamente um pouco para diante. O poro feminino (r) dista $0,74 \mathrm{~mm}$. da extremidade posterior do corpo.

Ocorrência : Ilha de São Sebastião, um exemplar maduro entre algas do litoral superior, em novembro de 1949.

A espécie foi denominada em homenagem à nossa estimada colaboradora, Dra. D. Diva Diniz CorrêA.

\section{Discussão de Hoploplana divæ}

O gênero continha, até agora, 7 espécies, das quais duas teem apêndices cutâneos dorsais. São estas $H$. villosa (Lang 1884, p. 441 ; Kato 1937a, p. 216) e $H$. papillosa (Lang 1884 , p. 442). As papilas de $H$. villosa são capilariformes, nos vermes viventes, e, segundo Lang, Kato e Stummer-Traunfels, destituidas de rabditos. Além disso são os olhos cerebrais de $H$. villosa (Kato l. c., f. 7 no texto) mais difusamente dispostos que na espécie atual. Bolsa e bainha peniais inexistem em $H$. villosa como em todas as espécies do gênero até agora descritas.

H. papillosa possue poucos tubérculos, relativamente grandes, restritos à região média do dorso. A côr desta espécie é esbranquiçada, com grandes manchas oblongas, acastanhado-avermelhadas. A zona marginal mostra pontos brancos.

São as seguintes as espécies de Hoploplana com dorso sem apêndices :

$H$. insignis (Lang 1884, p. 442). De côr cinzenta, esbranquiçada, com pontos brancos amarelados que tornam granuloso o dorso. Anterior e posteriormente ocorre uma faixa transversal branca, amarelada. $\mathrm{O}$ intestino, o bordo do corpo e a base dos tentáculos apresentam-se de côr violeta.

H. grubei (Graff 1892, p. 205). Os olhos cerebrais ultrapassam caudalmente o cérebro, atingindo a faringe. $\mathrm{O}$ órgão copulador masculino situa-se atrás do orifício masculino e dirige-se, por consequência, para diante.

H. inquilina (Wheeler 1894) Hyman (1939a, p. 143 ; 1940, p. 476). Tem 6-10 olhos cerebrais, de cada lado. O átrio masculino é mais curto e mais estreito que em $H$. divx.

H. ornata Yeri \& Kaburaki (1918, p. 15). Com faixas transversais, côr de tijolo, no dorso e 6-8 olhos cerebrais em cada grupo. O duto das glândulas argamassadoras dilata-se, formando uma bolsa ("Kittdrüsenbeuel" Bock 1913, p. 41). 
H. cupida Kato (1938, p. 582). Cada grupo dos olhos cerebrais abrange 5 olhos. As vesículas seminais são muito volumosas. Os três trechos da vagina são mais curtos que em $H$. divæ, e o médio dilata-se, formando uma bolsa.

H. inquilina thaisana Pearse (1938, p. 79 ; Hyman 1940, p. 477). Uma sub-espécie de $H$. inquilina, mais tarde (Hyman 1944, p. 7-8) suprimida.

\title{
Subordo : Cotylea Lang (1884, p. 425, etc.)
}

\author{
Família : Pseudoceridæ Lang (1884, p. 3, etc.) \\ Genus : Pseudoceros Lang (1884, p. 538)
}

Pseudoceros evelinæ, spec. nov. (Figs. 152-157)

$O$ verme vivente media $40 \mathrm{~mm}$. de comprimento e $13 \mathrm{~mm}$. de largura, aproximadamente. Os bordos são ricamente pregueados ; os tentáculos, de ca. de 1,5 mm., ao comprido, encurvados para trás, lembrando, quanto à forma, pavilhões de chinchila. A côr é vermelha; tom de morango, no meio ; para os lados, mais escuro, tirante a roxo. Duas orlas marginais demarcam-se nitidamente, a interna, alaranjada, de largura de $0,12 \mathrm{~mm}$. e a externa, preta, da mesma largura. A orla preta é interrompida na região dos olhos dorso-distais (Fig. 153, a) dos tentáculos, deixando aí livre uma área transparente. Tanto na preparação total, em bálsamo, quanto nos cortes, conservou-se a orla preta, mas a côr restante dissolveu-se, quando o animal, fixado com "Susa" quente, foi transferido para álcool. Este tornou-se castanho-avermelhado. Pigmento preto (Fig. 154, pi), disperso no parênquima do lado dorsal, mantém-se nos cortes. Este pigmento não encobre os olhos tentaculares e cerebrais (e).

Os olhos tentaculares (Fig. 155) dispõem-se conforme o tipo agrupado, característico das espécies mais diferenciadas do gênero (Stummer-Traunfels 1933, nota nas páginas 3544-3545). Cada tentáculo possue 4 grupos de olhos, dois dorsais $(a, b)$ e dois ventrais (c, d), dos quais dois são distais (a, c) ; os outros, proximais (b, d). O têrmo "ventral" refere-se à face morfologicamente ventral do animal, exposta na vista dorsal, devido ao dobramento dos tentáculos. O grupo ventro-distal (c) é o mais concentrado e contém ca. de 60 olhos. Sobrepõe-se a êste grupo uma área arredondada do integumento, destituida de pigmento e transparente. Os dois grupos ventroproximais (d) são quasi contíguos no plano mediano, ao passo que os dorsoproximais (b) distam consideravelmente um do outro. Dá-se o mesmo com os dois grupos distais (a, d). O diâmetro máximo é de 20 (a, d) e 30 micra $(b, c)$. Os olhos ventrais (v) dos Cotylea são presentes, mas são ventrais apenas em relação aos olhos cerebrais (e). Estes formam dois grupos anteriormente ligados, de 18 olhos cada um ; o diâmetro máximo dos olhos cerebrais é de 30 micra. O comprimento da área cerebral, que é incolor, é de $0,28 \mathrm{~mm}$. ; a largura, de $0,35 \mathrm{~mm}$.. No lado ventral, corre o sulco sensorial (Fig. 156, w) isento de rabditos, cuja distância do bordo é de $0,7 \mathrm{~mm}$.. Estende-se ca. de $6 \mathrm{~mm}$. para trás. O sulco aproxima-se do bordo, na região dos olhos ventro-proximais (d) e, como é transparente, alarga-se e fornece a janela incolor dêstes olhos. 
A bôca dista ca. de $6 \mathrm{~mm}$. da extremidade anterior e encontra-se atrás do meio da faringe (Fig. 152, f). Esta é rica e finamente pregueada, distando a raiz $3 \mathrm{~mm}$. do bordo anterior ; a orla, 7,6 $\mathrm{mm}$.. As dobras tênues faríngeas acharam-se entremeiadas com grânulos de secreção eosinófila, pois o verme foi fixado, quando estava engulindo Sinascídias. As clavas de Minot do intestino principal apresentaram-se, quasi todas, vazias. Ć́lios ocorrem no intestino principal e nas partes adjacentes dos divertículos, cujas partes laterais não teem cílios. A rede intestinal (i) situa-se, principalmente, na metade dorsal do verme, mas ventralmente aos ovários (ov).

A epiderme dorsal e a ventral são ricas em rabditos (Fig. 154); os cílios são ventralmente mais desenvolvidos. A membrana basilar é forte ; o parênquima frouxo, pauci-celular. O pigmento (pi), já mencionado, apõe-se à musculatura cutânea dorsal. As glândulas (gl) são na região dorsal mais numerosas que na ventral. A ventosa (Fig. 152, x) é volumosa, medindo $1,5 \mathrm{~mm}$. de comprimento, $1 \mathrm{~mm}$. de largura e distando $11 \mathrm{~mm}$. do bordo anterior.

Os poros genitais situam-se entre a faringe (f) e a ventosa $(\mathrm{x})$; os masculinos (y) distam 7,6 mm. da extremidade anterior; o feminino (z), 8,5 mm.. Os ovários (Fig. 154, ov) são dorsais ; os testículos (te), ventrais. Ventrolateralmente reunem-se os dútulos eferentes (de), formando canais seminais moniliformes. O aparêlho copulatório masculino é duplo. As dilatações sucessivas dos canais seminais apresentam-se como vesículas seminais accessórias (Fig. 157, m), separadas, uma da outra, por esfíncteres grossos. Os canais dirigem-se para diante e formam, de cada lado da faringe, uma vesícula seminal principal (l), de parede musculosa. As vias eferentes masculinas dos dois lados não se comunicam. O duto ejaculatório fino (n) corre dentro de um manto espaçoso de músculos que envolve ainda a pequena vesícula granulorum (r). O duto da secreção granulosa (q) e o duto ejaculatório (n) reunem-se na base do cône penial, provido de estilete cuticular (p), curto e reto. A bolsa penial (bo) ou átrio masculino interno circunda o estilete, e uma dobra, a bainha penial (o), separa o penis retraido do átrio masculino (t) ou átrio masculino externo. A configuração dêste é muito singular, pois seis dilatações dobradas alternam com 5 trechos tubulosos, providos de esfíncteres (s). Um sexto esfincter cinge o poro masculino (y). Deve-se supor dilatação e encurtamento do átrio, na copulação, e, destarte, protração do penis. Todo o átrio é ricamente ciliado e contém secreção eritrófila, bacilar, nas células que o revestem. Ectalmente é esta secreção rabdóide produzida nas próprias células atriais; entalmente, no parênquima, especialmente no da bainha do penis. A direção do órgão copulador e átrio masculinos para trás é incomum no gênero Pseudoceros.

Os ovários (Fig. 154, ov) situam-se dorsalmente ao intestino e aí correm também os ovidutos (od), em que espermatozóides (sp) se notam. São, porém, inseminados somente ovos que se encontram nos úteros. Os dois úteros (u) são providos de numerosas ramificações ; dirigem-se para diante, nos dois lados do intestino principal, correndo dorsalmente aos testículos (te), ventralmente aos divertículos intestinais (i). Nos úteros, observam-se divisões de maturação, sendo o número haplóide dos cromosomas 9, como em Thysanozoon brochii (Ruebush 1938, p. 325). O aparêlho eferente feminino (Fig. 157), revestido de ćlios, corresponde ao tipo comum dos Cotylea : 
duto uterino (k), vagina interna, bolsa da secreção argamassadora (h), circundada por massas volumosas de glândulas (g), e pequena vagina externa (j).

Ocorrência : Um exemplar maduro, perto de Santos, no costão do Forte Itaipú. O verme foi colhido durante a vasante máxima, a poucos $\mathrm{cm}$. abaixo da linha da água, sôbre Sinascídias vermelhas (27. VII. 1949).

\section{Discussão de Pseudoceros evelinæ}

As espécies de Pseudoceros habitam os mares quentes e temperadosquentes. Os limites meridionais são as costas da Africa do Sul (St. James, False Bay) e da Austrália oriental (Port Jackson), ignorando-se os pontos correspondentes nas costas pacífica e atlântica sul-americanas. O mar Mediterrâneo e as Bermudas constituem os limites setentrionais. Um achado mais para o Norte, Lat. $41^{\circ} 6^{\prime}$ N., Long. $56^{\circ} 3^{\prime}$ W., refere-se a dois exemplares de $P$. velutinus, espécie mediterrânea, capturada aí em alto mar (Plehn 1896a, p. 9) e transportada talvez da região das Bermudas pela corrente do Golfo. Outra espécie mediterrânea, $P$. splendidus, conhece-se já das Bermudas. No Indico e Pacífico Ocidental, que constituem uma unidade zoogeográfica, representa Mororan (ou Muroran), na costa meridional de Hokkaido, o limite setentrional. A região recebe mais água fria do Oyashio (corrente das Kurilas) do que a quente do Kuroshio e é temperada, não temperada-quente. Morfologicamente a espécie em questão, $P$. yessoensis, não é um Pseudoceros típico, (Kato 1937, p. 38), como tais se conhecem de Hondo e da Coréia, os limites setentrionais indubitáveis. As ilhas dos Galápagos são o único lugar da zona pacífica das duas Américas, onde um Pseudoceros foi encontrado (Plehn 1896, p. 171).

Das águas quentes do Atlântico ocidental conheceram-se, até agora, somente 7 espécies (Marcus 1949, p. 87), das quais apenas uma, P. splendidus, foi verificada também em outras regiões (Galápagos). A nova espécie é a primeira atlântica de côr vermelha e, com isto, pode ser considerada suficientemente discriminada. Ocorrem, é verdade, espécies de côr vermelha no Indopacífico, mas diferem de $P$ evelinæ, pelos olhos, tentáculos e outros caracteres. Mesmo as espécies indopacíficas vermelhas incompletamente descritas distinguem-se, quasi com certeza, de $P$. evelinæ pela procedência remota, pois a grande maioria das espécies de Pseudoceros parece ser apenas regionalmente distribuida.

$\mathrm{Na}$ lista aqui anexa foram as espécies apenas catalogadas. Das diagnoses originais acrescentei caracteres que puderam ser resumidos em poucas palavras, principalmente a côr do lado dorsal e o número, um ou dois, dos aparelhos masculinos. A base bibliográfica quasi completa do catálogo aqui compilado não é suficiente para uma revisão do gênero. Esta necessitaria de um amplo material de Ceilão e de Singapura, de onde Schmarda (1859) e Collingwood (1876) descreveram numerosas espécies.

A uniformidade dos órgãos copulatórios (Bock 1913, p. 253) dificulta a sistematização de Pseudoceros. Todavia, êstes órgãos devem ser estudados (Hyman 1939, p. 19). O número dos penis, um ou dois, pode variar dentro da mesma espécie (Lang 1884, p. 270-271), e támbém o número dos orifícios masculinos não é específico em todos os casos (veja $P$. latissimus). As côres, especialmente os tons vermelhos e amarelos, empalidecem nos líquidos de 
conservação. Manchas e estrias condicionadas pelo conteudo do intestino principal e dos divertículos intestinais, pelos ovários e por pacotes de espermatozóides injetados no corpo, na ocasião da copulação, carecem de valor sistemático. Mesmo a côr fundamental pode variar conforme o substrato e o alimento (Crozier 1917 ; Bock 1927, p. 11 e seg.), mas, em muitas espécies, é relativamente constante e taxonomicamente importante. Vale isto ainda mais para desenhos formados por melanóforos que se manteem nos vermes conservados. A distribuição dos olhos tentaculares como carater sistemático foi, com razão, ressaltada por Stummer-Traunfels (1933, p. 3544-45, notas), mas em espécies muito escuras o pigmento dificulta analisar os olhos. A forma dos tentáculos, embora taxonomicamente valiosa, não é, em todos os casos, genericamente característica, como se vê pela discussão de Prostheceræus (Kaburaki 1923, p. 646) ou Pseudoceros (Palombi 1938, p. 355) papilionis e de outras espécies ainda. O tamanho do corpo figura entre os sinais sistematicamente aproveitáveis (Palombi 1931, p. 7), e certamente com razão. Convem apenas lembrar certa passagem (Lang 1884, p. 541-42) a respeito de $P$ maximus. O exemplar maior, maduro, acusou $8 \mathrm{~cm}$. de comprimento, e houve indivíduos com mais de $5 \mathrm{~cm}$., não maduros, ao lado de outros, maduros, de $4 \mathrm{~cm}$., ao comprido. Ignora-se a parada ou a continuação do crescimento dos Policladidos que atingiram maturidade sexual; todavia a espécie aludida mostra ampla variação do tamanho individual de vermes maduros. A posição da bôca, dos poros genitais, da ventosa e a relação topográfica entre êstes órgãos podem servir na separação das espécies.

\section{Lista das espécies de Pseudoceros}

1) armatus (Kelaart 1858) ; Lang 1884 , p. 545. Purpúreo escuro com pequenos acúleos pretos. Éstes considerou Diesing $(1862$, p. 560) como sendo rabditos proeminentes. A epiderme dorsal das Pseudoceridæ é, realmente, rica em rabditos (Lang 1884, p. 53) e, especialmente, as papilas de Thysanozoon (Stummer-Traunfels 1933, p. 3578; Marcus 1949, p. 82). Provàvelmente tratar-se-á, em armatus e papilionis, de pequenas papilas com muitos rabditos. Heath \& McGregor $(1912$, p. 474) basearam o gênero Licheniplana na presença de curtas papilas dorsais, sem notar que Collingwood $(1876$, p. 86) já tinha procedido do mesmo modo, com Acanthozoon. Recomenda-se revalidar êste gênero.

2) asamusiensis Kato (1939, p. 148), Tentáculos cuspidatos com os olhos espalhados sôbre êles. Bôca na extremidade anterior da faringe. Um poro e um órgão copulador masculinos. A côr dos vermes viventes ignora-se.

3) atropurpureus Kato (1934, p. 129). Purpúreo escuro com pequenos pontos brancos em grande número. Aparêlho masculino simples.

4) aureolineatus Verrill (1901, p. 42) ; Hyman 1939, p. 18. Purpúreo no meio ; os lados brancos com manchas purpúreas, cujos ráios podem ligar-se com o campo colorido central. Bordo alaranjado, tirante a purpúreo ou acastanhado. Um poro masculino e um órgão copulatório.

5) bedfordi Laidlaw (1903, p. 314); Bock 1913, p. 254. Negrejante esverdeado com faixas, linhas e pontinhos brancos amarelados. Dois orifícios masculinos e dois penis.

6) bicolor Verrill (1901, p. 42); Hyman 1939, p. 19. Preto com bordo branco, tirante a acinzentado.

7) bimarginatum A. Meixner (1907, p. 465). Côr de rosa pálida ; o bordo com linha verde, seguida, para dentro,por faixa acastanhada e outra, áurea. Aparêlho masculino simples.

8) buskii (Collingwood 1876, p. 91); Lang 1884, p. 547. Aveludado oliváceo com bordo a marelo pálido. O verme que Kaburaki (1923, p. 641) classificou como buskii tem côr completamente diferente e pertence, ao nosso vêr, a uma outra espécie. 
9) cæruleo-punctatus Palombi (1928, p. 605). Côr de creme amarelada; o bordo com manchas azuis escuras. Cada mancha com auréola azul radiada. Os ráios não se anastomosam, de maneira que a côr fundamental amarelada aparece entre as manchas. Órgão masculino simples.

10) cardinalis Haswell (1907, p. 480). Vermelho escarlate vivo. Tentáculos muito pequenos. Faringe campanuliforme, sem dobras. Um poro masculino e um penis.

11) cardiosorus (Schmarda 1859, p. 28) ; Stummer-Traunfels 1933, p. 3540 f. 97, 98. Acastanhado amarelado com faixa mediana avermelhada. Um poro masculino e um órgão copulador.

12) cerebralis (Kelaart 1858); Lang 1884, p. 546. De côr clara acastanhada amarelada, com finas linhas onduladas castanhas. O bordo, preto com risquinhos brancos.

13) chloreus Marcus (1949, p. 86). Amarelo esverdeado com faixa ântero-mediana côr de sépia, posteriormente dissolvida em manchas. De cada lado da linha mediana duas outras séries de manchas da mesma côr.

14) cinereus Palombi (1931, p. 5). Cinéreo com bordo preto e uma estria cinzenta escura de cada lado da entumescência dorso-mediana. Dois orifícios masculinos e dois penis.

15) clavicornis (Schmarda 1859, p. 32) ; Stummer-Traunfels 1933, p. 3543 f. $106,107$. Violáceo escuro com faixa amarela ao redor do bordo, mas disposta internamente a êste. Aparêlho masculino simples.

16) collingwoodi Laidlaw (1903, p. 314). Com marmorização castanha-escura e brancaacastanhada. O bordo externo, uma estreita linha branca internamente acompanhada por outra, preta, igualmente fina. Lembra cerebralis e striatus (Kel.), mas é muito menor que ambas. Um poro masculino e um órgão copulador.

17) concinnus (Collingwood 1876, p. 90). Apesar de corresponder a forma dos tentáculos ao tipo conum em Prostheceræus, incluiu Kaburaki (1923, p. 642) a espécie no gênero Pseudoceros. Côr de creme amarelada, com bordo azul e uma faixa azul de cada lado da linha mediana.

18) crozieri Hyman (1939, p. 17). O dorso é branco, alaranjado, amarelado pálido, acastanhado ou esverdeado ; atravessam-no numerosas linhas pretas, em parte onduladas, em parte terminando com manchas bulbiformes. Aparêlho masculino simples.

19) devisii Woodworth $(1898$, p. 63). Alaranjado amarelado vivo, com bordo alaranjado escuro.

20) dimidiatus Graff 1893 (veja Graff 1904-08, p. 1888 n.‘ 1007). Não descrito (Haswell 1907 , p. 465), mas caracterizado pela procedência (Great Barrier Reef) e a figura em côres, não vista por mim. Segundo Laidlaw (1903a, p. 11), dimidiatus tem dorso preto.

21) exoptaius Kato (1938, p. 587). Violáceo negrejante claro, com linha mediana tirante a castanho. Todo o dorso com pequenas manchas brancas indistintas ("mottles"). O bordo, purpúreo escuro. Um poro masculino e um órgão copulador.

22) flavomaculatus Graff (1904-08, p. 1888 n." 1007). Evidentemente um êrro tipográfico da referata. A espécie aludida é Prostheceræus flavomaculatus Graff 1893 (Haswell 1907 , p. 465).

23) flavomarginatus Laidlaw (1902, p. 298). Preto aveludado com margem larga, alaranjada. Aparêlho masculino simples.

24) gamblei Laidlaw (1902, p. 297). Lácteo ou côr de carne transparente com bordo purpúreo ou azul escuro. Um orifício masculino e um órgão copulador. A forma da faringe corresponde à do gênero Dicteros Jacubowa (1906, p. 32).

25) gardineri Laidlaw (1902, p. 296). Cinzento delicado, na figura amarelado, com manchas pretas irregularmente distribuidas e de vários tamanhos. Dois orifícios masculinos e dois penis.

26) gratus Kiato (1937a, p. 227). Lácteo com bordo preto. Uma faixa preta no meio e duas nos dois lados, não longe do bordo, reunidas posteriormente. Aparêlho masculino duplo.

27) gravieri A. Meixner (1907, p. 468). Com faixas amarelas douradas, orladas por outras, azuis escuras. $\mathrm{O}$ bordo do corpo, azul mais claro. Um orifício masculino e um penis.

28) haddoni Laidlaw (1903a, p. 10). Alaranjado-amarelado mate, com largo bordo preto orlado por linha amarela externa. Tentáculos pequenos. 
29) hancockanus (Collingwood 1876, p. 91). Classificado como Prostheceræus por Lang (1884, p. 567), como Pseudoceros por Kaburaki (1923, p. 639). Os tentáculos figura V a de Collingwood são de Prostheceræus. O verme descrito por Kaburaki figura, na lista presente, sob malayensis que é um Pseudoceros. Os caracteres de hancockanus são: Dorso acastanhado escuro, aveludado, com bordo formado por duas faixas de largura igual, a interna alaranjada carregada ; a externa, branca opaca. Tentáculos compridos e graciosos ("graceful").

30) kelaartii (Collingwood 1876, p. 92). Lang (1884, p. 568) aproximou kelaartii a Prostheceræus. Laidlaw (1903, p. 314) chamou a espécie Pseudoceros kelaartii, o que parece admissível. O dorso purpúreo escuro com marmorização esbranquiçada e entumescência mediana mais escura que o resto.

31) kentii Graff 1893 (veja Graff 1904-08, p. 1888 n. ${ }^{\circ}$ 1007). Espécie não descrita (Haswell 1907, p. 465), mas caracterizada pela procedência (Great Barrier Reef) e a figura colorida, não vista por mim. Tendo relações relativamente íntimas ("somewhat closely allied") com P. regalis Laidlaw (1903a, p. 10), suponho que tem côr de tijolo, bordo preto e tentáculos pequenos.

32) lacteus (Collingwood 1876, p. 90) ; Lang 1884, p. 548. Côr de creme com pontos pretos, pequenos e escassos. De cada lado da entumescência mediana muito saliente há fraca marmorização. O bordo com manchas vermelhas irregulares e orlado por linha preta. Aparêlho masculino simples (Yeri \& Kaburaki 1918, p. 37).

33) latissimus (Schmarda 1859, p. 31) ; Stummer-Traunfels 1933, p. 3542 f. 103-105. Amarelo avermelhado com faixa mediana acastanhada escura e manchas, da mesma côr, pequenas e redondas. Um e dois orifícios masculinos e um e dois penis foram verificados.

34) leptostictus Bock (1913, p. 256). Corpo consistente. Côr (em álcool) como areia amarela, marcada com pontos pretos. Lateralmente, mais avermelhada; no meio, mais amarela pura. O bordo com manchas pretas quadrangulares, separadas umas das outras pela côr fundamental. Tentáculos pretos, com excepção das pontas.

35) limbatus (Leuckart 1828); Lang 1884, p. 544. Verde esbranquiçado com bordo externo branco acompanhado por interno, preto. A faixa mediana, côr de sangue, poderia ser conteúdo do intestino principal, pois pigmentos vermelhos geralmente não ocorrem, em Pseudoceros, combinados com côr fundamental esverdeada.

36) liparus, nom. nov. (pro limbatus Haswell 1907, p. 480 ; non limbatus Leuck.). Vermelho claro com faixa marginal purpúrea bem definida. Bôca imediatamente atrás do cérebro. O único penis dirige-se para trás, o que é raro (yessoensis) em Pseudoceros.

37) litoralis Bock (1913, p. 259) ; Kaburaki 1923, p. 640. Côr (em álcool) acastanhada negrejante com faixa marginal amarela-cromo, disposta a certa distância do bordo. Êste com orla acastanhada-preta. Aparêlho masculino simples.

38) luteomarginatus Yeri \&"Kaburaki (1918, p. 37). Preto aveludado com bordo externo acastanhado escuro e mate, acompanhado por faixa interna amarela clara. Dois orifícios masculinos e dois penis.

39) maculatus (Pease 1860, p. 38) ; Lang 1884, p. 547. Amarelado ou esverdeado com manchas esverdeadas circundadas por anéis brancos. A côr fundamental torna-se alaranjada para os lados.

40) maculosus Pearse (1938, p. 85). Cinzento com faixa mediana clara, orlada por debrum escuro. Ca. de 135 pequenas manchas escuras. Bordo do corpo, claro. Is pequenas papilas dorsais recomendariam remover a espécie para o gênero Acanthozoon Collingw. (Licheniplana Heath \& McGreg. ; veja espécie n." 1), mas não se destacaram mais (Hyman 1940, p. 485) na preparação total do material original. Aparêlho masculino simples.

41) malayensis (Collingwood 1876, p. 56 $)$ ); Bock 1913, p. 258 ; Kaburaki 1923, p. 639: hancockanus. Pertence a Pseudoceros, ao passo que hancockanus (Collingw.), apesar de ser da mesma côr, parece ser um Prostheceræus. Acastanhado-preto, aveludado ; a linha mediana mais escura ainda. No bordo uma estreita orla esbranquiçada externa e outra interna, também estreita, amarela-cromo escura.

42) marmoratus Plehn (1898a, p. 145). Com marmorização negrejante, entumescência mediana bem marcada, especialmente escura e bordo estreito, amarelo claro. Um orifício masculino e um penis.

43) maximus Lang (1884, p. 541). De côr variável: amarelada, acastanhada, às vêzes tirante a azulada ou roxa-acastanhada escura. O bordo pode ser orlado por debrum 
acastanhado escuro. Manchas irregulares, em parte ligadas em forma de fita, ora mais escuras que a côr fundamental, ora brancas ou esbranquiçadas. Um orifício masculino e um penis.

44) memoralis Kato (1938a, p. 569). Côr de carne esbranquiçada com pequenos pontos pretos. O bordo com 3 faixas, a externa estreita, verde esmeralda ; a média, larga, preta ; a interna, também larga, amarelada-acastanhada. As 2 faixas sub-marginais interrompidas por estreitas linhas lácteas. Aparêlho masculino simples.

45) microceræus (Schmarda 1859, p. 31) ; Stummer-Traunfels 1933, p. 3541 f. 101-102. Amarelo, côr de barro, com numerosas pequenas manchas castanhas e bordo amarelo. Um orifício masculino.

46) micropapillosus Kato (1934, p. 130). Vermelho com poucas manchas brancas irregulares e numerosos pequenos pontos, também brancos. Aparêlho masculino simples. As papilas recomendam seja incluída a espécie no gênero Acanthozoon Collingw. (Veja espécie n.' 1).

47) miniatus (Schmarda 1859, p. 27) ; Stummer-Traunfels 1933, p. 3539 f. 90-91. Vermelho, côr de óxido de chumbo (zarcão), com linha mediana escura e manchas brancas indistintas. O bordo, azul escuro para fora, branco azulado para dentro. Dois orifícios masculinos e dois penis.

48) mülleri (Delle Chiaje 1829); Lang 1884, p. 545. Vermelho escuro com linha mediana branca.

49) nigrocinctus (Schmarda 1859, p. 26); Stummer-Traunfels 1933, p. 3538 f. 88-89. Vermelho pálido com manchas violáceas-castanhas, bordo preto e linha mediana esbranquiçada.

50) nigromarginatus Yeri \& Kaburaki (1918, p. 39). Acastanhado negrejante com duas faixas longitudinais claras e bordo negrejante estreito. Dois orifícios masculinos e dois penis.

51) papilionis (Kelaart 1858); Lang 1884, p. 546. Collingwood (1876, p. 95) alterou em papilio o nome específico original, mas isto não se justifica. Amarelo com pontinhas pretas ; o bordo esbranquiçado. Aparêlho masculino simples (Palombi 1938, p. 356-357). Segundo Collingwood (1. c.), a espécie deveria ser removida para Acanthozoon Coll. (=Licheniplana Heath \& McGreg.), mas nem Kaburaki (1923, p. 646) nem Palombi (l. c.) mencionam papilas, falando apenas em pontos pretos. $O$ material de Kaburaki tem côr diferente dos vermes de Collingwood e de Palombi. Não sigo Kaburaki na transferência de papilionis para Prostheceræus.

52) paradoxus Bock (1927, p. 17). Sem pigmento ; côr de rosa transparente.

53) pardalis Verrill (1900, p. 596). Acastanhado com manchas amarelas.

54) periphæus Bock (1913, p. 255). Vermelho com bordo azul-preto, mais largo nos tentáculos. Êstes são dobras grandes, mas simples, nem alongadas, nem engrossadas. Aparêlho masculino simples.

55) philippinensis Kaburaki (1923, p. 645). Preto com tons purpúreos e linha mediana purpúrea clara ; esta acompanhada, de cada lado, por uma faixa cinérea. O bordo alaranjado-cromo por fora e esbranquiçado mais para dentro. Possivelmente dois aparelhos masculinos.

56) pius Kato (1938a, p. 570). Amarelo claro com retículo denso de pequenos grânulos vermelhos e outros, purpúreos negrejantes. Manchas da última côr, mas de maior tamanho, distribuidas sôbre o retículo. Um orifício masculino e um penis.

57) pleurostictus Bock (1913, p. 257). Côr (em álcool) branca amarelada com faixas transversas pretas, radialmente dispostas. Os tentáculos são dobras engrossadas, mas não grandes. Do bordo anterior corre para os olhos cerebrais uma faixa longitudinal curta que se bifurca, dirigindo-se para os dois lados.

58) punctatus Laidlaw (1902, p. 296). Amarelo pálido acinzentado com pontos pretos, pequenos e regulares. Dois orifícios masculinos e dois penis.

59) regalis Laidlaw (1903a, p. 10). Vermelho, côr de tijolo, lateralmente mais carregado e com orla marginal preta, muito estreita. Tentáculos pequenos. Um orifício masculino e um penis.

60) reticulatus Yeri \& Kaburaki (1918, p. 35). Retículo formado por faixas largas oliváceas ; as malhas bem mais claras. Pequenos pontos pretos uniformemente distribuidos no dorso. A faixa mediana escura com séries de curtas linhas incolores. Aparêlho masculino simples. 
61) rubellus Laidlaw (1903, p. 314). Vermelho-magenta, semelhante à côr de kelaartii. Comprimento de $5 \mathrm{~mm}$., largura de $4 \mathrm{~mm}$., no estado conservado. Apesar da pequenez dos vários exemplares colecionados, a maioria estava madura. Aparêlho masculino simples.

62) rubrocinctus (Schmarda 1859, p. 26); Stummer-Traunfels 1933, p. 3538 f. 86, 87. Preto esverdeado ou preto aveludado com escassos pontos brancos e bordo vermelho escarlate. Dois orifícios masculinos e dois penis.

63) rubrotentaculatus Kaburaki (1923, p. 643). Côr de creme com bordo azul, tentáculos vivamente alaranjados e três faixas vivamente amarelas avermelhadas, uma no meio e duas nos dois lados. Aparêlho masculino simples.

64) sagamianus Kato (1937b, p. 362 ; 1939a, p. 76). Acastanhado, no meio mais escuro e com manchas brancas, de forma e tamanho diferentes. $\mathrm{O}$ bordo preto é estreito. Um orifício masculino e um penis.

65) splendidus Stummer-Traunfels (1933, p. 3487, nota). Preto azulado com tons violáceos. $\mathrm{O}$ bordo internamente alaranjado claro, externamente preto azulado. Dois orifícios masculinos e dois penis.

66) striatus (Kelaart 1858); Lang 1884, p. 546. Acastanhado-purpúreo com listras castanhas. Bordo estreito, castanho escuro.

67) strigosus, nom. nov. (pro striatus Schmarda 1859, p. 27 ; non striatus Kel.) ; StummerTraunfels 1933, p. 3540 f. 95, 96. Amarelo com 3 faixas castanhas longitudinais, a mediana mais larga, as duas laterais mais estreitas. $\mathrm{O}$ bordo, acastanhado escuro ou preto. Dois orifícios masculinos e dois penis.

68) superbus Lang (1884, p. 540). Figura na lista presente sob splendidus, pois Eurylepta superba Schmarda (1859, p. 28) pertence ao gênero Pseudoceros (Stummer-Traunfels 1933, p. 3541 f. 99-100), e, por isso, $P$. superbus Lang tinha de receber um nome novo (splendidus). P. superbus (Schmarda) figura aqui sob undulatus (Kelaart), conforme a sinonímia estabelecida por Lang (1884, p. 552).

69) susakiensis Kato $(1934$, p. 131). Alaranjado com manchas acastanhadas amareladas, escassas e pequenas. Duas crescentes castanhas escuras ao nível dos olhos cerebrais. O bordo, incolor. Aparêlho masculino simples.

70) tigrinus Laidlaw (1902, p. 297). Côr fundamental alaranjada-rosácea. Faixas pretas com manchas côr de rosa e finos pontos brancos. Os tentáculos e o bordo, pretos. Um orifício masculino e um penis.

71) tomiokaensis Kato (1938a, p. 568). Côr não conservada. Numerosos olhos dispostos em séries regulares no bordo das dobras tentaculares, em cuja base um grupo de olhos cerebrais se situa. Um orifício masculino e um penis.

72) undulatus (Kelaart 1858) ; Lang 1884, p. 552. Amarelo com faixa mediana, manchas e bordo de côr purpúrea-violácea. Dois orifícios masculinos e dois penis, verificados por Stummer-Traunfels (1933, p. 3541) em $P$ superbus (Schmarda), sinônimo de undulatus (Kel.).

73) velutinus (Blanchard 1847, p. 273) ; Lang 1884, p. 538. Preto azulado aveludado com campo claro até branco ao redor dos olhos cerebrais. Aparêlho masculino simples.

74) violaceus (Schmarda 1859, p. 27) ; Stummer-Traunfels 1933, p. 3539 f. 92-94. Violáceo escuro. Faringe ricamente pregueada ("Krausenpharynx"). Um orifício masculino e um penis.

75) vinosun A. Meixner (1907, p. 470). Violáceo escuro avermelhado com manchas brancas (grupos de espermatozóides injetados) e amarelas (ovários). $\mathrm{O}$ bordo escuro vermelho-violáceo. Aparêlho masculino simples.

76) viridis (Kelaart 1858 ; Schmarda 1859, p. 32); Lang 1884, p. 567 (Prostheceræus) ; Stummer-Traunfels 1933, p. 3543 f. 108, 109 (Pseudoceros). Verde com manchas e bordo de côr acastanhada clara. Pequenas manchas brancas difusamente distribuídas no dorso. Dois orifícios masculinos e dois penis.

77) yessoensis Kato (1937, p. 37). Ém álcool, lácteo com denso retículo preto ; o bordo sem pigmento. Aparêlho masculino simples. O grupo alongado dos olhos cerebrais e o penis dirigido para trás isolam a espécie de certo modo das outras do gênero.

78) zebra (Leuckart 1828); Lang 1884, p. 544. Violáceo claro com faixa mediana branca e faixas transversais igualmente brancas. $O$ bordo, alaranjado.

79) zeylanicus (Kelaart 1858) ; Lang 1884, p. 546. Purpúreo escuro e acastanhado, côr de chocolate. $O$ bordo, de fora para dentro, branco, alaranjado e preto. 


\section{Família : Euryleptidæ Lang (1884, p. 553) \\ Genus : Cycloporus Lang (1884, p. 568) \\ Cycloporus gabriellæ, spec. nov. (Figs. 160-166)}

O corpo dos vermes viventes é foliáceo, e de ca. de $7 \mathrm{~mm}$., ao comprido. Anteriormente, destacam-se os curtos tentáculos em ponta ("Zipfeltentakel" Stummer-Traunfels 1933, p. 3581 ; Cycloporus : p. 3583) ; posteriormente, o corpo termina em cúspide (Fig. 158). Depois da conservação, o corpo apresenta-se escutiforme, sendo o comprimento de $5 \mathrm{~mm}$.; a largura de $4 \mathrm{~mm}$.. Os tentáculos contraidos salientam-se pouco no bordo anterior ; a ponta caudal não se observa mais. A ventosa é volumosa, de $0,45 \mathrm{~mm}$. de diâmetro, no estado retraido ; situa-se imediatamente atrás do meio do corpo.

A côr dos vermes viventes é determinada pelo intestino, cujas ramificações acastanhado-negrejantes transparecem através da epiderme lisa e diáfana. Pontos brancos, os ovários, sobrepõem-se ao desenho escuro, havendo ainda manchas amarelas, na região anterior do corpo. O ventre é claro, opaco.

De olhos tentaculares (Fig. 159, o) distinguem-se 4 grupos, 2 dorsais e 2 ventrais, nitidamente separados no meio. Cada grupo ventral contém, aproximadamente, 20 olhos ; o dorsal, 10. O diâmetro máximo dos olhos tentaculares é de $0,025 \mathrm{~mm}$.. Os olhos cerebrais (n) formam dois grupos, largamente triangulares. Os mais posteriores dêstes olhos sobrepõem-se à bolsa da faringe (f), e os anteriores convergem para diante. Os olhos ventrais situam-se em baixo dos cerebrais. Cada um dos grupos cerebrais contém ca. de 30 olhos. O diâmetro dos maiores dêstes é de $0,034 \mathrm{~mm}$..

$\mathrm{O}$ cérebro (Fig. 160, c) é provido de gânglios pré-cerebrais $(\mathrm{m})$ e situa-se imediatamente antes da bôca (b). A faringe (f) campanulada, curta e grossa, mede $0,7 \mathrm{~mm}$. de comprimento. O intestino principal (j) é nitidamente delimitado ; emite para diante um ramo impar (i), sobreposto ao cérebro (c) e, além disso, 10 pares de divertículos (Fig. 158), a saber, 1 par anterior, que flanqueia o ramo impar, e 9 pares laterais e látero-caudais. Os divertículos ramificam-se dicotômica e repetidamente, mas não se anastomosam. As vesículas terminais comunicam-se com as últimas ramificações dos divertículos do mesmo modo como em C. papillosus (Lang 1884, p. 157), i. é, através de uma simples constrição separadora ou por mais um curto canalículo intercalar. Em C. variegatus, o tubo capilar, que liga a vesícula terminal com a extremidade periférica dos divertículos, é muito comprido (Kato 1934 , f. 13 no texto da p. 134).

$\mathrm{O}$ orifício externo das vesículas terminais destaca-se dentro da epiderme muito mais nos cortes transversais do nosso material (Fig. 161, 162) do que nos desenhos de Lang (1884, t. 27 f. 2-6). O poro é delimitado por células epidérmicas sólidas, sem rabditos. Fibras musculares finas, mas numerosas (e), seguram as vesículas. Algumas destas achavam-se estendidas, no momento da fixação (Fig. 161), outras, meio-vazias e vazias (Fig. 162). Lang $(1884$, p. $157-158,161)$ viu a passagem de gotas e de restos da comida pelas vesículas e seus poros, mas o nosso material não mostrou fezes nas vesículas. A comunicação da vesícula com o divertículo intestinal $(\mathrm{k})$ realiza-se por um canal intracelular que corre dentro de duas células sucessivas (d). O 
orifício externo dêste canal é fechado por uma terceira célula (t), a célula oclusora. Os desenhos de Lang não entram nêstes pormenores; todavia é possível reconhecer os elementos descritos no corte horizontal, reproduzido por Bresslau (1933, f. 76 na p. 90), e supôr que as vesículas de C. papillosus se assemelhem às de C. gabriellx.

A epiderme é destituida de papilas ; a dorsal é um pouco mais grossa que a ventral. Rabditos e glândulas são dorsais e ventrais ; rabditos são ântero-ventralmente muito numerosos. A musculatura ventral é mais grossa que a dorsal.

Os testículos são ventrais, sub-intestinais ; os ovários, dorsais, supraintestinais. Os dutos eferentes entram separados e vindos de trás na calota caudal da vesícula seminal (Fig. 160, s). Da região anterior desta vesícula esférica e musculosa sái o duto ejaculatório (w) que é curto. Ao entrar na papila do penis $(\mathrm{x})$, recebe o dútulo da vesícula granulorum (r). A ponta da papila é fracamente cuticularizada. A bainha penial ( $\mathrm{z}$ ) tem comprimento igual à papila do penis, circundada pela bolsa (y). O átrio masculino (a), pouco espaçoso, abre-se com o poro (p), perto da bôca (b).

Também os caracteres dos órgãos femininos enquadram-se bem no esquema conhecido das Euryleptidæ (Lang 1884, t. 30 f. 15). Os úteros e suas glândulas ainda não se reconhecem no material disponível.. Os dois dutos uterinos, que se reunem formando o duto uterino comum (u), as glândulas argamassadoras (g) e a bolsa (v) delas correspondem ao esquema citado.

Entre algas do litoral superior encontrámos a larva desta espécie, que é uma larva de Müller (Fig. 163, 164) com os oito lóbulos tipicamente desenvolvidos. $O$ parênquima dela contém pigmento verde. $O$ verme jovem, recem-metamorfoseado (Fig. 165), ainda não possue o número específico de divertículos intestinais.

Ocorrência : Ilha de São Sebastião, 5 exemplares entre algas crescidas, em parte, nas rochas do litoral superior, em parte, em fundo lodoso, abaixo da linha da vasante máxima.

O nome da espécie foi escolhido em homenagem à memória da nossa querida aluna, Dra. D. Gabriella P. Zuccari.

\section{Discussão de Cycloporus gabriellæ}

O intestino de C.papillosus (M. Sars) possue 6-7 pares de divertículos. Estes mostram anastomoses entre as suas ramificações mais próximas do intestino principal (Lang 1884, p. 138 t. 26 f. 1, ada). Lateral ou perifericamente às anastomoses centrais, os divertículos continuam apenas ramificados, geralmente, sem anastomoses ulteriores. Por isso, encontra-se, no resumo das diagnoses dos gêneros (ibid., p. 431), a passagem algo ambígua : "ramos intestinais não ou somente pouco anastomosados" As anastomoses do intestino de $C$. papillosus foram também mencionadas por Gamble (1893, p. 506), Francotte (1898, p. 256, 297 : na explicação da fig. 38) e Yeri \& Kaburaki (1918, p. 40). Os divertículos intestinais anastomosam-se igualmente em C. variegatus Kato (1934, p. 133).

C. gabriellæ possue 10 pares de divertículos intestinais arboriformemente ramificados, mas não anastomosados. Outro carater separa a nova espécie mais facilmente dos espécimes europeus de C. papillosus, a saber os 
grupos curtos (gabriellæ) e muito compridos (papillosus) dos olhos cerebrais. Nêste pormenor, o material do Japão (Yeri \& Kaburaki, l. c. ; Kato 1937a, p. 229) não concorda com o europeu. Foi chamado papillosus var. misakiensis Kato (1939, p. 149), mas merece, evidentemente, ser considerado espécie à parte. Distingue-se de gabriellæ pelos caracteres do intestino acima indicados, i. é, o número de divertículos e as anastomoses.

C. maculatus Hallez (1894; veja Graff 1904-08, p. 1850), da costa franceza setentrional, deve ser acrescentado (Hallez 1904, p. 49-50) à lista dos sinônimos (Bock 1913, p. 263) de papillosus.

\section{Uma larva de Cycloporus gabriellæe com órgãos generativos}

Juntamente com a larva das Fig. 163-164 e o verme recem-metamorfoseado (Fig. 165) encontrámos, entre algas do litoral superior da ilha de São Sebastião, uma larva de Müller com órgãos reprodutivos masculinos (Fig. 166). A vesícula seminal (s), repleta de espermatozóides móveis, ressaltou-se na larva vivente. Não teríamos tentado criar um único exemplar, de meio milímetro de comprimento, no laboratório, e ainda menos nas instalações disponíveis na práia. Tanto mais procurámos entrosar comparativamente o achado.

Isto não era difícil. O tamanho do animal, de 0,52 mm., entrepõe-se entre o da larva sem órgãos reprodutivos $(0,51 \mathrm{~mm}$.) e o do verme recemmetamorfoseado $(0,54 \mathrm{~mm}$.). A côr da larva sexuada é verde-escura e condicionada por grânulos situados no parênquima. A mesma côr, em distribuição idêntica, ocorre na larva esteril, no verme da Fig. 165 e em vermes de 1-2 mm., ao comprido, jovens e imaturos. Estes vermes de parênquima verde-escuro foram de suma importância para a definição específica da série inteira. Mostrando pequeno número de vesículas intestinais periféricas definiram-se como pertencentes ao gênero Cycloporus. Com isto, também as fases precedentes tornaram-se identificáveis.

O corpo da larva sexuada é mais achatado (Fig. 166) que o da fase anterior, que corresponde ao estádio D de Lang (1884, t. 39 f. 7-9). Os oito lóbulos ciliados reconhecem-se ainda, mas são menores que na larva da Fig. 163. Evidentemente, são regressivos. A configuração externa da larva sexuada corresponde, destarte, ao estádio E de Lang (l. c., f. 10-11).

Rabditos existem em pequeno número. Os olhos (e) passam da larva à fase metamorfoseada. $\mathrm{O}$ cérebro (c), de diâmetro de $0,08 \mathrm{~mm}$., é muito volumoso em relação ao corpo. Este fenômeno é geral em Turbelários jovens. Ventral e post-oralmente esboça-se o primórdio da ventosa (v). Células vesiculosas e outras, eritrófilas, ocorrem no parênquima. Para poder ressaltar os outros órgãos internos, suprimimos, na figura, os numerosos núcleos do parênquima. Provavelmente pertencem às células formadoras do futuro intestino. $O$ trato alimentar funcional (i) apresenta-se histologicamente simples, menos diferenciado que o do estádio D das Pseudoceridæ (Lang 1884, t. 38 f. 2). Deve-se isto, provavelmente, aos volumosos órgãos copulatórios, pré-faríngeos, cuja posição dificulta o desenvolvimento da faringe. O primórdio desta última (f) e da bolsa faríngea (a) existem. Esboçam-se também na larva da Fig. 164, formando-se, segundo Lang (1884, p. p. 390) já na fase C. 
Na parte posterior do corpo ocorrem 1-5 folículos testiculares (t), dificilmente contáveis nos cortes. Trechos dos dutos eferentes reconhecem-se. A maturidade dos testículos evidencia-se pelos espermatozóides móveis na vesícula seminal (s). Esta situa-se dentro do anel do primórdio faríngeo e pré-oralmente. No animal metamorfoseado, é post-oral. Dá-se o mesmo com o penis (p) e o átrio (d) larvais, ambos post-orais no verme adulto de C. gabriellæ. A bainha do penis (z) circunda o órgão copulatório, como foi descrito na diagnose da espécie, mas vesícula granulorum não existe na larva Faltam também quaisquer vestígios dos órgãos femininos, de maneira que não sabemos se há proterandria pronunciada ou separação dos sexos, na larva.

$\mathrm{O}$ verme recem-metamorfoseado e os vermes jovens restantes do nosso material são estéreis, sem restos ou primórdios de órgãos reprodutivos. Estes conhecemos somente do verme anteriormente descrito, de $7 \mathrm{~mm}$, ao comprido. Daí deduzimos possuir Cycloporus gabriellæ duas fases reprodutivas, uma larval e outra, adulta, separadas pelo estádio juvenil estéril. De Ctenóforos e certas Nereidæ conhece-se êste tipo de reprodução, a chamada dissogonia. Se a dissogonia de Cycloporus gabriella ocorre regular ou excepcionalmente, ignoramos ainda.

\section{Considerações sôbre Graffizoon}

A larva descrita evocou, imediatamente quando foi encontrada entre as algas do litoral, a imagem de Graffizoon lobatum Heath (1928). Este animal tém o corpo de uma larva de Müller com órgãos masculinos e femininos. O tipo do aparêlho reprodutivo de Graffizoon foi aproximado ao das Euryleptidæ (Meixner 1930, p. 3480 ; Bock 1931, p. 282). A espécie foì encontrada no plancton da baía de Monterey, na Califórnia, onde mais de 50 exemplares foram obtidos, em vários estádios de idade e com 0,57-0,73 mm. de comprimento. Na interpretação de Graffizoon lobatum, Heath (p. 197-202) pondera duas possibilidades, inclinando-se para a segunda.

1) $O$ animal representa o descendente de Turbelários ancestrais, de vida pelágica. A configuração dêstes seria hoje lembrada pelas larvas de Müller dos Polycladida Cotylea. Segundo esta hipótese, a relação entre as Graffizoidæ e os Turbelários restantes seria a mesma que a entre os Appendicularia (Perennichordata) e os outros Tunicados (Caducichordata).

Na literatura que segue a Heath, esta primeira possibilidade não foi mais ventilada. Deve-se isto, provavelmente, à premissa, i. é, à construção hipotéca de Turbelários primitivos com feição de larva de Müller. Este lobulado arquiplatelminto não pôde interessar aos muitos zoólogos que derivam os Turbellaria dos Cnidaria, por meio dos Acœla e da plânula, nem aos poucos que fazem descender os Turbelários dos Ctenóforos, através dos Policladidos. Por isso, uma "protrochula" planctônica como Turbelário ancestral ficou de lado.

2) Graffizoon lobatum é uma larva dos Cotylea que não se desenvolve mais, por se tornar sexualmente madura, "a case of pædogenesis" Pedogênese significou, originalmente, qualquer modalidade de reprodução no estado juvenil ou larval. Posteriormente, a significação do têrmo restringiu-se à reprodução partenogenética (não "asexual" ; Carter 1940, p. 410) em jovens e larvas. Exemplos de pedogenese, como as larvas das Cecido- 
myidæ, os esporocistos e rédias dos Trematodes Digenea, mostram que estádios pedogenéticos não são denominados com nomes genéricos e específicos. Estes aplicam-se a animais adultos. Visto que Heath usa a nomenclatura zoológica em Graffizoon lobatum, considerando-o até "the genotype" de uma família (Graffizoidæ, p. 203), manifesta que o julga adulto, definitivo. Os caracteres larvais, que chamou de pedogenéticos, entende como neotênicos. A literatura didática de língua inglesa, às vezes, não separa "pædogenesis" e "neoteny" (Parker \& Haswell 1940, p. 353 ; Curtis \& Guthrie 1927, p. 220 ; Guyer 1941, p. 332).

Perfilham, portanto, os autores de língua alemã a verdadeira opinião de Heath, quando registram Graffizoon lobatum como espécie neotênica. São êstes Meixner (1. c. ; 1938, p. 105), Bock (l. c.) e Bresslau (1933, p. 165, 292). Também Stummer-Traunfels (1933, p. 3587) apresenta G. lobatum como o menor Policladido, i. é, como animal adulto e acrescenta outros casos de neotenia.

Se a opinião das autoridades citadas fosse adotada por todos, a família Graffizoidæ Heath deveria ser re-estabelecida, pois a diferença entre Graffizoon lobatum e as Euryleptidæ é muito maior que a entre estas e as Laidlawiidæ. Mas, a neotenia do verme não está provada. Animais neotênicos combinam crescimento especificamente completo e, frequentemente, nem sempre (girinos gigantes), maturidade sexual com traços larvais (brânquias, dentes e nadadeira de Ambystoma) ou juvenis (dentes lácteos em Mamífero adulto). Não se sabe, se Graffizoon alcança, na forma conhecida, o seu tamanho definitivo. Heath (1928, p. 202), é verdade, manteve alguns exemplares de proporções médias durante quasi um mês, sem conseguir desenvolvimento ulterior. $\mathrm{O}$ autor admite que faltou alimento adequado.

A pequenez de Graffizoon lobatum dificulta, mas não impossibilita, considerá-lo como adulto. O Policladido maduro e não larval, de tamanho mínimo (1 mm.), Acerotisa notulata (Bosc; Hyman 1939, p. 21) pertence às Euryleptidæ. A espécie vive entre Sargassum pelagial. Ao descrever outra espécie de Acerotisa disse Lang (1884, p. 590) : "Quero chamar esta espécie uma forma juvenil das Euryleptidæ que se tornou sexualmente madura" Stummer-Traunfels (1933, p. 3587) salientou a pequenez de vários Policladidos planctônieos, pertencentes a diversas famílias (Palombi 1924). As pequenas espécies de Acerotisa e da coleção da "Liguria" poderiam ser entendidas como neotênicas.

Graffizoon, porém, não parece ser adulto, apesar dos órgãos reprodutivos. O animal possue um "proboscis fundament" (Heath 1928, p. 192) ou "supposed", outra vez, "possible proboscis rudiment" (ibid., p. 204, na explicação das figuras 6 e 8). Se Heath tivesse usado os termos "primordial" ou "Anlage" os autores de língua alemã acima citados possivelmente não teriam falado em Policladido neotênico. Talvez não tenham encontrado "fundament" no texto, mas duas vezes "rudiment" na explicação das figuras. "Rudimentum" significa o primeiro início, mas tornou-se, na zoologia alemã, primeiramente um órgão que não se desenvolve além do primeiro esbôço e, depois, um órgão em involução, em regresso, um resto. Somente StummerTraunfels denomina o primórdio univocamente "Anlage des definitiven Pharynx" (1933, p. 3588, na explicação da figura 170).

Naturalmente é admissível imaginar que Graffizoon lobatum morre, depois da produção de células germinativas, com um primórdio de uma faringe 
de um Policladido adulto. Mais provável, porém, parece que continua a desenvolver-se. O primórdio de uma faringe definitiva insinua o alcance de uma fase definitiva, por meio da metamorfose típica das larvas de Müller. Além disso, encontrámos a larva de Cycloporus gabriellæ, das Euryleptidæ, com órgãos reprodutivos. Esta larva insere-se facilmente entre as larvas estéreis e o verme recem-metamorfoseado, igualmente estéril, da mesma espécie. Por isso, consideramos também Graffizoon lobatum como verme progenético. A progênese é a reprodução de um animal que ainda não alcançou a sua forma ou o seu tamanho definitivos (Meisenheimer 1921, p. 711). Progênese é sinônimo de pedogênese, no sentido original desta. A espécie definitiva de Graffizoon lobatum deveria ser procurada entre as várias Euryleptidæ da baía de Monterey. Não duvidamos que será encontrada e, com isso, estabelecido mais um caso do raro fenômeno da dissogonia.

\section{Família : Prosthiostomidæe Lang (1884, p. 594)}

\section{Genus : Prosthiostomum Quatrefages (1845, p. 132)}

Prosthiostomum matarazzoi, spec. nov. (Figs. 167-171, 181)

A espécie baseia-se em várias dezenas de animais, cujo comprimento atinge $20 \mathrm{~mm}$., no estado vivente. A tabela seguinte indica as medidas (em milímetros) e outros constantes de quatro exemplares conservados, os dois menores imaturos, os dois maiores maduros.

\begin{tabular}{|c|c|c|c|c|}
\hline $\begin{array}{lllll}\text { Comprimento : } & \ldots & \ldots & \ldots & \ldots\end{array}$ & 1,22 & 4,0 & 7,5 & 8,0 \\
\hline Largura : . . . $\quad \ldots$ & 0,4 & 1,2 & 1,8 & 2,2 \\
\hline Distância da bôca ao bordo anterior:. & 0,36 & 0,63 & 1,05 & 1,2 \\
\hline Distância da raíz da faringe ao bordo anterior : & 0,76 & 1,83 & 2,85 & 3,4 \\
\hline Distância da ventosa ao bordo anterior :. & 0,9 & 2,08 & 3,8 & 4,4 \\
\hline Comprimento da faringe: & 0,4 & 1,2 & 1,8 & 2,2 \\
\hline Comprimento do cérebro: $\quad \ldots \quad \ldots$ & 0,125 & 0,15 & 0,185 & 0,185 \\
\hline Largura do cérebro: $\quad \ldots \quad \ldots \quad \quad \ldots$ & 0,15 & 0,2 & 0,24 & 0,24 \\
\hline Olhos cerebrais, de cada lado; número: & 2 & 7 & 12 & 18 \\
\hline Número dos olhos marginais : & 6 & 26 & 57 & 83 \\
\hline Comprimento da ventosa : . . . & 0,04 & 0,175 & 0,22 & 0,25 \\
\hline Distância da raíz da faringe à ventosa : & 0,14 & 0,25 & 0,95 & 1,0 \\
\hline
\end{tabular}

O corpo é anteriormente arredondado, posteriormente cuspidato (Fig. 171). O dorso é cinzento-esverdeado claro, com certa variação da claridade. A tabela orienta sôbre a posição da bôca, que se encontra imediatamente atrás do cérebro (c) ; a faringe (f) é reta e anteriormente um pouco alargada. A distância entre a ventosa e a extremidade posterior aumenta com o crescimento do corpo, sendo êste especialmente intenso na metade caudal. $\mathrm{O}$. 
desenvolvimento do complexo copulatório condiciona a distância crescente entre a raiz da faringe e a ventosa (Fig. 181 e 171). Esta é mais comprida que larga.

Em todos os vermes ocorrem dois olhos ventrais (Fig. 167, y), de diâmetro de 24 micra, frequentes nos Cotylea. Os olhos cerebrais, cujo número foi indicado na tabela, acusam tamanho diferente ; os maiores são de 40 micra. Os olhos marginais (z) são menores, no máximo, de 27 micra. São todos dirigidos para fora, e os maiores distam mais que os menores do sulco sensorial (sr) periférico. Nos vermes maduros quasi desaparece a interrupção ântero-mediana dos olhos marginais que ocorre nos imaturos, estendendo-se os olhos também lateralmente mais para trás, nos adultos. O nivel dos últimos olhos marginais é aproximadamente o mesmo como o do bordo posterior do cérebro.

A epiderme do dorso é duas vêzes tão alta quão a ventral. Além disso, desaparecem os cílios dorsais à altura do cérebro. Rabditos e células vazias são dorsalmente muito mais numerosos que no ventre, onde os cílios são contínuos. Também a membrana basilar é dorsalmente mais forte que no ventre, mas a musculatura cutânea ventral é mais desenvolvida que a dorsal. $\mathrm{O}$ revestimento da ventosa (Fig. 169, k) apresenta duas zonas diferentes, a periférica e a central. A primeira é formada por células altas e esbeltas que conteem feixes de rabditos, raros na epiderme ventral restante. As células centrais são mais altas ainda e isentas de rabditos. Os núcleos são aí alongados e situados basilarmente. As porções apicais destas células centrais da ventosa são repletas de secreção, disposta, em cada célula, como uma cadeia de pérolas. As glândulas que fornecem a secreção da ventosa são aprofundadas no parênquima. Como em outros Turbelários (Mesostoma ehrenbergii ; observação de vermes jovens nos ovos subitâneos), é o cérebro dos animais imaturos relativamente muito maior que nos adultos.

A bôca apresenta-se como orifício de um tubo bucal, seguido pela bolsa faríngea (b). Esta envolve a faringe (f) estreitamente. A grossura da faringe produz uma entumescência do corpo do verme, apesar da supressão do parênquima nesta região, em que o integumento e os músculos cutâneos circundam apertadamente a bolsa faríngea. No meio da faringe acusa a altura do corpo (direção dorso-ventral) $0,7 \mathrm{~mm}$. ; nos dois lados da faringe, $0,5 \mathrm{~mm}$.. O epitélio da bolsa é baixo e nucleado ; os músculos anelares e longitudinais são fortes. Na região anterior da bolsa e até além da metade, sobrepõe-se a musculatura anelar à longitudinal ; na parte posterior, a longitudinal à anelar. Em Euprosthiostomum mortenseni Marcus (1948, p. 185) são os músculos da bolsa inversamente dispostos. O epitélio externo da faringe tem núcleos ; o interno, não. Ambos são sem cílios. As glândulas são cianófilas e desembocam, na sua maioria, ao redor da boca faríngea, ampla e campaniforme. Algumas glândulas pequenas abrem-se também na face externa, i. é, no estreito espaço entre faringe e bolsa faríngea.

$\mathrm{O}$ intestino principal (i) caracteriza-se pelas clavas de Minot abundantes (mi). Estas já ocorrem no diafragma (h) tubiforme e mole, de comprimento de $0,4 \mathrm{~mm}$. que se projeta na faringe. Caudalmente à ventosa, rareiam as clavas e faltam no intestino terminal (j), que contém fezes.

Os divertículos intestinais são ciliados e providos dos músculos anelares que condicionam o aspecto moniliforme típico dêles. Não se anastomosam e são escassos na região anterior, ao lado da faringe. Mais para diante, 
dirigem-se dois divertículos, um de cada lado da faringe, que se reunem na cabeça.

Os folículos germinativos masculinos e femininos começam pré-cerebralmente e aproximados ao lado ventral. Os ovócitos em crescimento estendem-se daí em direção dorsal. Os dutos eferentes (Fig. 168, d) vindos de trás, onde são ligados, entram na vesícula seminal (s) pela parede anterior desta. Também o duto ejaculatório (e) sae pela calota anterior da vesícula seminal. Os músculos desta tocam-se com os das vesículas accessórias (Fig. $169, \mathrm{r})$, mas não se trata, como em $P$. drygalskii Bock, de um envoltório comum dos três órgãos. Os músculos das duas vesículas, situadas uma dorsalmente ao duto ejaculatório, a outra ventralmente, são reunidos em forma de 8. Outras espécies com vesículas accessórias circundadas por músculos unidos são $P$. purum Kato, $P$. delicatum Pal., $P$. russoi Pal. e $P$ gabriellæe Marc.. O duto ejaculatório atravessa a musculatura das vesículas e entra na papila penial bulbiforme. Esta encontra-se dentro da bolsa do penis (l) e termina com estilete cuticular (p). O comprimento dêste (Fig. 170) é de $0,18 \mathrm{~mm}$. ; a largura de $0,06 \mathrm{~mm}$., na base e de $0,015 \mathrm{~mm}$. na ponta. A base é ligeiramente sulcada. Os dois dutos finos das vesículas accessórias desembocam na base da papila penial. O estilete atravessa a vesícula da secreção granulosa (q), abrindo-se juntamente com esta no átrio masculino (a). O átrio é uma bolsa larga, aberta (t) para trás.

Os ovidutos ciliados desembocam nos úteros (x), caudalmente ligados e situados dorsalmente aos dutos eferentes (d). Caudalmente à vesícula seminal (s) reunem-se os dutos uterinos, constituindo o duto uterino comum (w), que se dirige verticalmente para a face ventral. Como nas outras espécies do gênero ocorrem dois trechos diferentes da via eferente feminina, a bolsa das glândulas argamassadoras (v), no centro das glândulas correspondentes, bem numerosas (g), e o trecho ectal, o canal genital feminino que se abre com o poro feminino (u). O número haplóide dos cromosomas é 4 .

Ocorrência : Ilha de São Sebastião, entre algas calcáreas (Jania rubens L.) do Litoral superior. Numerosos espécimes, em março de 1948, em abril de 1949 e, especialmente, em novembro de 1949.

Ao nosso estimado Amigo, Sr. Cmdr. Paulo Matarazzo dedicamos, profundamente gratos, a nova espécie.

\section{Discussão de Prosthiostomum matarazzoi}

$\mathrm{Na}$ separação da espécie atual das outras do gênero sirvo-me da lista há pouco compilada (Marcus 1949, p. 89) sem, porém, repetir a literatura aí indicada.

1) sparsum (Stimps.). Espécie muito larga, pois a largura atinge a metade do comprimento.

2) obscurum (Stimps.). Dorso acastanhado-vermelho, com manchas avermelhadas e listra mediana, mais clara.

3). grande Stimps. Apenas 25 olhos marginais que terminam muito antes do nível anterior dos olhos cerebrais.

4) constipatum Stimps. A diagnose não permite definir os caracteres específicos.

5) cribrarium Stimps. Tem poucos olhos marginais.

6) crassiusculum Stimps. A largura corresponde a pouco menos que a metade do comprimento. A posição genérica não está assegurada.

7) tenebrosum Stimps. O dorso é cinzento escuro até negrejante.

8) monosorum (Schmarda). A faringe dispõe-se com 7-8 alças na bolsa faríngea. 
9) macrorhynchum (Schmarda). Os olhos cerebrais formam dois grupos triangulares.

10) siphunculus (Delle Chiaje). As vesículas accessórias são separadas uma da outra.

11) dohrni Lang. Os olhos cerebrais são muito numerosos, de tamanho uniforme e dispostos em dois grupos que convergem para diante.

12) nationale Plehn. Com faixa longitudinal-mediana de côr acastanhada-escura, no dorso claro.

13) cyclops (Verr.). A faringe tem quasi metade do comprimento do corpo ; as vesículas accessórias são afastadas uma da outra ; o átrio masculino é uma bolsa muito comprida.

14) elegans Laidl. O dorso é de côr amarela-pálida com duas séries de cromatóforos, côr de chocolate, de cada lado da linha mediana.

15) cooperi Laidl. Os olhos marginais estendem-se, para trás, muito além dos olhos cerebrais e do cérebro.

16) pallidum Laidl. Os dois grupos dos olhos cerebrais divergem continuamente, de diante para trás.

17) singulare Laidlaw (1904, p. 135). Sem olhos cerebrais.

18) lineatum Meixner. Entre os olhos cerebrais e marginais ocorre um grupo de olhos frontais.

19) maculatum Hasw. De cada lado existem 50 olhos cerebrais; os olhos marginais acabam antes do nivel dos cerebrais.

20) angustum Bock. Muito mais estreito que a espécie atual, pois o comprimento é de $19 \mathrm{~mm}$.; a largura, de $2,5 \mathrm{~mm}$.

21) pulchrum Bock. A ventosa situa-se longamente atrás do meio do corpo.

22) marmoratum Yeri \& Kaburaki. Os olhos marginais terminam muito antes do nível dos cerebrais.

23) awaense Yeri \& Kaburaki. Entre os olhos cerebrais e marginais há olhos frontais.

24) rubropunctatum Yeri \& Kaburaki. Dois grupos compactos de olhos cerebrais que convergem para diante.

25) trilineatum Yeri \& Kaburaki. De côr láctea com duas estrias dorsais longitudinais, pretas, e uma marca transversal amarela-preta, na cabeça.

26) molle Freeman. A ventosa situa-se no início do último quarto do corpo.

27) capense Bock. A ventosa localiza-se no início do quarto quinto do corpo.

28) drygalskii Bock. A vesícula seminal e as duas vesículas accessórias são circundadas por um manto comum de músculos.

29) asiaticum Kato. As vesículas accessórias são pequenas e muito distantes uma da outra.

30) auratum Kato. De cado lado, há 7 olhos cerebrais ; o número total dos olhos marginais é aproximadamente 12 .

31) ostreæ Kato. O corpo é muito estreito, sendo o comprimento de $26 \mathrm{~mm}$. ; a largura, de $2 \mathrm{~mm}$.

32) purum Kato. De côr láctea. O comprimento da faringe é de um sexto a um quinto do comprimento do corpo. Complexo copulatório muito distante da faringe.

33) yerii Kato. De côr láctea com estria mediana acastanhada-avermelhada. Os dois grupos dos olhos cerebrais divergem para trás.

34) vulgare Kato. Os olhos marginais acabam antes do nível anterior do cérebro.

35) sonorum Kato. Os olhos marginais não atingem o nivel anterior do cérebro.

36) lætum Kato. Os dois grupos dos olhos cerebrais convergem para diante, formando, em comum, um triângulo.

37) lobatum Pearse. A faringe é muito comprida. Os olhos marginais ultrapassam o nível posterior do cérebro, e os cerebrais estendem-se muito além do bordo anterior do mesmo.

38) parvicelis Hym. Há 7-8 olhos cerebrais, de cada lado.

39) bellum Kato. De côr láctea com manchas acastanhadas. As vesículas accessórias são distantes uma da outra.

40) delicatum Palombi. O dorso é claro, amarelado-esbranquiçado, havendo duas faixas longitudinais, côr de ocre, de cada lado da linha mediana.

41) russoi Palombi. Os dois grupos dos olhos cerebrais convergem para diante. O diâmetro de cada vesícula accessória é inferior ao comprimento do estilete.

42) gabriellæ Marc. Há quatro olhos cerebrais e quatro pré-cerebrais. 


\section{Prosthiostomum gilvum, spec. nov. (Figs. 172-175)}

A forma do corpo assemelha-se à da espécie precedente. Quando viventes, os dois vermes disponíveis atingiram comprimento de $15 \mathrm{~mm}$.. Depois da conservação, a longura é de $10 \mathrm{~mm}$. ; a largura máxima, de $3,5 \mathrm{~mm}$.. Nêste estado, a ventosa (k) encontra-se no início do último terço do corpo (Fig. 172). A côr do dorso é alaranjada clara, sem manchas ou listras. A bôca (b) aproxima-se ao cérebro (c); o comprimento da faringe (f) dos vermes conservados é de $4,4 \mathrm{~mm}$. ; a forma da mesma corresponde à de $P$. matarazzoi.

Além dos olhos ventrais (y), de diâmetro de $0,028 \mathrm{~mm}$., ocorrem olhos cerebrais (Fig. 173, c) e marginais (z). Os cerebrais formam dois grupos paralelos, de 37-46 olhos cada um, de que se estendem, da região post-cerebral, quasi até aos olhos marginais. Ultrapassam, com isso, o nível dos olhos ventrais, para diante. Os olhos cerebrais são, em geral, pequenos ; o diâmetro dos maiores entre êles é de $0,034 \mathrm{~mm}$. . Os olhos marginais são numerosos (150-165) e também pequenos, sendo o diâmetro dos maiores de 0,022 mm.. Formam uma faixa larga contínua, sem qualquer interrupção ânteromediana, e estendem-se, para trás, até ao nível do cérebro.

A altura da epiderme dorsal ultrapassa, como na espécie precedente, a da ventral. São também numerosos, no dorso, os rabditos e as células glandulares, de secreção colorífica (Stummer-Traunfels 1933, p. 3590) e vazias nos cortes. A grossura da membrana basilar é de 5 microns, no dorso. A musculatura cutânea do ventre é mais forte que a do dorso. A histologia da ventosa (Fig. 174, k) corresponde à descrita de $P$. matarazzoi, o diâmetro da mesma é de $0,25 \mathrm{~mm}$.. Um dos dois exemplares presentes possue duas ventosas, uma atrás da outra, como o espécime de Thysanozoon brocchii Grube da figura 10 da estampa 1 de Stummer-Traunfels 1933 (explicação na página 3566).

Como em $P$. matarazzoi e também em P. gabriellæ Marcus (1949, p. 88), faltam em $P$ gilvum os grupos de células ganglionares, pré-cerebrais ("äussere Körnerhaufen").

Numerosas células claviformes de Minot (Fig. 174, m) situam-se no intestino principal e na parede dorsal do divertículos, que são ciliados e providos de constrictores successivos. As preparações totais mostram a mesma acumulação das fezes no intestino terminal (j) como em P. matarazzoi. No intestino de um dos vermes presentes encontram-se um exemplar de Acerotisa bituna Marcus (1947, p. 138) e a faringe de um Prosthiostomum. Observámos os indivíduos de Prosthiostomum apalparem-se mutuamente, por meio da faringe evaginada. Entende-se que, nesta ocasião, um verme pode arrancar a faringe do outro.

Os folículos das gônadas começam antes do cérebro. Da posição original, que é ventral para testículos e ovários, os ovócitos crescem para a região dorsal. Os dois dutos eferentes (Fig. 172, d) são reunidos na parte caudal do corpo e correm daí, dilatados pelos espermatozóides, para diante. Entram no meio da vesícula seminal (Fig. 175, s) pelas paredes direita e esquerda desta. A vesícula é oblonga e estreita. O duto ejaculatório (e) sáí do polo anterior da vesícula seminal. Depois de um percurso meândrico, recebe, na base da papila penial, os dois dutos sinuosos das vesículas acces- 
sórias (r). Estas são separadas, possuindo cada uma a sua musculatura própria. A bolsa do penis (l) é extremamente incospícua. A pequena papila do penis (âncora do estilete, Hyman 1939b, p. 7) apresenta-se obliqua, pois o seu lado dorsal é mais comprido que o ventral. O estilete (p), de 0,22 mm., ao comprido, atravessa a vesícula granulorum (q) e abre-se na cúpola de uma saliência projetada para o lume do átrio (a). Este é musculoso, muito comprido e de parede dobrada. O epitélio desta e o lume atrial conteem secreção eritrófila, bacilar, que lembra rabditos. A secreção é produzida pelo epitélio atrial.

As vias eferentes femininas concordam, por princípio, com as de $P$ matarazzoi. Os úteros $(\mathrm{x})$ situam-se dorsalmente aos dutos eferentes e reunem-se caudalmente à vesícula seminal. O duto uterino comum (w) dirige-se para o lado ventral. A bolsa (v) das numerosas glândulas argamassadoras (g) é seguida pelo canal genital feminino (n). A distância entre o orifício externo do átrio masculino $(\mathrm{t})$ e o poro feminino $(\mathrm{u})$ é de $0,205 \mathrm{~mm}$.; a entre o último e a ventosa, de $0,32 \mathrm{~mm}$..

Ocorrência: Ilha de São Sebastião, entre algas do litoral superior ; dois exemplares maduros em novembro de 1949.

\section{Discussão de Prosthiostomum gilvum}

As espécies ns. 1-3, (4), 5-9, 12, 14-18, 20, 22-25, 28, 30-36, 38, 40, 42 (veja p. 96) distinguem-se de $P$ gilvum pelos caracteres precedentemente mencionados. As espécies seguintes precisam de um rapido comentário :

10) siphunculus (Delle Chiaje). O número dos olhos marginais e o dos cerebrais é menor que na espécie presente.

11) dohrni Lang. De côr clara com manchas mais escuras ; os olhos marginais estendem-se, para trás, além do nível do bordo posterior do cérebro.

13) cyclops (Verr.). Manchas acastanhadas sobrepõem-se ao fundo branco; a faringe é muito comprida.

19) maculatum Hasw. Difere de $P$ gilvum pela côr e pelo número menor de olhos marginais que acabam antes do nível dos cerebrais.

21) pulchrum Bock. Os olhos marginais são pouco numerosos.

26) molle Freeman. Os olhos marginais atingem o nivel do meio da faringe.

27) capense Bock. O número dos olhos marginais (ca. de 40) é muito menor que em $P$. gilvum.

29) asiaticum Kato. Tem manchas acastanhadas, e os olhos cerebrais não se estendem, para diante, além do nível anterior do cérebro.

37) lobatum Pearse. A faringe desta espécie é muito comprida.

39) bellum Kato. De côr láctea, com manchas acastanhadas.

41) russoi Palombi. A musculatura reune as duas vesículas accessórias.

43) matarazzoi (Figs. 167-171). Tem outra côr, olhos maiores e em menor número, e vesículas accessórias reunidas pela túnica muscularis.

\section{Prosthiostomum cynarium, spec. nov. (Figs. 176-180)}

O corpo é anteriormente arrendondado; posteriormente, cuspidato. A sua forma geral varia, se.ldo alguns exemplares mais curtos e largos (comprimento : 4,6 mm. ; largura : 1,4 mm.) ; outros, mais longos e estreitos (comprimento : $5 \mathrm{~mm}$. ; largura : $1 \mathrm{~mm}$.). A ventosa (Fig. 177, k) ocupa, aproximadamente, o meio do corpo ou situa-se um pouco atrás dêste. A 
côr é clara, ora mais de marfim, ora mais acinzentada. Desenhos ou manchas não ocorrem. O cérebro (c) esta perto da bôca (b), como nas outras espécies do gênero. A faringe (f) é ligeiramente espessada para diante e de 0,98-1,4 mm., ao comprido.

$\mathrm{O}$ diâmetro dos olhos ventrais (y) é de $0,013 \mathrm{~mm}$. Os olhos cerebrais não ultrapassam o cérebro (c) para trás e muito pouco para diante. Cada um dos dois grupos forma uma série em zigue-zague, havendo em um dos vermes (Fig. 178) 4 e 5, em outro 8 e 10 olhos por grupo. Os exemplares restantes acusam números intermediários (Fig. 179). O diâmetro máximo do: olhos cerebrais é de $0,026 \mathrm{~mm}$. Os olhos marginais (z) atingem, maximamente, o nível do bordo posterior do cérebro. No meio do bordo anterior do corpo reconhece-se ligeira separação dos grupos direito e esquerdo. Estes compõem-se de 5 e 7 olhos, em um dos maiores vermes do nosso material (Fig. 178) ; em outro espécime, há 14 e 15 olhos marginais. O diâmetro máximo dêles é de $0,023 \mathrm{~mm}$.

A epiderme do dorso é três vezes mais alta que a ventral e contém mais rabditos e glândulas que esta. A musculatura cutânea ventral é mais forte que a dorsal. O diâmetro da ventosa é de 0,09 mm., no estado invaginado (Fig. 180,k) ; em um dos animais aquí em mãos (Fig. 176) é evertida e forma, nesta fase, uma placa de diâmetro de $0,35 \mathrm{~mm}$. Os gânglios pré-cerebrais são muito reduzidos, pois ocorrem apenas 3-4 células ganglionares, de cada lado. Células claviformes de Minot (m) existem no intestino principal (i), que contém, em um dos vermes presentes, um exemplar de Alcha evelinæ.

Os folículos das gônadas começam ao nível do meio da faringe. Os testículos são mais ventrais e situados mais lateralmente que os ovários, que se originam à meia altura entre ventre e dorso. Os dutos eferentes (Fig. 177, d) não são ligados na região posterior do corpo, onde começam a dilatar-se. Correm sinuosamente para diante e entram separadamente na esférica vesícula seminal (s) através das paredes ântero-laterais desta. O duto ejaculatório (Fig. 176,e) sái anteriormente da vesícula seminal e entra na papila do penis, que se dirige quasi dorsalmente. Na raiz da papila, o duto recebe os curtos dutos das vesículas accessórias (r), que são completamente separadas. A papila constitue a base do estilete penial (p) que é encurvado. O estilete atravessa a bolsa do penis (l), a vesícula granulorum (q), e ainda penetra um pouco no lume do átrio (a). A vesícula granulorum é separada do átrio comprido e largo pela bainha do penis.

Os úteros (Fig. 177,x) compõem-se de dois braços anteriores e dois posteriores. Os primeiros começam atrás da raiz da faringe e atingem o nível do poro feminino (u). Daí estendem-se os dois braços posteriores até ao nível do meio entre o poro feminino e a extremidade caudal do corpo. Onde os braços posteriores terminam, são ligados por uma comunicação transversal como em $P$ matarazzoi. O duto uterino comum (w) origina-se no ponto da reunião dos úteros anteriores e posteriores ; os trechos seguintes da via eferente feminina, a bolsa (v) das glândulas argamassadoras (g) e o canal genital feminino, correspondem às mesmas estruturas das outras espécies do gênero Prosthiostomum.

Ocorrência : Ilha de São Sebastião, entre algas do litoral superior. Obtivemos, em novembro de 1949, oito exemplares, dos quais 1 completamente maduro, 2 quasi maduros, 3 em fase masculina jovem e 2 imaturos. 


\section{Discussão de Prosthiostomum cynarium}

Usando os números da lista precedente (p. 96) e acrescentando os $\mathrm{n}^{\circ}$ s. 43 e 44 para $P$. matarazzoi e $P$. gilvum, respectivamente, separamos $P$. cynarium da maneira seguinte : as espécies 1-2, (4), 7-9 11, 15-18, 21, 23-28, 31, 33, 36-37, 42 distinguem-se, de $P$. cynarium, pelos caracteres indicados na lista aludida.

3) Os olhos cerebrais formam campos alongados, concentrados.

5) Os olhos cerebrais são muito numerosos.

6) O corpo é mais largo ; os olhos marginais ultrapassam, para trás, o nível dos numerosos olhos cerebrais.

10) Os grupos dos olhos cerebrais são retilíneos; os olhos ventrais não saem fora do nível dos cerebrais.

12) Os olhos cerebrais formam dois grupos alongados que convergem para diante.

13) A faringe tem quasi metade do comprimento do corpo.

14) Os olhos cerebrais formam um nítido $V$, cujo ápice se dirige para diante.

19) Cada grupo de olhos cerebrais abrange ca. de 50 olhos, no animal maduro.

20) Os olhos marginais ultrapassam, para trás, longamente os cerebrais.

22) Os olhos marginais terminam muito antes do nível dos cerebrais ; êstes dispõem-se em dois grupos ovais, de contornos bem definidos.

29) Os olhos marginais estendem-se além do nível do cérebro, para trás.

30) O comprimento do corpo é 8 vêzes maior que a largura. Os olhos cerebrais formam duas séries, de 7 olhos cada uma.

32) O comprimento do corpo é $15-20$ vêzes maior que a largura.

34) Os grupos dos olhos cerebrais são quasi retilíneos.

35) De côr branca, com manchas acastanhadas que formam uma listra no meio do dorso.

38) Ventosa na metade caudal do corpo.

39) Os numerosos olhos marginais estendem-se, para trás, além do nível do cérebro.

40) Ventosa no início do último terço do corpo.

41) As duas vesículas accessórias são reunidas pela musculatura.

43) As duas vesículas accessórias possuem manto musculoso comum.

44) A ventosa situa-se no início do último terço do corpo.

\section{Summary}

Haploposthia microphoca, n. sp. (Fig. 1-2) was found between algae in the upper littoral of the island of São Sebastião, while the other species of the genus are benthonic or live in the sand. The seal-like shape of the body and the eyes (Fig. 1) are adaptations of the present species to its biotope. $H$. microphoca belongs to the species with diffuse male and female germ-zones ; they lie on both sides of the body (o). It differs from $H$. brunea by . the strongly developed frontal glands (g) and from $H$. rubra by the small number of rhabditogenous ( $r$ ) glands (colour : golden yellow) and the absence of a cuticularized male organ. The seminal vesicle ( $\mathrm{s}$ ) is as in H. viridis.

Paraproporus xanthus, n. sp. (Fig. 3-5), from mud in about $5 \mathrm{~m}$. depth on the coast of the island of São Sebastião, differs from $P$. rubescens Westbl. principally by yellowish pigment granules, concentrated (f) frontal glands (frontal organ present) and small ovocytes (up to $0,05 \mathrm{~mm}$. in diameter). These (o) are surrounded by flat follicle-cells. In tangential sections (Fig. 4) the epicytium shows the cell-territories. The dorso-ventral muscles (k) are more developed than in rubescens, and the ectocytium is distinct also in 
the posterior region of the body (Fig. 5,h). From the same locality several pink-violet specimens without frontal organ and with big ovocytes were obtained, the epicytium of which shows the same structure as in $P$. xanthus. It is probable, but not yet certain, that these purple worms belong to $P$. rubescens.

Childia pansa, n. sp. (Fig. 8-9), from mud in the channel of Bertioga, near Santos, where tides and salinity shift four times in 24 hours, is closely related to the only other species of the genus, Ch. groenlandica (Lev.). Notwithstanding pansa must be separated, because it has no frontal organ - not even isolated frontal glands were seen - the cutaneous glands (g) are very scarce and the germ-zones (o) of the ovaries lie at the level of the mouth (b) that is a little behind the middle of the body.

Kuma, a new genus of the Haploposthiidæ, with the type $K$. brevicauda, n. sp. (Fig. 10-13) in sand with mud from Cananea, southern coast of the State of São Paulo, was found in salinity inferior to that of the open sea. Colour-glands are absent (against Haploposthia); the frontal glands (f) are strongly developed and nearly concentrated (against Afronta); the male antrum is short, bulbous and without penis (against Paranaperus) or cuticular rods (against Paraproporus). Childia has two penes. The living adult worms of $K$. brevicauda are $0,35 \mathrm{~mm}$. long. The nuclei of the epicytium (Fig. 13,w) in the pre-oral part of the body are depressed. The cutaneous muscles $(\mathrm{m}, \mathrm{y})$ are disposed as in most Acoela; the parenchymatic muscles (h) are well developed. Mucous glands $(\mathrm{u})$ are scarce; rhabdites absent. The ectocytium is narrow (k), but with many nuclei. The endocytium (i) has peripherical nuclei and is vacuolized, specially in the caudal region, where it leaves a big vacuole (j). It contains Diatoms and Ciliates. The mouth (b) lies a little before the middle and has strong divaricators (g). The ovaries (o) are anterior to the testes ( $\mathrm{t}$ ). The cells of the atrial walls (a) are high.

Mecynostomum tenuissimum (Westbl.) (Fig. 14-15) occurs in gray mud in about $5 \mathrm{~m}$. depth on the coast of the island of São Sebastião. The present specimens show some minor differences from the northern ones: the frontal glands (f) are a little more developed, scarce cutaneous glands (g) are present, the posterior retractors were not seen, but dorso-ventral muscles (h) in the same region. The bursa seminalis is absent, and not even masses of sperms were found behind the ovaries. Big cells $(\mathrm{x})$ in the caudal ectocytium may be glandular and perhaps produce the secretion by which the animals stick to mud-particles. The nuclei (n) of the epicytium are depressed in the pre-oral region of the body.

Paraphanostoma westbladi, n. sp. (Fig. 16-18), 1,5 mm. long alive, was found between algæ of the Ilha das Palmas (bay of Santos) and in the same biotope as well as in gray mud (about $5 \mathrm{~m}$. depth) of the island of São Sebastião. It belongs to the species with musculous seminal vesicle (macroposthium, brachyposthium) and with a spermatic duct (z). The male copulatory organ of westbladi is, even in details, identical with that of macroposthium, though it is a little smaller. Notwithstanding westbladi must be separated from macroposthium, as its bursa $(\mathrm{u})$ has neither a posterior pouch nor cuticular hooks. Moreover westbladi is cytologically exceptional by its big nuclei (average diameter 8 micra; in the spermatogonia 10-12 micra) 
that are scarce in all tissues. This character does neither occur in brachyposthium, a species two times or more bigger than westbladi, with the female pore between mouth and male opening (in westbladi and macroposthium it is nearer to the mouth) and small eggs. The longitudinal and transverse parenchymatic muscles of brachyposthium are absent in westbladi. The brain of the new species differs greatly from that described for $P$ submaculatum and crassum, where the ganglion lies behind the statocyst and has two horns directed forward and upward. In $P$. westbladi the statocyst lies behind the commissure of the internal or dorsal ganglia and on the level of this commissure. The commissure of the external or ventral ganglia is caudal and ventral to the statocyst.

Follicle-cells (i) surround even the largest ovocytes (length : $0,1 \mathrm{~mm}$. ; height : $1,6 \mathrm{~mm}$.) of our material ; there are 3-4 nucleoli in the ovocytes as in macroposthium and brachyposthium. The female antrum (w) is globose and of spongeous, vacuolized structure. The spermatic duct (z) inserts at the level of the constriction between antrum and bursa $(\mathrm{u})$, not exclusively at the front-wall of the bursa (macroposthium, brachyposthium).

Aphanostoma orphinum, n. sp. (Fig. 19-20) from Sargassum stenophyllum grown on rocks in the upper littoral of the island of São Sebastião, is only tentatively classified in the genus Aphanostoma, as defined by Westblad $(1948$, p. 2,57$)$. The vesicles (v) that contain the coloured granules of the olivaceous-brown species lie in the epicytium (h), not in the ectocytium $(\mathrm{j})$, as in diversicolor and virescens. The bursal appendage $(r)$ is not so distinctly marked off from the bursa (q) as in the two other species, and its musculature is only represented by a small sphincter. But as the communication between the bursa and the female germ-cells is more complicated than in Mecynostomum and not provided with a cuticular nozzle as in Convoluta, the species must be classified as Aphastoma or considered as the type of a new genus. The nuclei of the epicytium are intra-epithelial and the cutaneous muscles are typically disposed (not as in Paraphanostoma). The common antrum (a) is tubular; a penis that occurs in the two other species of Aphanostoma is wanting.

Convoluta divæ, n. sp. (Fig. 6-7, 21-23) from coarse sand below the regular low-water line on the coast of the island of São Sebastião belongs to the species without eyes and symbiontic algæ. The blue-green colour comes from the endocytium (i) that contains diatoms. The rhabdites (r) are arranged in rows (Fig. 7). The worms stick to the sand with their caudal glands (d). The frontal organ (f), the oral glands (k) and the glands (g) of the gonopore (z) are cyanophilous. The nuclei of the epicytium (h) are all intra-epithelial. The male copulatory organ (Fig. 23) is similar to that of flavibacillum Jens., a species with eyes and algæ, and lineata (Peebles) that has eyes, pigment-cells, long vagina with a glandular organ like flavibacillum, and no frontal glands. The nuclei of the penis-epithelium (x) are lobed as in other secretory cells. The penis-epithelium produces an erythrophilous secretion (y). The granular secretion (u) is furnished by the ental cells (v) of the seminal vesicle (s). The latter, the sac of the penis in Westblad's terminology, has strong longitudinal muscles (ms), the penis annelar ones $(w)$. The short vagina (q) is ciliated, opens into the antrum (a) and is well marked off from the bursa $(\mathrm{m})$. The wall of the latter is very strong, evidently cuticular. The form of the nozzle varies (Fig. 22) according to its 
contraction and dilatation. It must be elastic. The penis and the long nozzle separate $C$. saliens (older terminology) from divx. The penis of norvegica is retracted into the sac, not introverted, and is directed caudally ; the vagina of norvegica is interwoven with plasmatic strands and the bursa indistinctly separated from it.

At the shore of the island of São Sebastião a flattened brown $A m p h i$ scolops (Fig. 24-32) with two caudal lobes and without a statocyst was found among Sargassum stenophyllum growing on stones. The colour is produced by algæ (z) that lie principally in the dorsal ectocytium. After Buchner (1930, p. 134) these algæ generally called zooxanthellæ are not yet classified. Most of the epicytial nuclei (c) are depressed. Rhabdites are absent. The strong fibres of the annular musculature (a) are interspaced. The lateral nerves are united by a pre-cerebral commissure joined to the brain by numerous connectives (Fig. 27). Eyes developed as pigment-spots lie on the level of the brain. They are not preserved in the sections. Luther's sense-organs (s) form a dense row on the anterior and lateral borders.

The testes ( $t$ ) consist of small groups of few big cells ; their position is more ventral than dorsal. The male copulatory organ begins with a vesicle (k) that contains granular secretion ; the present material does not contain any ripe sperms. The long, ciliated male antrum (am) has a strong muscular wall and can probably be everted. The vagina (l) is long, thick and muscular, and has a ciliated epithelium with depressed nuclei. The bursa $(y)$ is loose and bilobate. Each lobule has 2-3 nozzles (Fig. 30) that penetrate into a strand (v) of ovarian stroma-cells. These cells begin in the growing zone of each ovary and trend towards the ventral side, where they touch the surface through interruptions of the epicytium (w). If the eggs were laid through these interruptions after having been led to them by the strands, the species would be the first Acoel with efferent female organs.

Although Miss Hyman's description of $A$. sargassi does not include the sex organs, the determination of the present species as $A$. sargassi is supported by the absence of a statocyst (only one other case known : A. evelinæ), the colour, the caudal lobes, the size and shape of the body, and the occurrence on Sargassum.

An ample material of Microstomum gabriellæ, n. sp. (Fig. 33-38) was obtained at the island of São Sebastião in the zone of mean low tides, where the worms live among algæ, chiefly Sargassum stenophyllum. In april and june 1949 they were all dividing and without sexual organs. The adhesive gland-cells (h) correspond to Wagner's description (1891), not to Hofsten's (1907). The epidermis has depressed nuclei in the ciliated pits and the anterior region of the body (Fig. 34, 37, v) and normal ones in the rest (x). The pharyngeal nerve-ring is closed as in Graff's figure (1904-08, f. 36 on p. 2167), not open in front (Kepner \& Taliaferro 1912). The nerves that join the ring to the brain (Luther 1904, p. 76, note 1) are the ventro-lateral nerves of Kepner \& Taliaferro.

Graff (1913) records 9 marine species (listed on p. 24). Of these only $M$. groenlandicum (Lev.) combines rhabdites all over the body with a photo-receptor, but the latter is a single median eye. Moreover the intestine of rgoenlandicum is provided with lateral, lobulated diverticles. Of the 5 marine species described since 1913, only dermophthalmum and melan- 
ophthalmum have eyes. In the first species these eyes are epithelial pits (in gabriellæ pigment-spots) ; in the second they are black with a refractive cell that functions as a lens (red eyes without a lens in gabriellæ).

Microstonum trichotum, n. sp. (Fig. 39-41) from Corallinaceæ near the low-water line of the island of São Sebastião has very shallow, almost invisible ciliated pits and no eyes. There is a pair of anterior unicellular knobs (a) that contain dark granules which somewhat liken the eyes of Alaurina (Brinkmann 1905, t. 2 f. 10, 17). The knobs are supplied with nerves. Also the conical anterior region resembles the proboscis of $A$. alba that is ciliated, contrary to $A$. composita and $A$. prolifera. But the present species has adhesive papillæ $(\mathrm{k})$ only on the tail and no tracts of rhamnites. The rabdites of $M$. trichotum are united in thick, pyriform groups, 0,022 $\mathrm{mm}$. long in sections. Stenostomum sieboldii Gr. that belongs to the Microstomidæ has similar rhabdites, but its anterior end is broadly rounded, the ciliated pits are deep and the glands of the pharynx open near the entrance of the intestine. The nuclei of the pharynx (f) of $M$. trichotum are depressed. The unpaired compact testis ( $\mathrm{t}$ ) arises from 3 separate groups of cells in the fission-zone. None of the known species of Microstomum is closely related to the present one; perhaps $M$. lucidum is the least distant, but it has different rhabdites and anterior region. Besides the chains of 4 zooids of lucidum are 1,5 mm. long; those of trichotum composed of 3 zooids measure only $0,5 \mathrm{~mm}$. alive.

'The difficulty to separate the present species from Alaurina alba shows that Alaurina should perhaps be restricted to composita and prolifera. If as Brinkmann supposed these two are identical, the name composita must be dropped.

Microstomum ulum, n. sp. (Fig. 42-48) lives in coarse sand with single tufts of Padina and other algæ, below the regular low-water line on the coast of the island of São Sebastião. Big specimens of Gyratrix hermaphroditus Ehrbg. and Dolichomacrostomum mortenseni are characteristic of the accompanying fauna. Eyes are absent; the ciliated pits (w) are very well developed. The nuclei of the epidermal epithelium are normal. The erythrophilous rhabdites (r), 50 of which are bundled in one cell $(0,025 \mathrm{~mm}$.), are similar to those of $M$. trichotum. Other volumous cells (y) with thick, faintly stained rods are perhaps adhesive, but they resemble those in $M$. gabriellæ (Fig. 35, r) that are considered as rhabditogenous. The nematocysts (s) that occur scarcely are in the integument always lodged in these cells $(y)$. The head-glands (h) open singly. The caudal plate has erythrophilous, depressed adhesive cells $(\mathrm{k})$.

The brain (c) has a distinct capsule. At the entrance of the ciliated pits (w), where the postero-lateral nerve (n) passes dorsally, a tuft of long cilia belongs to sensory cells $(t)$.

The mouth (b) is round ; the pharyngeal glands (g) are acidophil. Some club-shaped cells of Minot (m) surround the entrance of the intestine (i). The lumen of the latter disappears, when its cells during certain digestive phases form a syncytial mass. The pre-oral intestine (q) is short. As food Hydrozoa, and once an egg-sac (e) of a Copepod, were observed. The present chains are composed of up to 4 zooids; gonads are not developed. The 10 other marine species of Microstomum without eyes show combinations 
of characters that make specific separation of ulum necessary; also Stenostomum sieboldii is different.

Macrostomum evelinæ Marc. previously found in sea-water was collected in sand, in the mouth-region of a swiftly running brook (island of São Sebastião) where the water is completely fresh while the tide goes out and brackish when it comes in.

Dolichomacrostomum mortenseni, n. sp. (Fig. 49-52) lives in coarse sand with algæ below the low-water line on the coast of the island of São Sebastião. It has dermal rhabdites ( $r$ ) as well as cephalic and caudal adenal ones (h) ; the latter function as adhesive organs. Head-glands are absent. The intestine (i) has some muscle fibres and extends nearly to the granule-vesicle $(\mathrm{w})$. As in uniporum and lutheri the single testis ( $\mathrm{t}$ ) lies on the right side. The ovaries (o) are paired. The ovocytes touch the wall of the intestine and probably receive their aliments directly from the gut.

The secondary male tube (q) is much more complicate than in uniporum (absent in lutheri). It has a caudal muscle-mantle (m), a middle glandular part (l), and a rostral bursa-like dilatation (s) that opens with a nozzle-like annulated tubule $(\mathrm{u})$ into the internal orifice of the very long antrum (a), near the oldest ovocyte. The only function of the secondary tube can be that presumed by Luther $(1947$, p. 34) : to assure auto-fecundation, if copulation does not happen. The principal copulatory organ $(p)$ ends with a bend.

The glands (y) that produce the mass of secretion (z) are compact, not epithelial and canaliculated as in uniporum. They lie rostrally to the glands (k) that furnish the granular secretion. The cuticular tubes or pieces (x) which occur within the mass of secretion are coiled up at one end. They may be cases of spermatophores, but as the sperms like the nuclei of all other tissues stain faintly, the function of these pieces can not be verified.

Lurus is a new genus of the Provorticidæ, the type of which, L. evelinx, n. sp. (Fig. 53-57), was found in fine gray sand of the bay of Santos, between tide-marks. The genus belongs to the group (Vejdovskya, Oekiocolax, Hangethellia) with separation of seminal and granule-vesicle, but is not specially near to one of them. L. evelinæ is the first Rhabdocoel (Neorhabdocoel) with a statocyst. This contains two statoliths, as occur in few Turbellaria (Westblad 1937, p. 86 ; Marcus 1945a, p. 66).

The length of the cylindrical, colourless body is $0,4 \mathrm{~mm}$. alive, the diameter $0,04 \mathrm{~mm}$. The epidermis is epithelial ; some sensory cilia occur chiefly on head and tail ; the secretion of the caudal glands (m) is adhesive and erythrophilous. The mouth (b) is terminal, the oral tube (ir) long. The brim of the pharynx doliiformis (f) is smooth; the radial muscles of the pharynx are strong. Cyanophilous glands (h) lie on the limit between the pharynx and the short syncytial intestine (i) that contains some diatoms and does not extend beyond the ovaries (o). Cells of Minot were not seen.

The two compact testes $(t)$ are ventral to the pharynx and either separated or confluent. Two efferent ducts (d) are constant. There is a thin-walled seminal vesicle $(\mathrm{s})$ and a reservatory $(\mathrm{k})$ of the granular secretion, in which the granules produced by numerous, volumous glands (j) are arranged in columns. The ejaculatory duct $(\mathrm{u})$ is coiled and for the most part cuticularized. One big cell (z) furnishes the cuticle, as in Proschizo- 
rhynchus oculatus Meix. and Togarma evelinæ Marc. the stylet is formed by one cell.

The gonopore (g) of the common antrum (a) is ventral, sub-terminal and surrounded by cement-glands ( $\mathrm{x}$ ). The vitellaria (v) composed of 6-12 successive cells on each side are separated from the ovaries (o). Both open into the "ootype" (y) (Luther 1948, p. 11) provided with shell-glands (r). The female genital canal (w) is weak. The ental part of the tubular bursa (p) is cuticularized. It has a lateral opening (q) to the parenchyma. Perhaps sperms pass through this aperture to the intestine, but this was not observed. The sub-terminal opening of the bursa leads to the cuticularized nozzle (n) of the ductus spermaticus (ds) that goes to the ootype (y).

Meixner divided the Schizorhynchidæ into 2 groups of genera: 1) with anterior pharynx and one pair of testes ; 2) with posterior pharynx and 2 pairs of testes. In 1949 we described a species with posterior pharynx and undivided testes (Trapichorhynchus tapes). Now we found another, from fine sand of the island of São Sebastião, with anterior pharynx and two pairs of testes. Therefore we restrict Meixner's groups to the position of the pharynx. The new species was put into the genus Proschizorhynchus and named $P$ atopus, n. sp. (Fig. 58-60), although it differs from $P$ oculatus Mx. and faeroeensis Mx. (1929, p. 766, 767 ; 1938, f. 67) by two pairs of testes. To none of the remaining genera of the first group, Carcharodorhynchus Mx., Paraschizorhynchus Mx., and Trapichorynchus Marc., the new species can be ascribed. It has paired seminal vesicles (s), a simple stylet (p), a volumous receptaculum (r), and a cuticular ring (n) at the base of the bursa. This ring is not analogous to the nozzle of the bursa of the Acoela, and the function of the bursa (b) can only be that of a bursa resorbiens. The canal of the bursa ("bursa-stalk", e) continues entally to the bursa as a bursa-intestinal communication, through which superfluous sperms (z) pass from the receptaculum (r) to the intestine. The latter contains setæ of Enchytraeids living in the same region of the sand (mean high-water line).

Schizorhynchoides martæ, n. sp. (Fig. 62-66), from muddy sand in water of sub-normal salinity (Cananea, southern coast of the State of São Paulo), is distinguished from all other Schizorhynchidæ by multiple (6-8 or more follicles), ventro-median testes (t) and a cirrus (p) enclosed in a muscular cirrus-pocket (z). As Trapichorhynchus tapes Marc. has an unarmed penis-bulb and the present species a cirrus, the stylet of the male copulatory organ must be eliminated from Meixner's diagnosis of the family (1928, p. 237). As the divided paired testes of Proschizorhynchus atopus and Schizorhynchoides diplorchis (sometimes called duplotestis Meixner 1928, p. 242, explanation of fig. 9 ; 1938, p. 131, 137) are not quite symmetrical, perhaps due to the filiform body, the disposition of the testes in the present species is less extraordinary. The pharynx (f) of Sch. martæ lies in the posterior half of the body, as in Sch. diplorchis and the two species of Schizorhynchus. The latter genus with undivided testes is farther distant from the present species than Schizorhynchoides diplorchis. It is true that diplorchis has an external vagina and martæ an atrial one (u), but the same difference occurs in two species (oculatus and faeroeensis) of Proschizorhynchus.

Also in well-stretched worms of Sch. martæ the epidermis is densely annulated. The sheath (d) of the proboscis has 2 nuclei, as in diplorchis. 
The two halves of the proboscis (e) are surrounded by a cuticularized membrane as in Trapichorhynchus tapes. Each proboscis-gland has 6 nuclei from which the tracts of secretion go to the base of the sheath. Two big seminal vesicles (s) open into the granule-vesicle $(r)$ that is enclosed in the muscle-mantle of the cirrus-pocket $(z)$. The cuticular setæ of the cirrus (p) are thin and faintly basophilous. The vitelloducts (vi) open together with the ovary (o) into the female genital canal (y). The vagina $(\mathrm{u})$ and the spermatic duct (x) are cuticular; the wall of the bursa seminalis (w) is loose. Two small tufts of glands (ev) occur where the spermatic duct joins the ovary.

Rosmarium, n. gen. with the type $R$. evelinæ, n. sp. (Fig. 67-69), from algæ in the littoral of the island of São Sebastião, belongs to the Holocoela Combinata Opisthoporata. Together with Scleraulophorus Karling it constitutes the family Scleraulophoridæ, characterized by the long, ectally tubular, entally dilated, oesophagus (Fig. 68, e, d). From Sclerauphorus it differs by 4 eyes, only one ventrally developed ciliated furrow $(w)$, the paired seminal vesicles $(\mathrm{s})$, the penis $(\mathrm{p})$ separated from the antrum ( $\mathrm{q}$ ) by a penissheath $(\mathrm{m})$, one median ovary $(\mathrm{o})$, and the vagina antralis $(\mathrm{u})$. Other characters are : the united opening (j) of the cephalic glands (h) and the non-ciliated pharynx (f) with very strong internal annular muscles.

Cylindrostoma netsicum, n. sp. (Fig. 70-72), was found on Sargassum stenophyllum below the mean low-water line of the island of São Sebastião. It has no ciliated furrow (against elongatum), and neither symbiontic algæ. in the intestinal cells nor a net of pigment in the parenchyma (against zooxanthella). The epidermal nuclei are depressed (against monotrochum). The pharynx begins in the middle of the body and slants ventro-caudally (against vanhöffeni). There are two medium-sized seminal vesicles (against gaussi). Cyanophilous glands open into a peculiar ventral concavity (k). The intestine is small. The ovaries are not separated from the vitellaria, the form of which, in ventral view, is drawn in Fig. 72. Alien sperms (w) occur between the ovocytes and in the adjacent parts of the vitellaria. Numerous testes, an unpaired seminal vesicle, and different granule-vesicle and penis separate Monoophorum triste Graff transferred to Cylindrostoma (Jones 1939) from C. netsicum.

Cylindrostoma was accepted in Reisinger's definition (1926, p. 444). The type of the genus, however, is not well established, as elongatum Lev. is not sufficiently known. C. ibeenum, n. sp. (Fig. 73-77), from algæ on the coast of the island of São Sebastião, has an unpaired median ovary, like Monoophorum and Enterostomula. In Pregermarium Stirewalt, Ferguson \& Kepner (1942) the unpaired ovary ist anterior to the ganglion. Of the Cylindrostoma-species mentioned in the discussion of $C$. netsicum, all the well-known ones have paired ovaries. Only in C. elongatum Gamble (1893, p. 485 t. 41 f. 19) the ovaries are perhaps united, as Graff (1913, p. 407) inferred from the not univocal drawing of a compressed worm. As Gamble distinguished Monoophorum with one ovary from Cylindrostoma with two, Graff's supposition is just as doubtful as the identity of Gamble's elongatum with Levinsen's. In any case $C$. ibeenum can not be identical with Gamble's species that has a very elongate and narrow body, pseudorhabdites, a crenulate border of the pharynx, radially disposed granular secretion and a pyriform penis, the distal portion of which is distinctly narrowed. 
Monoophorum tigacım, n. sp. (Fig. 78-82), from algæ of the island of São Sebastião has no rhabdites (against striatum and ruseri). The cephalic glands (e) open in a common pit (h) (against stri. and rus.). The pharynx is broader than long (against stri. and rus.) and its radial muscles are oblique. The inner pharyngeal pocket is deep. Club-shaped cells of Minot (m) occur, like in ruseri ; in striatum as in most Holocoela (Cumulata) they are absent. All male germ cells of one follicle (no tunica propria) are in the same phase. The male copulatory organ resembles that of striatum, not that of ruseri. The ovary (o) lies over the brain (c) (against stri. and rus.). The ovary and the vitellaria (v) are surrounded by the same tunica propria that forms the 2 ovovitelloducts, which do not unite (against stri. and rus.). The vagina (u) is short (against stri.), the ductus spermaticus (y) very long (against stri.) and runs in loops (against rus.) ; its ectal orifice, the nozzle, is formed by parallel tubules (against rus.).

Puzostoma, n. gen., belongs to the Plagiostomidæ. Its gonads are two ovariotestes (o) and two vitellaria (v). The pharynx plicatus (f) is followed by a long and wide oesophagus (e) with a cuticularized and musculous wall. The type, $P$ evelinæ, n. sp. (Fig. 83-88), was found between algæ in the littoral of the island of São Sebastião beneath the mean low-water line. This is the second case of true ovariotestes with tunica propria (membranous; nuclei not seen) in the Turbellaria. The first is Diopisthoporus longitubus Westbl. The ovariotestes of $P$. evelinæ are in open communication with the small common vesicle (w). The ovocytes leave the gonad in its anterior and dorsal region. Herewith they attain the space between the intestine and the vitellaria and come into the ciliated ovovitelloduct (Fig. 88). Nematocysts (n) of various types were seen in the gut cells, but they do not migrate to the epidermis. The sperms are similar to those of Plagiostomum porsildi Brandt. and P. acoluthum Marc. The copulatory organ belongs to Karling's type of $P$. makropharynx, and as the penis (p) is short, the organ resembles that of $P$. hartmeyeri. Weiss. The growing ovocytes show the small villosities known from Vorticeros auriculatum (Böhmig 1890, p. 327). It is strange that the two characters of the genus, the ovariotestes and the oesophagus, show closer relations to the Combinata than to the Separata. The hermaphrodite gland may be compared with the mixed diffuse germ-zone of Prolecithoplana lutheri Karl. The oesophagus is rather comparable with the corresponding organ of $P$. lutheri and Scleraulophorus cephalatus Karl. and specially with the anterior intestine of Plicastoma bimaculatum (Böhmig 1890, p. 399), than with the inner pharyngeal pocket of many Plagiostomidæ.

Promonotus erinaceus, n. sp. (Fig. 89-90) was collected with bait in the sand of the island of São Sebastião, in the mouth-region of a rivulet, where the water is fresh during low tide and brackish when the flood comes in. The oblong seminal and granular vesicle, the very long ejaculatory duct (d), the entally bulbous, ectally tubular penis ( $x$ ) with spines only on the basal bulb and the very large male antrum are the most important features of the species. Although Beklemischev (1927, p. 97) compared the tubular part of the copulatory organ in Promonotus with a cirrus, and also Meixner (1943, p. 465) mentioned a cirrus as a regular character of the genus, a true cirrus lying freely in an outer muscular pocket ("Cirrusbeutel") occurs only in $P$ schullzci $\mathrm{Mx}$. 
The following 5 species, orientalis (Bekl.), hyrcanus Bekl., schultzei Mx., villacæ Marc. and erinaceus Marc. all occur in lakes, estuaries, or seas with a salinity lower than that of the ocean. Some purely marine species are listed by Steinböck (1932, p. 329), but as these are not described, they can not be considered as certainly belonging to Promonotus.

The Monocelidinæ (the Monocelididæ with vagina) can' be arranged in the following provisory key :

1 Pharynx in the posterior half of the body, far from the anterior end of the gut

- Pharynx in the anterior third of the body, at the anterior end of the gut Coleophora (as Steinböck includes Monocelis alba with posterior pharynx in this genus, it has become heterogeneous).

2 Orifice of vagina ventral

- Orifice of vagina dorsal.

3 Vagina before penis

Togarma

- Vagina behind penis

4 Vagina far from penis

- Vagina close to penis or beginning within male antrum. ..

5 Epidermic nuclei intra-epithelial

- Epidermic nuclei depressed

6 With a musculous-glandular organ.

- Without a musculous-glandular organ.

7 Vagina externa.

- Vagina antralis.

8 Vagina connected with pre-penial bursa

- Vagina connected with post-penial bursa.

9 With musculous-glandular organ near female orifice; pharynx middle-sized. ... .. . . . . . . Peraclistus

- Without musculous-glandular organ; pharynx long. .. Necia

Monocelis tabira, n. sp. (Fig. 91-95), from fine sand of the coast of the island of São Sebastião and from the bay of Guanabara (Rio de Janeiro), belongs to the $M$. lineata-group of species with the male copulatory organ developed as an unarmed penis. The length of the preserved specimens is at most $1 \mathrm{~mm}$. (against fasciata) ; there are two separate eyes, each with one optic cell that is homogeneous and like a lens, as in longiceps (against balanocephala, gamblei, and viridirostris). The eyes are neither radiated nor surrounded by a transverse pigmented area (against fasciata). In about 50 worms in different developmental stages of the vitellaria the seminal bursa (Fig. 91, r) is very small, nearly rudimentary ; a posterior bursa does not occur. There are 2-6 testes (against lineata and longiceps). The distance between the vaginal pore (e) and the male pore $(p)$ is equal to that between the latter and the female pore (q) (against fuhrmanni). As a rule, the vagina is unpaired (against balanocephala), but one worm was found with two vaginæ that unite immediately inside their external pores. These lie symmetrically and are of different size.

Mesoda gabriellx hitherto only known from marine habitats (Marcus 1949 , p. 50) was also found in the brackish water region of the island of São Sebastião, and even in the sand of a very sluggishly flowing brook ammed off from the sea. Only spring floods reach this water. When thed 
material was collected, the possible salinity of the water could not be tasted ; it was inhabited by tadpoles and Cyprinodonts. Although salinity is higher and fluctuation less in the substratum than in the overlying water (Milne 1940), Mesoda gabriellæ proves to be a very euryhaline species.

Fig. 96 shows a bursa resorbiens (r) extended farther to the ventral surface than it was observed in the original material.

$N e c i a$, n. gen., with the type $N$. sopha, n. sp. (Fig. 97-102), from algæ in the upper littoral of the bay of Santos and the island of São Sebastiano, belongs to the Monocelididæ with vagina (=Monocelidinæ). The latter (u) runs from the common ovovitelloduct (wi) into the male antrum, caudally to the male copulatory organ. The nuclei of the epidermis are depressed, and the pharynx is very long (one fifth of the body-length). Three genera of the Monocelidinæ have vaginal and male pore close together (Mesoda) or united (Archilopsis, Archiloa); the type of the fourth, Coleophora, C. hirudo (Lev.), has an anterior pharynx.

Ectocotyla paguri Hyman (1944) has the same anterior position of the pharynx as $C$. hirudo and resembles this species found on the same hermit-crab ; the presumed embryos"are possibly eaten embryos of the Anomuran. Peraclistus oofagus that Westblad (1948) approximated to Ectocotyla feeds on the eggs of the Brachyuran on which it lives.

Steinböck (1932) and Bresslau (1933) give Fügenschuh as author of Coleophora and Peraclistus. But as no paper of the latter was published, Steinböck must be considered as author of these genera.

The vagina of Archilopsis unipunctata (Fabr.), as drawn by Meixner (1938, f. 61), does not communicate with the ovovitelloduct directly. In Archiloa rivularis and $A$. spinosa (for $A$. wilsoni, see Marcus 1949, p. 98) the vagina lies before the male organ, and a seminal (anterior) bursa occurs. Necia sopha has no bursa, and alien sperms were seen in the pre-pharyngeal part of the ovovitelloducts. While Mesoda gabriellæ and the mentioned species of Archilopsis and Archiloa have a cirrus, Necia has a very short ejaculatory duct, hardly separated from the antrum. The outer and inner surface of the pharynx as well as its oral and intestinal region are different; the female genital canal $(w)$ behind the vagina $(u)$ has a much higher epithelium than the ductus communis (wi). The cementglands (g) are strongly developed and the spatulate tail has red, brush-shaped adhesive glands (y) and blue glands (z) with rod-shaped secretion. Pyriform sensory cells connected with the latero-ventral nerves (Fig. 98) stain faintly.

Peraclistus itaipus, n. sp. (Fig. 103-104), found in the tubes of a Terebellid near the bay of Santos, is united generically with $P$. oofagus. The anatomy of the latter seems to have been misinterpreted by Friedmann (1924). As the efferent ducts ("vasa deferentia") were not seen, the musculous glandular organ with stylet was taken for the penis, although it did not contain any spermatozoa. The "flagellum" that really is the tubular eversible penis was ascribed to the bursa copulatrix that is a vagina antralis (as in Necia). Peraclistus is therefore the second genus of the Monocelidinæ (see key on p. 110) with the vagina hehind the penis. It differs from Necia by the musculous glandular organ, the penis, and the middle-sized pharynx. 
$P$ itaipus is separated from oofagus by the external vagina (v), the opening (y) of the musculous glandular organ (a), independent from the female orifice $(z)$, and the bursa resorbiens (w).

Philosyrtis Giard (1904, p. 1065) is a genus of the Otoplanidæ (Remane 1926 , p. 690) with a short, collar-shaped, ventrally directed pharynx and a ventral, transverse, not always distinct furrow that separates the anterior region. The nuclei are depressed on the ciliated creeping sole, normal on the rest of the body. The adhesive papillæ are digitiform. The male organ contains 6 pairs of setæ.

As the type, $P h$. monotoides, is only little known, this diagnosis refers, with certainty, only to Ph. eumeca, n. sp. (Fig. 106-110), from sand of the bay of Santos, and to another species described by Meixner in a not yet published key that we owe to Prof. Remane (Kiel). Meixner's species differs from eumeca by other penial setæ.

Kata leroda, n. sp. (Fig. 111-115), from sand of the shore of the island of São Sebastião, is smaller (2,0 mm long.) than K. evelinæ $(8 \mathrm{~mm}$.). Although the pharynx of $K$. leroda lies farther in front, the caudal region of the body is proportionally much shorter. The ventral cilia extend to the genital pore (in evelinæ only to the beginning of the pharynx). Other differences are : the scarcity of adhesive papillæ, the absence of cyanophilous cephalic glands, the weaker cutaneous muscles, especially on the back, the position of the nuclei of the ciliated sole beneath the longitudinal muscles like in the rest of the body, not between an external and an internal layer of muscles as in evelinæ, scattered cells of Minot, a very short post-pharyngeous gut, a bulbous, not conical (evelinx) male organ and a single bursa, vagina and dorsal pore (paired in evelinæ). The canal between the efferent duct and the intracellular intestinal vacuoles described for evelinæ occurs also in leroda.

Nematoplana asita, n. sp. (Fig. 116-127), from sand on the beach of the island of São Sebastião, is intermediate in size (up to $7 \mathrm{~mm}$.) between $N$ coelogynoporoides $\mathrm{Mx}$. (more than $12 \mathrm{~mm}$.) and $N$ naia Marc. (up to 3 $\mathrm{mm}$.). Against the syncytial epidermis with filiform nuclei of coelogyn., $N$. asita has a distinct epithelium with flat nuclei. Sphincters (Meixner 1938, f. $44, \mathrm{sph}$ ) at the root of the cephalic intestine were not seen. About 10 ovaries occur on either side (coelogyn. 3-4). Only in the outer pharynxepithelium the nuclei are depressed (in naia in the outer and inner), and some of the glands with basophilous secretion open on the outer side (in naia all on the rim). There are two (in naia one) true (principal) seminal vesicles (s) that receive the efferent ducts (in naia they go into the accessory vesicle), and the stylet ( $p$ ) has one spike, not two as in naia.

Like in naia the pharynx of asita, that measures $11,2 \%$ of the body-length of the full-grown immature worm (Fig. 123, 126), degenerates in the female phase (Fig. 125, 127, f) to $3,5 \%$ of the total length. The vitellarian cells in the ovarian region (w) of the mature worm differ from the ordinary vitellarian (v) aspect; they are finely granular and neutrophilous. The cytoplasm of the growing ovocytes (Fig. 119, o) shows the same transformations (wi) going out from the nucleus, that Böhmig (1890, p. 320-328) described from various Plagiostomidæ. 
The tunica propria of the ovaries becomes distinct only in the mature female phase and then every sac of the tunica contains only one full-grown ovocyte. The row of testes that reaches the base of the pharynx in the young female phase (Fig. 117, t) disappears from the region of the growing ovaries (Fig. 124). Then the last testicular follicles lie $0,7 \mathrm{~mm}$. before the base of the pharynx. Transverse muscles (Fig. 120, 125, z), that lie dorsally and in the middle of the body, develop in the later female phase. By the developing vitellaria the two original series of testes are compressed to a single ventro-median row (Fig. 124).

Tabaota, n. gen., with the type T. curiosa, n. sp. (Fig. 128-141), from sand of the island of São Sebastião, is a Nematoplanid (length : 2-18 mm.) that differs from Nematoplana by : 1) absence of eyes ; 2) presence of two post-cerebral refractive bodies, like those of Stenostomum (photo-receptors of the type of visual cells with a phaosoma), adjacent to the principal nerve-cords ; and 3) the intestine coalesced with the skin in a dorso-caudal area. The cells of this terminal tube are not digestive, and the body-wall of the area has no epidermal nuclei, basal membrane and muscle layers (Fig. 139, $140, v)$. Living worms show faeces in the terminal tube and the thin-walled vesicle formed by the coalesced area, but evacuation was not seen. Notwithstanding the structure suggests that a transitory anal aperture exists. This is the first case of such an organ in other than Polyclad Turbellarians.

Cephalic glands are absent. The longitudinal muscles are disposed in bundles that are thicker ventrally than dorsally. The capsule of the brain continues around the whole length of the principal nerve-cords (Fig. 135), not only around the roots as in Holocoela. This membrane is not produced by insufficient fixation (Bdelloura ; Böhmig), but is really non-cellular and comparable to the neurilemma of Nemertines. Two extra-capsular ganglia, antero-laterally to the brain, correspond to the "äusseren Körnerhaufen" of the Polyclads. In the head of living worms terminal organs of the excretory system were seen (Fig. 130, r). The body of the pharynx, that is a pharynx plicatus, has a dorso-median concavity that lodges the connecting canal $(\mathrm{y})$ between the oesophagus ( $\mathrm{j}$ ) and the postpharyngeal gut. The nuclei of the epithelia of the pharynx lie as in Nematoplana asita. Part of the pharyngeal glands (g) open on the outer side, dorsally to the mouth (b). The pharynx-pocket (z) has an epithelium unusually rich in nuclei and surrounds the whole pharynx (f) and the connecting canal (Fig. 138). As in Nematoplana naia and $N$. asila the length of the pharynx that is $0,3-0,45 \mathrm{~mm}$. in the full-grown immature worm of $T$. curiosa diminishes to $0,025 \mathrm{~mm}$. in the female phase, and the region behind the pharynx grows from $0,3-0,4 \mathrm{~mm}$. to $1-1,2 \mathrm{~mm}$. (Fig. 134). The intestinal cells were seen to incorporate erythrocytes of fish (Fig. 131 , pe). The diameter of worms that had just fed on the bait is $0,2 \mathrm{~mm}$., of which $0,176 \mathrm{~mm}$. corresponds to the contents of the gut and $0,012 \mathrm{~mm}$., on each side, to the wall of the body ( 7 micra) and the gut ( 5 micra). During digestion the worms are no longer dilated. Of the total diameter of 0,154 $\mathrm{mm}$. in this phase $0,01 \mathrm{~mm}$. on each side corresponds to the body-wall and $0,134 \mathrm{~mm}$. to the cells of the gut, which have become so high that the cavity disappears. The claviform shape of the head is conditioned by the turgesence of the cells of the solid cephalic intestine (l), a supporting organ frequent in Proseriata living in sand. 
There are up to 500-600 testicular follicles (t) on each side. As in Nematoplana asita the testes disappear from the region of the growing ovaries. The efferent ducts (de) are paired up to the ciliated bulb $(\mathrm{u})$ where the cuticular stylet (s) inserts. They do not form seminal vesicles; their most ectal cavities are granule-vesicles $(\mathrm{k})$ that contain the secretion of circumjacent glands. The stylet with its spur and the volumous formative cell (eu) likens that of Togarma evelinx. The female organs differ from those of Nematoplana asita by the lesser number of ovaries (no more than 5) and by the big masses of neutrophilous glands (a) that differ from typical eryth rophilous cement-glands by their staining.

Contrary to Togarma and the two other statocyst-less Proseriata (Nematoplana naia and $N$ asita) Tabaota curiosa does not glide downwards in the inclined dish, as also species with statocyst do. When the water and the sand in the dish are shaken, the worms of $T$ curiosa come out of the sand with two thirds of their length. When the water becomes calm again, they withdraw at once ; only worms with injured heads stay outside.

Adenoplana evelinæ, n. sp. (Fig. 142-147), from algæ of the upper littoral of the island of São Sebastião, is the second species of the genus, introduced by Stummer-Traunfels (1933, p. 3510) for Polycelis obovata Schmarda. $A$. evelinæ that alive was $25 \mathrm{~mm}$. long and $12 \mathrm{~mm}$. broad differs from all other known Discocelidæ (key of genera, p. 76) by marginal eyes around the entire body. Like $A$. pobovata the new species has a granule-vesicle (k). This seems incompatible with the diagnosis of the family, but as the atrial muscles involve the vesicle, and the vesicle is in broad communication (s) with the antrum (a), it may perhaps be considered as belonging to the roof of the antrum. It is true that Stummer-Traunfels defined the vesicle as intercalar, but this terminology is not adequate to the position of the organ. The absence of a penis (penis-papilla) in Adenoplana is a difficulty more for maintaining the genus in the Discocelidæ.

The seminal vesicles enter the granule-vesicle separately, without uniting to form an ejaculatory duct. The accessory male pore (r), the function of which is not known, does not communicate with the orifice (p) of the antrum as in obovota. Also the atrial lobes and the external vagina (v) are different in obovota and evelinæ. In other respects, f. ex., the musculous-glandular organs (h, Fig. 146) and the horse-shoe shaped Lang's vesicle (Fig. 142, l), the two species are very similar.

An emended key of the genera of the family Latocestidæ is given on p. 78.

Hoploplana divæ, n. sp. (Fig. 148-151), from algæ of the upper littoral of the island of São Sebastião, has nearly cylindrical papillæ all over the back. These differ from the papillæ of $H$. villosa (Lang) by their shape in the living animals (hair-like in villosa) and by their rhabdites (after Lang, Kato, and Stummer-Traunfels absent in the papillæ of villosa). Besides the numerous dorsal and ventral dermal rhabdites some depressed cells with eosinophilous secretion may possibly furnish adenal rhabdites. Such evidently occur also in $H$. villosa (Kato 1937a, p. 217). The other Polyclads with adenal rhabdites have recently been listed by Corrêa (1949, p. 179),

H. divæ is the first species of the genus with a penis-pocket that is separated from the male antrum by a well developed penis sheath (k). 
The cerebral eyes of $H$. villosa are still more diffuse (Kato, l. c., f. 7 in the text) than those of $H$. divx, and there also differences in the topography of the female efferent organs. $H$. papillosa has stout tubercles confined to the middle of the back and other colours than the pink $H$. divæx, the red intestine of which shines through the integument. The other species of the genus mentioned on p. 80 have no papillæ.

Pseudoceros evelinæ, n. sp. (Fig. 152-157), red, brimmed with orange and black, was found on Ascidiæ compositæ near Santos, below the low-water line. The species of Pseudoceros inhabit the warm and temperate-warm seas. The two specimens of $P$. velutinus captured at Lat $41 .^{\circ}$ N., Long. $55^{\circ}$ W. had probably been transported there by the Gulf-Stream. P. yessoensis from temperate-cold water differs from the other species by the cerebral eyes disposed in elongate clusters and the backwards directed penis (also in limbatus Hasw.). The Bermudas, the Mediterranean, Hokkaido and Corea are the northern, South Africa (St. James, False Bay) and Port Jackson the southern limits of the genus.

$P$. liparus is a new name introduced for limbatus Hasw. (non limbatus Leuck.), strigosus for striatus (Schmarda) (non striatus Kelaart). Licheniplana Heath \& MacGr. is a synonym to Acanthozoon Collingw. which should be used for the species with small dorsal papillæ (nos. 1, probably 40, 46, 51 of the list on p. 84-88); No. 24 should be removed to Dicteros Jacubowa.

Besides $P$ evelinæ no other red species is known from the Atlantic. Red mediterranean and indo-pacific species are : nos. 10 (very small tentacles, pharynx bell-shaped, without folding); 31 (not described; the figure was not seen; after Laidlaw 1903a, p. 10 allied to regalis and therefore probably with small tentacles) ; 36 (mouth situated just behind the brain) ; 46 (with dorsal papillæ) ; 47 (has white spots, and the inner line of the border is whitish-blue) ; 48 (dark red with white middle-line) ; 49 (with violet to brown spots and whitish median line); 54 (the tentacles are simple folds ; the male copulatory organ is single) ; 59 (tentacles small) ; 61 (mature worms very small, $5 \mathrm{~mm}$. long, $4 \mathrm{~mm}$. broad).

Some species, the colour of which is not known from living specimens, can be distinguished from evelinæ by the shape of the tentacles, the distribution of the tentacular eyes, and other characters. The new species has 4 groups of tentacular eyes : 1) dorso-distal, 2) dorso-proximal, 3) ventro-distal and 4) ventro-proximal ones (Stummer-Traunfels 1933, p. 3545, note). The tentacles liken the ears of a chinchilla. The pharynx is much folded. The male organs are paired and completely separated. The seminal canals are moniliform and form various accessory seminal vesicles (m) followed by one principal (muscular) seminal versicle each (l). The penis ( $p$ ) within its penis-pocket (bo), and the antrum, are directed backwards. There are six folds ( $t$ ) of the male antrum, besides the penis-sheath (o), and the tubes between these folds are provided with sphincters (s).

Cycloporus gabriellæ, n. sp. (Fig. 160-166) was found on the coast of the island of São Sebastião between algæ grown on rocks and on the muddy bottom below the low-water line. It has a smooth epidermis, and besides 
the unpaired antero-median branch (i) of the intestine 10 pairs of intestinal diverticles (against 6-7 in papillosus) that ramify dichotomously, but do not anastomose (against papillosus and variegatus). The end-vesicles of the intestine (Fig. 161, 162) are joined immediately to the peripheric ramifications of the diverticles ( $\mathrm{k}$ ), in opposition to variegatus with a long, thin canal between each vesicle and the corresponding terminal branch of the intestine.

In our material the vesicles never contain faeces, only liquid, but Lang also saw the passage of undigested food. The external pore lies between solid epidermal cells without rhabdites. The communication from the peripheric part of the diverticle $(\mathrm{k})$ to the vesicle is an intra-cellular canal that runs through 2 cells (d), one behind the other, and is closed by a third cell (t). Fine muscle-fibres (e) suspend the vesicle. Rhabdites are specially numerous on the ventral side of the anterior border. The penis-papilla is weakly cuticularized. The penis-sheath is as long as the papilla. The groups of cerebral eyes (n) are broad, not lengthy as in the european specimens of papillosus. It is true that the cerebral eye-groups of papillosus var. misakiensis are also short, and it seems necessary to consider the japanese form of papillosus as a separate species.

Dark-green larvæ $(0,51 \mathrm{~mm}$.$) and a newly metamorphosized worm$ $(0,54 \mathrm{~mm}$.) were found in the algæ together with the adult animals of $C$. gabriellæ. One of the larvæ had male organs (Fig. 166). The body is somewhat flattened and corresponds to Lang's stage E; it is $0,52 \mathrm{~mm}$. long. Its parenchyma has the same dark-green granules as the preceding larva (Fig. 163) and the young worm (Fig. 165). As we found also larger immature worms $(1-2 \mathrm{~mm}$.) with the same colour and with some end-vesicles of the intestine, the whole series proves to belong to C. gabriellx.

The primordials of the pharynx (f), the pharyngeal pocket (a), and the sucker (v) are more developed than in Graffizoon lobatum Heath. The parenchyma contains a great number of nuclei, not drawn in Fig. 166, on purpose to bring out the inner organs. These nuclei probably belong to the formative cells of the definitive intestine. The larval intestine (i) is histologically less differenciated than that of the preceding stage in Lang's section $(1884$, t. $38 \mathrm{f}$. 2). This may be due to the prepharyngeal copulatory organs, the position of which may delay the development of the pharynx and therewith that of the other parts of the digestive tract.

The seminal vesicle (s), filled with sperms, the penis ( $p$ ) with its sheath $(\mathrm{z})$ and the male antrum (d) lie before the mouth and the stomodaeum as in G. lobatum, the seminal vesicle even within the annular primordial of the definitive pharynx. A granule-vesicle does not exist. 4-5 testicular follicles ( $t$ ) lie in the posterior region of the body. As no female organs were Jound, it is not known whether the larva is protandrous, or sexes are sepaJated in the larvæ. In any case we presume that the larval sexual stage is not a definitive one, but will pass through normal metamorphosis and an immature juvenile phase to the full-grown worm that becomes mature again. This phenomenon is known as dissogony (Ctenophora, some $\mathrm{Ne}$ reids).

The small species of Acerotisa, f. ex. A. notulata (Bosc ; Hyman 1939) with $1 \mathrm{~mm}$. length, and the small pelagic Polyclads (Palombi 1924) may be 
understood as neotenic forms (Stummer-Traunfels 1933). Neoteny is the combination of specifically definitive growth with larval or juvenile characters. Frequently, but not always (giant tadpoles), neotenic animals are sexually mature. Many text-books written in english do not distinguish between neoteny and paedogenesis, that is reproduction, specially parthenogenesis, in larval or juvenile not definitive stages (sporocysts, rediæ, larvæ of Cecidomyidæ). Heath (1928) who called Graffizoon lobatum a case of pædogenesis, and the authors writing in german (Meixner. 1930, 1938 ; Bock 1931 ; Bresslau 1933 ; Stummer-Traunfels 1933) who mentioned it as a neotenic Euryleptid, agree in considering it a definitive Polyclad that had to be named. But its very small size $(0,57-0,73 \mathrm{~mm}$.) and still more the primordial of a definitive pharynx insinuate, that it is the sexually mature larva of one of the Euryleptidæ of Monterey-Bay and also a case of dissogony.

Prosthiostomum matarazzoi, n. sp. (Fig. 167-171,181), many specimens from algæ of the upper littoral of the island of São Sebastião, has a light greenish-gray back, in mature worms nearly continuous marginal eyes (83 in the biggest, $20 \mathrm{~mm}$. long worm), 2 ventral eyes (y), and up to 18 cerebral eyes on each side. The muscles of the accessory vesicles are united. The uteri of both sides communicate behind the sucker. 42 other species of the genus are listed (p. 96) with their disjunctive characters.

Prosthiostomum gilvum, n. sp. (Fig. 172-175) from the same locality as the preceding species has an orange coloured back without spots or stripes. The marginal eyes are small, very numerous (150-165) and uninterrupted in the middle. There are 2 ventral eyes and two parallel groups of small and numerous (37-46 in each group) cerebral eyes. The accessory vesicles are separate. The disjunctive characters of the other Prosthiostomum-species are mentioned on p. 99. The two available worms show the same accumulation of faecal masses in the terminal part (j) of their gut as $P$ matarazzoi. In the intestine of one of the worms a specimen of the Polyclad Acerotisa bituna Marc. and a pharynx of a Prosthiostomum were found. When several individuals of Prosthiostomum are together in a dish, they touch one another with the protruded pharynx. So they certainly also do in the tufts of algæ (Jania rubens L.), where they hide from day-light, and while creeping about with everted pharynx the latter can easily be torn off by another individual.

Prosthiostomum cynarium, n. sp. (Fig. 176-180), from algæ of the upper littoral of the island of São Sebastiano, is a small, ivory-coloured or grayish species that is mature with the length of $5 \mathrm{~mm}$. There are up to 10 cerebral eyes in one group. The series of marginal eyes is a little interrupted in the middle of the anterior border. One specimen shows how much the sucker is dilated when everted (Fig. 176), the diameter is then $0,35 \mathrm{~mm}$.; in the retracted sucker it is $0,09 \mathrm{~mm}$. (Fig. 180). As in the previously described species of Prosthiostomum, $P$ matarazzoi and $P$ gilvum, the precerebral ganglia are very much reduced. The efferent ducts of $P$. cynarium are not united in the posterior region of the body, but the two posterior branches of the uteri have a transverse communication. The penis-papilla is directed almost dorsally; the accessory vesicles are separated. 


\section{LITERATURA}

An der Lan, H. 1936, Ergebnisse einer .. Reise in Grönland. 7. Acoela I. Vidensk. Meddel. Dansk Naturh. Foren. v. 99, p. 289-330 t. 1-3. Köbenhavn. 1939, Zur rhabdocoelen Turbellarienfauna des Ochridasees (Balkan). Sitz. Ber. Ak. Wissensch. Wien Math. Nat. Klasse v. 148 Abt. 1 no. 5-6, p. 195-254. Wien. Beauchamp, P. de 1910, Archiloa rivularis n. g. n. sp. Turbellarié Alloeocoele d'eau douce. Bull. Soc. Zool. France v. 35, p. 211-219. Paris. 1913, Un nouveau Rhabdocoele marin, Prorhynchopsis minuta n. g. n. sp. Bull. Soc. Zool. France v. 37 (1912) no. 10 (1913), p. 299-302. Paris. 1920, Turbellariés et Hirudinés. 1. série. Arch. Zool. Expér. Génér. v. 60, p. 177-219 t. 5-6. Paris. 1921, Sur un nouveau Plagiostomum, etc. Bull. Soc. Zool. France v. 46, p. 169-176. Paris. 1927, Rhabdocoeles des sables à Diatomées d'Arcachon. Bull. Soc. Zool. France v. 52, p. $351 \& 386$ (p. 1-15 da separata). Paris. Beklemischev, W. 1922, Nouvelles contributions à la faune du lac Aral. Russ. Hydrobiol. Zeitschr. v. 1, p. 276289. Saratov. 1927, Ueber die Turbellarienfauna des Aralsees. Zool. Jahrb. Syst. v. 54 (1928) fasc. 1-2 (1927), p. 87-138 t. 2. Jena. Blanchard, E. 1847, Recherches sur l'organisation des vers. Ann. Sci. nat. sér. 3 Zool. v. 7, p. 87-128 ; v. 8, p. 119-149, 271 275 t. 8-9. Paris. Bock, S. 1913, Studien über Polycladen. Zool. Bidr. Uppsala v. 2, p. 31-344 t. 3-10. Uppsala. 1922, Two new Cotylean genera of Polyclads from Japan, etc. Ark. Zool. v. 14 no. 13, p. 1-31 t. 1-2. Stockholm. 1927, Apidioplana eine Polycladengattung mit muskulösen Drüsenorganen. Göteb. K. Vetensk. Vitterh. Samh. Handl. 4. Följd. v. 30 no. 1, p. 1-116. Göteborg. 1931, Die Polycladen der D. Südpolar Expedition. D. Südp. Exp. v. 20 (Zoologie), p. 259-304 t. 44-47. Berlin (W. de Gruyter). Böhmig, L. 1890, Untersuchungen über rhabdocoele Turbellarien. II. Plagiostomina und Cylindrostomina Graff. Zeitschr. wiss. Zool. v. 51 (1891) fasc. 2 (1890), p. 167-479 t. 12-21. Leipzig. 1902, Turbellarien. Rhabdocoeliden und Tricladen. Hamb. Magalh. Sammelreise v. 3, p. 1-30 t. 1-2. Hamburg. 1906, Tricladenstudien I. Zeitschr. wiss. Zool. v. 81, p. 344-504 t. 12-19. Leipzig. 1914, Die Rhabdocoelen Turbellarien und Tricladen der D. Südpolar Expedition 1901-1903. D. Südp. Exp. v. 15 Zoologie v. 7, p. 1-33 t. 1-3. Berlin (W. de Gruyter). Brandtner, P. 1934, Plagiostomidæ. Ergebnisse . Reise in Grönland. Vidensk. Meddel. Dansk Naturh. Foren. v. 97, p. 87-150 t. 1-4. Köbenhavn. Bresslau, E. 1933, Turbellaria, W. Kükenthal \& Th. Krumbach, Handb. Zool. v. 2, 1. ${ }^{\text {a }}$ metade, p. 52-293, 310-320. Berlin \& Leipzig (W. de Gruyter). Brinkmann, A. 1905, Studier over Danmarks Rhabdocöle og Acöle Turbellarier. Vidensk. Meddel. Dansk Naturh. Foren. 1906, IV + 159 p. (paginação da separata) t. 1-5. Köbenhavn. Buchner, P. 1930, Tier und Pflanze in Symbiose. 2. ${ }^{\mathrm{a}}$ ed. XX +900 p. 336 fig. Berlin (Gebr. Borntræger). Carter, G. S. 1940, A general Zoology of the Invertebrates. XXVIII + 509 p. 172 fig. New York (MacMillan). Collingwood, C. 1876, On thirty-one species of Marine Planarians, etc. Transact. Linn. Soc. London 2. ser. (Zoology) v. 1 pars 3, p. 83-98 t. 17-19. London. Corrêa, D. D. 1948, Ototyphlonemertes from the Brazilian Coast. Com. Zool. Mus. Montevideo v. 2, no. 49, p. 1-12 t. 1-2. Montevideo. 1949, Sôbre o gênero Zygantroplana. Bol. Fac. Fil. Ci. Letr. Univ. S. Paulo Zoologia no. 14, p. 173-218 t. 1-5. São Paulo. Crozier, W. J. 1917, On the pigmentation of a Polyclad. Proc. Americ. Ac. Arts Sci. v. 52, p. 723-730 t. 1. Cambridge, Mass. Curtis, W. C. \& Guthrie, M. J. 1927, Textbook of General Zoology. XV + 585 p. 308 fig. New York (Wiley) \& London (Chapman \& Hall). Diesing, K. M. 
1862, Revision der Turbellarien. Abtheilung : Dendrocoelen. Sitz. Ber. math. naturw. Cl. Akad. Wiss. Wien. v. 44, 1. Abt. (1861), p. 485-578. Wien. du Bois-Reymond Marcus, E. 1948, Further Archiannehids from Brazil. Com. Zool. Mus. Montevideo v. 2, no. 48, p. 1-17 t. 1-5. Montevideo. 1949, Phoronis ovalis from Brazil. Bol. Fac. Fil. Ci. Letr. Univ. S. Paulo Zoologia no. 14, p. 157-172 t. 1-3. São Paulo. Francotte, P. 1898, Recherches sur la maturation, la fécondation et la segmentation chez les Polyclades. Arch. Zool. Expér. Génér. sér. 3 v. 6, p. 189-298 t. 14-19 bis. Paris. Friedmann, G. 1924, Monocelis oofaga, nov. sp., eine neue parasitische Alloeocoele. Bull. Inst. rech. biol. Univ. Perm. v. 3, p. 81-92, 1 t. Perm. Gamble, F. W. 1893, Contributions to a knowledge of British marine Turbellaria. Quart. Journ. Micr. Sci. n. ser. v. 34, p. 433-528 t. 39-41. London. Giard, A. 1904, Sur une faunule caractéristique des sables à Diatomées d'Ambleteuse. III. Les Gastrotriches aberrants. C. R. Soc. Biol. v. 56, p. 1063-1065. Paris. Graff, L. 1874, Zur Kenntnis der Turbellarien. Zeitschr. wiss. Zool. v. 24, p. 123-160 t. 14-19. Leipzig. 1878, Kurze Berichte über fortgesetzte Turbellarienstudien. Zeitschr. wiss. Zool. v. 30 Suppl., p. 457-465. Leipzig. 1882, Monographie der Turbellarien. I. Rhabdocoelida. XII + 442 p. 20 t. Leipzig (não visto ; citado seg. Graff 1904-08, p. 1805). 1892, Pelagische Polycladen. Zeitschr. wiss. Zool. v. 55 (1893) fasc. 2 (1892), p. 189-219 t. 7-10. Leipzig. 1904-1908, Turbellaria. I. Acoela und Rhabdocoelida. H. G. Bronn Kl. Ordn. v. 4 Abt. Ic, p. I-XXII, 1733-2599 t. 1-30. Leipzig (Winter). 1905, Turbellaria I. Acoela. Das Tierreich (K. Preuss. Ak. Wiss.) fasc. 23, VIII + 35 p. Berlin (Friedländer). 1905a, Marine Turbellarien Orotavas, etc. II. Rhabdocoela. Zeitschr. wiss. Zool. v. 83, p. 68-150 t. 2-6. Leipzig. 1911, Acoela, Rhabdocoela und Alloeocoela des Ostens der Vereinigten Staaten von Amerika. Zeitschr. wiss. Zool. v. 99 (1912) fasc. 1 (1911), p. 1-108 t. 1-4. Leipzig. 1913, Turbellaria. II. Rhabdocoelida. Das Tierreich (K. Preuss. Ak. Wiss.) fasc. 35, XX + 484 p. Berlin (Friedländer). Guyer, M. 1941, Animal Biology. XIX + 723 p. 423 fig. New York \& London (Harper). Hadenfeldt, D. 1929, Das Nervensystem von Stylochoplana maculata und Notoplana atomata. Zeitschr. wiss. Zool. v. 133, p. 586-638. Leipzig. Hallez, P. 1892, Classification des Triclades. Bull. Soc. Zool. France v. 17, p. 106-109. Paris. 1904, Notes fauniques. Arch. Zool. Expér. Génér. sér. 4 v. 3 (1905) Notes et Revue no. 3 (1904), p. 47-52. Paris. Haswell, W. A. 1905, Studies on the Turbellaria. Parts I \& II. Quart. Journ. Micr. Sci. n. ser. v. 49 (1906) no. 195 (1905), p. 425-467 t. 25-27. London. 1907, Observations on Australian Polyclads. Transact. Linn. Soc. Lond. ser. 2 (Zool.) v. 9, p. 465-485 t. 35-37. London. Heath, H. 1928, A sexually mature turbellarian resembling Müller's larva. Journ. Morph. Phys. v. 45, p. 187-207 t. 1-2. Philadelphia, Pa. Heath, H. \& McGregor, E. A. 1912, New Polyclads from Monterey Bay, California. Proc. Ac. Nat. Sci. Philadelphia v. 64 (1912-1913), p. 455-488 t. 12-18. Philadelphia, Pa. Hofsten, N. v. 1907, Studien über Turbellarien aus dem Berner Oberland. Zeitschr. wiss. Zool. v. 85, p. 391654 t. 22-27. Leipzig. 1918, Anatomie, Histologie und systematische Stellung von Otoplana intermedia Du Plessis. Zool. Bidr. Uppsala v. 7, p. 1-74 t. 1-2. Uppsala. Hyman, L. H. 1937, Reproductive system and copulation in Amphiscolops langerhansi, etc. Biol. Bull. v. 72, p. 319-326. Lancaster, Pa. 1939, Acoel and Polyclad Turbellaria from Bermuda and the Sargassum. Bull. Bingh. Oceanogr. Coll. (Peabody Mus., Yale ${ }_{\star}^{\top}$ Univ.) v. 7 no. 1, p. 1-26 t. 1-9. New Haven, Conn. 1939a, Some Polyclads of the New England Coast, etc. Biol. Bull. v. 76, p. 127-152. Woods Hole, Mass. 1939b, Polyclad Worms 
collected on the Presidential Cruise of 1938. Smithson. Miscell. Coll. v. 98 no. 17, p. 1-13. Washington, D. C. 1940, The Polyclad Flatworms of the Atlantic Coast of the United States and Canada. Proc. U. S. Nat. Mus. v. 89 no. 3101, p. 449-495. Washington, D. C. 1944, Marine Turbellaria from the Atlantic Coast of North America. Americ. Mus. Novitates no. 1266, p. 1-15. New York. 1944a, A new Hawaiian Polyclad Flatworm associated with Teredo. Occas. Pap. Bernice P. Bishop Mus. v. 18 no. 4, p. 73-75. Honolulu, Hawaii. Jacubowa, L. 1906, Polycladen von Neu-Britannien und Neu-Caledonien. Inaug. Diss. Phil. Fak. (Math. Nat. Sekt.) Zürich. 46 p. 5 t. (também : Jen. Zeitschr. Naturw. v. 41) Jena. Jensen, O. S. 1878, Turbellaria ad litora Norvegiæ occidentalia. 97 p. 8 t. Bergen (Eide). Jones, E. R. 1939, Further observations on the Turbellaria of the eastern United States. Proc. Virginia Acad. Sci. 1939, p. 35 (citado seg. Zool. Rec. 1942). Kaburaki, T. 1923, The Polyclad Turbellarians from the Philippine Islands. Smithson. Inst. U. S. Nat. Mus. Bull. 100 v. 1, p. 635-649 t. 53-54. Washington, D. C. Karling, T. G. 1940, Zur Morphologie und Systematik der Alloeocoela Cumulata und Rhabdocoela Lecithophora. Acta Zool. Fenn. no. 26, p. 1-260 t. 1-17. Helsingforsiæ. 1943, Studien an Halammovortex nigrifrons (Karling), etc. Acta Zool. Fenn. no. 37, p. 1-23 t. 1-2. Helsingforsiæ. Kato, K. 1934, Polyclad Turbellarians from the neighborhood of the Mitsui Institute, etc. Jap. Journ. Zool. v. 6, p. 123-138 t. 1. Tokyo. 1937, Three Polyclads from Northern Japan. Annot. Zool. Japon. v. 16, p. 35-38. Tokyo. 1937a, Polyclads collected in Idu, Japan. Jap. Journ. Zool. v. 7, p. 211-232 t. 14-15. Tokyo. 1937b, Thirteen new Polyclads from Misaki. Jap. Journ. Zool. v. 7, p. 347-371 t. 20-22. Tokyo. 1938, Polyclads from Seto, Middle Japan. Jap. Journ. Zool. v. 7, p. 577-593 t. 38-39. Tokyo. 1938a, Polyclads from Amakusa, Southern Japan. Jap. Journ. Zool. v. 7, p. 559-576 t. 36-37. Tokyo. 1939, The Polyclada of Mutsu Bay. Sci. Rep. Tôhoku Imp. Univ. ser. 4 v. 14, p. 143-153 t. 8-9. Sendai. 1939a, Polyclads in Onagawa and Vicinity. Sci. Rep. Tôhoku Imp. Univ. ser. 4 v. 14, p. 65-79 t. 3-4. Sendai. Kepner, Wm.

A. \& Helvestine, F. jr. 1920, Pharynx of Microstoma caudatum. Journ. Morphol. v. 33, p. 308-323 t. 1-3. Philadelphia, Pa. Kepner, Wm. A. \& Taliaferro, W. H. 1912, Sensory epithelium of pharynx and ciliated pits of Microstoma caudatum. Biol. Bull. v. 23, no. 1, p. $42-58$ t. 1. Woods Hole, Mass. Laidlaw, F. A. 1902, The marine Turbellaria, etc. Fauna Geograph. Maldive Laccadive Archip. v. 1 part 3, p. 282-312 t. 14-15. Cambridge. 1903, A collection of Turbellaria Polycladida from the Straits of Malacca (Skeat Exp.). Proc. Zool. Soc. London 1903 v. 1, p. 301-318 t. 23. London. 1903a, Notes on some Marine Turbellaria from Torres Straits and the Pacific, etc. Mem. Proc. Manchester Lit. Phil. Soc. v. 47 part 2 no. 5, p. 1-12. Manchester. 1903b, Suggestions for a Revision of the Classification of the Polyclad Turbellaria. Mem. Proc. Manchester Lit. Phil. Soc. v. 48 part 1 no. 4, p. 1-16. Manchester. 1904, On the Polyclad Turbellaria. Rep. Pearl 'Oyster Fish. Gulf of Manaar (W. A. Herdman) part 2 Suppl. Rep. 9, p. 127-136 1 t. London. Lang, A. 1881, Der Bau von Gunda segmentata, etc. Mittheil. Zool. Stat. Neapel v. 3 (1882) fasc. 1-2 (1881), p. 187-251 t. 12-14. Berlin. 1884, Polycladen. Monogr. 11, Fauna Flora Golf. Neapel. IX + 688 p. 39 t. Leipzig (Engelmann). Löhner, L. \& Micoletzky, H. 1911, Convoluta pelagica, n. sp. und Monochoerus ¡llardatus, etc. Zool. Anz. v. 37, p. 481-486. Leipzig. 1911a, Ueber zwei neue pelagische Acölen des Golfes von Triest. Zeitschr. wiss. Zool. v. 98, p. 381-429 t. 19-20. Leipzig. Luther,A. 1904, Die Eumesostominen. Zeitschr. wiss. Zool. v. 77, p. 1-273 t. 1-9. Leip- 
zig. 1907, Ueber die systematische Stellung der Rhabdocoelen-Familie Catenulidæ 8. str. (=Stenostomidæ Vejd.). Zool. Anz. v. 31, p. 718-723. Leipzig. 1912, Studien über Acöle Turbellarien aus dem Finnischen Meerbusen. Acta Soc. Fauna Flora Fenn. v. 36 no. 5, p. 1-60 t. 1-2. Helsingfors. 1947, Untersuchungen an rhabdocoelen Turbellarien. VI. Macrostomiden aus Finnland. Acta Zool. Fenn. no. 49, p. 1-40. Helsingforsiæ. 1948, Untersuchungen an rhabdocoelen Turbellarien. VII. Ueber einige marine Dalyellioida. VIII. Beiträge zur Kenntnis der Typhloplanoida. Acta Zool. Fenn. no. 55, p. 1-122. Helsingforsiæ. Marcus, E. 1945, Sôbre Catenulida brasileiros. Bol. Fac. Fil. Ci. Letr. Univ. S. Paulo, Zoologia no. 10, p. 3-133 t. 1-16. São Paulo. 1945a, Sôbre Microturbellários do Brasil. Com. Zool. Mus. Montevideo v. 1 no. 25, p. 1-74 t. 1-11 ; summary p. (1-4). Montevideo. 1946, Sôbre Turbellaria brasileiros. Bool. Fac. Fil. Ci. Letr. Univ. S. Paulo, Zoologia no. 11, p. 5-250 t. 1-31. São Paulo. 1947, Turbelários marinhos do Brasil. Bol. Fac. Fil. Ci. Letr. Univ. S. Paulo, Zoologia no. 12, p. 99-215. t. 1-21. São Paulo. 1948, Turbellaria do Brasil. Bol. Fac. Fil. Ci. Letr. Univ. S. Paulo, Zoologia no. 13, p. 111-243 t. 1-20. São Paulo. 1949, Turbellaria Brasileiros (7). Bol. Fac. Fil. Ci. Letr. Univ. S. Paulo, Zoologia no. 14, p. 7-156 t. 1-22. São Paulo. Maristo, L. 1938, Beiträge zur Kenntnis der Monocelidinen. Ann. Soc. Zool. Bot. Fenn. Vanamo. v. 6 no. 3, p. I-VI, 1-69 t. 1. Helsinki. Meisenheimer, J.1921, Geschlecht und Geschlechter im Tierreiche. v. 1, XIV + 896 p. 737 fig. Jena (Fischer). Meixner, A. 1907, Polycladen von der Somaliküste nebst einer Revision der Stylochinen. Zeitschr. wiss. Zool. v. 88, p. $385-498$ t. 25-29. Lẹipzig. Meixner, J. 1923, Ueber die Kleptokniden von Microstomum lineare (Müll.). Biol. Zentralbl. v. 43, p. 559-573. Leipzig. 1924, Studien zu einer Monographie der Kalyptorhynchia und zum System der Turbellaria Rhabdocoela. Zool. Anz. v. 60, p. 1-29 (paginação da separata). Leipzig. 1925, Beitrag zur Morphologie und zum System der Turbellaria Rhabdocoela. I. Die Kalyptorhynchia. Zeitschr. Morphol. Oek. v. 3, p. 255-343 t. 2-3. Berlin. 1926, Beitrag. II. Ueber Typhlorhynchus nanus, etc. Zeitschr. Morphol. Oek. v. 5, p. 577-624. Berlin. 1928, Aberrante Kalyptorhynchia (Turbellaria Rhabdocoela) aus dem Sande der Kieler Bucht (I). Zool. Anz. v. 77, p. 229-253. Leipzig. 1928a, Der Genitalapparat der Tricladen, etc. Zeitschr. Morphol. Oek. v. 11, p. 570-612. Berlin. 1929, Morphologisch-ökologische Studien an neuen Turbellarien aus dem Meeressande der Kieler Bucht. Zeitschr. Morphol. Oek. v. 14, p. 765-791. Berlin. 1930, veja: Stummer-Traunfels \& Meixner. 1938, Turbellaria (Strudelwürmer). G. Grimpe, Tierwelt Nord \& Ostsee pars IVb, p. 1-146, 100 fig. Leipzig (Akad. Verlagsges.). 1943, Ueber die Umbildung einer Turbellarienart nach Einwanderung ins Süsswasser. Internat. Rev. ges. Hydrobiol. v. 43, p. 458-468. Leipzig. Midelburg, A. 1908, Zur Kenntnis der Monocelididæ. Zeitschr. wiss. Zool. v. 89, p. 81-108 t. 6. Leipzig. Milne, A. 1940, Some ecological aspects of the intertidal area of the estuary of the Aberdeenshire Dee. Transact. R. Soc. Edinb. v. 40 pt. 1 no. 4, p. 107-139 t. 1-2. Edinburgh. Mortensen, Th. 1925, An Apparatus for Catching the Micro-Fauna of the Sea-Bottom. Publ. Mus. Köbenhavn no. 2. Vidensk. Meddel. Dansk Naturh. Foren. v. 80, p. 445-451. Köbenhavn. Nassonov, N. 1930, Vertreter der Familie Graffillidæ (Turbellaria) des Baikalsees. Bull. Ac. Sci. U. R. S. S., Cl. Sci. physicomath. 1930, p. 727-738. Leningrad. Nuttycombe, J. W. \& Waters, A. J. 1938, The American Species of the Genus Stenostomum. Proc. Am. Phil. Soc. v. 79, p. 213-301 t. 1-8. Philadelphia. Örsted, A. S. 1843, Forsög til en ny Classification af Planarierne, 
etc. Kröyer's Naturh. Tidsskr. v. 4, p. 519-581. Kjöbenhavn. 1845, Fortegnelse over Dyr, samlede i Christianiafjord ved Dröbak, etc. Kröyer's Naturh. Tidsskr. ser. 2 v. 1, p. 415-419. Kjöbenhavn. Palombi, A. 1924, Policladi Pelagici. Raccolte Planctoniche

"Liguria" v. 3, p. 1-28 t. 1-2. Firenze. 1928, Report on the Turbellaria (Cambridge Exp. Suez Canal 1924). Transact. Zool. Soc. London v. 22, p. 579-631 t. 1. London. 1931, Turbellari della Nuova Guinea. Res. Sci. Voy. Indes Nérland. (Mém. Mus. R. Hist. Nat.) v. 2 fasc. 8, p. 1-14 t. 1. Bruxelles. 1938, Turbellari del Sud Africa. Arch. Zool. Ital. v. 25, p. 329-383 t. 9. Torino. Parker, T. J. \& Haswell, W. A. 1940, A TextBook of Zoology. 6. ed. v. 2, XXIII + 758 p. 656 fig. London (MacMillan). Pearse, A. S. 1938, Polyclads of the East Coast of North America. Proc. U. S. Nat. Mus. v. 86, no. 3044, p. 67-98. Washington, D. C. Pease, W. H. 1860, Descriptions of new species of Planaridæ collected in the Sandwich Islands. Proc. Zool. Soc. London v. 28, p. 37-38 t. 70. London. Peebles, F. 1915, A description of three Acoela from the Gulf of Naples. Mitteil. Zool. Stat. Neapel v. 22, p. 291-312 t. 10. Berlin. Plehn, M. 1896, Neue Polycladen, gesammelt von Herrn Capitän Chierchia . Vettor Pisani, etc. Jen. Zeitschr. Naturw. v. 30, p. 137-176 t. 8-13. Jena. 1896a, Die Polycladen der Planktonexpedition. Ergebn. Plankt. Exp. v. 2. H. f., p. 1-13. Kiel \& Leipzig (Lipsius \& Tischer). 1898, Polycladen von Ternate. Abhandl. Senckenb. Ges. v. 24, p. 145-146. Frankfurt a. M. Quatrefages, A. de 1845, Etudes sur les types inférieurs de l'embranchement des Annelés. Ann. Sci. nat. sér. 3 Zool. v. 4, p. 129-184 t. 3-7. Paris. Reisinger, E. 1924, Zur Anatomie von Hypotrichina, etc. Zool. Anz. v. 60, p. 137-149. Leipzig. 1924a, Die terricolen Rhabdocoelen Steiermarks. Zool. Anz. v. 59, p. 1-45 (paginação da separata). Leipzig. 1924b, Zur Turbellarienfauna der Ostalpen. Zool. Jahrb. Syst. v. 49, p. 229-298 t. 1. Jena. 1926, Zur Turbellarienfauna der Antarktis. D. Südp. Exp. v. 18 Zool. v. 10, p. 415-462. Berlin \& Leipzig (W. de Gruyter), 1929, Zum Ductus genito-intestinalis-Problem, etc. Zeitschr. Morphol. Oek. v. 16 (1930) fasc. 1-2 (1929), p. 49-73. Berlin. 1934, Turbellaria. Nord. Plankton, p. X 43-X 56. Kiel \& Leipzig (Lipsius \& Tischer). 1935, Ergebnisse einer .. Reise in Grönland. 6. Proporoplana jenseni, nov. gen., etc. Vidensk. Meddel. Dansk Naturh. Foren. v. 98, p. 243-259. Köbenhavn. Remane, A. 1926, Morphologie und Verwandtschaftsbeziehungen der aberranten Gastrotrichen. I. Zeitschr. Morphol. Oek. v. 5, p. 625-754. Berlin. Riedel, G. 1932, Ergebnisse einer Reise Grönland. 3. Macrostomida. 4. Dalyelliidæ. Vidensk. Meddel. Dansk Naturh. Foren. v. 93, p. 33107 t. 1-4. Köbenhavn. Ritter-Záhony, R. v. 1908, Beitrag zur Anatomie von Allostoma monotrochum Graff. Mitt. Naturw. Verein Steiermark v. 44 (Jahrg. 1907), p. 147-155 t. 1. Graz. Ruebush, T. K. 1935, The occurrence of Provortex affinis Jensen in the United States. Zool. Anz. v. 111, p. 305-308. Leipzig. 1938, A comparative study of the Turbellarian Chromosomes. Zool. Anz. v. 122, p. 321-329. Leipzig. Ruebush, T. K. \& Hayes, W. J., Jr. 1939, The genus Dalyellia in America. II. Zool. Anz. v. 128, fasc. 5-6, p. 136-152. Leipzig. Schmarda, L. K. 1859, Neue wirbellose Thiere. v. 1, 1.a metade (Turbellaria, Rotatoria, Annelida), XVIII + 66 p. 15 t. Leipzig (Engelmann). Schmidt, E. O. 1848, Die rhabdocoelen Strudelwürmer des süssen Wassers. 66 p. 6 t. Jena (Friedrich Mauke). Sekera, E. 1911, Studien über Turbellarien. S..Ber. K. Böhm. Ges. Wissensch. II. Classe no. 13, p. 1-38 t. 1. Prag. Southern, R. 1936, Turbellaria of Ireland. Pr. R. Irish Acad. v. 43 Sect. B no. 5, p. 43-72. Dublin. Steinböck, O. 1931, Marine Turbellaria. Zoology of the Faroes, part 8, p. 1-26. Copenhagen. 1932, Die Tur- 
bellarien des arktischen Gebietes. Fauna Arct. v. 6, p. 295-342. Jena (Fischer). 1933, Die Turbellarienfauna der Umgebung von Rovigno. Thalassia v. 1 no. 5, p. 1-33. Jena. 1938, Marine Turbellaria. Zoology of Iceland v. 2 part 9, p. 1-26. Copenhagen \& Reykjavik. Steinböck, O. \& Reisinger, E. 1930, Ergebnisse einer Reise in Grön.land 1926. Vidensk. Meddel. Dansk Naturh. Foren. v. 90, p. 13-43. Köbenhavn. Stirewalt, M. A., Ferguson, F. F., \& Kepner, W. A. 1942, Two new Turbellaria Pregermarium. Journ. Elisha Mitchell Sci. Soc. v. 58, p. 69-78 t. 12. Chapel Hill, N. C. Stirewalt, M. A., Kepner, W. A., \& Ferguson, F. F. 1940, A new Turbellarian worm from Beaufort, N. C. Journ. Elisha Mitchell Sci. Soc. v. 56, p. 123-133 t. 2-3. Chapel Hill, N. C. Stummer-Traunfels, R. v. 1933, Ergänzende Untersuchungen, etc., Polycladida. Bronn's Kl. Ordn. v. 4 Abt. 1 c, fasc. 179, p. 3485-3596 t. 1. Leipzig (Akad. Verlagsges.). Stummer-Traunfels, R. v., \& Meixner, J. 1930, V. Nachtrag zum Literaturverzeichnis. Bronn's Kl. Ordn. v. 4 Abt. 1 c, fasc. 178, p. 3371-3484. Leipzig (Akad. Verlagsges.). Van Beneden, E. 1870, Etude zoologique et anatomique du genre Macrostomum, etc. Bull. Acad. R. Belgique sér. 2 v. 30 no. 8, p. 1-20 (114-133 do Bull.) 1 t. Bruxelles. Vejdovsky, F. 1882, Thierische Organismen der Brunnenwässer von Prag. Turbellaria p. 50-60. Prag. Verrill, A. E. 1900, Additions to the Turbellaria, etc., of the Bermudas. Transact. Connect. Acad. Arts Sci., v. 10, p. 595-672 t. 70. New Haven Conn. 1901, Additions to the Fauna of the Bermudas, etc. Transact. Connect. Acad. Arts Sci. v. 11 (1901-1903) part 1 (1901-1902), p. 15-62 t. 1-9. (Turbellaria : t. 5). New Haven, Conn. Wagner, F. v. 1890, Zur Kenntnis der ungeschlechtlichen Fortpflanzung von Microstoma. Zool. Jahrb. Anat. v. 4 (1891) fasc. 3 (1890), p. 349-432 t. 22-25. Jena. 1891, Zur Kenntnis des Baues der Haftpapillen von Microstoma lineare Örst. Zool. Anz. 14. Jahrg. no. 373, p. 1-4 (da separata). Leipzig. Weiss, A. 1910, Beiträge zur Kenntnis der Australischen Turbellarien. II. Zeitschr. wiss. Zool. v. 96, p. 336-372 t. 14-15. Leipzig. Westblad, E. 1935, Pentacoelum fucoideum m., ein neuer Typ der Turbellaria metamerata. Zool. Anz. v. 111, p. 65-82. Leipzig. 1937, Die Turbellariengattung Nemertoderma Steinböck. Acta Soc. Fauna Flora Fenn. no. 60, p. 45-89. Helsingforsiæ. 1940, Studien über skandinavische Turbellaria Acoela. I. Ark. Zool. v. 32 A no. 20, p. 1-28 t. 1-2. Stockholm. 1942, Studien II. Ark. Zool. v. 33 A no. 14, p. 1-48 t. 1-3. Stockholm. 1945, Studien III. Ark. Zool. v. 36 A no. 5, p. 1-56 t. 1-4. Stockholm. 1946, Studien . . IV., Ark. Zool. v. 38 A no. 1, p. 1-56 t. 1-3, f. 1 A-42 D (16 t.). Stockholm. 1948, Studien V Ark. Zool. v. 41 A no. 7, p. 1-82 t. 1. Stockholm. Woodworth, W. M. 1898, Some Planarians of the Great Barrier Reef of Australia. Bull. Mus. Comp. Zool. Harvard Coll. v. 32, p. 63-67, 1 t. Cambridge, Mass. Yeri, M. \& Kaburaki, T. 1918, Description of some Japanese Polyclad Turbellaria. J. Coll. Sci. Imp. Univ. v. 39 no. 9, p. 1-54 t. 1-2. Tokyo. 


\section{ESTAMPA I}

\section{Haploposthia microphoca, sp. n.}

Fig. 1 - Verme vivente; vista dorsal.

Fig. 2 - Corte mediano, combinado.

a, átrio masculino. b, bôca. c, cérebro. e, estatocisto. f, desembocadura do órgão frontal. g, glândulas do órgão frontal. m, células sensoriais de Luther. n, endocício. o, zona germinativa ovariotesticular. p, pigmento na desembocadura das glândulas. frontais. $\mathrm{r}$, glândula rabditógena. $\mathrm{s}$, vesícula seminal. $\mathrm{t}$, poro masculino.

Paraproporus xanthus, sp. n.

Fig. 3 - Corte mediano, combinado.

Fig. 4 - Corte tangencial do epicício.

Fig. 5 - Corte mediano da região posterior do corpo.

a, átrio masculino. b, bôca. c, cérebro. d, diatomáceas no endocício. e, estatocisto. $\mathrm{f}$, órgão frontal. g, glândulas de secreção mucosa. h, epicício. i, endocício. j, ectocício. $\mathrm{k}$, músculos dorso-ventrais (parênquimáticos). l, musculatura cutânea longitudinal. m, musculatura cutânea anelar. o, ovócito com células foliculares. p, bastonetes peniais. $s$, vesícula seminal. $t$, testículo.

Convoluta divæ, sp. $\mathrm{n}$.

(Também Estampa IV, Figs. 21-23)

Letras veja Estampa IV

Fig. 6 - Verme vivente ; vista dorsal. As glândulas (g) do gonóporo acrescentadas. com auxílio de cortes horizontais.

Fig. 7 - Rabditos vistos em corte tangencial. 


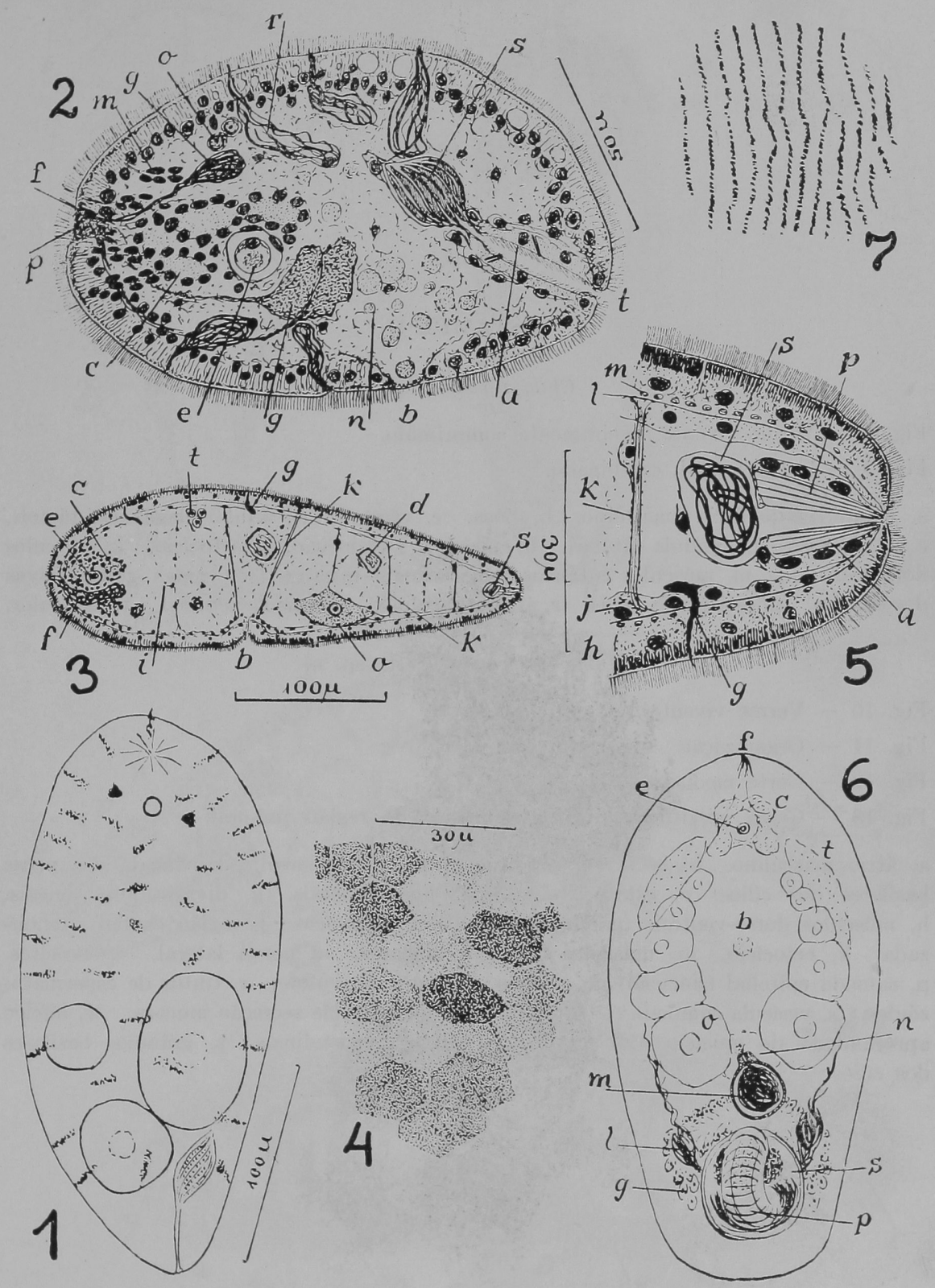




\section{ESTAMPA II}

\section{Childia pansa, sp. n.}

Fig. 8 - Verme vivente, ligeiramente comprimido.

Fig. 9 - Corte sagital, combinado.

a, glândulas do átrio masculino. b, bôca. c, cérebro. d, células flageladas tácteis. e, estatocisto. g, glândula cutânea. h, epicício. i, endocício. j, ectocício. k, músculos dorso-ventrais. $\mathrm{m}$, músculos cutâneos longitudinais internos. o, zonas germinativas dos ovários. p, estilete do penis. r, átrio masculino. $\mathrm{s}$, vesícula seminal. $\mathrm{t}$, testículos.

Kuma brevicauda, g. n., sp. n.

Fig. 10 - Verme vivente, em vista dorsal.

Fig. 11 - Organização ; vista ventral.

Fig. 12 - Corte mediano.

Fig. 13 - Corte longitudinal do integumento da região pré-oral.

a, átrio masculino. b, bôca. c, cérebro (gânglios superiores). d, camada das peças basilares dos cílios. e, estatocisto. f, glândulas frontais. g, divaricadores bucais. $\mathrm{h}$, músculos dorso-ventrais (parenquimáticos). i, endocício. j, região caudal vacuolizada. $\mathrm{k}$, ectocício. $\mathrm{m}$, músculos cutâneos anelares. $\mathrm{n}$, nervo lateral. o, ovócitos. p, camada epitelial (sincicial) do epicício. q, poro masculino. r, tratos de espermatozóides. s, vesícula seminal. t, testículos. u, glândula de secreção mucosa. w, núcleo aprofundado do epicício. y, músculos cutâneos longitudinais. z, grânulos basilares dos cílios. 


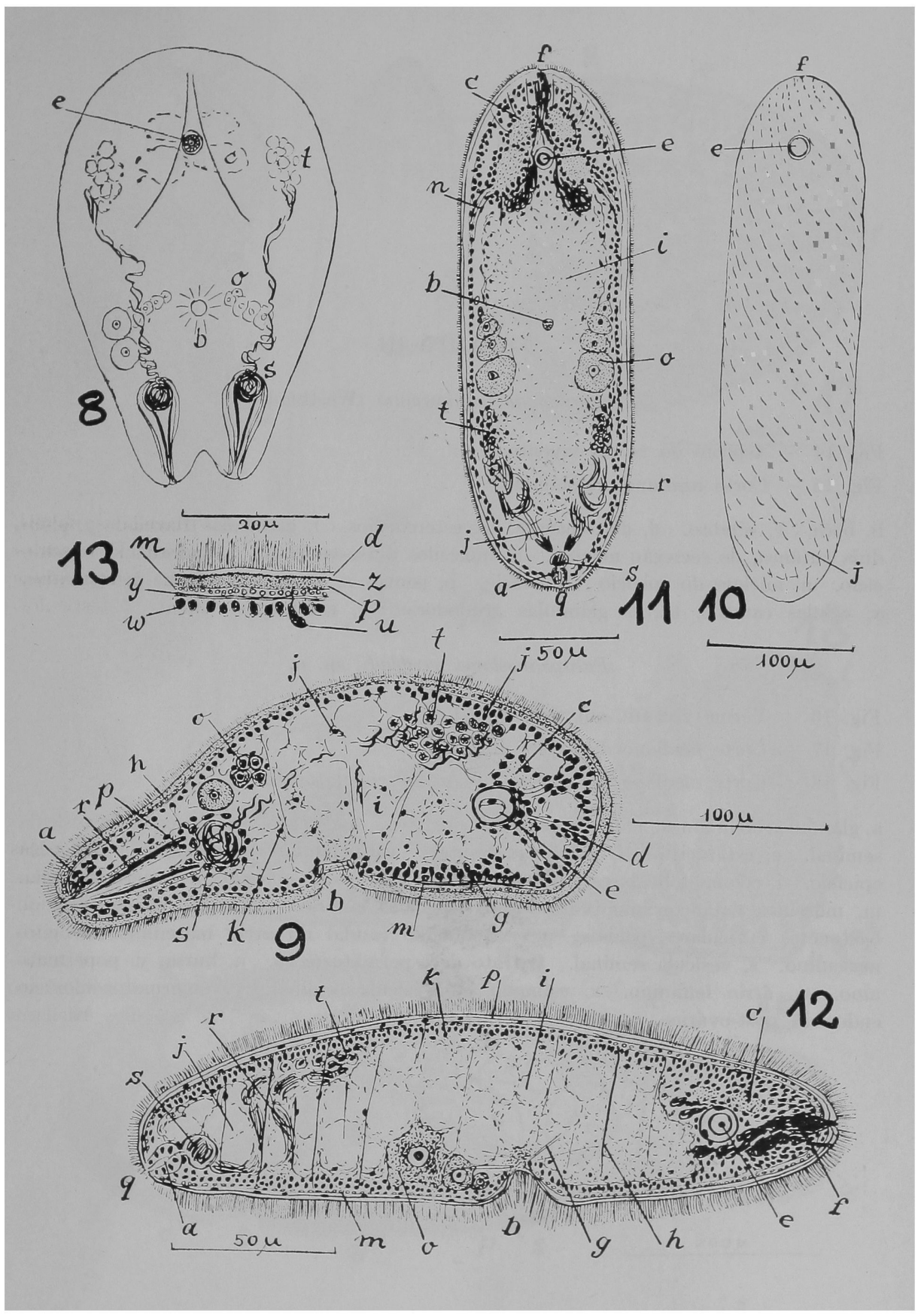




\section{ESTAMPA III}

Mecynostomum tenuissimum (Westblad)

Fig. 14 - Aspecto do verme vivente.

Fig. 15 - Corte mediano, combinado.

b, bôca. c, cérebro. d, diatomáceas. e, estereocílios. f, glândulas frontais. g, glândula cutânea, de secreção mucosa. h, músculos dorso-ventrais. i, endocício. k, ectocício. $\mathrm{n}$, núcleos do epicício. o, ovário. $\mathrm{p}$, penis. $\mathrm{s}$, vesícula seminal. $\mathrm{t}$, testículos. $\mathrm{x}$, células caudais, talvez glândulas grudadoras. $\mathrm{y}$, estatocisto.

\section{Paraphanostoma uestbladi, sp. n.}

Fig. 16 - Verme vivente, em vista dorsal.

Fig. 17 - Corte mediano da região antcrior.

Fig. 18 - Corte mediano da região dos órgãos copulatórios.

a, glândulas do órgão copulador masculino. b, bôca. c, cérebro. d, músculos da vesícula seminal. e, estatocisto. f, glândulas frontais. $\mathrm{g}$, glândulas cưtâneas. h, epitélio do epicício. i, células foliculares. i, ectocício. k, núcleos do epicício. l, espermatogônia. m, músculos cutâneos longitudinais. n, músculos cutâneos anelares. o, ovócito. p, bastonetes cuticulares peniais. q, extremidade caudal do átrio masculino. r, poro masculino. s, vesícula seminal. t, trato de espermatozóides. $\mathrm{u}$, bursa. $\mathrm{v}$, poro feminino. w, átrio feminino. $\mathrm{x}$, esfíncter da vesícula seminal. $\mathrm{y}$, espermatozóides no endocício post-ovárico. z, duto espermátioo. 

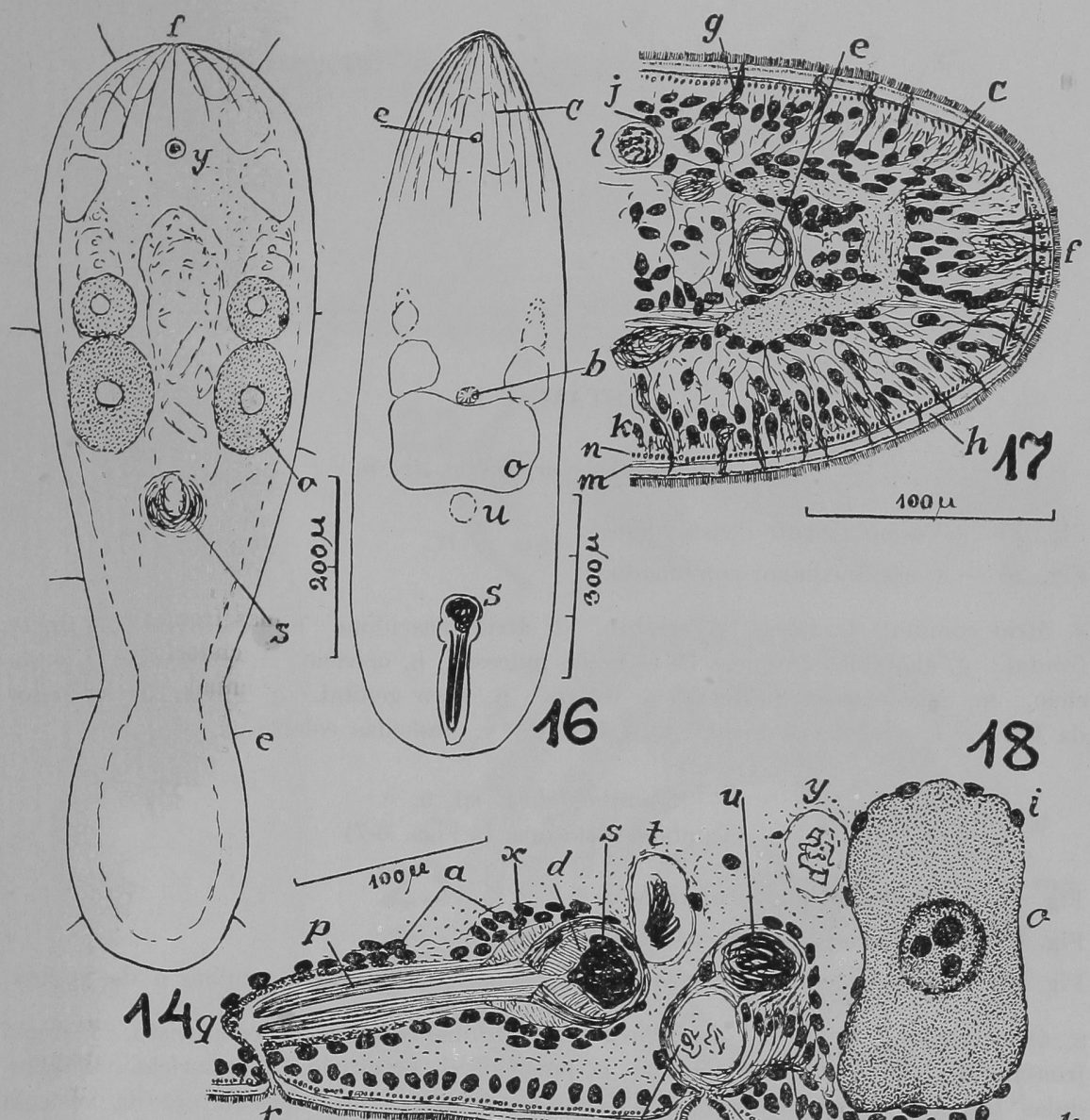

- $000000-1 / 4$
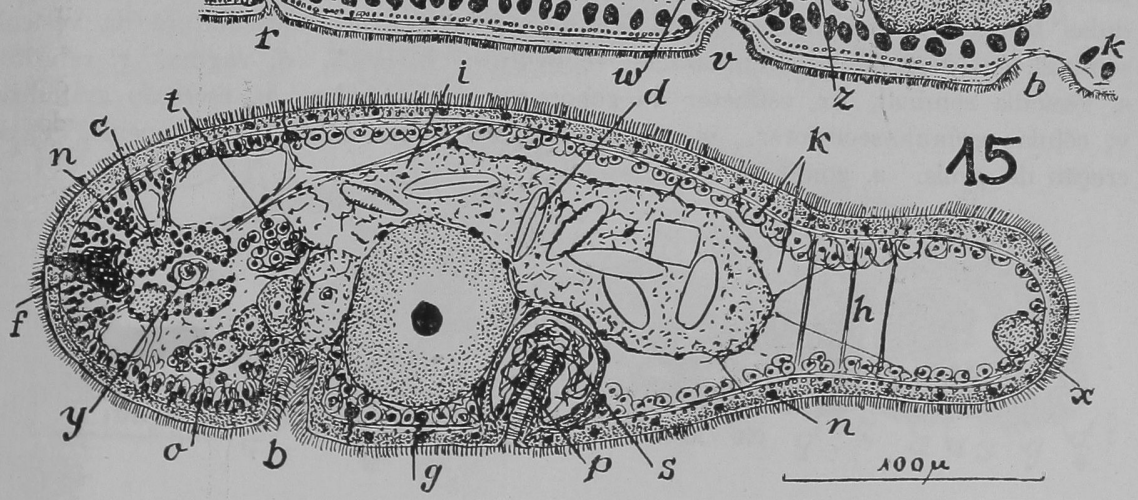


\section{ESTAMPA IV}

\section{Aphanostoma orphinum, sp. $\mathrm{n}$.}

Fig. 19 - Verme vivente ; vista dorsal.

Fig. 20 - Corte mediano, combinado.

a, átrio comum. b, bôca. c, cérebro. d, átrio masculino. c, estatocisto. f, órgão frontal. g, glândulas cutâneas de secreção mucosa. h, epicício. i, endocício. j, ectocício. $\mathrm{m}$, musculatura cutânea. o, ovário. p, poro genital. q, bursa. r, apêndice da bursa. s, vesícula seminal. $\mathrm{t}$, testículos. v, vesículas coloríficas.

Convoluta divæ, sp. n.

(Também Estampa I, Figs. 6-7)

Fig. 21 - Corte mediano, combinado.

Fig. 22 - Palhetas da bursa de vários animais.

Fig. 23 - Corte mediano, combinado, do órgão copulatório masculino e da vagina.

a, átrio comum. b, bôca. c, cérebro. d, glândulas caudais. e, estatocisto. f, órgão frontal. g, glândulas do gonóporo. h, epicício. i, endocício. j, ectocício. $\mathrm{k}$, glândulas bucais. l, vesículas seminais falsas. $\mathrm{m}$, bursa. $\mathrm{ms}$, musculatura da vesícula seminal. $\mathrm{n}$, vesícula parenquimática. o, ovários. $\mathrm{p}$, penis. $\mathrm{q}$, vagina. $\mathrm{r}$, rabditos. $\mathrm{s}$, vesícula seminal. sr, esfíncter do gonóporo. t, testículos. u, secreção granulosa. $\mathrm{v}$, células grânulo-secretoras. w, musculatura do penis. $\mathrm{x}$, epitélio do penis. $\mathrm{y}$, secreção do penis. $\mathrm{z}$, gonóporo. 


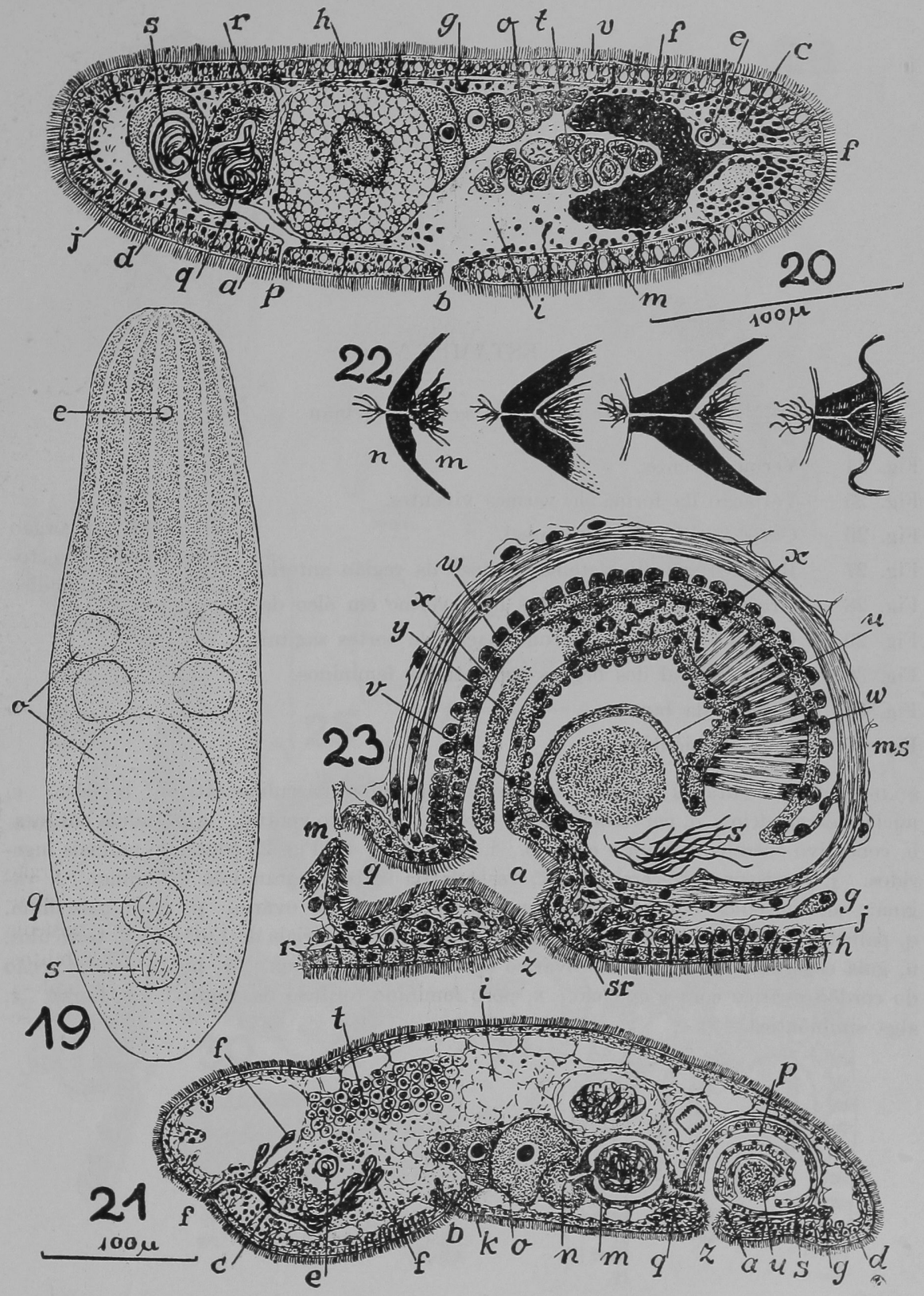




\section{ESTAMPA V}

\section{Amphiscolops sargassi Hyman}

Fig. 24 - Verme vivente.

Fig. 25 - Variação da forma de vermes viventes.

Fig. 26 - Corte sagital da pele dorsal.

Fig. 27 - Reconstrução do sistema nervoso da região anterior.

Fig. 28 - Órgãos reprodutivos vistos num verme em óleo de cravo.

Fig. 29 - Órgãos copulatórios ; combinação de cortes sagitais.

Fig. 30 - Vista ventral dos órgãos copulatórios femininos.

Fig. 31 - Palheta da bursa.

Fig. 32 - Alga simbiôntica.

a, musculatura cutânea anelar. am, órgão copulador masculino (átrio). b, bôca. c, núcleos do epicício. d, nervo dorsal. e, cérebro. f, nervo ventral. g, glândula cutânea. h, conectivo entre comissura e cérebro. i, endocício ; na Fig. 28 contendo animais ingeridos. $\mathrm{j}$, comissura pré-cerebral. $\mathrm{k}$, vesícula da secreção granulosa e seminal. l, vagina. $\mathrm{m}$, músculos dorso-ventrais. $\mathrm{n}$, nervo lateral. o, ovário. $\mathrm{p}$, poro masculino. q, palhetas da bursa. r, estroma ovárico. $\mathrm{s}$, órgãos sensoriais de Luther. $\mathrm{t}$, testículos. $\mathrm{u}$, guia espermático. $\mathrm{v}$, cordão ovárico formado pelo estroma. w, ponto de concreção do cordão ovárico com o epicício. x, poro feminino (orifício da vagina). y, bursa. z, alga simbiôntica. 


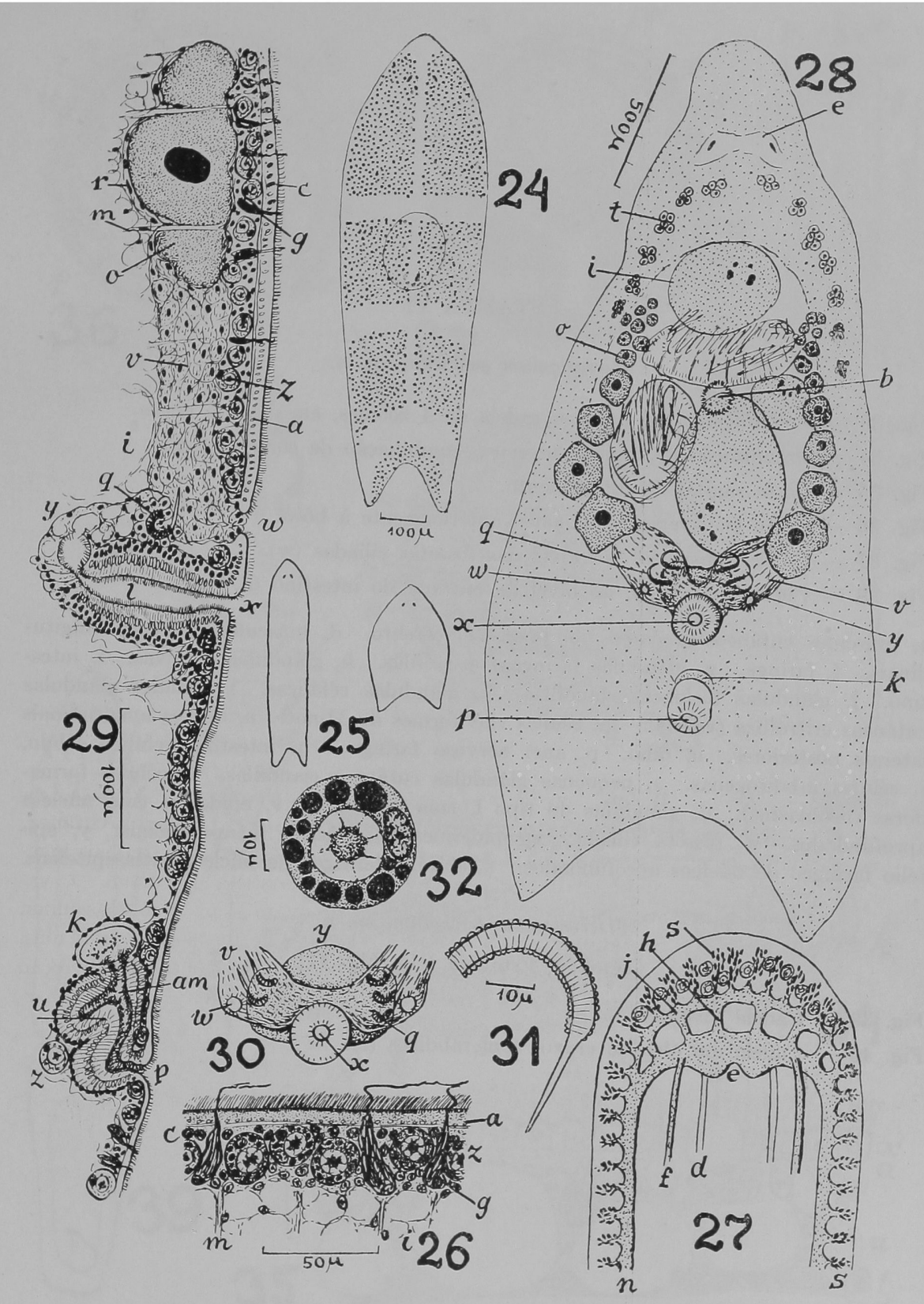




\section{ESTAMPA VI}

\section{Microstomum gabriellæ, sp. n.}

Fig. 33 - Preparação total de uma cadeia de 4 zoóides, em óleo de cravo.

Fig. 34 - Organização da região anterior ; combinação de cortes sagitais.

Fig. 35 - Corte sagital do integumento.

Fig. 36 - Corte transversal, um pouco anteriormente à bôca.

Fig. 37 - Corte transversal, ao nível das fossetas ciliadas (w).

Fig. 38 - Corte transversal, ao nível da entrada do intestino (i).

a, músculos cutâneos anelares. b, bôca. c, cérebro. d, músculos cutâneos longitudinais. f, faringe. g, glândulas faríngeas eritrófilas. h, glândulas adesivas. i, intestino. j, glândulas faríngeas cianófilas. k, glândulas cefálicas. l, grandes glândulas cutâneas eritrófilas (vazias). m, células claviformes de Minot. n, nervos longitudinais laterais posteriores. o, ôlho. $\mathrm{p}$, anel nervoso faríngeo. $\mathrm{q}$, intestino cefálico sólido. $r$, células rabditógenas. $s$, pequenas glândulas cutâneas cianófilas. $t$, células formadoras (neoblastos). u, glândulas do tipo 1 , com conteúdo. v, epiderme com núcleos aprofundados. $\mathrm{w}$, fosseta ciliada. $\mathrm{x}$, epiderme com núcleos intra-epiteliais. $\mathrm{y}$, epitélio faríngeo de núcleos aprofundados. z, epitélio faríngeo de núcleos intra-epiteliais.

Microstomum trichotum, sp. $\mathbf{n}$.

(Também Estampa VII, Fig. 41)

Fig. 39 - Cadeia vivente.

Fig. 40 - Cadeia em óleo de cravo, com rabditos (r). 


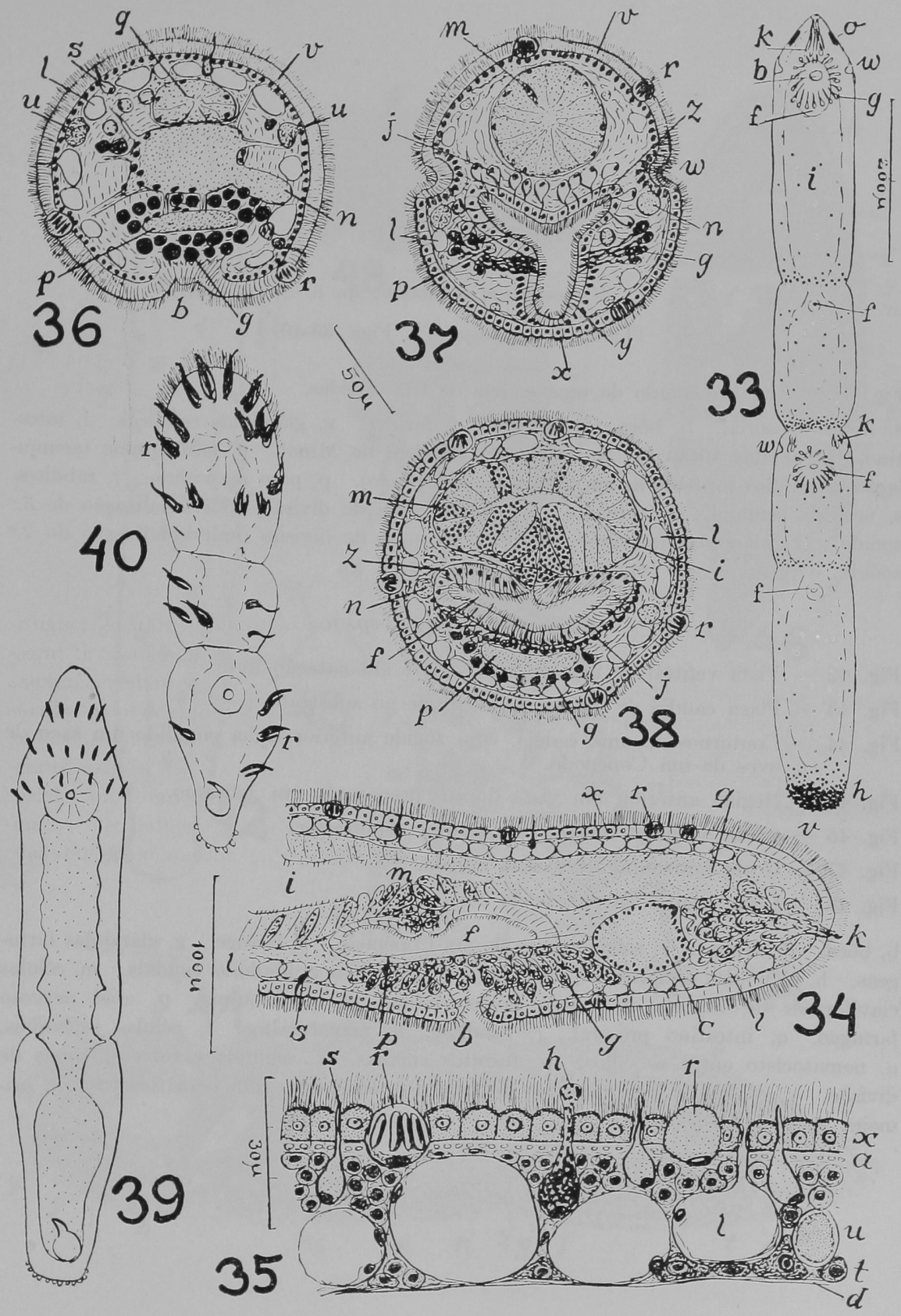




\section{ESTAMPA VII}

Microstomum trichotum, sp. n.

('Também Estampa VI, Figs. 39-40)

Fig. 41 - Corte mediano de uma cadeia de três zoóides.

a, botão sensorial. b, bôca. c, cérebro. f, faringe. g, glândulas cefálicas. i, intestino. $\mathrm{k}$, papilas adesivas. $\mathrm{m}$, células claviformes de Minot. $\mathrm{n}$, parênquima (acumulação de células formadoras em uma zona de divisão). p, poro masculino. r, rabditos. $\mathrm{s}$, vesícula seminal. $\mathrm{t}$, testículo. $\mathrm{x}$, segunda zona de divisão (individualização do $3 .^{\circ}$ zoóide). $y$, glândulas faríngeas. $\mathrm{z}$, primeira zona de divisão (individualização do $2 .^{\circ}$ zoóide, o posterior, já com os primórdios de c, f, g).

\section{Microstomum ulum, sp. n.}

Fig. 42 - Vista ventral de uma cadeia vivente em natação livre.

Fig. 43 - Placa caudal de um verme aderente ao substrato.

Fig. 44 - Contornos de uma cadeia, cujo zoóide anterior tinha engulido um saco de ovos de um Copépodo.

Fig. 45 - Região anterior, em vista dorsal ; preparação em bálsamo.

Fig. 46 - Corte mediano das regiões anterior e posterior.

Fig. 47 - Corte horizontal da fosseta ciliada.

Fig. 48 - Corte sagital da parede do corpo.

b, bôca. c, cérebro. e, saco de ovos de um Copépodo. f, faringe. g, glândulas faríngeas. h, glândulas cefálicas. i, intestino. k, glândulas grudadoras caudais. m, células claviformes de Minot. $\mathrm{n}$, nervo póstero-lateral. o, parênquima. $\mathrm{p}$, anel nervoso faríngeo. $q$, intestino pré-oral. $r$, rabditos. $s$, nematocistos. $t$, células sensoriais. $\mathrm{u}$, nematocisto entre os cílios. $\mathrm{w}$, fossetas ciliadas. $\mathrm{x}$, segunda e terceira zonas de divisão. y, células, talvez adesivas, do tronco ; em parte, com nematocistos. z, primeira zona de divisão. 

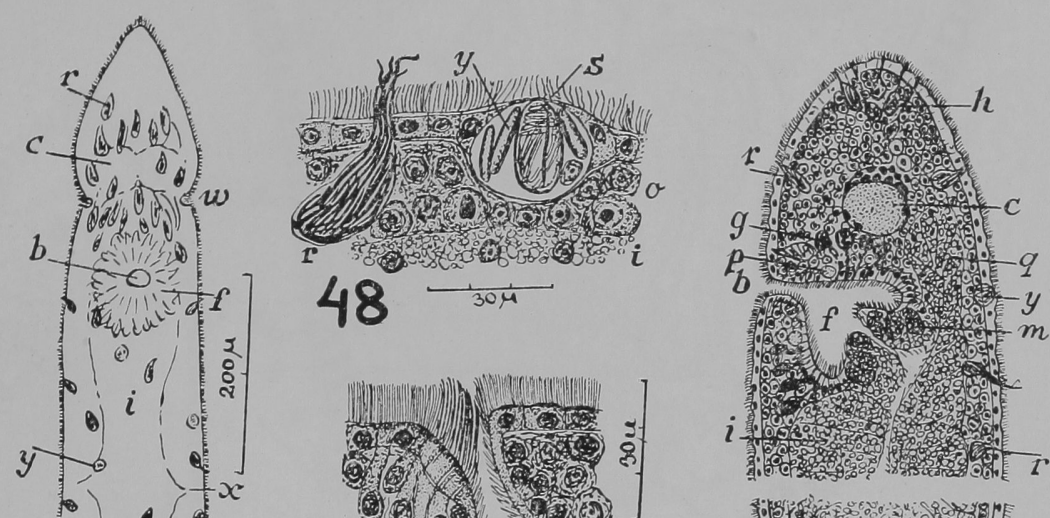

6.
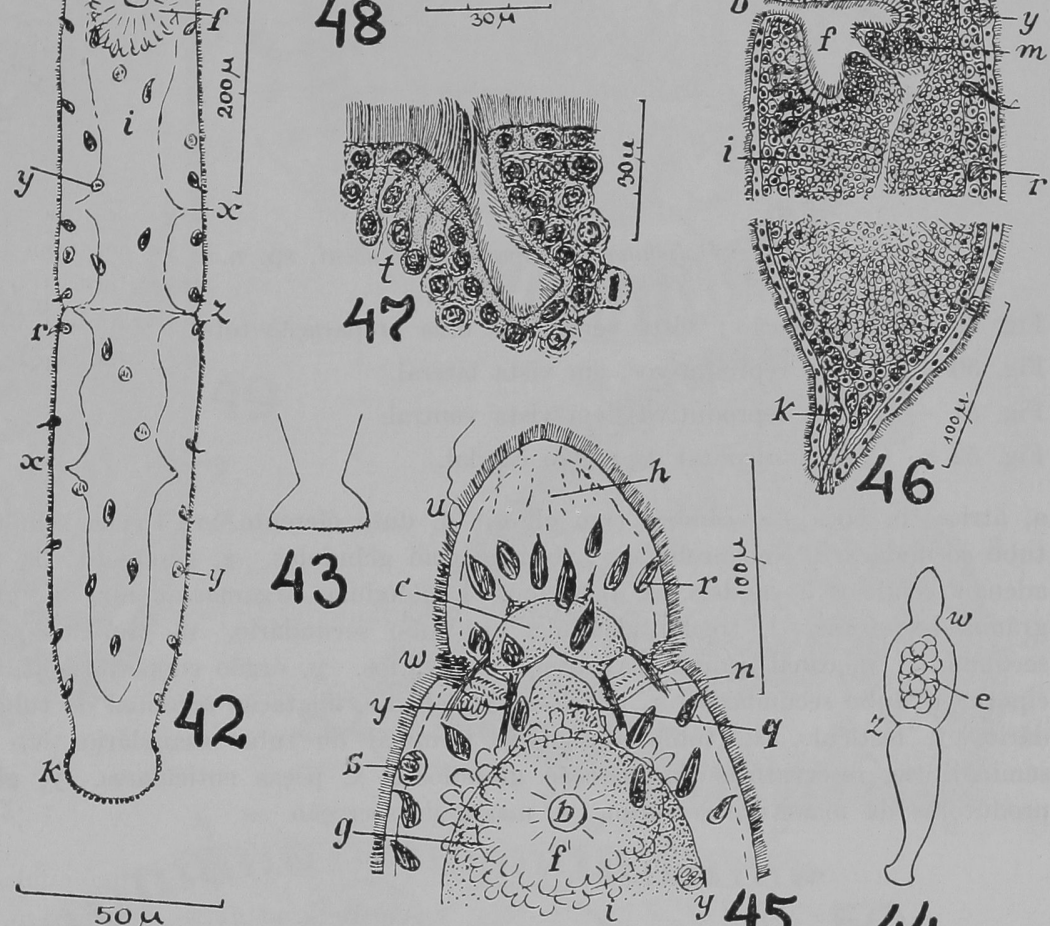

3
0
0
0
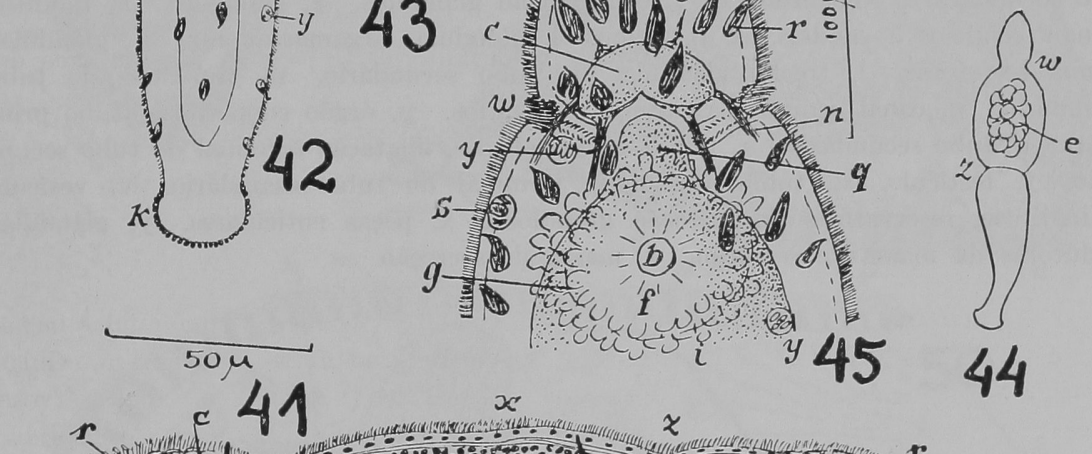

$x$
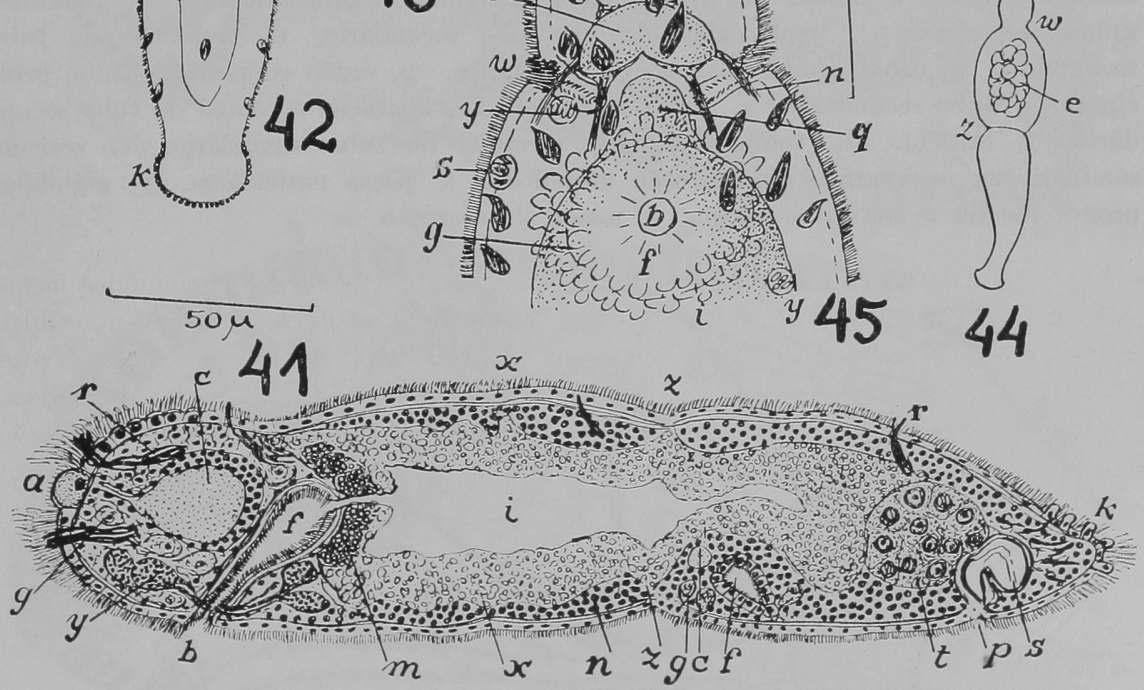


\section{ESTAMPA VIII}

Dolichomacrostomum mortenseni, sp. n.

Fig. 49 - Organização ; vista ventral de uma preparação total.

Fig. 50 - Órgãos reprodutivos, em vista lateral.

Fig. 51 - Órgãos reprodutivos, em vista ventral.

Fig. 52 - Corte horizontal da região caudal.

a, átrio. b, bôca. c, cérebro com olhos. d, duto eferente. e, trecho semilunar do tubo secundário ("Nebenrohr"). f, faringe com glândulas. g, gonóporo. h, rabditos adenais cefálicos e caudais. i, intestino. j, glândulas argamassadoras. k, glândulas grânulo-secretoras. 1, trecho glandular do tubo secundário. $\mathrm{m}$, músculos do tubo secundário. n, canal genital masculino. o, ovários. p, órgão copulatório (tubo principal). q, tubo secundário. r, rabditos dermais. s, dilatação terminal do tubo secu $n$ dário. $\mathrm{t}$, testículo. $\mathrm{u}$, tubinho anulado terminal do tubo secundário. $\mathrm{v}$, vesícula seminal. w, reservatório da secreção granulosa. $\mathrm{x}$, peças cuticulares. $\mathrm{y}$, glândulas produtoras da massa de secreção. $\mathrm{z}$, massa de secreção. 

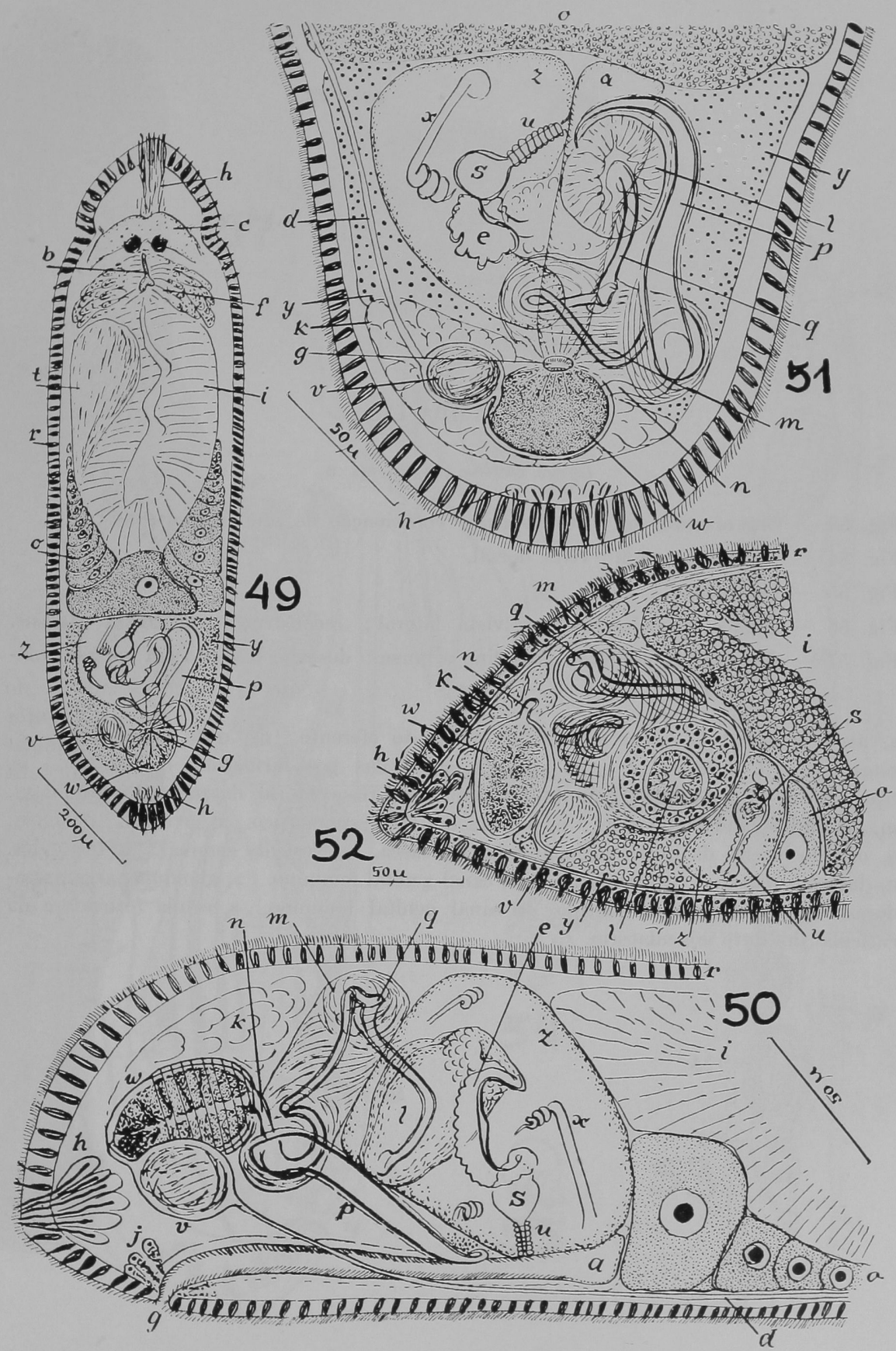


\section{ESTAMPA IX}

Lurus evelinæ, g. n., sp. n.

Fig. 53 - Organização, em vista ventral ; combinação de preparações totais.

Fig. 54 - Faringe evertida ; vista dorsal.

Fig. 55 - Estatocisto.

Fig. 56 - Orgãos reprodutivos, em vista lateral; reconstrução de cortes sagitais. Fig. 57 - Aparêlho copulatório masculino e bursa ; desenho baseado em vermes comprimidos.

a, átrio comum. b, bôca. c, cérebro. d, duto eferente. ds, duto espermático. e, estatocisto. f, faringe. g, gonóporo. h, glândulas post-faríngeas. i, intestino. ir, tubo bucal. j, glândulas grânulo-secretoras. $\mathrm{k}$, reservatório da secreção granulosa. $\mathrm{m}$, glândulas caudais adesivas. $\mathrm{n}$, palheta do duto espermático. o, ovários. p, bursa. $q$, orifício lateral da bursa. $r$, glândulas da casca. s, vesícula seminal. $t$, testículos. u, duto ejaculatório. v, vitelários. w, canal genital feminino. x, glândulas argamassadoras. $y$, dilatação ental (oótipo) do canal genital feminino. z, célula formadora da cutícula do duto ejaculatório. 


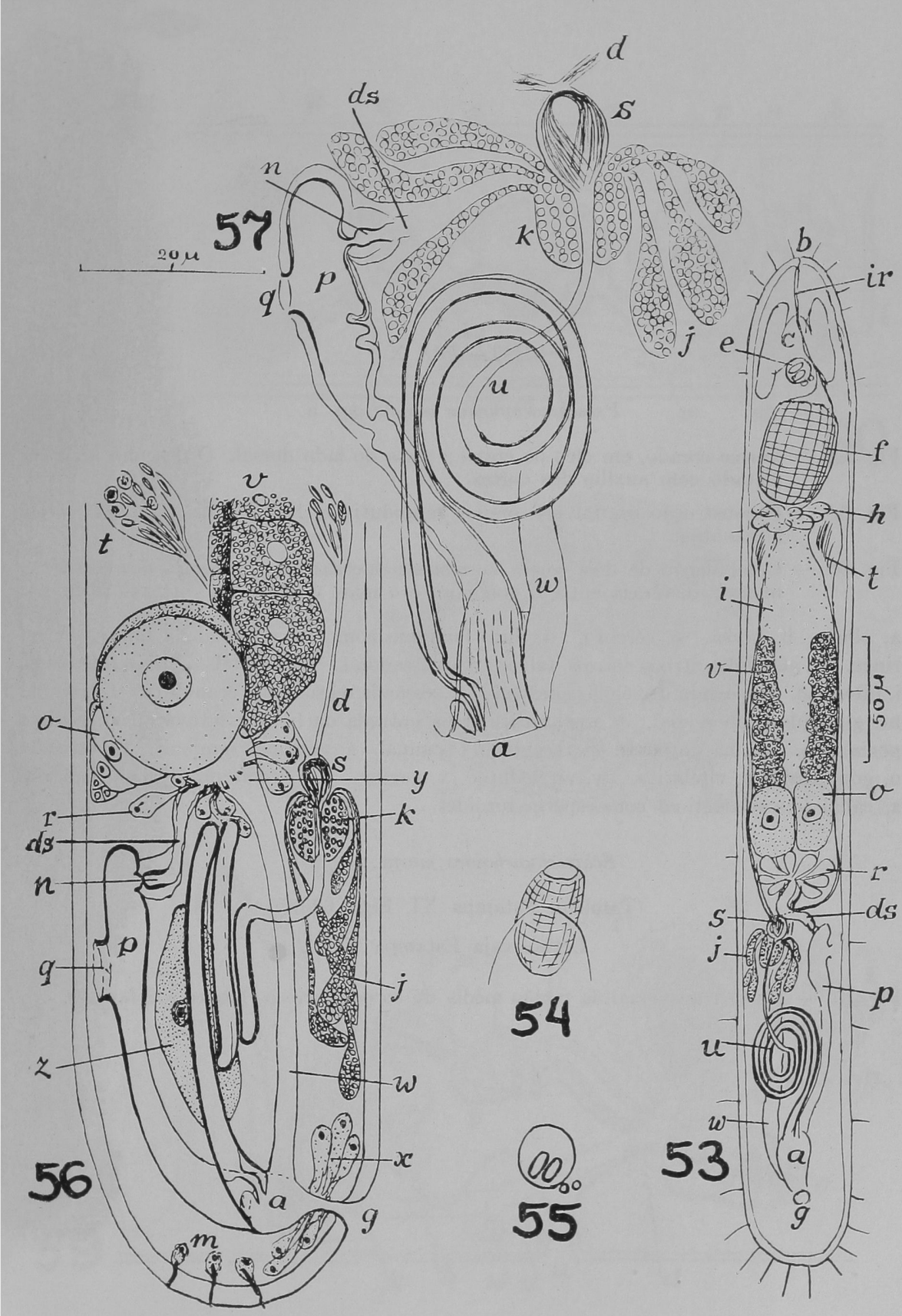




\section{ESTAMPA $\mathrm{X}$}

Proschizorhynchus atopus, sp. n.

Fig. 58 - Verme corado, em óleo de cravo ; vista do lado dorsal. O desenho foi completado com auxílio dos cortes.

Fig. 59 - Reconstrução sagital dos órgãos reprodutivos, baseada na série dos cortes horizontais.

Fig. 60 - Combinação de dois cortes horizontais successivos; grossura dos cortes : 8 micra ; distância entre o gonóporo e o mais ventral dos cortes : 32 micra.

a, olhos. b, bursa. c, cérebro. d, duto feminino comum. e, canal da bursa. f, faringe. g, glândulas atriais dorsais, talvez argamassadoras. h, glândulas atriais anteriores. $\mathrm{i}$, intestino. j, cintura de células adesivas. $\mathrm{k}$, vesícula da secreção granulosa. $\mathrm{l}$, tromba. m, glândula proboscidial. n, anel cuticular na entrada da bursa. o, ovário. p, estilete penial. q, bainha do penis. $\mathrm{r}$, receptáculo seminal. $\mathrm{s}$, vesículas seminais. $\mathrm{t}$, testículo. $\mathrm{u}$, gonópớo. $\mathrm{v}$, vitelários. $\mathrm{w}$, viteloduto. $\mathrm{x}$, vagina. $\mathrm{y}$, epitélio anfractuoso do átrio. z, canal bursa-intestinal com espermatozóides.

Schizorhynchoides martæ, sp. n.

(Também Estampa XI, Figs. 62-66)

Letras veja Estampa XI

Fig. 61 - Corte transversal da região média do corpo, entre o cérebro e a faringe. 

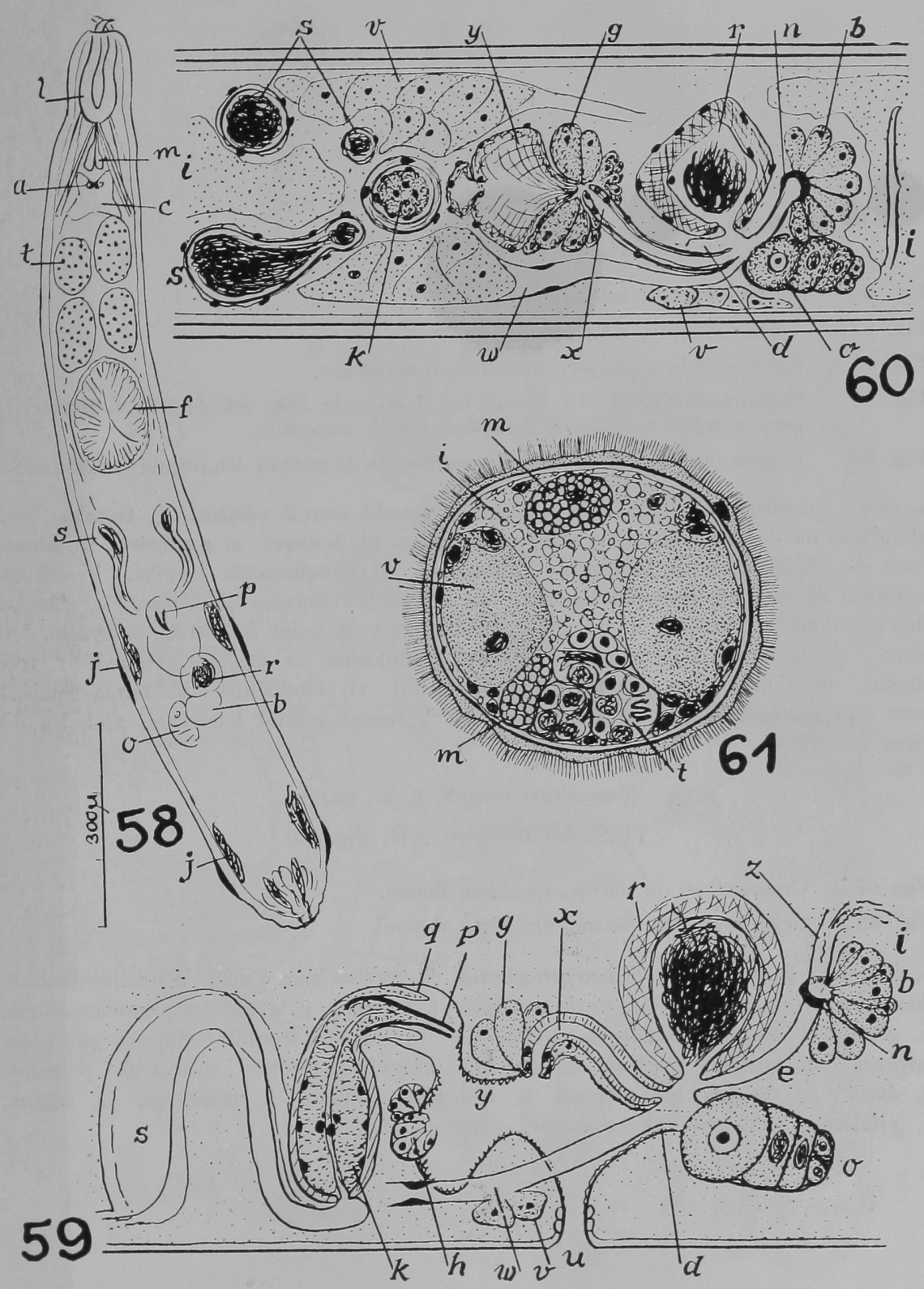


\section{ESTAMPA XI}

Schizorhynchoides martx, sp. n.

(Também Estampa X, Fig. 61)

Fig. 62 - Verme vivente, estendido.

Fig. 63 - Verme vivente, contraído.

Fig. 64 - Extremidade posterior, aderente ao substrato.

Fig. 65 - Organização geral; o verme foi desenhado com encurtamento artificial, para evitar uma figura demasiadamente comprida.

Fig. 66 - Ôrgãos reprodutivos ; desenho combinado de vermes comprimidos e cortados.

a, átrio. b, bôca. c, cérebro. d, bainha da tromba com 2 núcleos. e, tromba. ev, glândulas na desembocadura do duto espermático. f, faringe. g, gonóporo. h, almofada de células adesivas internas. i, intestino. $j$, retractores da tromba. $k$, células adesivas do anel de secreção basófila. m, células claviformes de Minot. $\mathrm{n}$, núcleos das glândulas da tromba, da vesícula granulorum e da bolsa do cirro. o, ovário. p, cirro. q, glândulas da tromba. $r$, vesícula granulorum. $\mathrm{s}$, vesícula seminal. $\mathrm{t}$, testículos. $\mathrm{u}$, vagina (duto vaginal). $\mathrm{v}$, vitelários. vi, viteloduto. $\mathrm{w}$, bursa seminal com espermatozóides. $\mathrm{x}$, duto espermático. $\mathrm{y}$, canal genital feminino. $\mathrm{z}$, bolsa do ('irro.

Rosmarium evelinæ, g. n., sp. n.

(Também Estampa XII, Fig. 69)

Fig. 67 - Organização do verme, em vista dorsal.

Fig. 68 - Organização do verme, em vista ventral.

a, glândulas da casca. b, orifício oro-genital. c, cérebro com olhos. d, trecho dilatado do esôfago. e, trecho tubuloso do esôfago. f, faringe. g, glândulas argamassadoras. $\mathrm{h}$, glândulas frontais (cefálicas). i, intestino. j, fosseta frontal (cefálica). k, bolsa faríngea. $\mathrm{m}$, bainha do penis. $\mathrm{n}$, glândulas grânulo-secretoras. $\mathrm{o}$, ovário. $\mathrm{p}$, penis. $\mathrm{q}$, átrio. $\mathrm{r}$, vesícula granulorum. $\mathrm{s}$, vesículas seminais. $\mathrm{t}$, testículos. $\mathrm{u}$, vagina. $\mathrm{v}$, vitelários. vi, ovovitelodutos. w, sulco ciliado. 


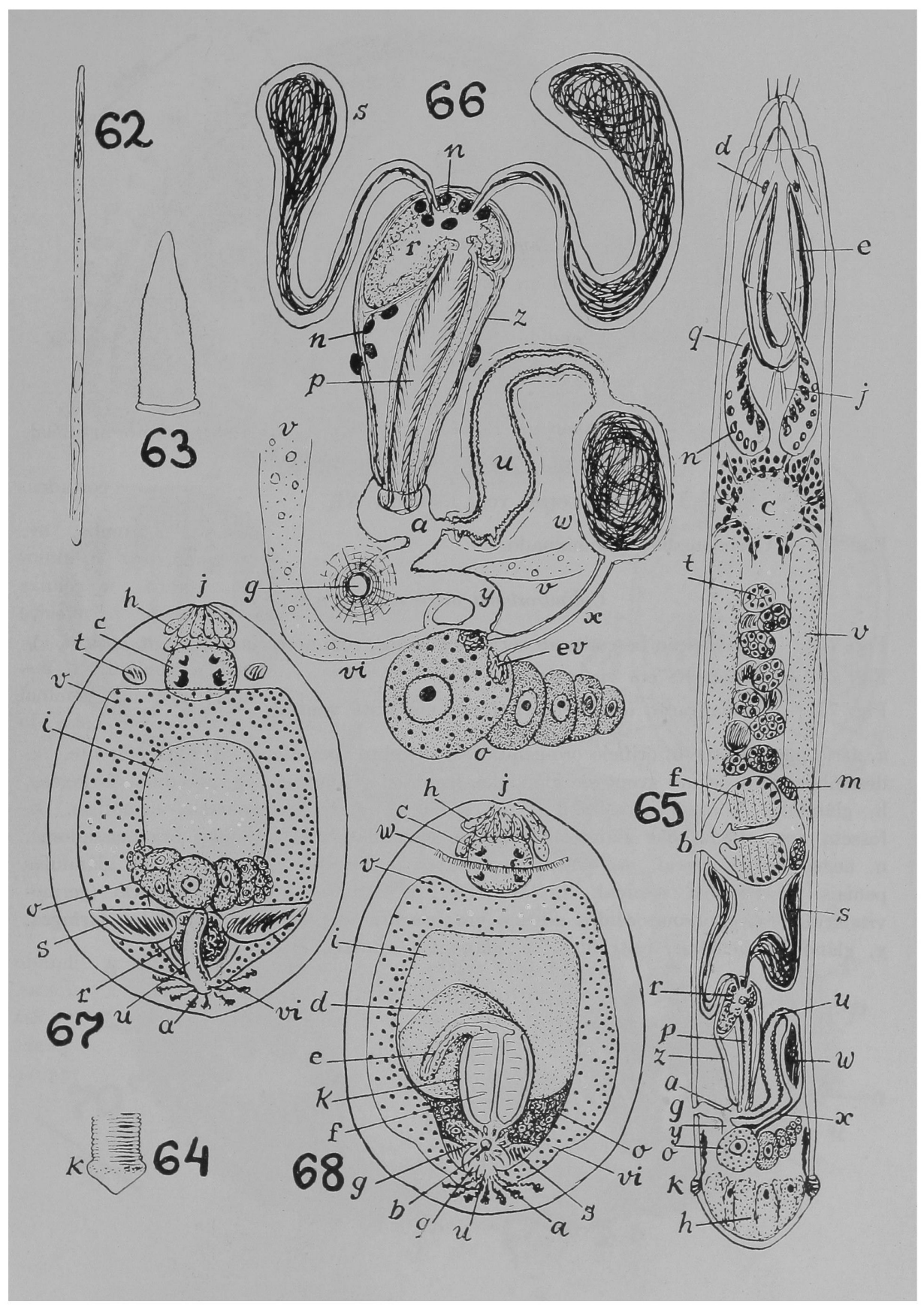




\section{ESTAMPA XII}

Rosmarium evelinæ, g. n., sp. n.

(Também Estampa XI, Figs. 67-68)

Letras veja Estampa XI

Fig. 69 - Corte mediano, combinado.

Cylindrostoma netsicum, sp. n.

Fig. 70 - Organização baseada em cortes medianos, com acréscimo de sagitais ( $t, d, s)$.

Fig. 71 - Topografia em vista dorsal.

Fig. 72 - Configuração dos germovitelários em vista ventral.

a, átrio masculino. b, orifício oro-genital. c, cérebro com olhos. d, duto eferente. e, desembocadura de um grupo de glândulas frontais. f, faringe. g, glândulas faríngeas. h, glândulas frontais (cefálicas). i, intestino. j, glândulas ventrais, cianófilas. k, fosseta dos orifícios das glândulas ventrais, cianófilas. $\mathrm{m}$, glândulas argamassadoras. $\mathrm{n}$, nervo ventro-lateral. o, ovário. $\mathrm{p}$, penis. $\mathrm{q}$, vesícula granulorum. r, glândulas peniais. $s$, vesícula seminal. $t$, testículos. $u$, ovoviteloduto. $v$, vitclário (germovitelário). w, espermatozóides alheios em procura dos ovócitos. $\mathrm{x}$, bolsa faríngea. y, glândulas ventrais, eritrófilas. z, glândulas caudais, eritrófilas. 


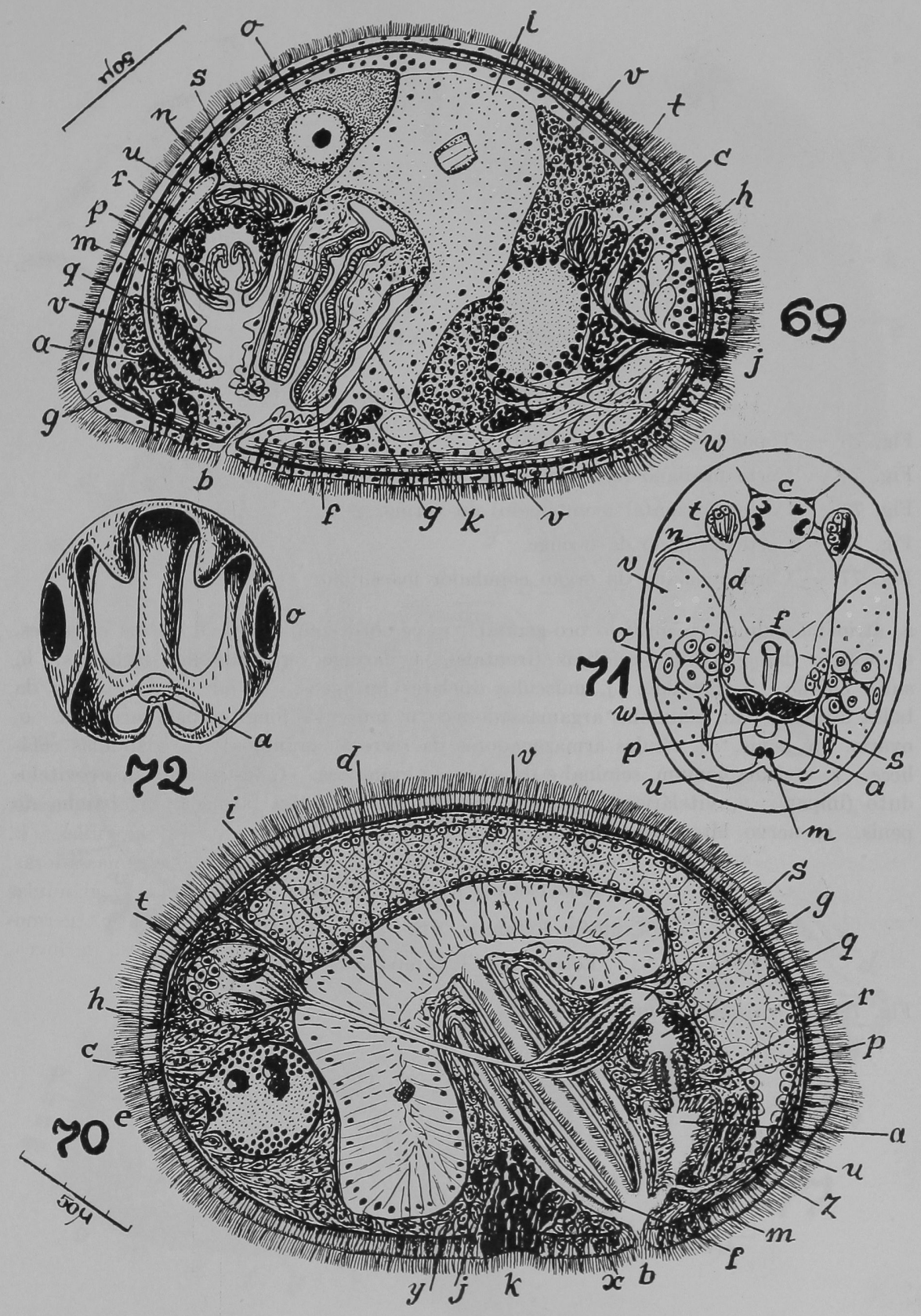


ESTAMPA XIII

Cylindrostoma ibeenum, sp. n.

Fig. 73 - Topografia em vista dorsal.

Fig. 74 - Corte mediano (combinado) do verme.

Fig. 75 - Corte horizontal (combinado) do verme.

Fig. 76 - Corte mediano da faringe.

Fig. 77 - Corte mediano do órgão copulador masculino.

a, átrio masculino. b, orifício oro-genital. c, cérebro com olhos. d, dutos eferentes. e, orifício das glândulas cefálicas (frontais). f, faringe. g, glândulas faríngeas. h, sulco ciliado. i, intestino. j, músculos anelares faríngeos. $\mathrm{k}$, núcleo do epitélio da bolsa faríngea. m, glândulas argamassadoras. n, músculos longitudinais faríngeos. o, ovário. p, penis. q, células armazenadoras da secreção granulosa. r, glândulas cefálicas. s, vesícula comum, seminal e da secreção granulosa. t, testículos. $u$, ovoviteloduto (impar). v, vitelários. $\mathrm{w}$, glândulas peniais. $\mathrm{x}$, bolsa faríngea. $\mathrm{y}$, bainha do penis. $\mathrm{z}$, nervo látero-ventral posterior.

Monoophorum tigacum, sp. $\mathrm{n}$.

(Também Estampa XIV, Figs. 79-82)

Letras veja Estampa XIV

Fig. 78 - Organização em vista dorsal. 


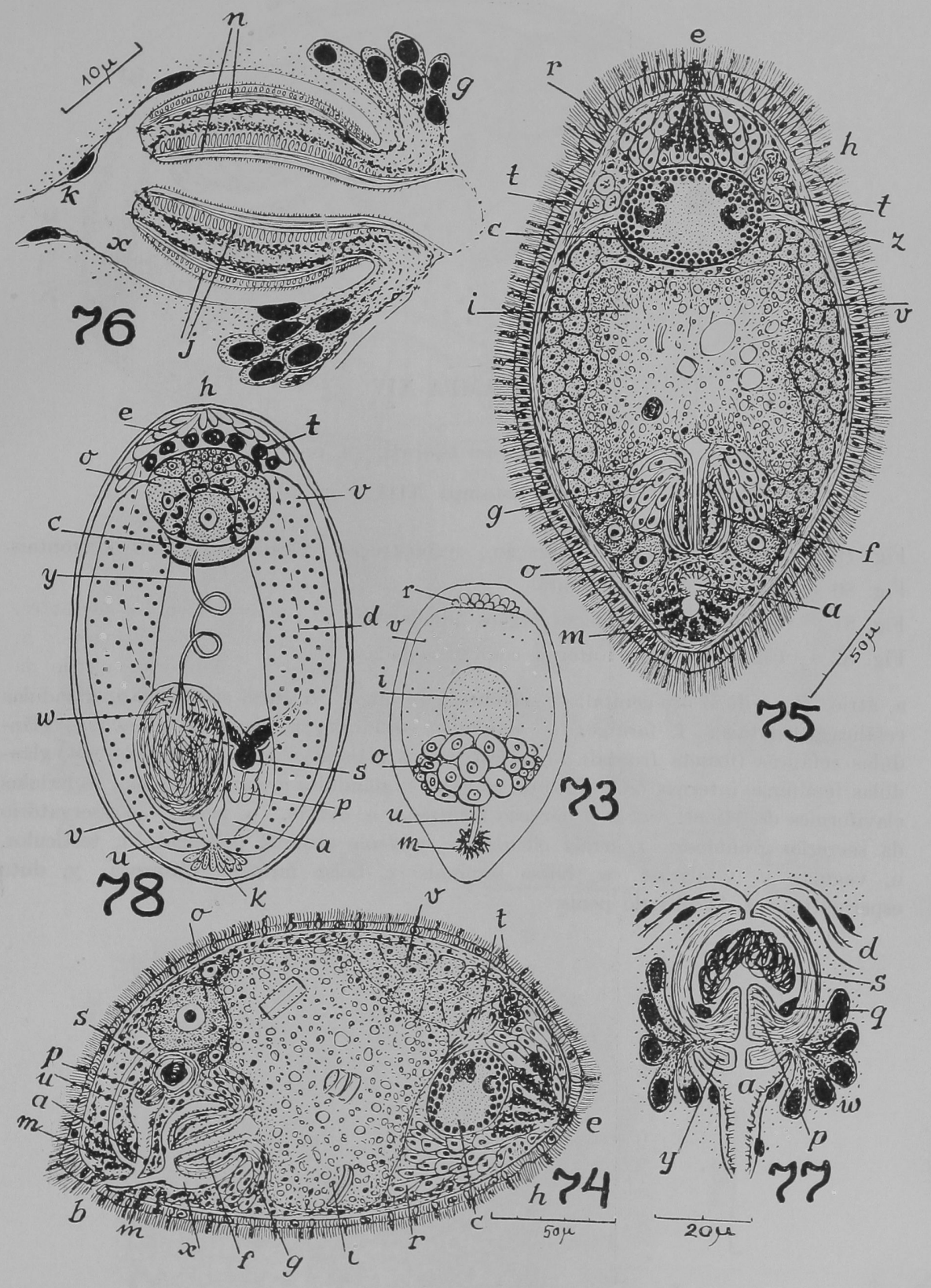


ESTAMPA XIV

Monoophorum tigacum, sp. $\mathrm{n}$.

(Também Estampa XIII, Fig. 78)

Fig. 79 - Vista lateral da organização ; reconstrução baseada em cortes horizontais. Fig. 80 - Faringe, corte horizontal.

Fig. 81 - Corte do átrio com os órgãos adjacentes.

Fig. 82 - Corte da região anterior com as gônadas.

a, átrio. b, orifício oro-genital. c, cérebro com olhos. d, duto eferente. e, glândulas cefálicas (frontais). f, faringe. g, glândulas cutâneas. h, desembocadura das glândulas cefálicas (fosseta frontal). i, intestino. j, glândulas da fenda ciliada. $\mathrm{k}$, glândulas femininas internas (glândulas da casca). l, glândulas argamassadoras. m, células claviformes de Minot. $\mathrm{n}$, anel nervoso faríngeo. o, ovário. $\mathrm{p}$, penis. $\mathrm{q}$, reservatório da secreção granulosa. $r$, fenda ciliada. $\mathrm{s}$, vesícula seminal principal. $\mathrm{t}$, testículos. $\mathrm{u}$, vagina. $\mathrm{v}$, vitelários. $\mathrm{w}$, bursa seminal. $\mathrm{x}$, bolsa faríngea (externa). $\mathrm{y}$, duto espermático. $\mathrm{z}$, bainha do penis. 

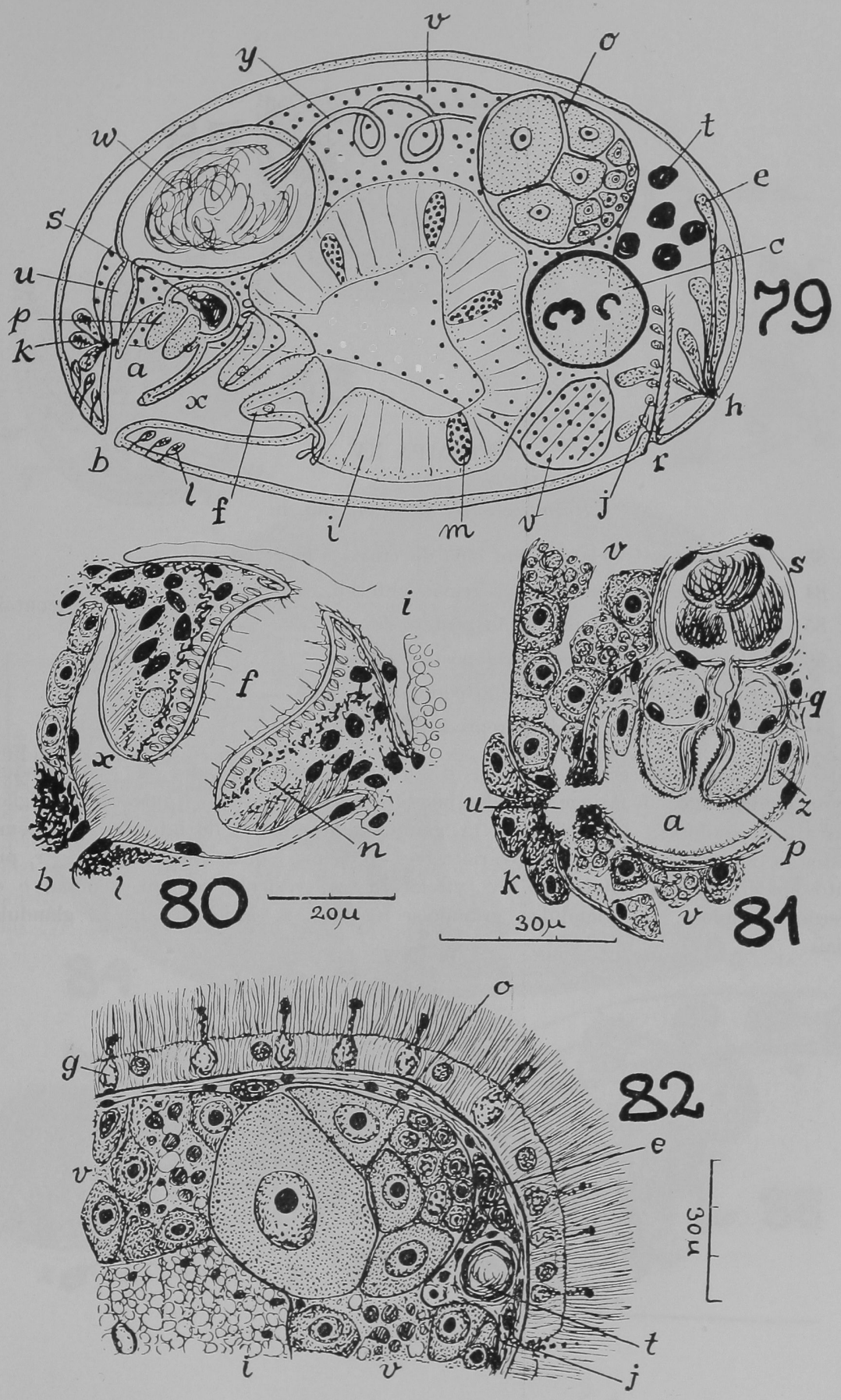


\section{ISTAMPA XV}

Puzostona cvelinx, g. n., sp. n.

Fig. 83 - Verme total, aclarado em óleo de cravo ; vista lateral.

Fig. 84 - Corte sagital, mediano na região anterior.

Fig. 85 - Corte horizontal da região póstero-dorsal.

Fig. 86 - Corte horizontal da região póstero-ventral.

Fig. 87 - Corte mediano do aparêlho copulador.

Fig. 88 - Organização dos órgãos reprodutivos.

a, átrio. b, bôca. c, cérebro com dois dos três olhos de um lado. d, ovoviteloduto comum. e, esôfago. f, faringe. g, glândulas frontais (cefálicas). i, intestino. j, glândulas argamassadoras. $\mathrm{k}$, gonóporo. $\mathrm{m}$, glândulas na entrada do intestino. $\mathrm{n}$, nematocistos no epitélio intestinal. o, ovariotestes. p, penis. $q$, bainha do penis. $r$, pigmento epidérmico. $\mathrm{u}$, viteloduto. $\mathrm{v}$, vitelários. $\mathrm{w}$, vesícula comum, seminal e da secreção granulosa. $\mathrm{x}$, glândulas grânulo-secretoras. $\mathrm{y}$, saco distal. $\mathrm{z}$, glândulas peniais. 


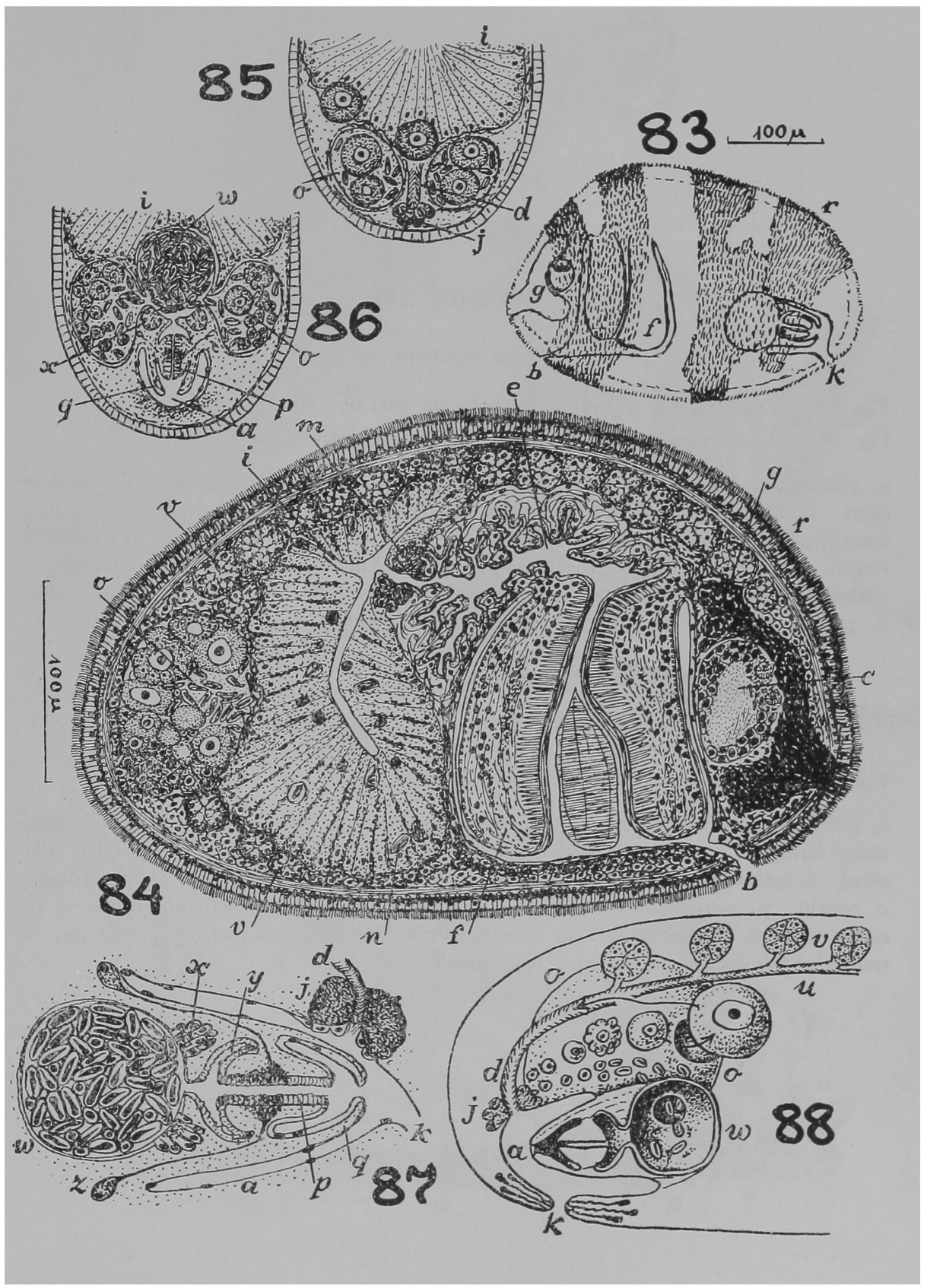




\section{ESTAMPA XVI}

Promonotus erinaceus, sp. n.

Fig. 89 - Organização do verme aclarado em óleo de cravo.

Fig. 90 - Corte mediano da região dos órgãos copulatórios.

a, glândulas argamassadoras. b, bôca. c, cérebro. d, duto ejaculatório. e, estatocisto. f, faringe. g, glândulas cefálicas. h, papilas adesivas. i, intestino. j, ligamento que suspende a vesícula seminal. $\mathrm{m}$, célula claviforme de Minot. $\mathrm{n}$, nervo faríngeo. o, ovário. p, poro masculino. q, poro feminino. $\mathrm{r}$, vesícula granulorum. $\mathrm{s}$, vesícula seminal. $\mathrm{t}$, testículos. $\mathrm{u}$, ovoviteloduto. $\mathrm{v}$, vitelário. $\mathrm{w}$, átrio masculino. $\mathrm{x}$, penis. $\mathrm{z}$, septo na raiz da faringe.

\section{Monocelis tabira, sp. $\mathrm{n}$.}

(Também Estampa XVII, Figs. 82-95)

Fig. 91 - Corte mediano da região posterior.

a, glândulas argamassadoras. b, bôca. c, cérebro com estatocisto e olhos. d, glândulas faríngeas. e, poro vaginal. f, faringe. g, glândulas cefálicas. h, papilas adesivas. i, intestino. $\mathrm{k}$, esôfago. $\mathrm{m}$, células claviformes de Minot. $\mathrm{n}$, nervo faríngeo. $\mathrm{o}$, ovário. $\mathrm{p}$, poro masculino. $\mathrm{q}$, poro feminino. $\mathrm{r}$, bursa seminal (anterior). $\mathrm{s}$, vesícula seminal. $\mathrm{t}$, testículos. $\mathrm{u}$, ovoviteloduto comum, pré-bursal. $\mathrm{v}$, vitelários. $\mathrm{z}$, trecho pré-esofágico da faringe, não ciliado. 


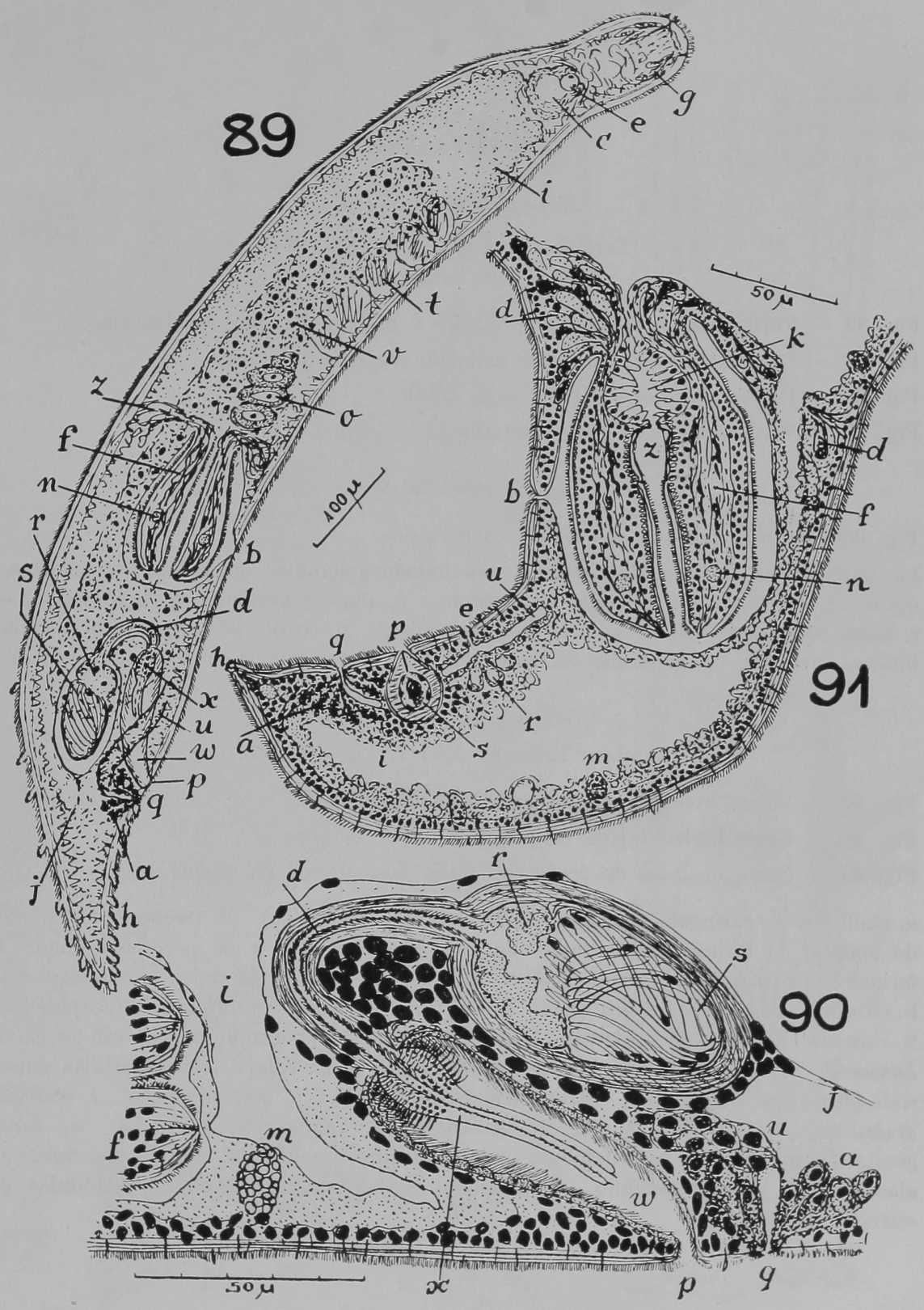




\section{ESTAMPA XVII}

Monocelis tabira, sp. n.

(Também Estampa XVI, Fig. 91)

Letras veja Estampa XVI

Fig. 92 - Verme com a faringe (f) protraida; preparação total em bálsamo.

Fig. 93 - Organização de um verme aclarado em óleo de cravo.

Fig. 94 - Região anterior em preparação total.

Fig. 95 - Vista ventral da parte posterior.

\section{Mesoda gabriellæ Marc.}

Fig. 96 - Corte mediano dos órgãos copulatórios.

bu, parênquima da bolsa do cirro. d, ovoviteloduto comum. g, glândulas argamassadoras. $\mathrm{i}$, intestino. $\mathrm{n}$, vesícula granulorum. $\mathrm{p}$, poro masculino. $\mathrm{q}$, poro feminino. $\mathrm{r}$, bursa ressorvente (posterior). s, vesícula seminal. $\mathrm{u}$, cirro. w, bursa seminal (copulatória, anterior). $\mathrm{x}$, glândulas da bursa seminal. y, vagina. z, canal genital feminino.

Necia sopha, g. n., sp. n.

(Também Estampa XVIII, Figs. 100-102)

Fig. 97 - Verme vivente, imaturo, em vista dorsal.

Fig. 98 - Corte horizontal da região posterior do corpo.

Fig. 99 - Corte mediano do órgão copulador masculino e da vagina.

a, anel nervoso faríngeo. b, bôca. c, cérebro com estatocisto. d, trecho ectal, ciliado, do epitélio da faringe. e, esôfago. es, esfincteres da bôca e do poro masculino. f, faringe ; foi marcado o trecho não ciliado do epitélio. g, glândulas argamassadoras. h, citosomas das glândulas faríngeas. i, intestino. j, núcleos aprofundados da epiderme. k, camada cobertora da epiderme. l, músculos cutâneos longitudinais. m, células claviformes de Minot. n, nervos látero-ventrais, reunidos na cauda, com as células sensoriais piriformes, pálidas. o, ovário. p, poro masculino. q, poro feminino. $\mathrm{l}$, secreção granulosa. s, vesícula comum. $\mathrm{t}$, testículos. $\mathrm{u}$, vagina. $\mathrm{v}$, vitelários. $\mathrm{w}$, canal genital feminino. wi, ovoviteloduto; foi marcado o ponto da reunião dos dois. $\mathrm{x}$, glândulas no poro masculino. y, glândulas apinceladas, adesivas. z, glândulas de secreção baciliforme. 
E. MARCUS - TURBELLARIA BRASILEIROS (8) ESTAMPA XVII

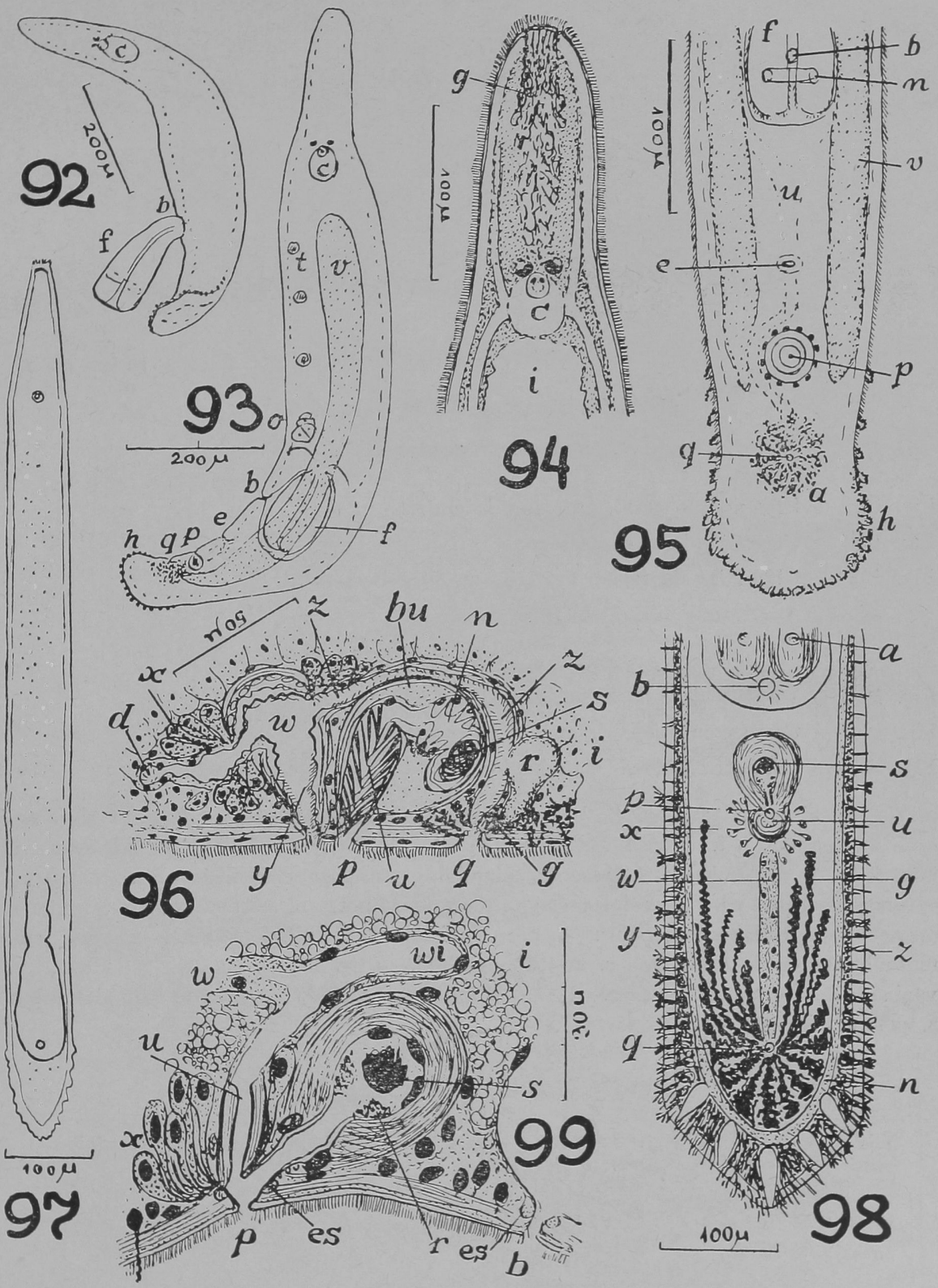




\section{ESTAMPA XVIII}

Necia sopha, g. n., sp. n.

(Também Estampa XVII, Figs. 97-99)

Letras veja Estampa XVII

Fig. 100 - Organização geral, em vista lateral.

Fig. 101 - Corte mediano da faringe.

Fig. 102 - Glândulas da região caudal, em corte horizontal.

Peraclistus itaipus, sp. n.

Fig. 103 - Vista ventral da organização.

Fig. 104 - Corte combinado da região posterior.

Fig. 105 - Corte transversal, combinado de três cortes successivos.

a, órgão músculo-glandular. b, bôca. c, cérebro com estatocisto. d, duto eferente. e, bolsa faríngea. f, faringe. g, glândulas argamassadoras. h, papilas adesivas. i, intestino. j, glândulas faríngeas. k, glândulas cutâneas cianófilas. l, musculatura cutânea longitudinal. m, células claviformes de Minot. n, nervos (ventro-laterais e faríngeo). o, ovários. $p$, penis. $q$, poro masculino. $r$, orifício vaginal externo. rm, musculatura cutânea anelar. $\mathrm{s}$, vesícula seminal. $\mathrm{t}$, testículos. $\mathrm{u}$, ovoviteloduto. $\mathrm{v}$, vagina. $\mathrm{w}$, bursa ressorvente. $\mathrm{x}$, vitelários. $\mathrm{y}$, poro do órgão músculo-glandular. $\mathrm{z}$, poro feminino. 
E. IAPCUS - TURBELLARIA BRASILEIROS (8) ESTAMPA XVIII

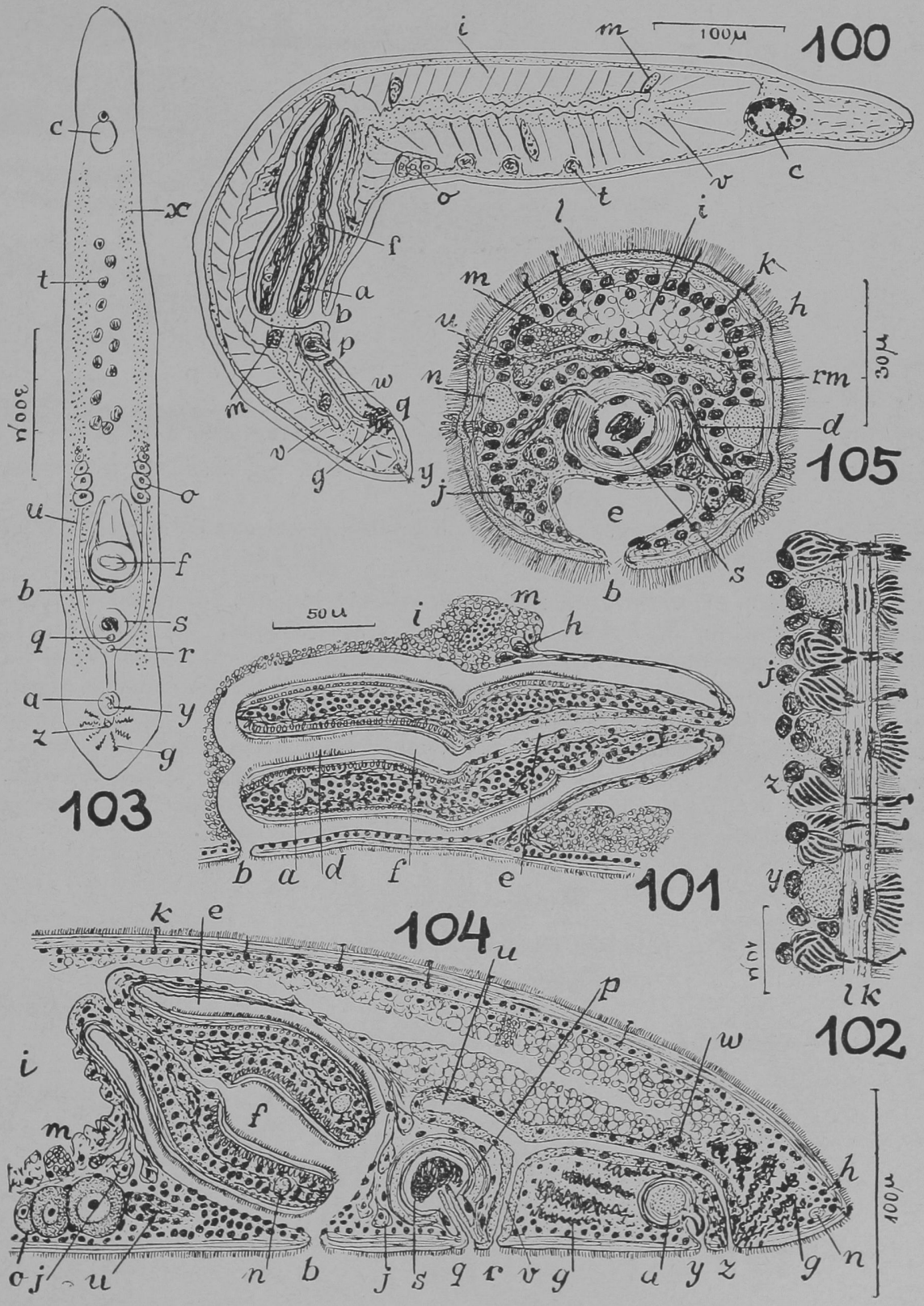




\section{ESTAMPA XIX}

\section{Philosyrtis eumeca, sp. n.}

Fig. 106 - Organização do verme adulto ; vista ventral.

Fig. 107 - Verme jovem, vivente, visto do lado ventral.

Fig. 108 - Corte transversal, ao nível do estatocisto.

Fig. 109 - Corte horizontal, da região média para trás, combinado de três cortes successivos.

Fig. 110 - Cerdas do aparêlho copulatório masculino, desenhadas do animal vivente, comprimido.

a, átrio. b, bôca. c, cérebro. ci, glândula de secreção pegajosa. d, divertículo intestinal. e, estatocisto. f, faringe. g, glândulas argamassadoras. go, gonóporo. $\mathrm{h}$, diafragma faríngeo-intestinal. $\mathrm{i}$, intestino. $\mathrm{j}$, bolsa faríngea. $\mathrm{k}$, papilas adesivas. l, lóbulos anteriores do cérebro (gânglios pré-cerebrais). $\mathrm{m}$, células claviformes de Minot. $\mathrm{n}$, anel nervoso da faringe. o, ovócitos, em parte, já inseminados. p, aparêlho copulatório masculino. $\mathrm{q}$, células rabditógenas. $\mathrm{r}$, rabditos. $\mathrm{s}$, vesícula seminal principal. sc, estereocílios. sg, células grânulo-armazenadoras. t, testículos. u, ovoviteloduto. $\mathrm{v}$, vitelários. $\mathrm{w}$, campos ciliados. $\mathrm{x}$, sola rasteira ciliada. $\mathrm{y}$, vesículas seminais accessórias. z, desembocadura dos ovovitelodutos reunidos no átrio.

Kata leroda, sp. n.

(Também Estampa XX, Figs. 112-115)

Letras veja Estampa XX

Fig. 111 - Corte transversal da região da bursa (w); desenho topográfico. 


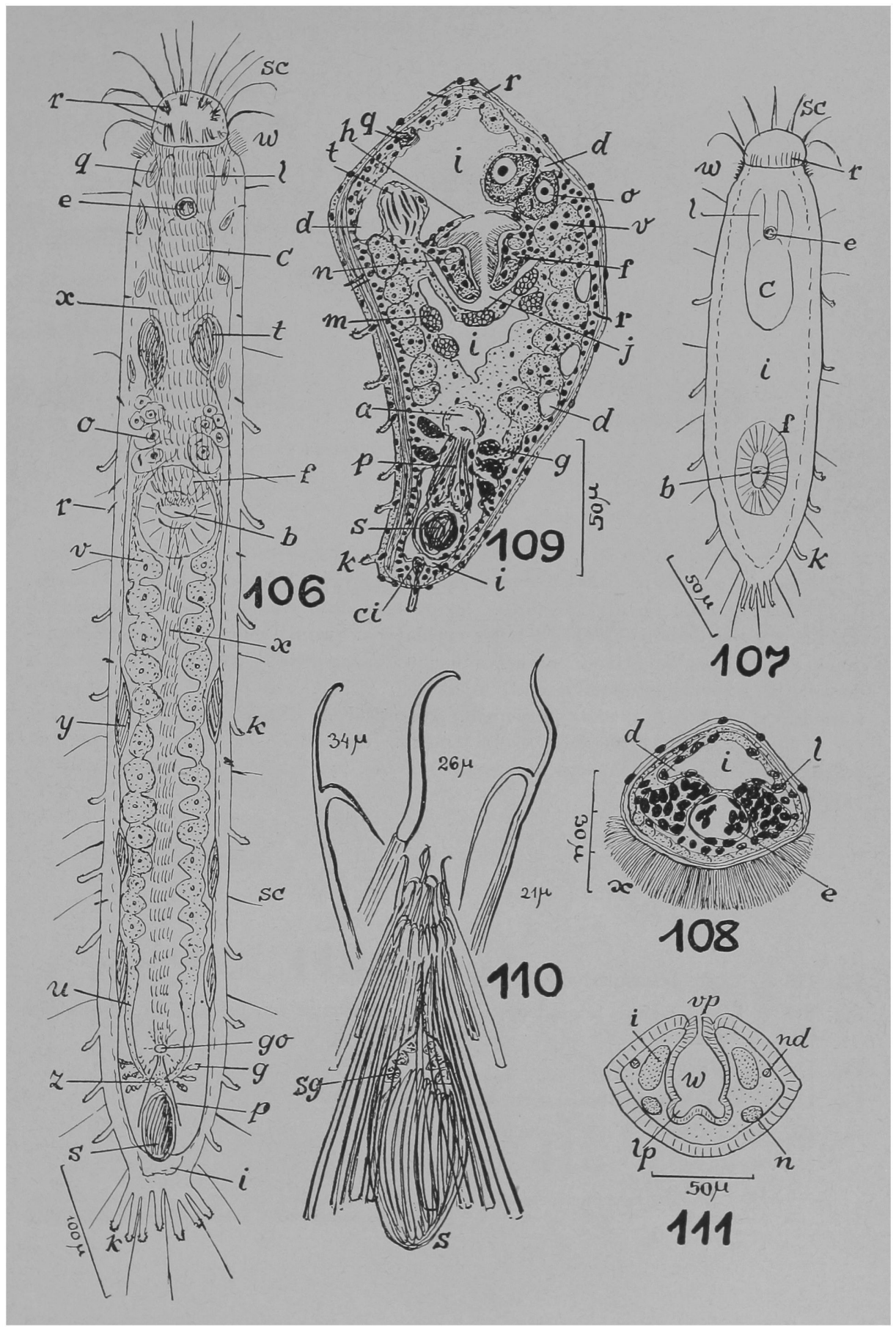




\section{ESTAMPA XX}

Kata leroda, sp. n.

(Também Estampa XIX, Fig. 111)

Fig. 112 - Verme total, montado em bálsamo; vista ventral.

Fig. 113 - Corte horizontal da região anterior.

Fig. 114 - Corte transversal da região pré-faríngea.

Fig. 115A - Corte mediano (combinado) da região posterior.

Fig. 115B - Aparêlho cuticular masculino.

Fig. 115C - Um acúleo do mesmo.

a, átrio. b, bôca. c, cérebro com os dois olhos. d, duto ejaculatório. e, estatocisto. f, faringe. g, gonóporo. h, glândulas argamassadoras. i, intestino. j, bolsa faríngea. $\mathrm{k}$, células adesivas. l, ovoviteloduto. lc, ovoviteloduto comum. lp, canais ventrocaudais entre os ovovitelodutos e a bursa copulatória. m, musculatura cutânea longitudinal. mi, clavas de Minot. $\mathrm{n}$, nervo longitudinal ventral. nd, nervo longitudinal dorsal. nl, nervo longitudinal lateral. o, ovário. p, bainha do penis. q, células rabditógenas. r, rabditos. $\mathrm{s}$, vesícula seminal. $\mathrm{t}$, testículos. $\mathrm{u}$, sola ciliada. $\mathrm{v}$, vitelários. va, vagina. vg, glândulas da vesícula seminal. vp, orifício externo da vagina. w, bursa copulatória. $\mathrm{x}$, intestino pré-cerebral sólido. $\mathrm{y}$; papila sensorial anterior. $\mathrm{z}$, papila sensorial posterior.

Nematoplana asita, sp. n.

(Também Estampa XXI, Figs. 121-127)

Letras veja Estampa XXI

Fig. 116 - Corte horizontal do cérebro com os olhos.

Fig. 117 - Corte sagital, lateral, da região dos ovários de um verme do início da fase feminina.

Fig. 118 - Estilete.

Fig. 119 - Gônadas maduras, corte sagital.

Fig. 120 - Esquema de um corte transversal da região dos ovários. 

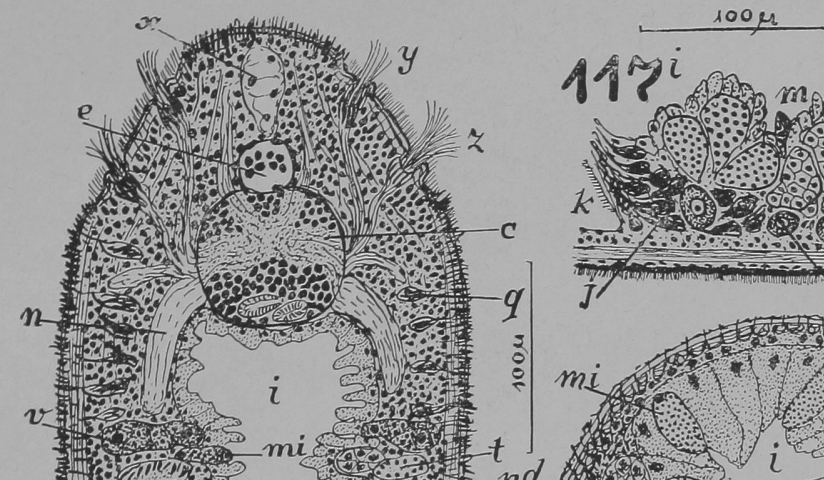

t.

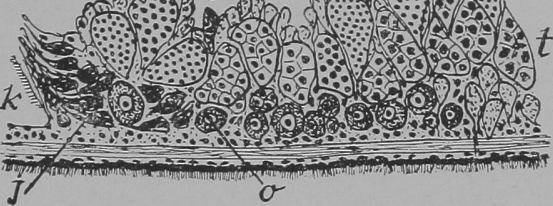

m

113

$9+$

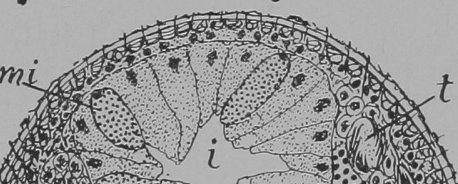

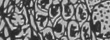

(3)

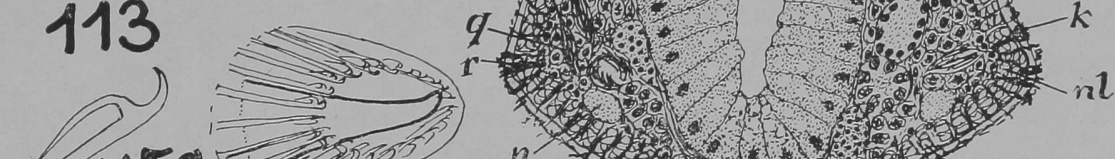

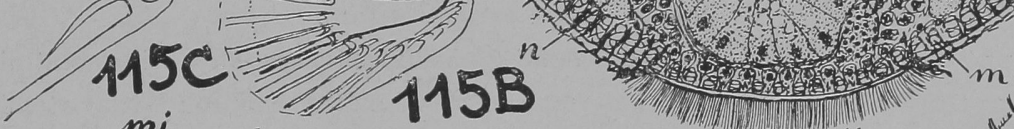

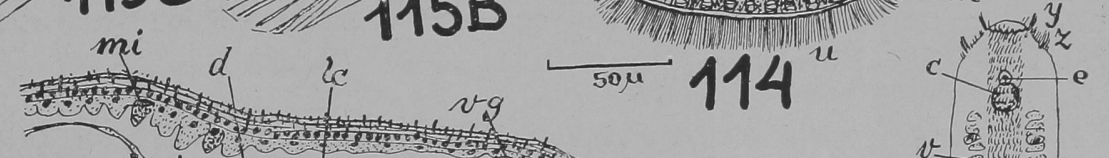
1.

o j a

$p$

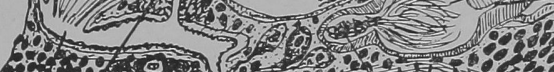

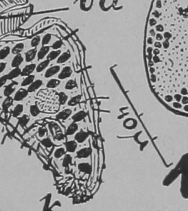

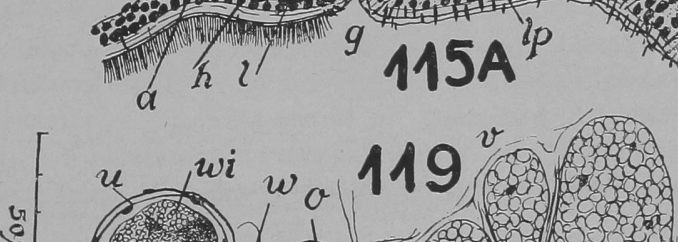

\&

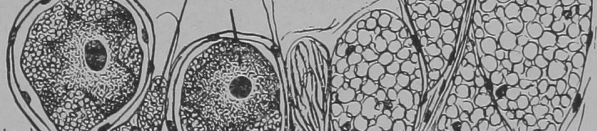

(18) W W

1.9.)

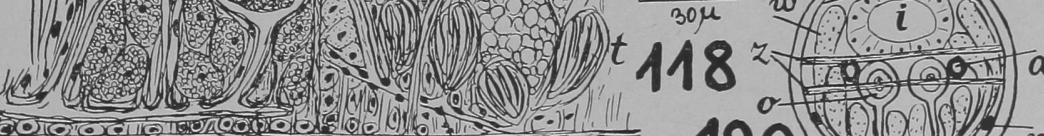

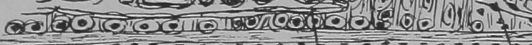

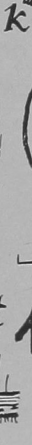

e

d 120 e. 


\section{ESTAMPA XXI}

Nematoplana asita, sp, $\mathrm{n}$.

(Também Estampa XX, Fig. 116-120)

Fig. 121 - Verme vivente.

Fig. 122 - Corte mediano da região anterior.

Fig. 123 - Corte mediano da faringe de um verme imaturo.

Fig. 124 - Ôrgãos reprodutivos de um verme completamente maduro; vista ventral.

Fig. 125 - Ôrgãos reprodutivos de um verme completamente maduro; vista lateral.

Fig. 126 - Vista lateral da região posterior de um verme crescido, imaturo, na mesma escala como a Fig. 125.

Fig. 127 - Corte combinado dos órgãos copulatórios de um verme maduro com faringe involuída.

a, glândulas argamassadoras. b, bôca. c, cérebro com olhos. ci, cílios cefálicos maiores. d, duto eferente. di, diafragma faríngeo-intestinal. e, ovovitelodutos. f, faringe. g, glândulas cutâneas. gc, glândulas cefálicas. h, glândulas caudais, adesivas. i, intestino. ic, intestino cefálico. j, glândulas faríngeas. $\mathrm{k}$, bolsa faríngea (externa). l, comunicação entre o intestino pré-faríngeo e o caudal. $\mathrm{m}$, células claviformes de Minot. $\mathrm{n}$, nervos. o, ovócitos. p, estilete penial. pa, parênquima sustentador da região cerebral. q, vesícula seminal accessória, impar. r, reservatório da secreção granulosa. $\mathrm{s}$, vesículas seminais principais, pares. $\mathrm{t}$, testículos. $\mathrm{u}$, túnica ovárica. $\mathrm{v}$, vitelários. w, células viteláricas da região dos ovários. wi, transformações no ovoplasma dos ovócitos em crescimento. $\mathrm{x}$, poro masculino. $\mathrm{y}$, poro feminino. $\mathrm{z}$, músculos tranśversais da região ovárica. 


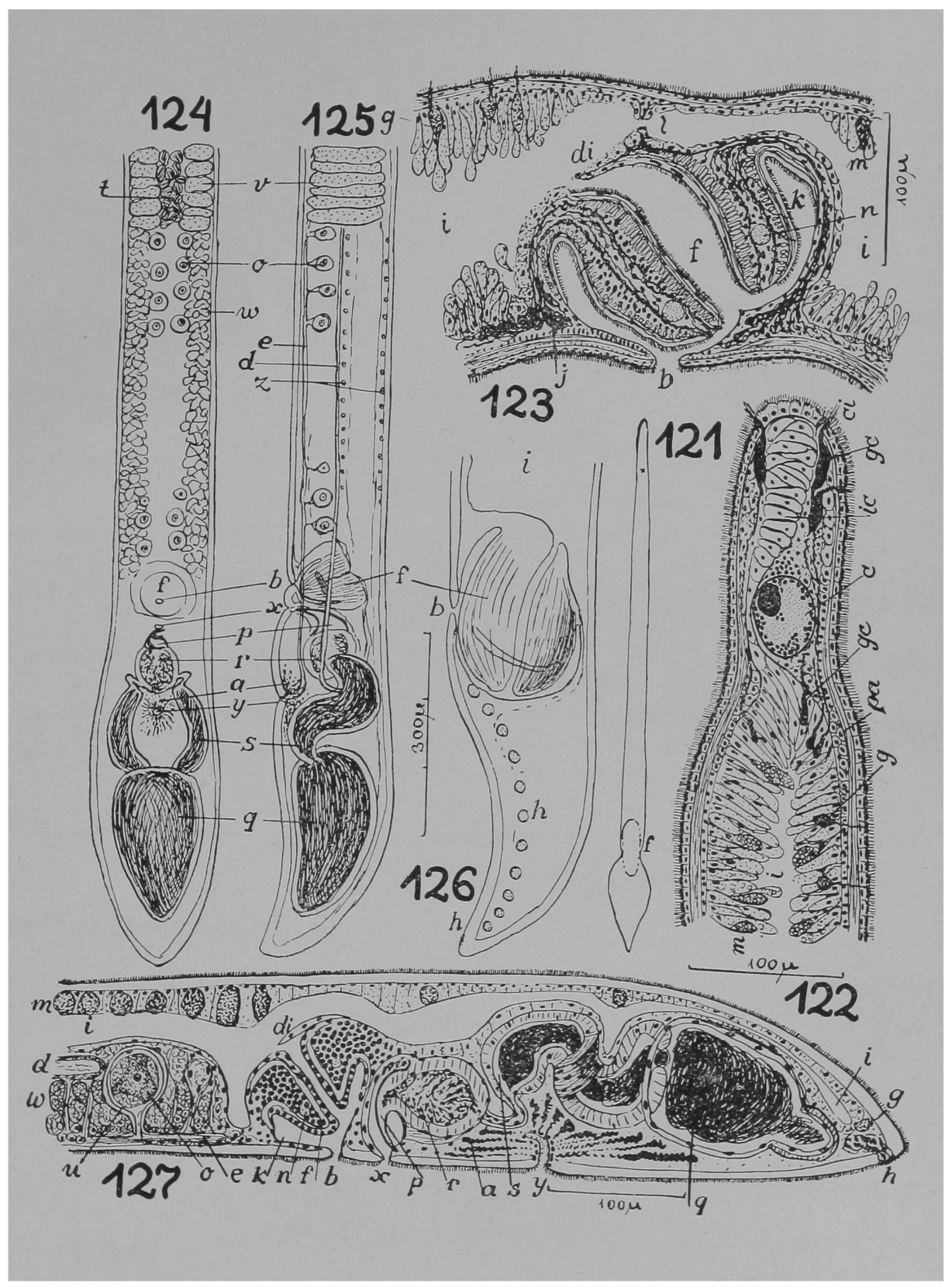




\section{ESTAMPA XXII}

Tabaota curiosa, g. n., sp. n.

Também Estampa XXIII, Figs. 136-141)

Letras veja Estampa XXIII

Fig. 128 - Cabeça do verme vivente, em vista dorsal.

Fig. 129 - Cauda do verme vivente, em vista lateral.

Fig. 130 - Cabeça do verme vivente, comprimida ; vista ventral. Ao lado, os órgãos refrativos com aumento maior que na figura principal.

Fig. 131 - Corte transversal do intestino com hemácias de peixe (pe) incorporadas pelas células intestinais.

Fig. 132 - Corte transversal da região pré-faríngea do verme maduro.

Fig. 133 - Região posterior do verme maduro ; vista ventral.

Fig. 134 - Região posterior do verme maduro; vista lateral.

Fig. 135 - Corte de um dos órgãos refrativos. 


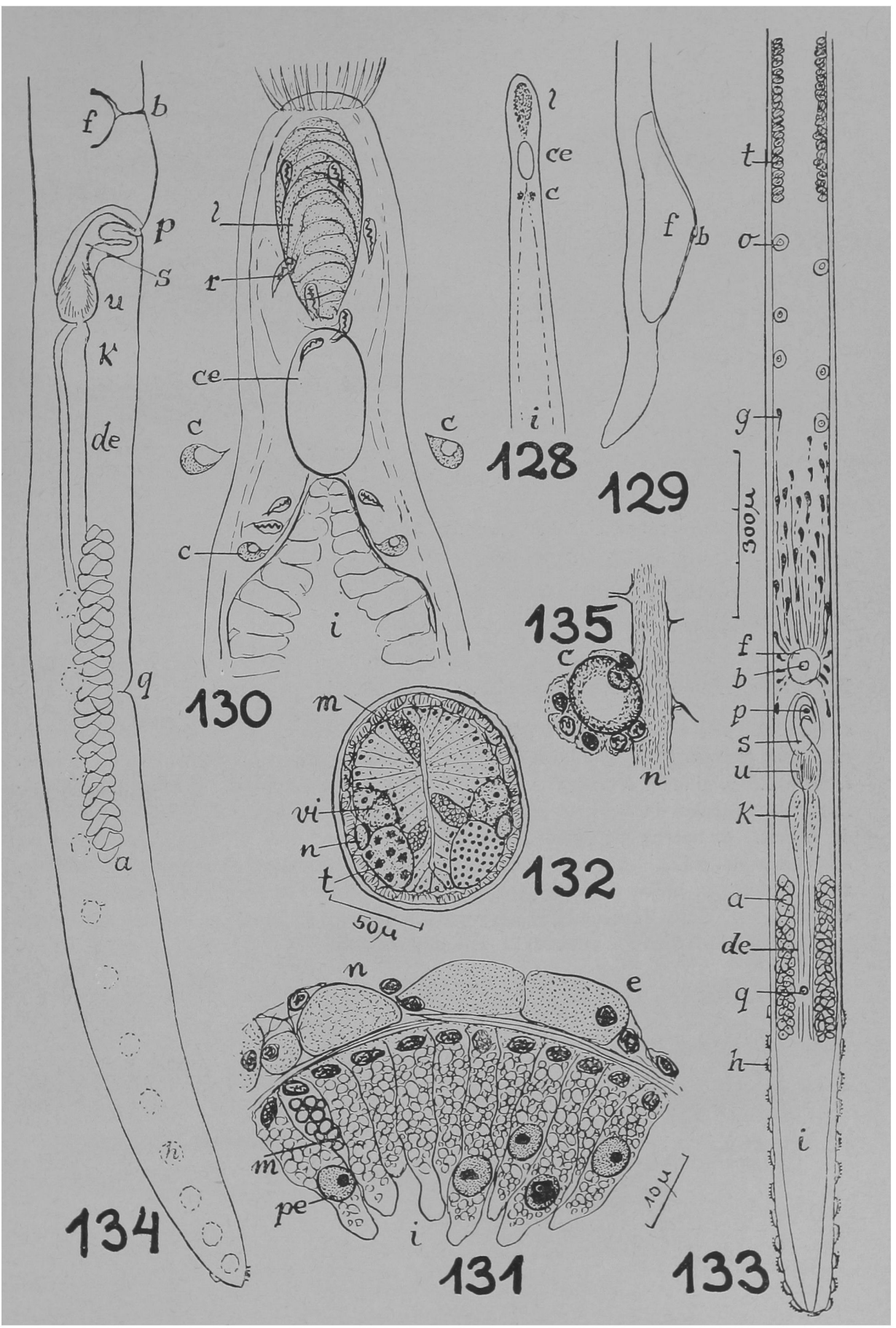




\section{ESTAMPA XXIII}

Tabaota curiosa, g. n., sp. n.

(Também Estampa XXII, Figs. 128-135)

Fig. 136 - Corte tangencial das glândulas adesivas caudais.

Fig. 137 - Corte mediano da faringe.

Fig. 138 - Corte horizontal, dorsal, da faringe com bolsa faríngea.

Fig. 139 - Extremidade caudal, corte mediano.

Fig. 140 - Extremidade caudal, corte horizontal.

Fig. 141 - Órgão copulador masculino ; vista lateral.

a, glândulas argamassadoras. b, bôca. c, órgãos refrativos. ce, cérebro. d, epiderme. de, dutos eferentes. e, glândulas cutâneas eritrófilas. eu, célula formadora do estilete. f, faringe. g, glândulas faríngeas. h, glândulas adesivas caudais. i, intestino. j, esôfago. $\mathrm{k}$, vesículas da secreção granulosa. $\mathrm{l}$, intestino cefálico. $\mathrm{m}$, células claviformes de Minot. n, nervos principais ventro-laterais. o, ovários. p, poro masculino. pe, eritrócitos de peixe. q, poro feminino. r, órgãos terminais excretórios. $s$, estilete. $\mathrm{t}$, testículos. $\mathrm{u}$, bulbo do órgão copulatório masculino. $\mathrm{v}$, poro anal transitório. vi, vitelário. $\mathrm{w}$, nervo faríngeo. $\mathrm{x}$, diafragma faríngeo. $\mathrm{y}$, canal de comunicação entre $\mathrm{o}$ intestino pré-faríngeo e o caudal. $\mathrm{z}$, bolsa faríngea. 


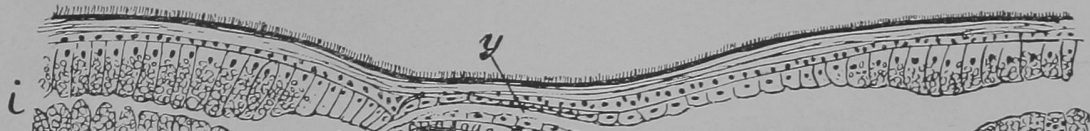

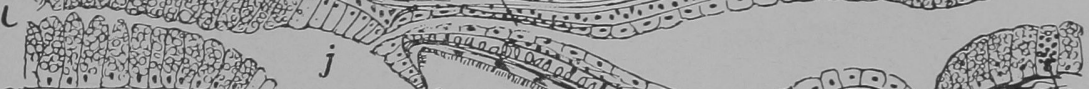

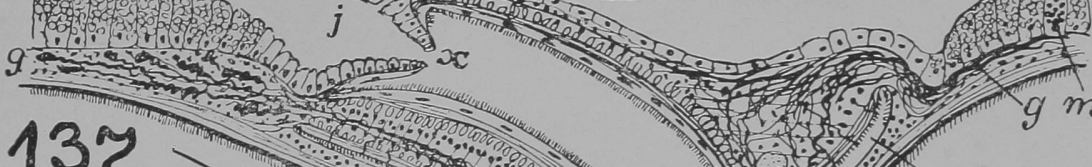
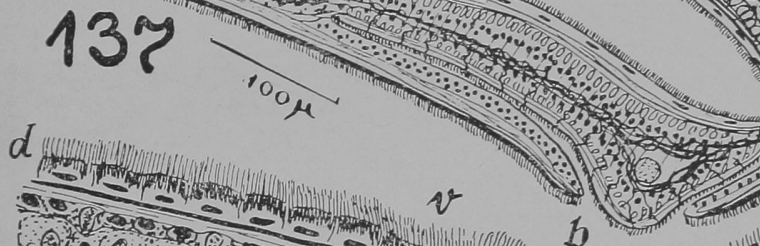

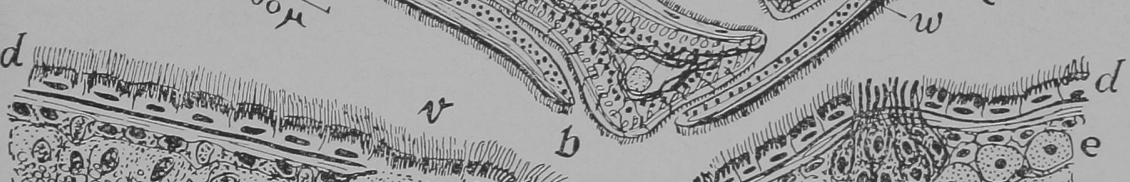

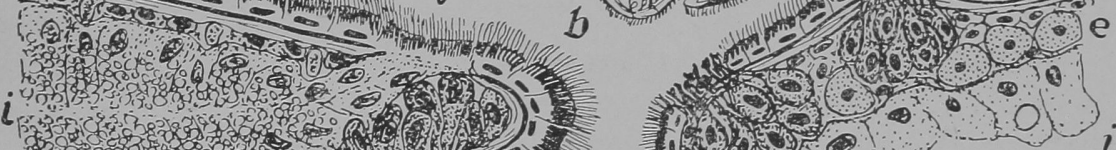

Find

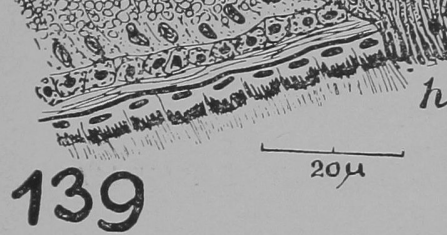

$h$

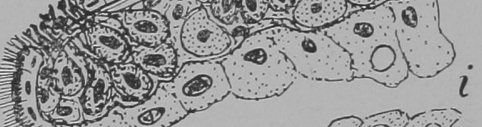

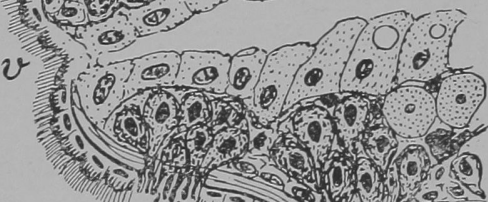

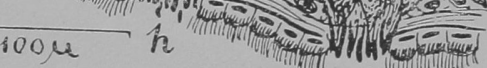
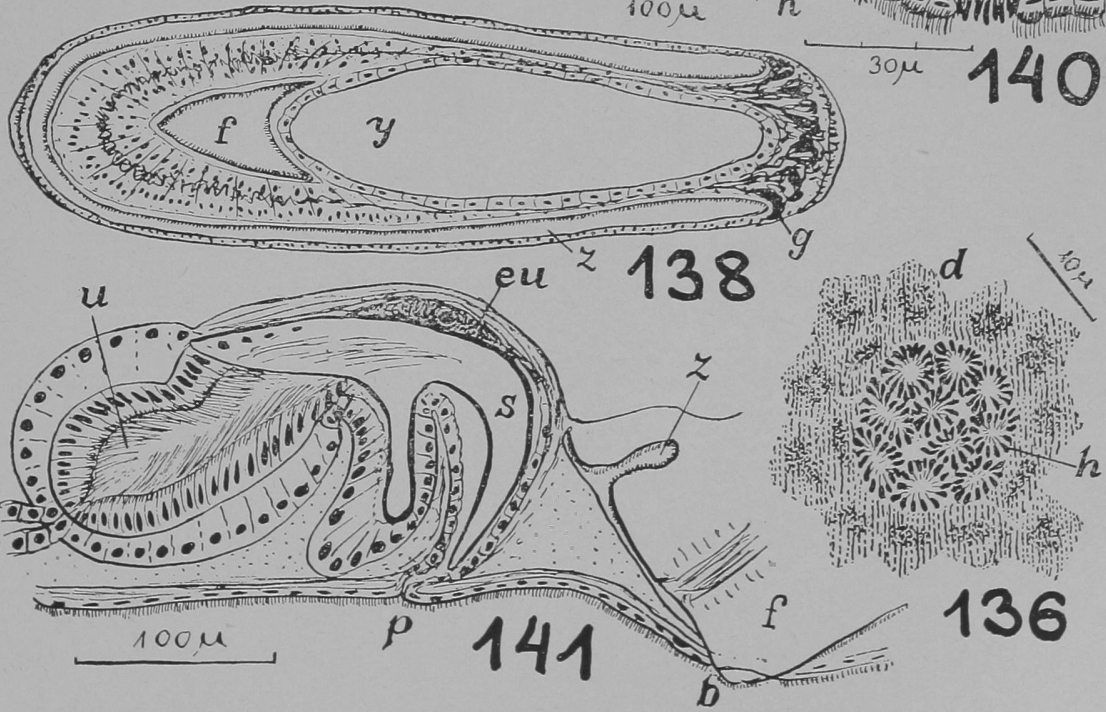

$\because=\frac{1}{2}$

- = In

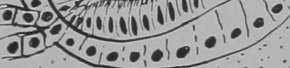

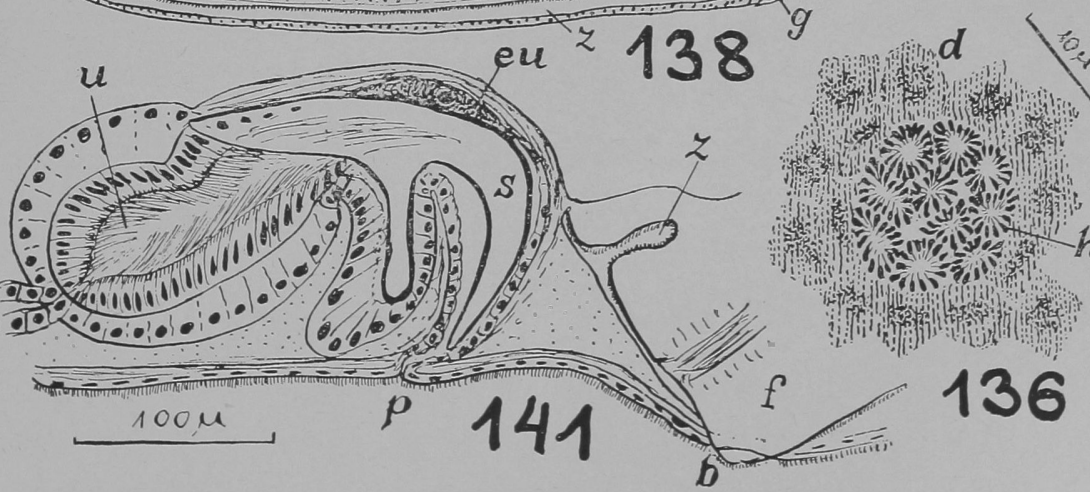




\section{ESTAMPA XXIV}

Adenoplana evelinæ, sp. n.

(Também Estampa XXV, Figs. 143-144; Estampa XXVI, Figs. 145-147)

Letras veja Estampa XXV

Fig. 142 - Vista ventral do verme. 


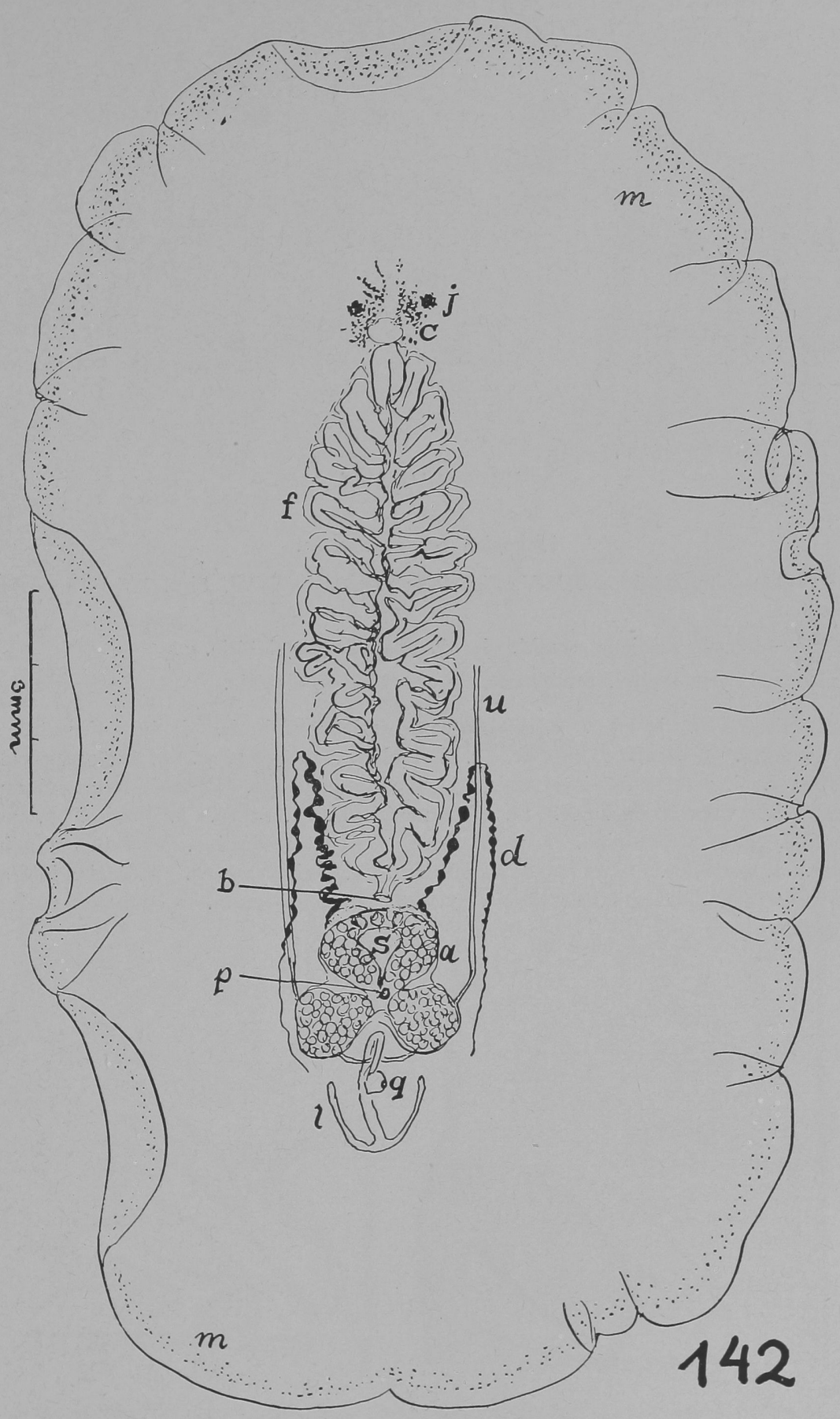




\section{ESTAMPA XXV}

Adenoplana evelinæ, sp. n.

(Também Estampa XXIV. Fig. 142 ; Estampa XXVI, Figs. 145-147)

Fig. 143 - Corte mediano, combinado, do aparêlho copulatório.

Fig. 144 - Corte sagital, combinado, do aparêlho copulatório.

a, átrio masculino. b, bôca. c, cérebro com os olhos cerebrais. d, duto eferente. e, bolsa faríngea. f, dobras da faringe. g, glândulas argamassadoras. h, órgãos músculoglandulares. i, divertículos intestinais. j, olhos tentaculares. $\mathrm{k}$, vesícula granulorum. l, ampola da vesícula de Lang. $\mathrm{m}$, olhos marginais. $\mathrm{n}$, nervo. o, ovários. $\mathrm{p}$, poro masculino. q, poro feminino. $\mathrm{r}$, poro ao lado do poro masculino. $\mathrm{s}$, duto masculino comum. $\mathrm{t}$, testículos. $\mathrm{u}$, útero e dutos uterinos. $\mathrm{v}$, vagina externa. $\mathrm{w}$, vagina interna. $\mathrm{x}$, duto das glândulas argamassadoras. $\mathrm{y}$, duto uterino comum. $\mathrm{z}$, duto da vesícula de Lang. 
E. MARCUS - TURBELLARIA BRASILEIROS (8) ESTAMPA XXV

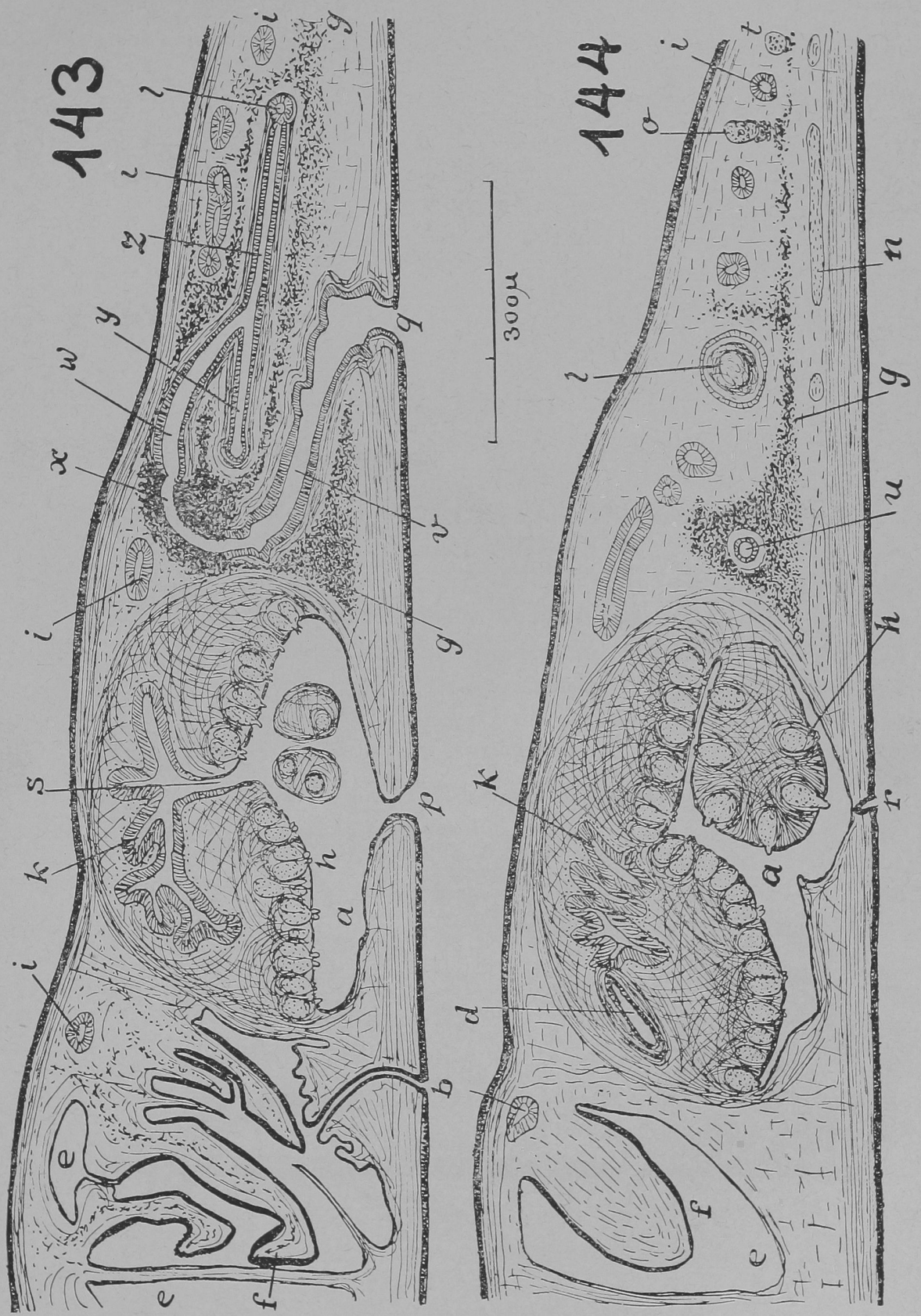


Adenoplana evelinæ, sp. $\mathrm{n}$.

(Também Estampa XXIV, Fig. 142 ; Estampa XXV, Figs. 143-144)

Letras veja Estampa XXV

Fig. 145 - Região anterior do corpo ; desenho com o prisma de projeção.

Fig. 146 - Ôrgãos músculo-glandulares do átrio.

Fig. 147 - Reentrância da epiderme, ao lado do poro masculino.

Hoploplana divæ, sp. n.

(Também Estampa XXVII, Figs. 149-151)

Letras veja Estampa XXVII

Fig. 148 - Organização do aparêlho copulador. 
E. MARCUS - TURBELLARIA BRASILEIROS (8) ESTAMPA XXVI

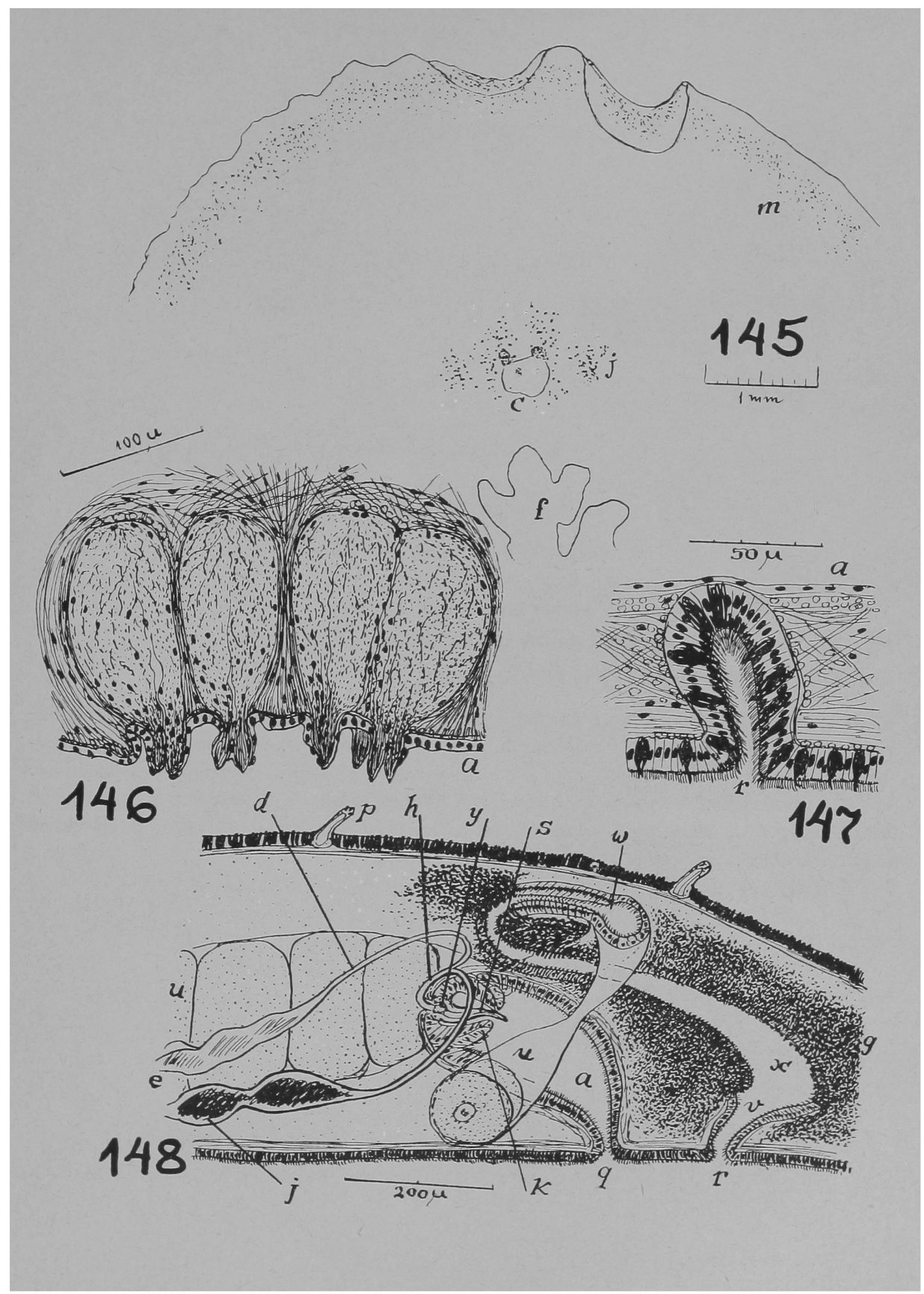




\section{ESTAMPA XXVII}

Hoploplana divæ, sp. n.

(Também Estampa XXVI, Fig. 148)

Fig. 149 - Vista ventral do verme em óleo de cravo.

Fig. 150 - Olhos desenhados com o prisma de projeção.

Fig. 151 - Corte da epiderme dorsal com papila.

a, átrio masculino. b, bôca. c, cérebro. d, canal seminal. e, duto eferente. f, faringe. g, glândulas argamassadoras. h, duto ejaculatório. j, vesículas seminais accessórias. $\mathrm{k}$, bainha do penis. $\mathrm{n}$, olhos cerebrais. o, ovários. $\mathrm{p}$, papilas epidérmicas. $q$, poro masculino. $r$, poro feminino. $s$, estilete penial. $t$, tentáculos com os olhos tentaculares. $\mathrm{u}$, útero. $\mathrm{v}$, vagina externa. $\mathrm{w}$, vagina interna. $\mathrm{x}$, duto das glândulas argamassadoras. $\mathrm{y}$, vesícula granulorum. $\mathrm{z}$, rabditos. 


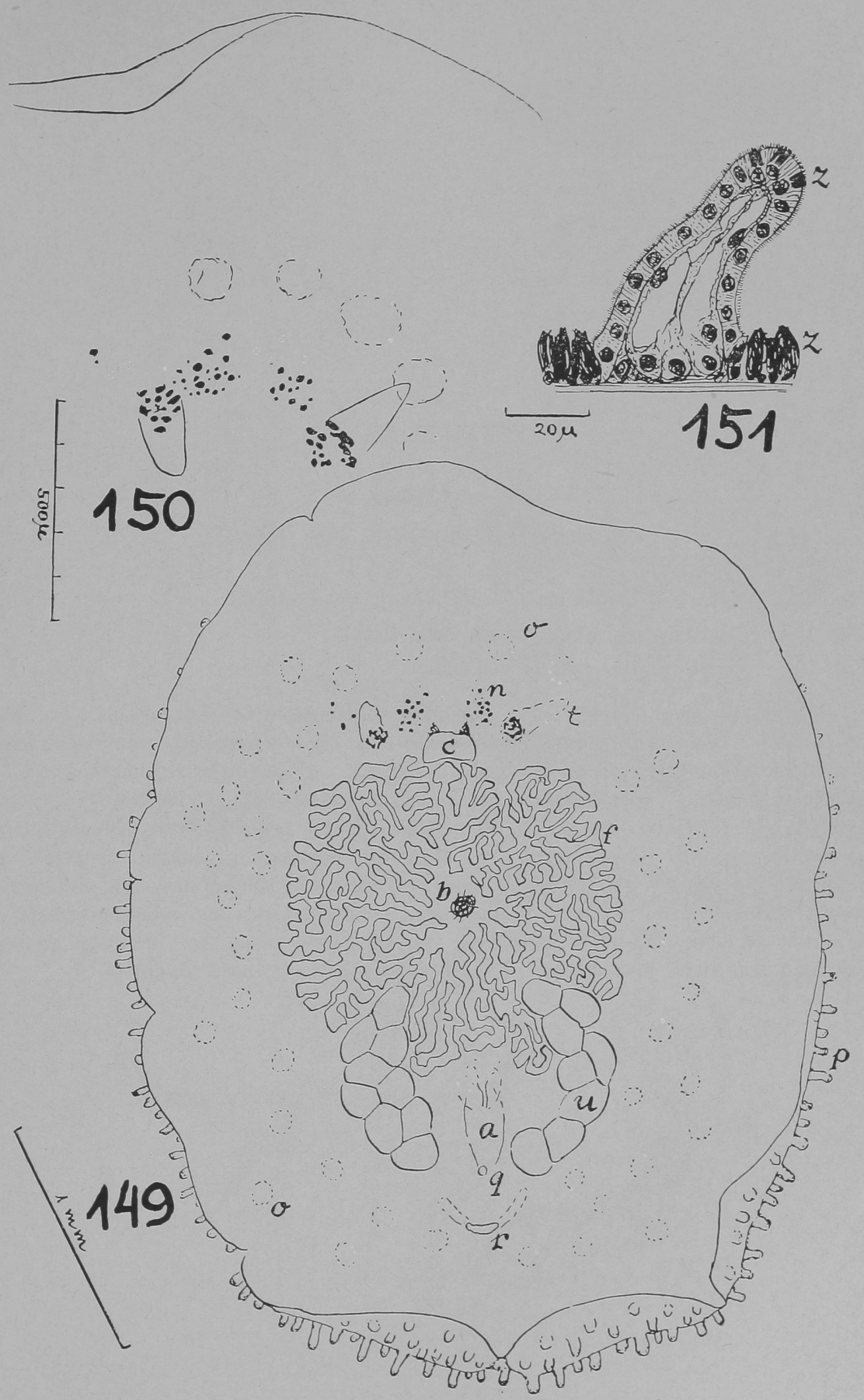




\section{ESTAMPA XXVIII}

Pseudoceros evelinæ, sp. n.

(Também Estampa XXIX, Figs. 155-157)

Fig. 152 - Verme aclarado em óleo de cravo; vista ventral.

Fig. 153 - Extremidade anterior, em vista dorsal.

Fig. 154 - Corte sagital com as gônadas.

a, olhos tentaculares dorso-distais. b, olhos tentaculares dorso-proximais. bo, bolsa do penis. c, olhos tentaculares ventro-distais. d, olhos tentaculares ventro-proximais. de, dútulo eferente. e, área cerebral. f, faringe. g, glândulas argamassadoras. gl, glândulas cutâneas aprofundadas. h, bolsa argamassadora. i, intestino. j, vagina externa. $\mathrm{k}$, duto uteri no comum. 1 , vesícula seminal principal. $\mathrm{m}$, vesícula seminal accessória. n, duto ejaculatório. ne, comissura nervosa. o, bainha do penis. od, oviduto. ov, ovários. p, estilete penial. pi, pigmento sub-cutâneo. q, duto da secreção granulosa. $\mathrm{r}$, vesículá granulorum. $\mathrm{s}$, esfíncteres. $\mathrm{sp}$, espermatozóides no oviduto. $\mathrm{t}$, dobra do átrio masculino. te, testículos. $\mathrm{u}$, útero. $\mathrm{v}$, olhos ventrais. $\mathrm{w}$, sulco sensorial. $\mathrm{x}$, ventosa. $\mathrm{y}$, poros masculinos. $\mathrm{z}$, poro feminino. 


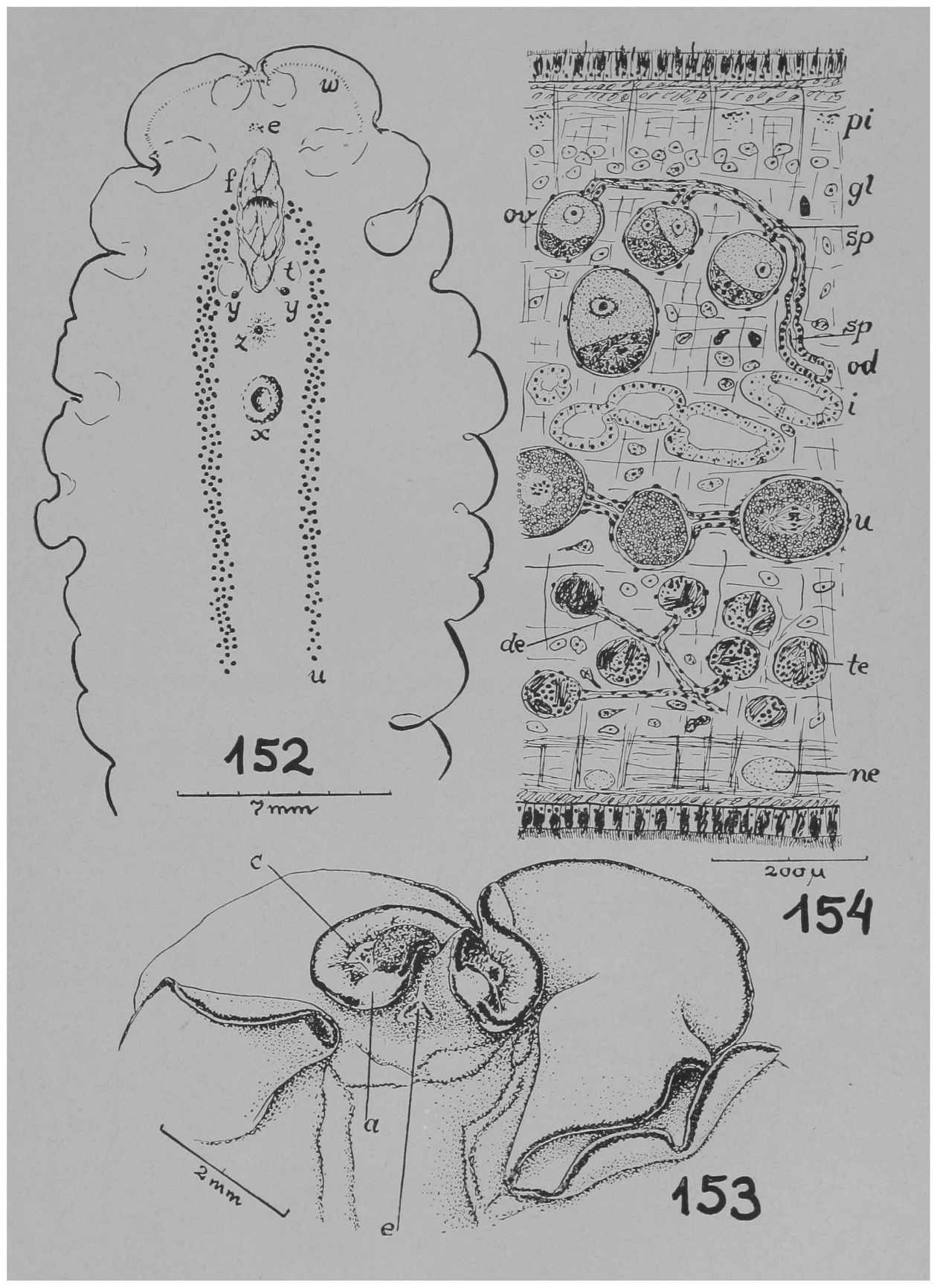




\section{ESTAMPA XXIX}

Pseudoceros evelinæ, sp. $\mathrm{n}$.

(Também Estampa XXVIII, Figs. 152-154)

Letras veja Estampa XXVIII

Fig. 155 - Tentáculos com os olhos, em vista dorsal. Preparação em óleo de cravo.

Fig. 156 - Tentáculos e sulco sensorial ; vista ventral.

Fig. 157 - Corte combinado dos órgãos copulatórios ; dos dois aparelhos masculinos somente um foi desenhado. 
E. MARCUS - TURBELLARIA BRASILEIROS (8) ESTAMPA XXIX

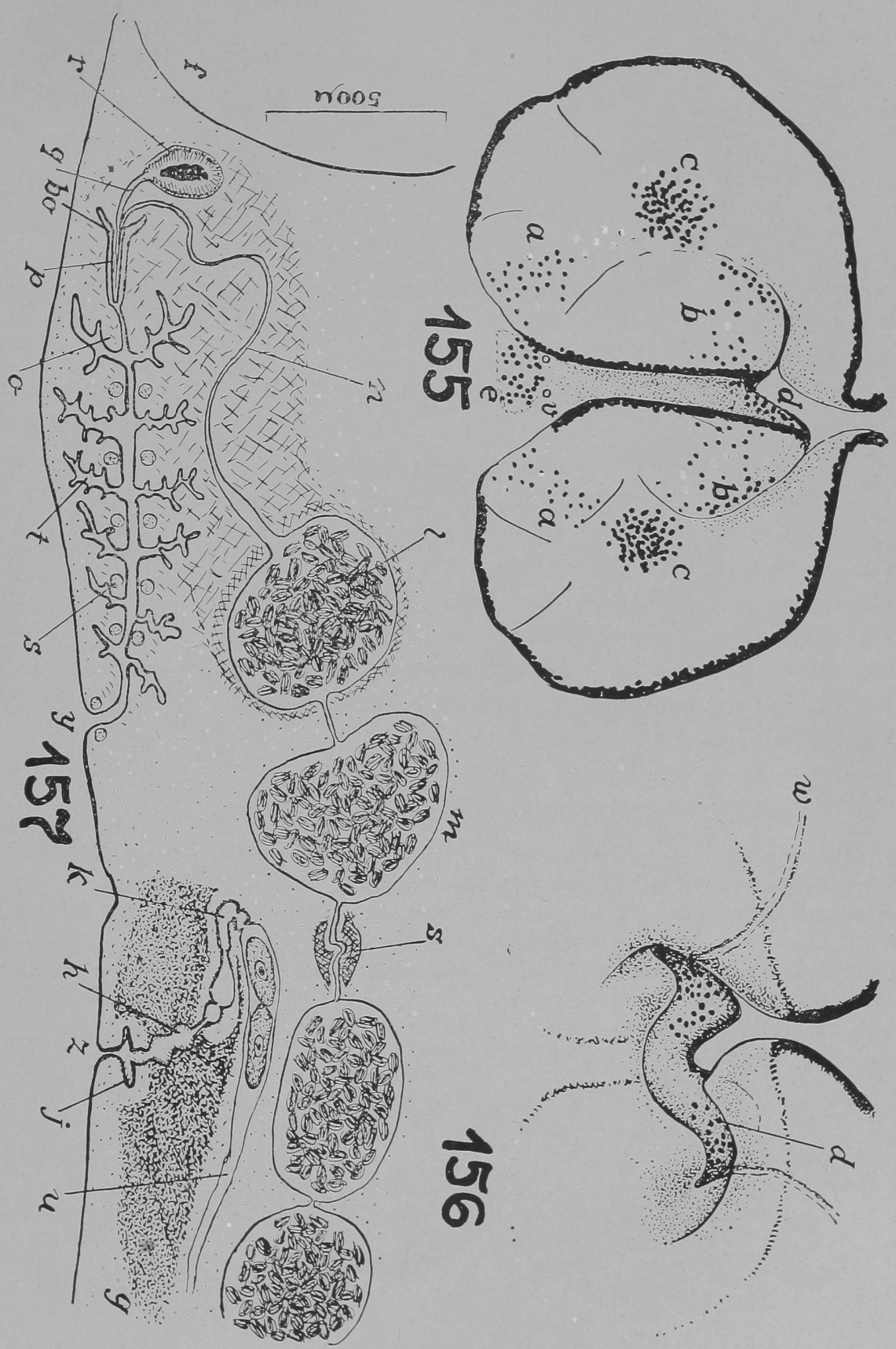




\section{ESTAMPA XXX}

Cycloporus gabriellæ, sp. n.

(Também Estampa XXXI, Fig. 166)

Fig. 158 - Animal vivente ; vista dorsal.

Fig. 159 - Olhos desenhados com o prisma de projeção.

Fig. 160 - Corte mediano, combinado, da extremidade anterior.

Fig. 161 - Corte transversal de uma vesícula intestinal estendida.

Fig. 162 - Corte transversal de uma vesícula intestinal vazia.

Fig. 163 - Larva estéril ; vista do lado ventral.

Fig. 164 - Larva estéril : vista do lado esquerdo.

Fig. 165 - Verme recém-metamorfoseado, estéril ; vista ventral.

a, átrio masculino. b, bôca. c, cérebro. d, células canaliculadas. e, células musculares. f, faringe. g, glândulas argamassadoras. $h$, nervos longitudinais. i, ramo intestinal ântero-mediano. $\mathrm{j}$, intestino principal. $\mathrm{k}$, divertículo intestinal lateral. l, ovogônia. m, gânglios pré-cerebrais. n, olhos cerebrais. o, olhos tentaculares. p, poro masculino. $q$, poro feminino. $r$, vesícula granulorum. $s$, vesícula seminal. $t$, célula oclusora. u, duto uterino comum. v, bolsa das glândulas argamassadoras. w, duto ejaculatório. $\mathrm{x}$, papila penial. $\mathrm{y}$, bolsa penial. $\mathrm{z}$, bainha do penis. 


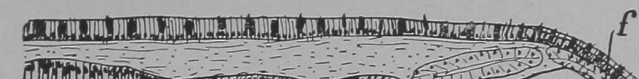

\section{0}

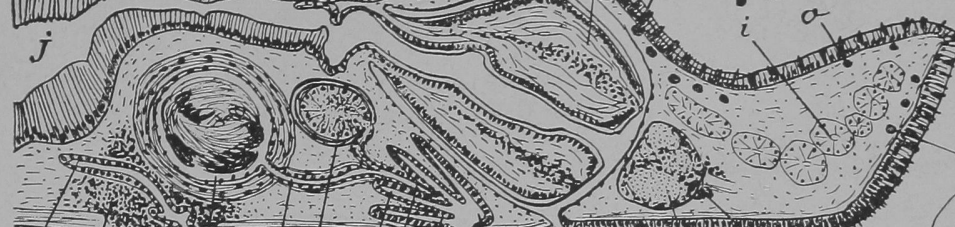

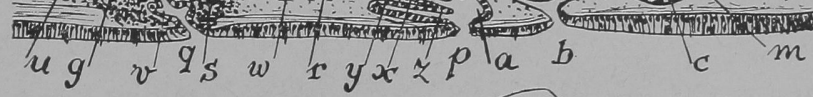
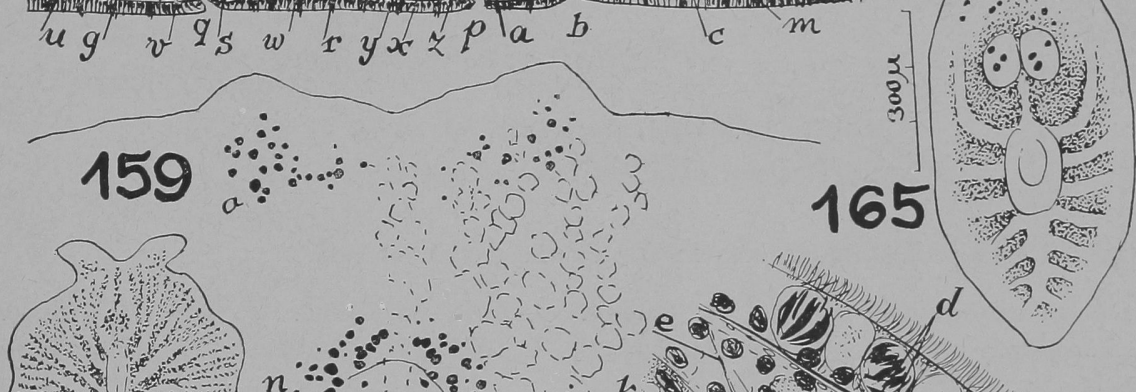

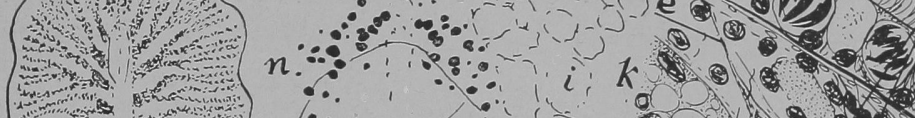
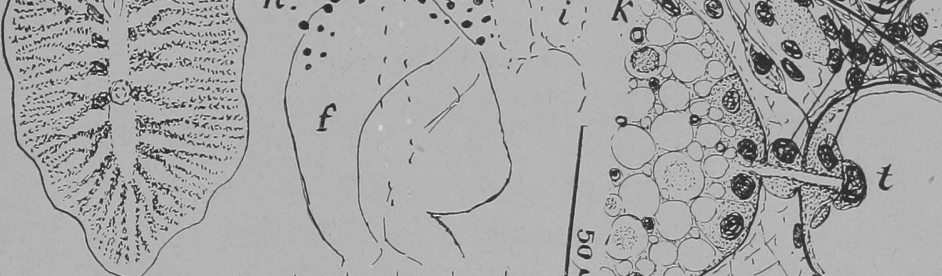

158

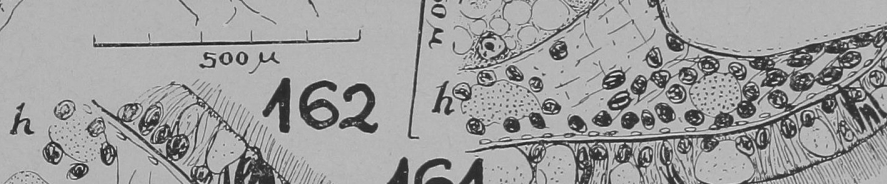
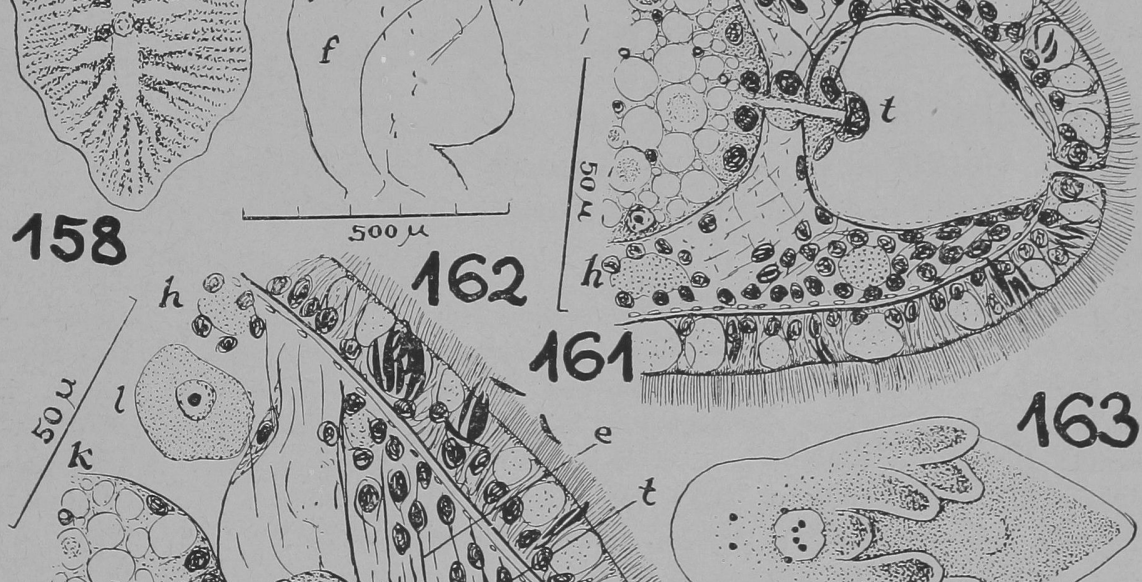

ari
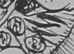

163

h........

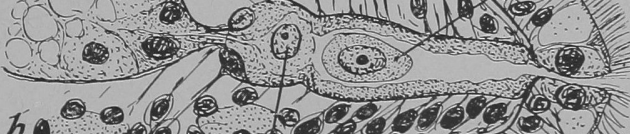

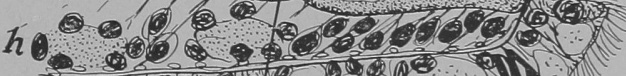

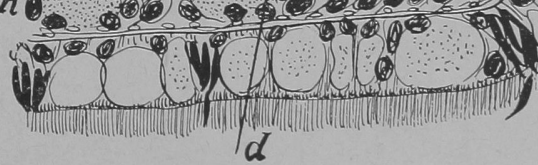

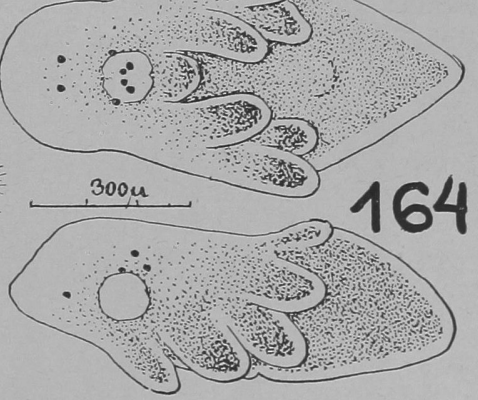




\section{ESTAMPA XXXI}

Cycloporus gabriellæ, sp. n.

(Também Estampa XXX, Figs. 158-165)

Fig. 166 - Corte mediano, combinado, de uma larva sexuada.

a, bolsa da faringe. b, bôca. c, cérebro. d, átrio masculino. e, ôlho. f, faringe. $\mathrm{i}$, intestino. $\mathrm{p}$, penis. $\mathrm{s}$, vesícula seminal. $\mathrm{t}$, testículos. $\mathrm{v}$, ventosa. $\mathrm{z}$, bainha do penis.

\section{Prosthiostomum matarazzoi, sp. n.}

(Também Estampa XXXII, Fig. 171 ; Estampa XXXIV. Fig. 181)

Fig. 167 - Extremidade anterior ; desenho com o prisma de projeção.

Fig. 168 - Vista ventral do aparêlho copulatório de um verme de $8 \mathrm{~mm}$.

Fig. 169 - Corte mediano da região entre faringe e ventosa.

Fig. 170 - Estilete.

a, átrio masculino. b, bolsa faríngea. c, cérebro com os olhos cerebrais. d, duto eferente. e, duto ejaculatório. f, faringe. g, glândulas argamassadoras. h, diafragma do intestino principal. $\mathrm{i}$, intestino principal. $\mathrm{j}$, intestino terminal. $\mathrm{k}$, ventosa. $\mathrm{l}$, bolsa do penis. mi, células claviformes de Minot. p, estilete penial. q, vesícula granulorum. r, vesículas accessórias. $\mathrm{s}$, vesícula seminal. sr, sulco sensorial. $t$, poro masculino. u, poro feminino. $\mathrm{v}$, bolsa das glândulas argamassadoras. $\mathrm{w}$, duto uterino comum. $\mathrm{x}$, útero. $\mathrm{y}$, olhos ventrais. $\mathrm{z}$, olhos marginais. 


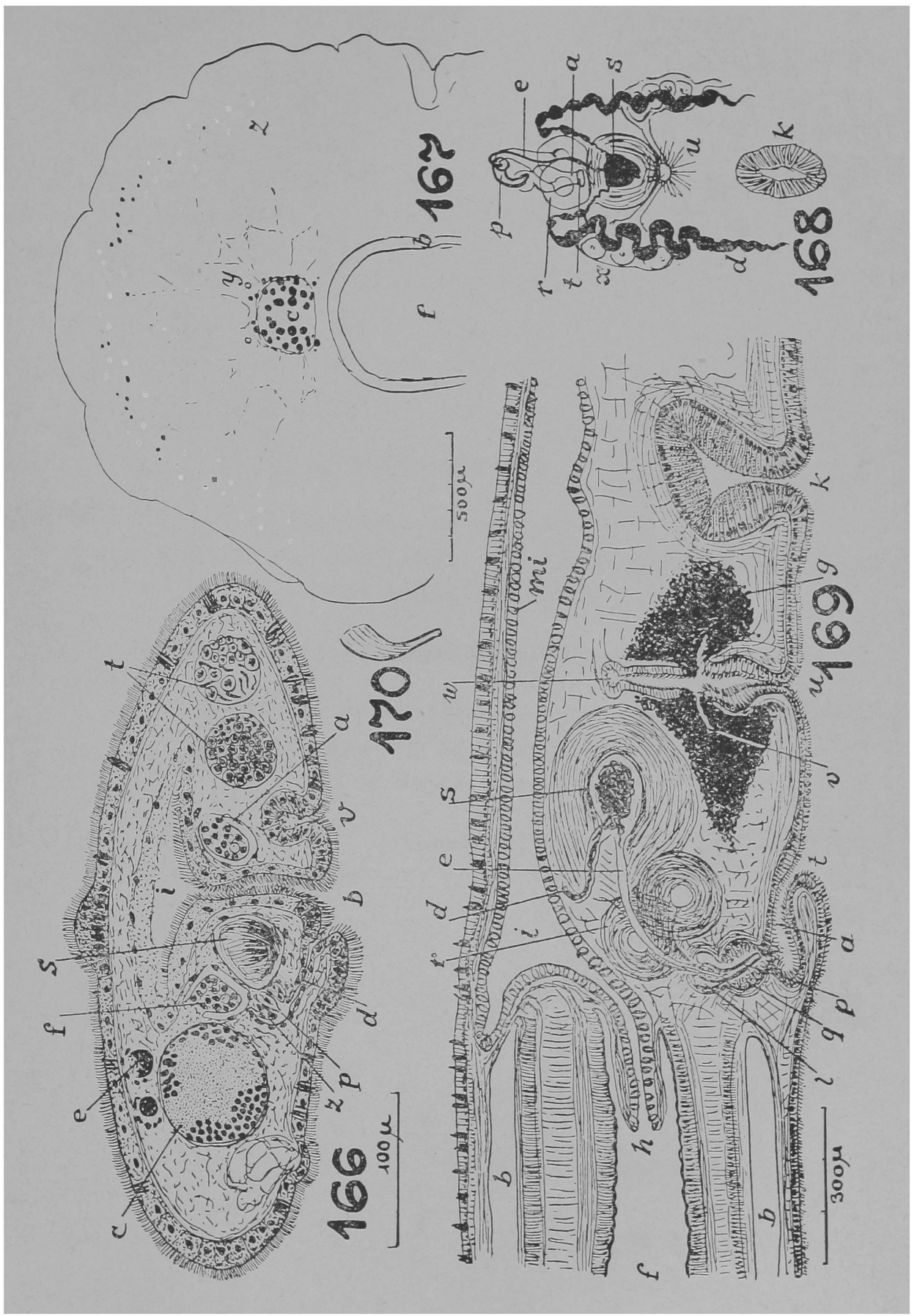


Prosthiostomum matarazzoi, sp. n.

(Também Estampa XXXI, Figs. 167-170 ; Estampa XXXIV, Fig. 181)

Letras veja Estampa XXXI

Fig. 171 - Verme total, de $12 \mathrm{~mm}$., ao comprido, em estado conservado.

Prosthiostomum gilvum, sp. n.

(Também Estampa XXXIII, Figs. 174-175)

Letras veja Estampa XXXIII

Fig. 172 - Vista total do verme em bálsamo.

Fig. 173 - Extremidade anterior ; desenho com o prisma de projeção. 
E. MARCUS - TURBELLARIA BRASILEIROS (8) ESTAMPA XXXII

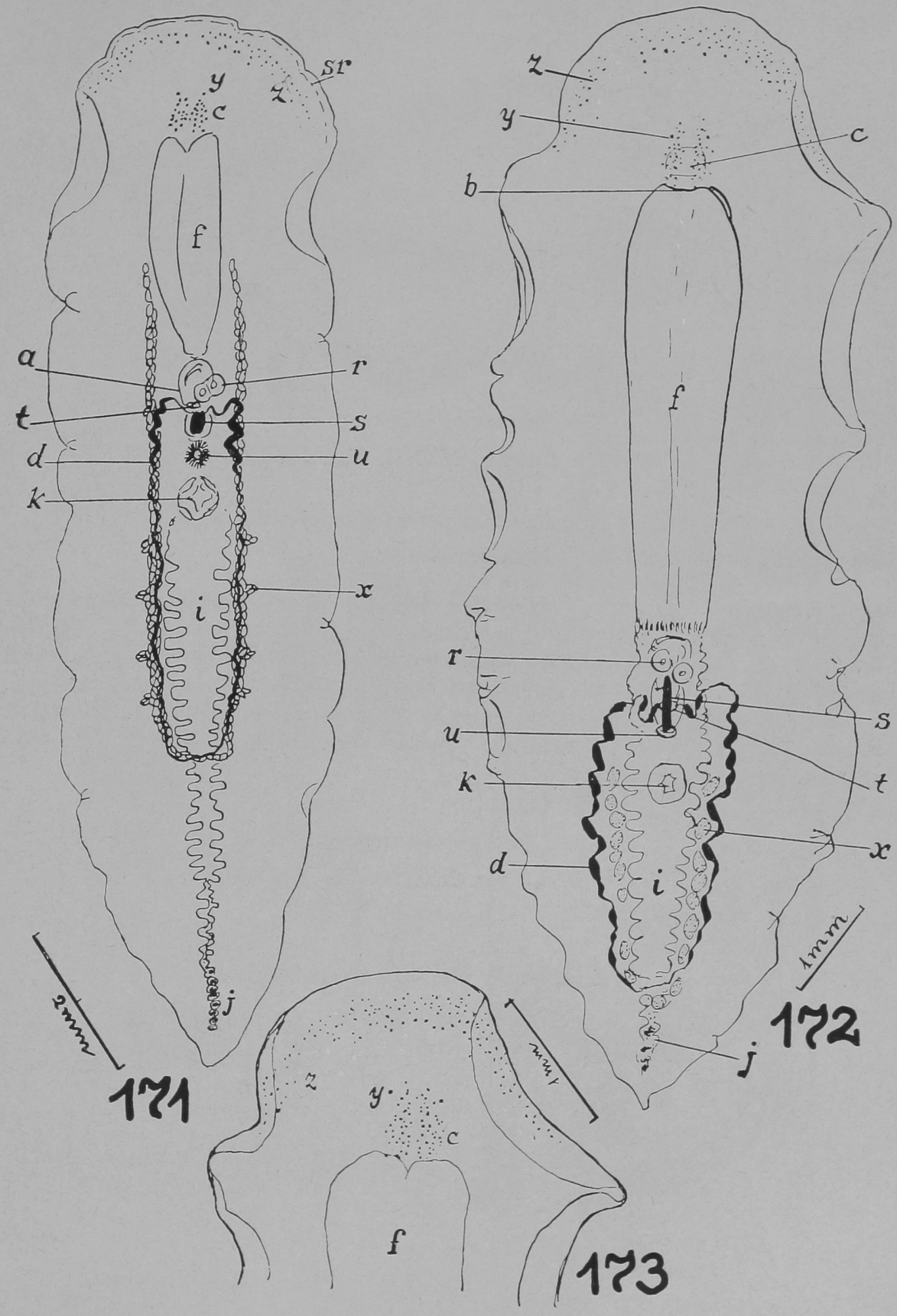




\section{ESTAMPA XXXIII}

Prosthiostomum gilvum, sp. n.

(Também Estampa XXXII, Figs. 172-173)

Fig. 174 - Corte mediano, combinado, dos órgãos copulatórios.

Fig. 175 - Vista ventral dos órgãos copulatórios.

a, átrio masculino. c, cérebro com os olhos cerebrais. d, duto eferente. e, duto ejaculatório. f, faringe. g, glândulas argamassadoras. i, intestino principal. j, intestino terminal. $\mathrm{k}$, ventosa. $\mathrm{l}$, bolsa do penis. m, células claviformes de Minot. $\mathrm{n}$, canal genital feminino. o, glândulas grânulo-secretoras. p, estilete. q, vesícula granúlorum. $\mathrm{r}$, vesículas accessórias. $\mathrm{s}$, vesícula seminal. $\mathrm{t}$, poro masculino. $\mathrm{u}$, poro feminino. $\mathrm{v}$, bolsa das glândulas argamassadoras. w, duto uterino comum. $\mathrm{x}$, útero. $\mathrm{y}$, olhos ventrais. $z$, olhos marginais.

Prosthiostomum cynarium, sp. n.

(Também Estampa XXXIV. Figs. 177-180)

Letras veja Estampa XXXIV

Fig. 176 - Corte mediano, combinado, dos órgãos copulatórios. 
E. MARCUS - TURBELLARIA BRASILEIROS (8) ESTAMPA XXXIII
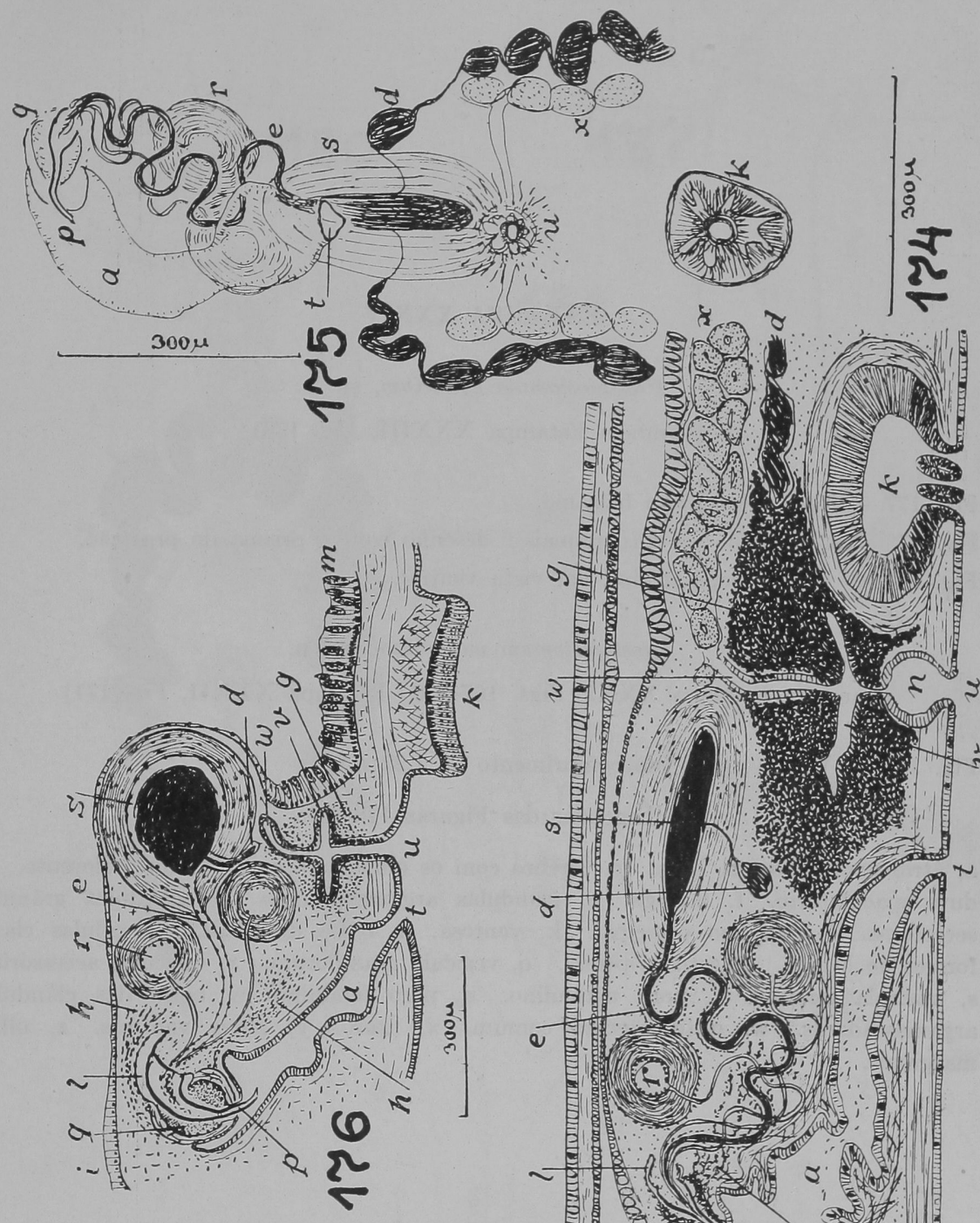

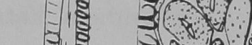

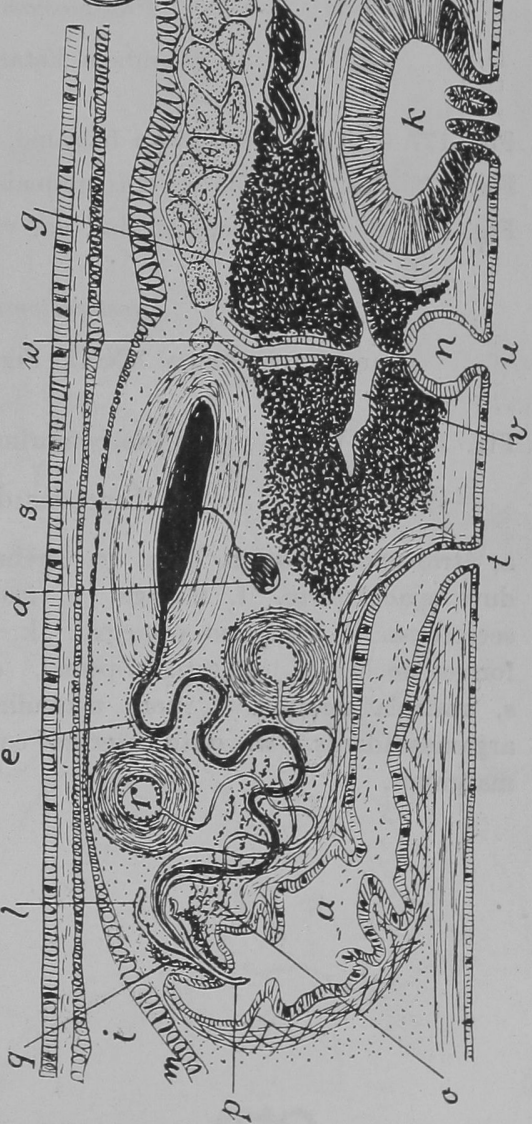




\section{ESTAMPA XXXIV \\ Prosthiostomum cynarium, sp. n. \\ (Também Estampa XXXIII, Fig. 176)}

Fig. 177 - Verme total, em bálsamo.

Fig. 178-179 - Olhos de dois animais; desenho com o prisma de projeção.

Fig. 180 - Órgãos copulatórios, em vista ventral.

Prosthiostomum matarazzoi, sp. n.

(Também Estampa XXXI, Figs. 167-170 ; Estampa XXXII, Fig. 171)

Fig. 181 - Verme jovem, de comprimento de $1,22 \mathrm{~mm}$.

Legendas das Figuras 176-181:

a, átrio masculino. b, bôca. c, cérebro com os olhos cerebrais. d, duto eferente. e, duto ejaculatório. f, faringe. g, glândulas argamassadoras. h, glândulas grânulosecretoras. $\mathrm{i}$, intestino principal. $\mathrm{k}$, ventosa. $\mathrm{l}$, bolsa do penis. $\mathrm{m}$, células claviformes de Minot. p, estilete penial. q, vesícula granulorum. r, vesículas accessórias. $\mathrm{s}$, vesícula seminal. $\mathrm{t}$, poro masculino. $\mathrm{u}$, poro feminino. $\mathrm{v}$, bolsa das glândulas argamassadoras. $\mathrm{w}$, duto uterino comum. $\mathrm{x}$, útero. $\mathrm{y}$, olhos ventrais. $\mathrm{z}$, olhos marginais. 
E. MARCUS - TURBELLARIA BRASILEIROS (8) ESTAMPA XXXIV

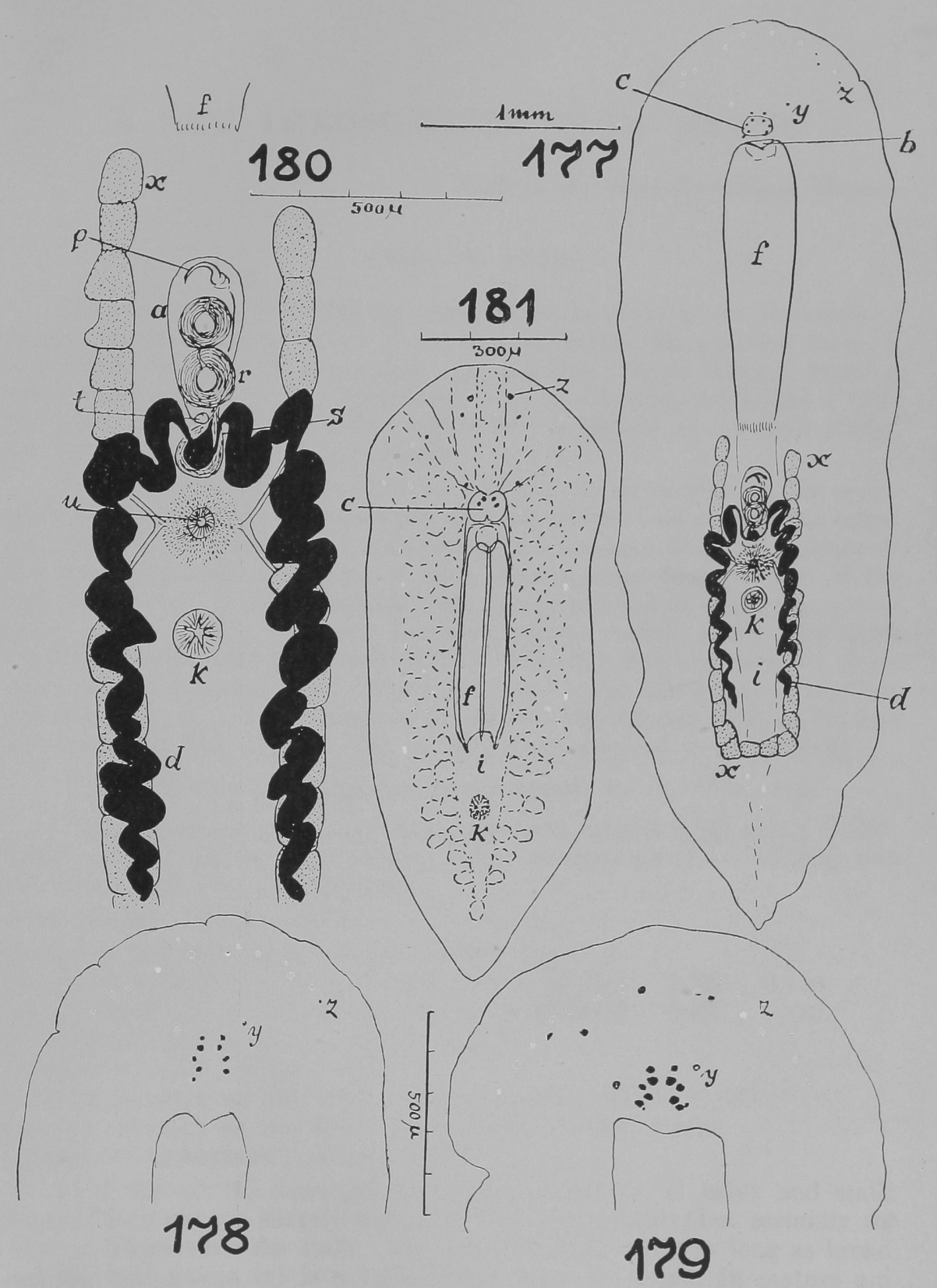


